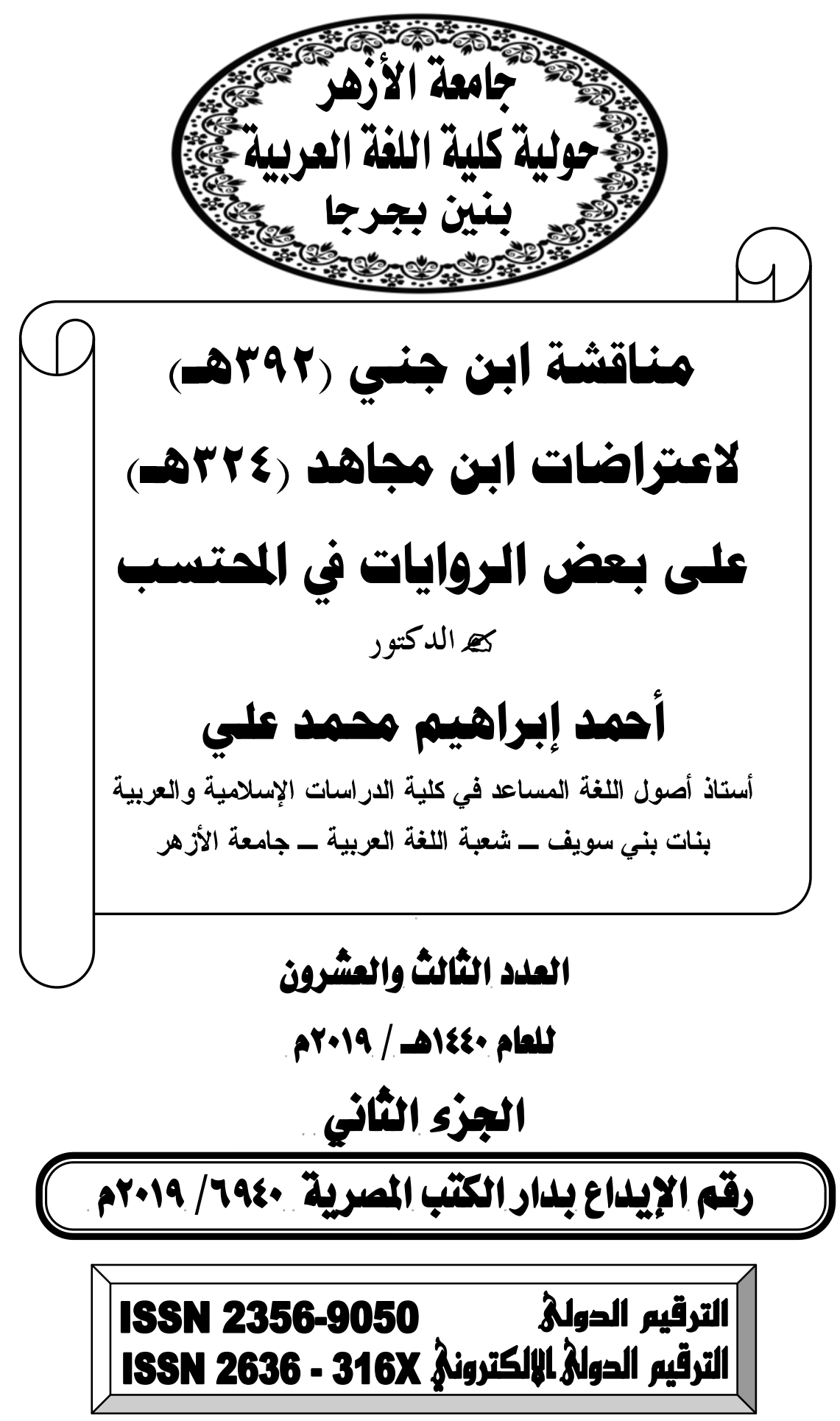


مناقشة ابن جني (بrara)

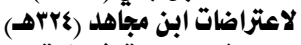

على بعض الروايات في المحتسب الماتب

\section{هذص البمث}

هناقشة ابن جنبي (rarar) لاعتراضات ابن هجاهد (\&r)

\section{على بهض الروايات في المتسبب}

وعليه فقد كان كتاب " المحتسب لابن جنى "و "السبعه فى القراعات "

لابن مجاهد هما المصدران اللذان اجريت عليهما خطوات الار اسة

وقد جاء اختياري لهذا البحث لثراء مؤلفات "(بن جنى " كلها بالعديـــ

من المسائل اللغوية على اختلافها الصوتية والصرفية والنحوية و الدلالية

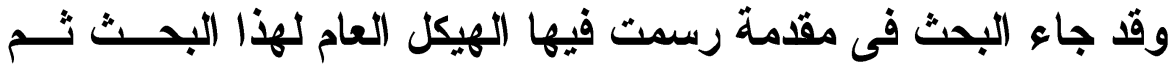

تمهيد عرفت فيه بصاحبى المصدر وهما : ابن مجاهد ( צr rهـــ وابـن

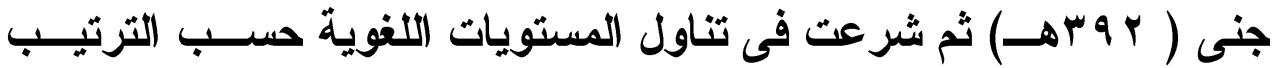
المشار اليه : الصوتى ثم الصرفي ثم النحوي ثم الدلالي على أن يكون المنهج المتبع فى الار اسة انما هو المسـنهج الوصــى الأي يقوم على الوصف والتحليل - أما عن الصعوبات التى رافقت الباحث على مدار مر احل هـــذه الار اســة فلعلها تتحصر فى تثابك وتتلاخل خيوط الدر اسة نظر التقوق (ابن جنى ) فى وجوه اللغة كلها وتفوقه فى علوم اللغة والنحو والصرف والأدب فقد كان اماما فى كل هذه العلوم .فلا تكاد تظقر بمسالة من المسائل إلا وهو

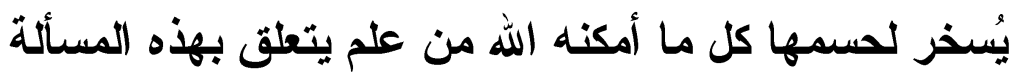
- هذا ، وبعد أن امتن الله عز وجل على بتجاوز مراحل الار اســـة تمكـنـ البحث من استعر اض جملة من التتائج والتوصيات تمخض عنها البحــث

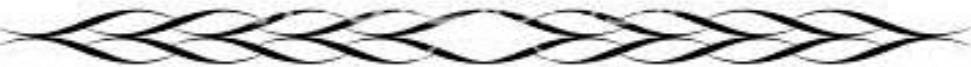




\section{الترقير الدولخ \\ ISSN 2356-9050}

ا - أن نقاط الخلاف بين ابن مجاهد وابن جنى ممثلة فى كل المستويات اللغوية وأن هذا الخلاف لم يكن عبثا وإنما كان له أصل عند اللغويين وأنهما لم يختلفا فى كل شئ بل أصابا قرا كبيرا من الموافقة ليعد فى طليعة المفاهيم الزاهرة r- أيضا تقوق "ابن جنى " على ابن مجاهد فى مواققة الأول لمذاهب اللغويين والنحاة بل وتفوقه فى مدى الأسجام الأي واقث كل آراء ابن جنى الصوتية وعلى مستوى كل مؤلفاته ـ الأمر الأي دفع ابن جنى الى التقليل من الشأن والاستهانة فى بعض الأحيان بآراء ابن مجاهد بل ربما زاد هذا التندر حتى وصل الى مرتبة التعريض r- ومنها ما ترتب على ما سبث من تفوق ابن جنى على ابن مجاهد فى كثير من وجوه المقارنة فقد تفوق عليه صوتيا وصرفيا ودلاليا ـ وعلى مستوى العلوم الثرعية وكثرة الثواهد عند ابن جنى ع - كا لاحظت الار اسة أن ابن جنى لم يكن دأبه فقط الاتتصار لمذهبه من ابن مجاهد بل ربما صَوب رأيه فى بعض الأحيان بل ربما استعان به لترجيح قراعة على أخرى أو اتتصار المذهب على آخر لا سيما وقا رصد البحث بعض الحالات القليلة التى أصاب فيها ابن مجاهد الجادة وسدة الصواب. roor res

\section{أحمد إبزاهيهم همهمد عأهي}

أستاذ أصول اللغة المساعد

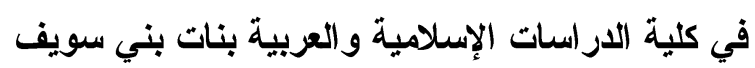

شعبة اللغة العربية ـ جامعة الأزهر

\section{0}



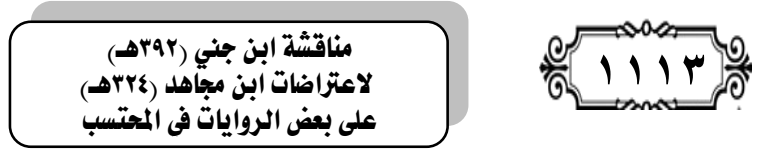

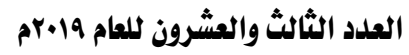

الجزء الثاني

\section{Research Summary}

Ibn Jenny's discussion (died in 392 A.H)

of the objections of Ibn Mojahed, who died in the year " 324 AH," to some of the narrations in In Ibn Jenny's book "Al-Muhtasib"

Thus, "Muhtasib" Ibn Jenny's book " and "Al-Sabaa 'in the Recitations" by Ibn Mujahid were the two sources on which the study has depended on

In my choice for this research is to enrich the works of Ibn Jenny in a variety of linguistic, phonetics, grammatical and semantic issues.

The research came in an introduction in which the structure of the work of this research was written and then a preface in which the author of the source is known as Ibn Mojahed $324 \mathrm{AH}$ and Ibn Jenny (392 AH). Then I started to address the linguistic levels in the order referred to as the phonetic and morphological, then grammatical and semantic

The method used in the study it is the descriptive approach, which is based on the description and analysis

-As for the difficulties that accompanied the researcher throughout the stages of this study, it may be confined to the intertwining and overlap of the threads of the study because of the superiority of "Ibn Jenny " in the faces of the language and its superiority in the sciences of language, grammar, literature and literature has been Imam in all these ills. Only he mocks to resolve all that God can of knowledge concerning this matter

*This after the gratitude of God Almighty to overcome the stages of study enables the search to review a set of conclusions and recommendations emerged from the research

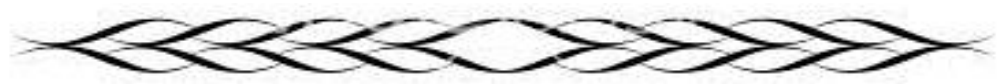


الترقير الدولخ

ISSN 2356-9050

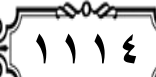

$111 \varepsilon$
حولية كلية اللفة العربية بجرجا

مجلة علمية مجكمة

* The points of disagreement between Ibn Mojahed and Ibn Jenny are represented at all linguistic levels and that all this dispute was not in vain, but it had an origin among the linguists and that they did not differ in everything, but a great deal of agreement to be considered in forefront of bright concepts .

*Ibn Jenny also surpassed the Ibn Mojahed in the first approval of the doctrines of the linguists and the prophetic, and even surpassed in the extent of harmony, which agreed all the views of Ibn Jenny voice and the level of all his writings. Which led Ibn Jannah to Tindarfi inference sometimes in the views of Ibn Mojahed, but perhaps increased this trickery even reached the level of exposure

*including the result of the above superiority of the Ibn Jenny on the Ibn Mojahed in many aspects of the comparison has surpassed him voice, exchange and delusion. And the level of forensic sciences and the abundance of evidence at Ibn Jenny

Ibn Jenny as the study has noticed didn't aim at only defending his dectorine against Ibn Mojahed - but he may have corrected his opinion . Sometimes he also may have used Ibn Mojahed's opinion to prefer recitation to another or to defend adectorine against another - particularly the research monitored some a few cases in which Ibn Mojahed was completely right.

Dr

\section{Ahmed Ibrahim Mohamed Ali}

Professor of Assistant Language In the Faculty of Islamic and Arabic Studies Beni Suef Girls Arabic Language Division 
مناقشة ابن جني (بrara)

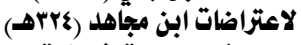

على بعض الروايات في الماتهتب مئب
की 11110 ,

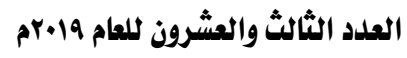
الجزء الثاني

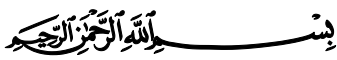

الاقدمهة:

بسم الله ، والحمد الله ، والصلاة والسلام على رسول الله ، وبعد ..... فقد عالج هذا البحث قضايا متشابكة جدا من قضايا البحث اللغـوى ، تثابكت فيها جميع وجوه اللغة : الصــوتية ، والصــرفية ، والمعجميـة ، والنحوية ، والالالية ، إثر مواجهة مباركة بين علم من أعــلام اللغــة فـى

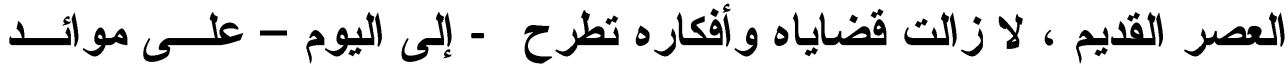
اللغويين ، غزت أفكاره الصوتية والصرفية كل العصور ، وليس لباحث مــن عذر فى إهمال أفكاره ، التى أودعها مؤلقاته ، لا ســميا ( ســر صــناعة الإعراب ) و ( الخصائص ) فضلا عن صحبة المتنبى لله ، وثنائــهـه عليـهاه ،

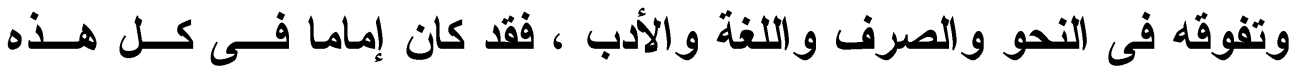
العلوم، ألا وهو ابن جنى .

وبين علم آخر من أعلام القزراعات القرآنية ، بما تحويــهـ مــن زخــ اللهجات العربية وخصائصها، ألا وهو أبو بكر بن مجاهد ، وقد طقق ابــن جني - في كتابه ( (المحتسب) - يتعقب اعتر اضات ابن مجاهد - في كتابه ( السبعة في القراعات) - على بعض القراعات ، وقد أسفر هذا التعقب عن

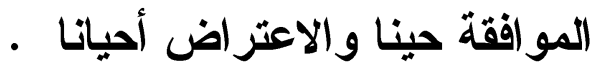
ومما راق لى فى هذه المصدر - المحتسب - أن ابن جنى كان يسوق اعثر اض ابن مجاهد ، فى مسألة بعينها سوقا صريحا ، وربمــا دون أدنــى تصرف فى هذا السوق ، ثم يتولى بعد ذلك - وبدقة فائقة - مســألة الــرد على ابن مجاهد ، مستخدما كل ما زوده الله به من أسلحة الرده ، بـلـل مــن

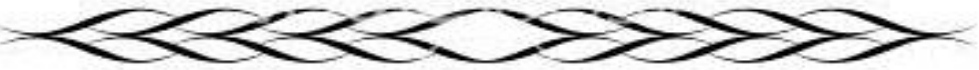




\section{الترقير الدولخ \\ ISSN 2356-9050}

أسلحة المحاورة و المفاصلة والمباراة ، الأمر الذى عاد ببالغ الفائدة وعظيم

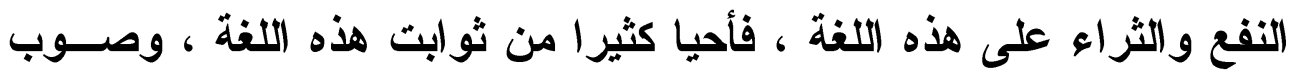

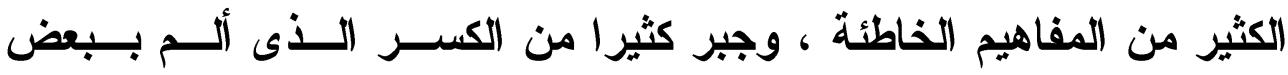

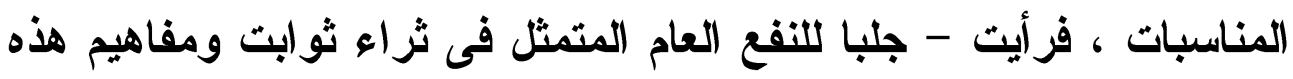

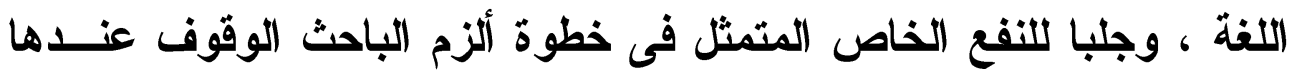

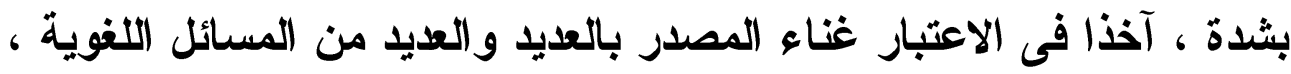

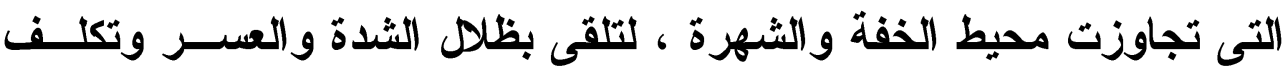

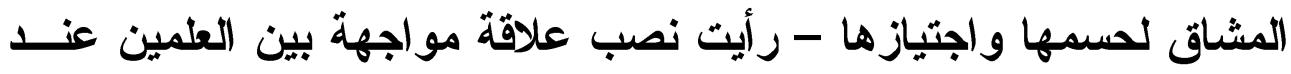
كل نقطة وقع فيها خلاف بينهما . الأمر الأى دفعى فى كثير من الأحيان إلى التواصل مع أساتذة أصول

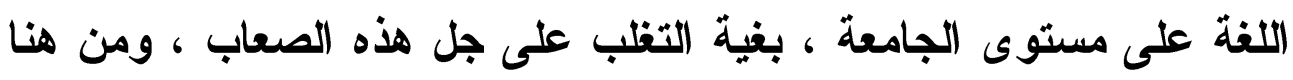

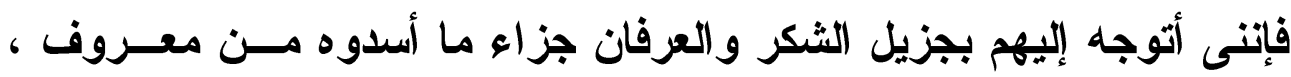
ونصح لحسم هذا النزاع .

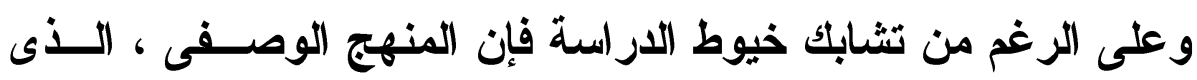

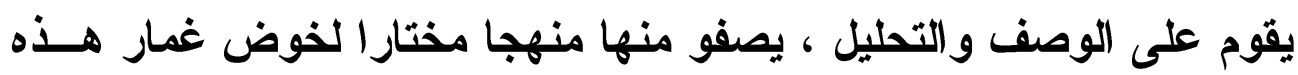

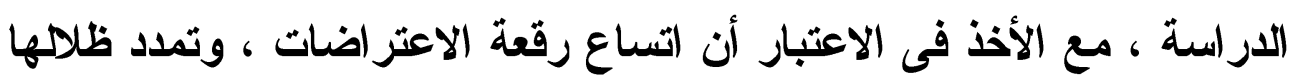

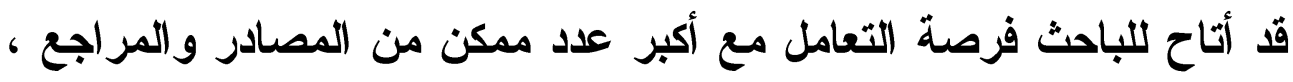

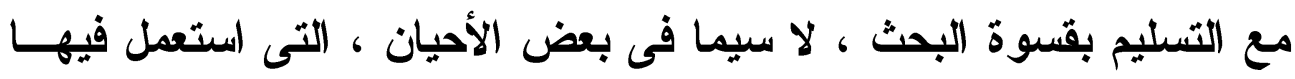

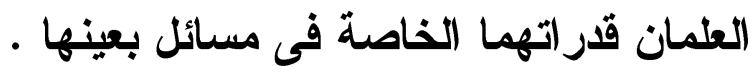

وتيسير المهمة المتلقى فقد آثرت الجمع بين المتثابهات فـى مكــان

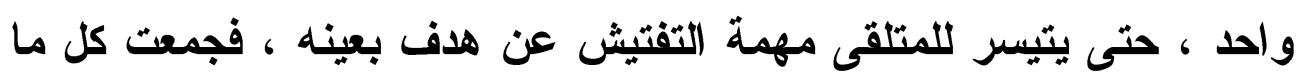

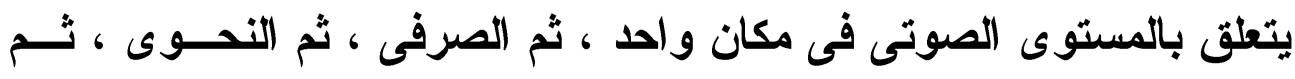

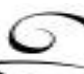




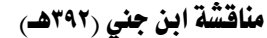

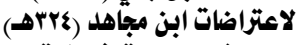

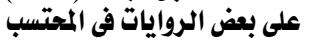

الدلالى ، وينفس الترتيب كما هو متفق عليه عند اللغويين ـ مع رصد الآية التى احتضنت الكلمة موضع البحث و التفتيش .

هذا ، وقد وقف البحث عند كثير من الآراء التي نسبها (بن جني لابن

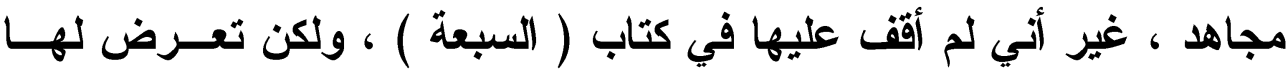
البحث شأنها شأن سائر القراءات إثراء للمفاهيم اللغوية

وعليه ، فقد جاء البحث فى مقدمة ، رسمت فيها الهيكل العـام لهـــا البحث ، ثم تمهيد عرفت فيه بعلمى المصدر : (بن مجاهد ( ت ع ع ) و وابن جنى ( ت ب r r ) ، ثم شرعت فى تناول المستويات اللغوية حسب الترتيـب المشار إليه : الصوتى ثم الصرفى ثم النحوى ثم الالالى . كما راعيت - وعند ذكر النتائج والتوجيهات التى تمخض عنها البحث

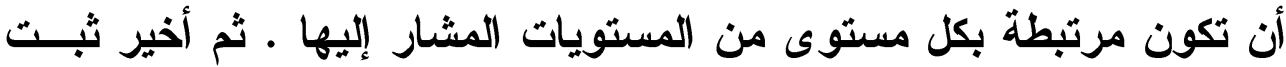

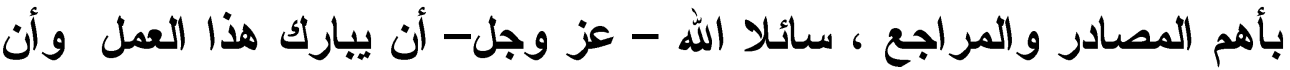

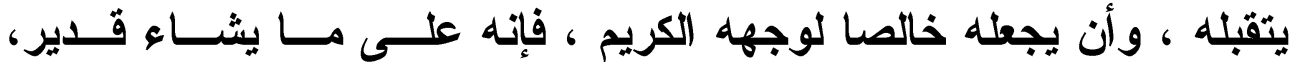

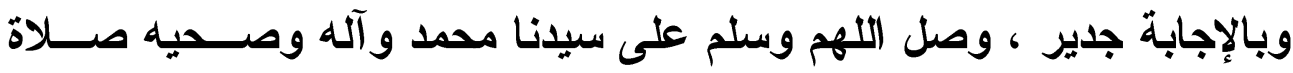
وسلاما دائمين متلازمين إلى يوم الدين .

\section{الباحث}

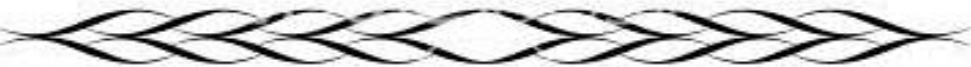




\section{الترقيه الدولم \\ ISSN 2356-9050}

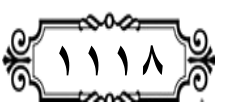

\section{التمهميد}

\section{ابن هماهد وابن جنى}

ويجدر بى - فيه - أن أعرف القارئ بعلى هذا البحث ، ومن جـرث

بينهما فصول المحاورة.

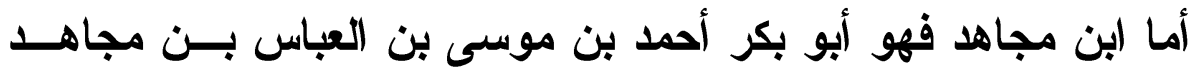

التميمي البغدادي الإمام القرئ المحدث النحوى ، شيخ المقرئين ، مصــف كتاب (السبعة) ولا سنة خمس وأربعين ومــائتين ، وتــوفى ســنة أربــع وعشرين وثلاث مائة ، سمع من سعد بن نصر، و الرمادى ، وطبقتهم ، وتلا على قتبل وأبى الززعراء بن عبدوس ، وانتهى إليه علم هذا الشأن ، وتصدر مدة .

قرأ عليه عبدالواحد بن أبى هاثم ، وأبو عيسى بكار ، وأبــو الفــرج الثنبوذى ، وحدث عنه (بن شاهين والدارقطنى ، وأبو بكر شــاذان ، قــال أبوعمرو الدانى : " فاق ابن مجاهد سائر نظائره مع اتساع علمه وبراعــة فهمه، وصدق لهجته ، وظهور نسكه ، وتصدر فى حياة محمد بـن يحيـى • الكسائى

أقبل على حفظ القراعات ، وطلب العلوم اللغوية والثرعية منذ نعومة أظفاره ، كما أقبل على أساتذة النحو الكوفيين يأخذ ما عندهم ، وكما أكـبـ على دراسة الحديث النبوى ، ومعرفة الآثار ، أكب إكبابا منقطع النظير على قر اعة القرآن ، وتفسيره ومعانيه و إعر ابه ، وروايات حروفه ، وطرقها . 


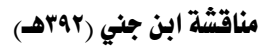

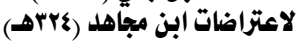

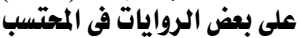

وكان لا يغضب ولا يسخط إلا فى رضا الله ، وتأمل موقفه مع الحلاج

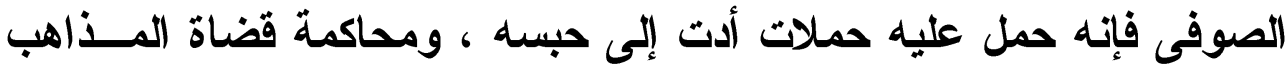

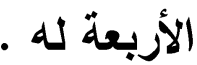

وأهم من ذلك موقفه من ابن شنبوذ ، الأى كان يعتمد شواذ القراعات،

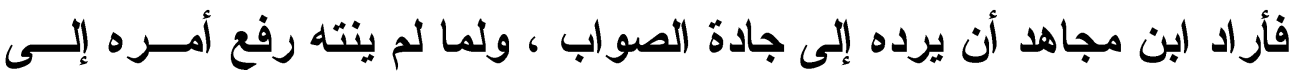
مقلة الوزير ، وضرب بالأسواط ، وحبس حتى أعلن توبته . وبتلك المواقف لابن مجاهد يكون قد وضع أصلين أساسيين فى قبــول

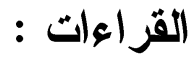
الأصل الأول : أن تكون مطابقة لخط المصحف العثمانى.

الأصل الثانى : أن تكون صحيحة السند ، وسنر اه فقى كتابه ( السبعة) يرد بعض القراعات المروية لأنها لا توافق العربية ، وبذلك يكون قد وضــع

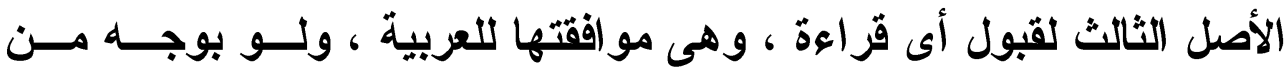

الوجوه (1) - (الاهل

وبعد أن استخلص ابن مجاهد للأمة سبع قراعات ، ألف فيما وراءهــا من قر اءات صحيحة فى كتابه فى القراعات الثاذة ، وسماه كتاب القــراءات

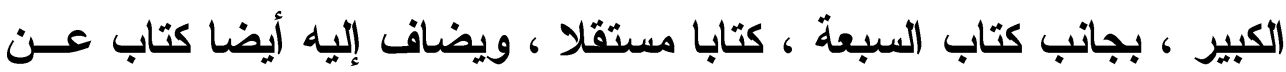

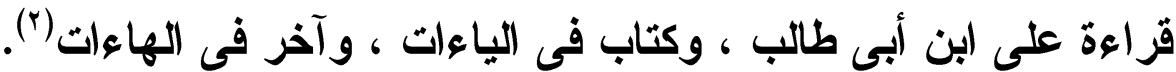

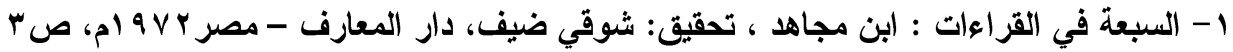

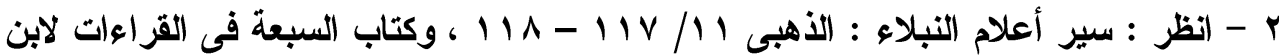

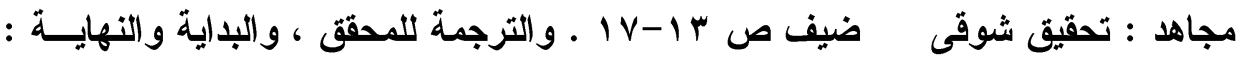

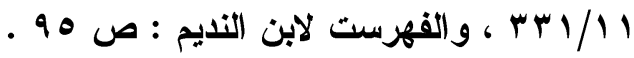




\section{الترقير الدولخ \\ ISSN 2356-9050}

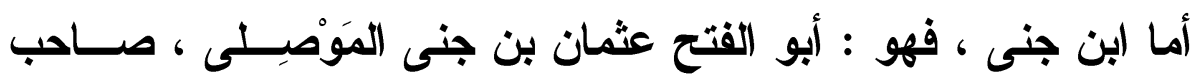

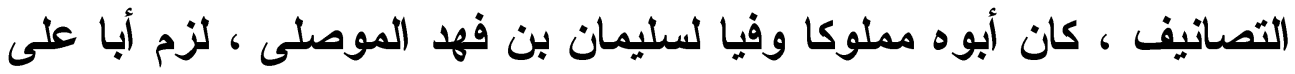

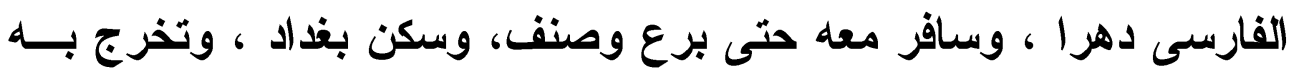

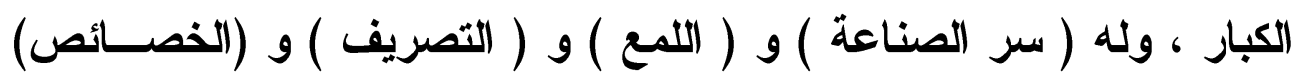

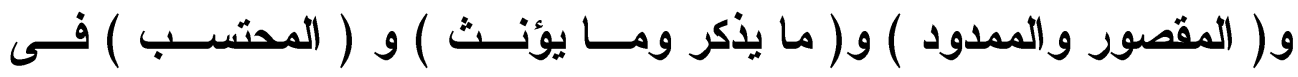

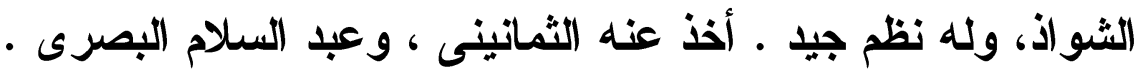

وقد صحب المتنبى واجتمع به بحلب ، وفى شيراز ، وكــان المتتبـى يجله ، ويقول فيه : " هذا رجل لا يعرف قره كثير من النــاس " . وكــان

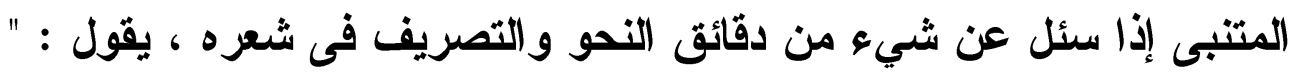

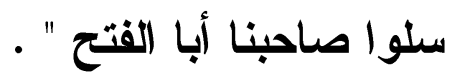
ويقول فى مسالك الأصسار : " وكان أبو الطيب المتنبى إذا سئل عـن

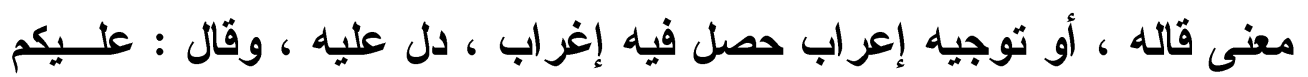

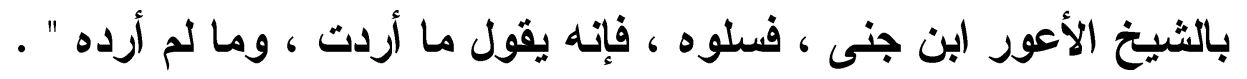
وابن جنى أول من شرح ديوان المتنبى ، وقد شرحه شرحين : الثرح الكبير ، والثرح الصغير ، والأخير هو الباقى لنا . وقد بلغ أبو الفتح فى علوم العربية الجلالة والخطر ما لـــ يبلغــه إلا في القليل ، وقث أصبح ابن جنى فى مجرى القرون بعده مضرب المثل فى معرفة النحو و التبريز فيه .

قال فيه الثعالبى فى اليتيمة : " هو القطب فى لسان العــرب ، وإليسـه

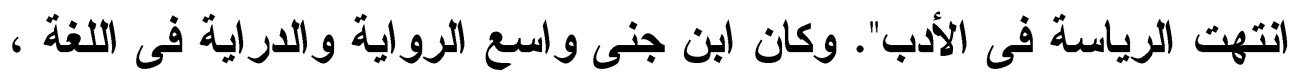

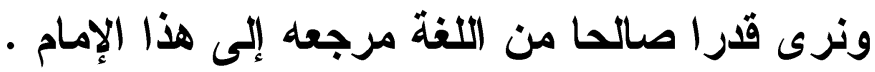


كما كان إماما فى النحو والصرف ، وهو على إمامته فيهما فى النحو

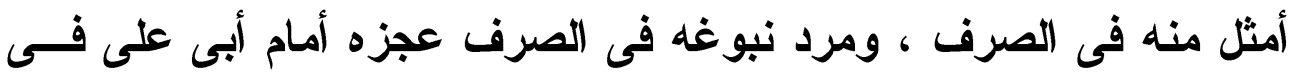

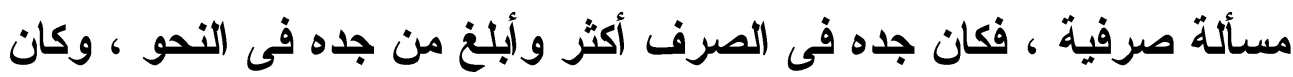

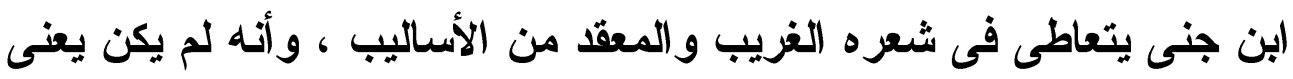

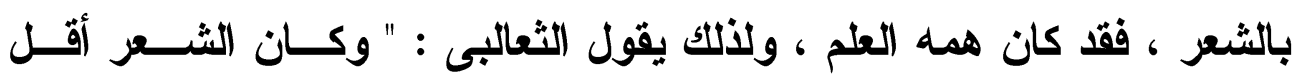

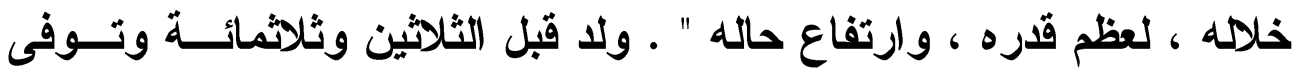

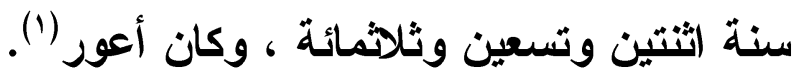

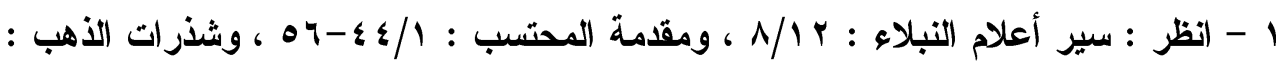




\section{الترقيم الدولم \\ ISSN 2356-9050}

\section{هستويات البحث}

كما أثثرت فى المقدمة ، وتيسير المهمة المتلقى ، فقد آتشرث تنــاول

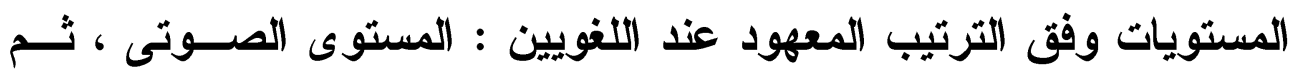

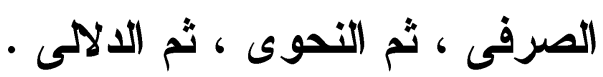

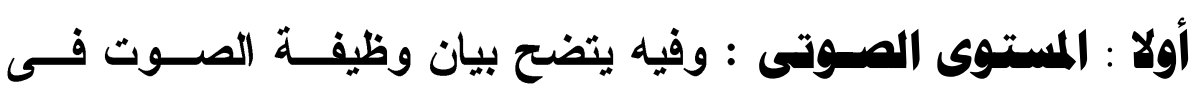

المنطوق ، بدءا بالحركات، وهى أصغر وحدة صوتية ، و وانتهاء بــالمقطع .

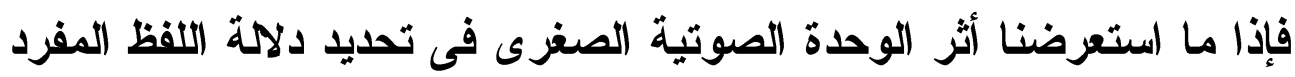

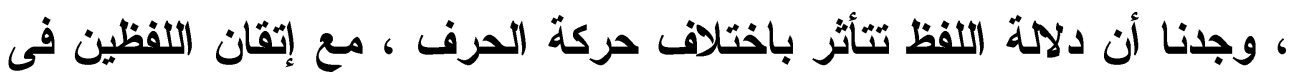
جميع الحروف .

وكذلك لو انتقلنا إلى أثز الصوت البسيط - وهو حرف واحد فى كلمــة

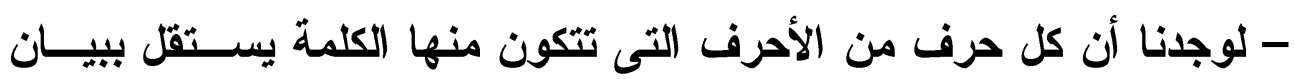
معنى خاص به ، وأن تغيره بحرف آخر يستلزم تغير دلالة الكلمة (') فضلا عن الظاهر الصوتية المعهودة :

ץ- تحقيق الهمزة وتسهيلها 1- الفتح و الإمالة

ع - التثقيل و التخفيف

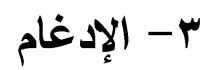

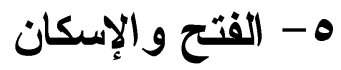
إلى آخره من سائر الظواهر الصوتية النى تمخض عنها البحث .

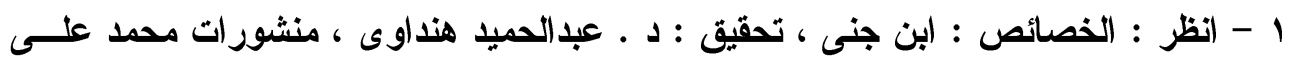

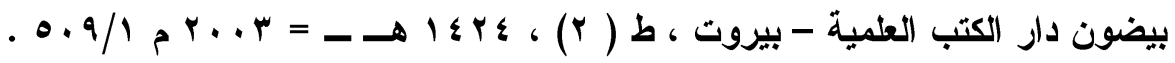

\section{0}




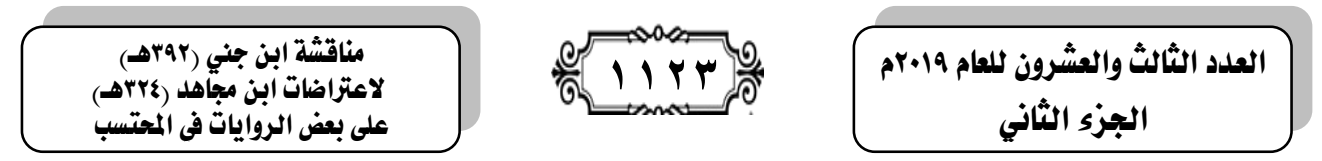

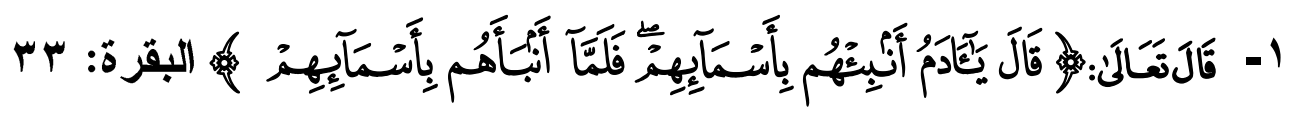

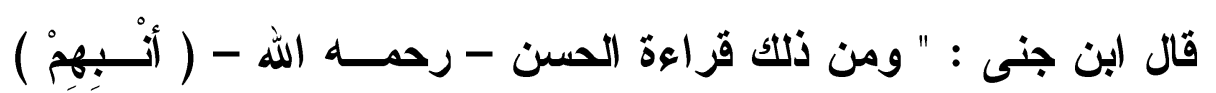

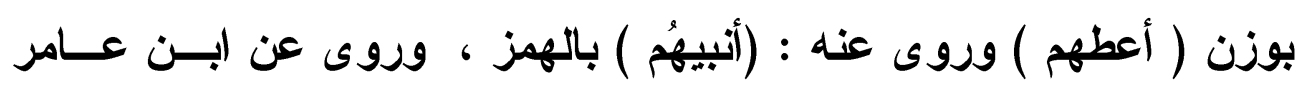

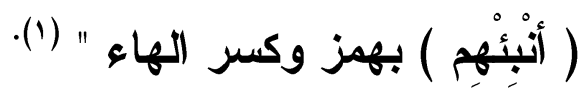

\section{قال (بن مجاهد : " وهذا لا يجوز " (؟).}

قال ابن جنى : " فقد علمت بذلك أن قول (بن مجاهد : هذا لا يجوز ، لا وجه له ، لما شرحنا من حاله " (ז).

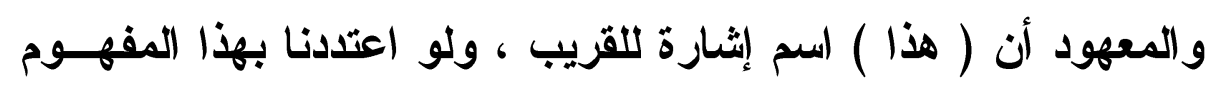

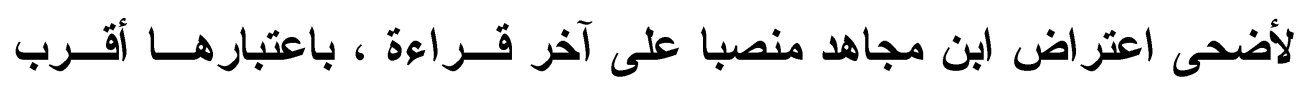

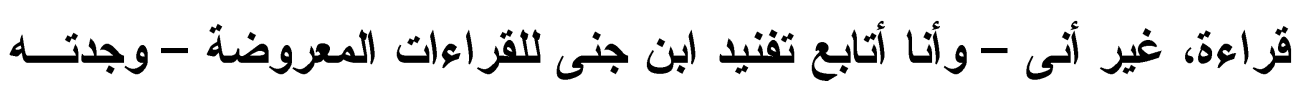

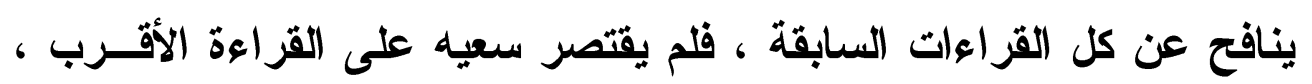

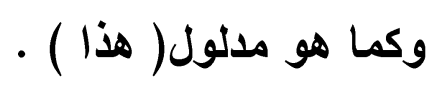

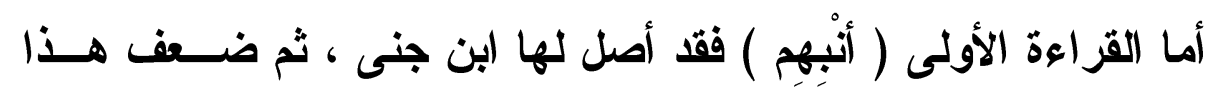

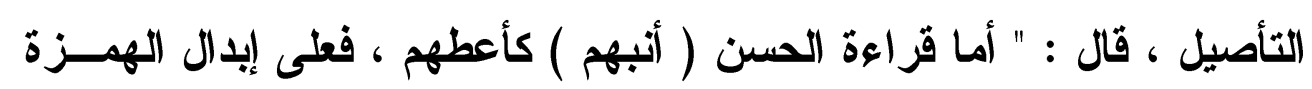

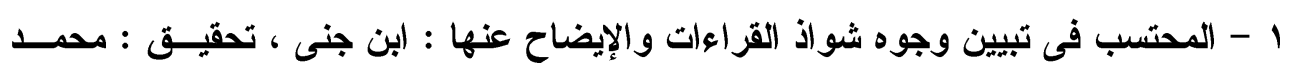

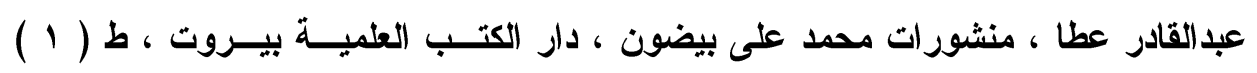

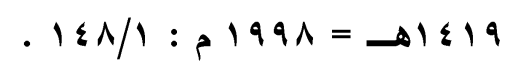

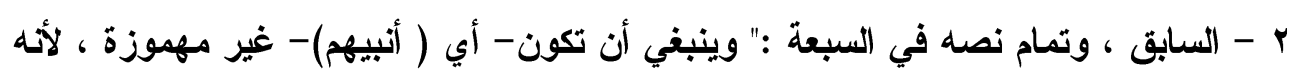

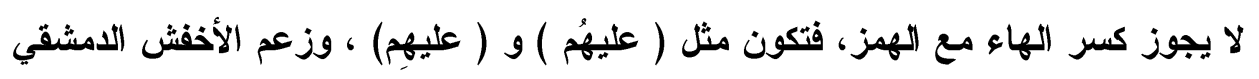

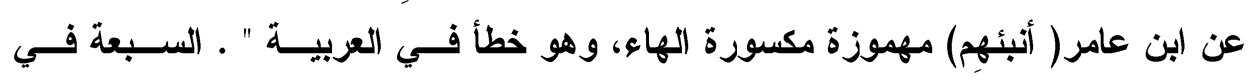

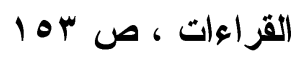

$$
\begin{aligned}
& \text { r - المحتسب : 105/1 . }
\end{aligned}
$$


الترقير الدول\$ ISSN 2356-9050
(1) 11
حولية كلية اللفة العربية بجرجا

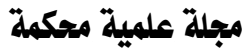

ياء ، على أنه يقول : أنبيتُ كأعظطَيتُ ، وهذا ضعيف فى اللغة ، لانه بدل لا تخفيف ، والبدل عندنا لا يجوز إلا فى ضرورة الثعر " (1). أما إبدال الهمزة ياء فقد أخذ به الكثير ، وهو معتمــد عنــــ علمـــاء الإبدال، وقد اختصه ابن السكيت - فى كتابه ( الإبدال ) - بفقرة خاصــة ، مليئة بالعديد من الأمثلة (؟).

كما أخذ به الاكتور رمضان عبدالتواب فى كتابه : ( مشــكلة الهـــزة

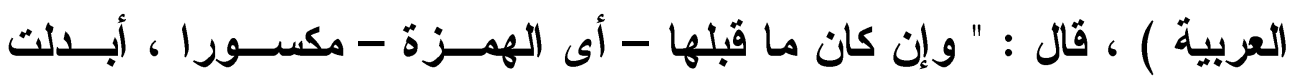

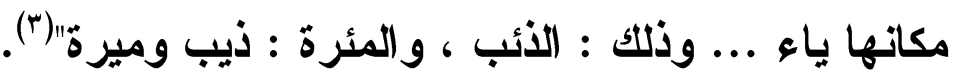

وكأن الأمر عند ابن جنى مرجعه إبدال الهمزة ياء ، فصارت ( أنبيهُهْ)

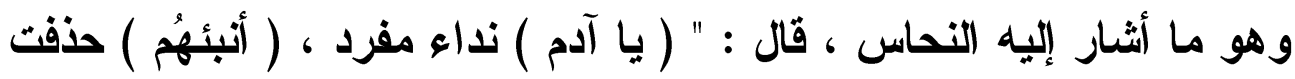

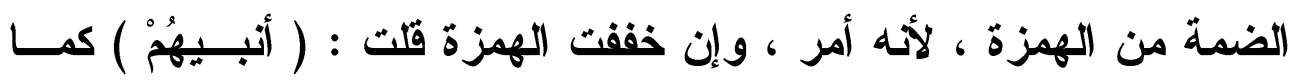

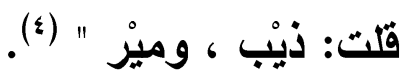

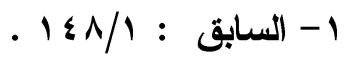

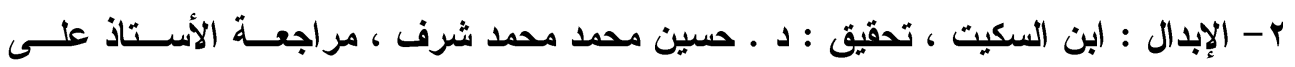

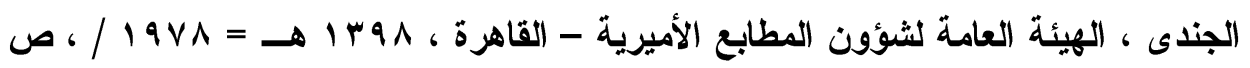
. IrV-1 ITt

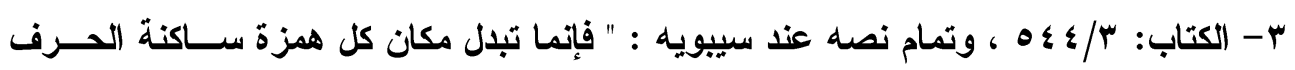

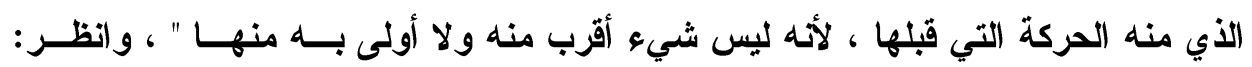

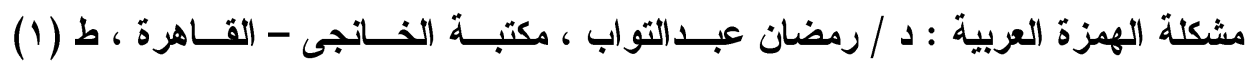

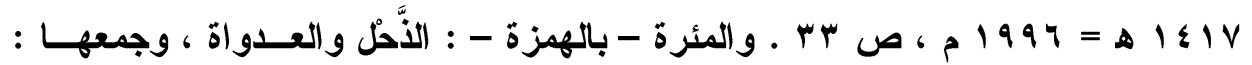

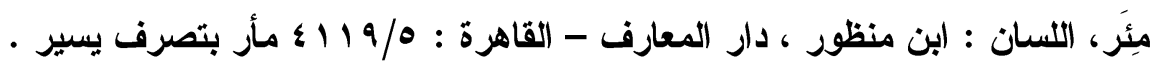

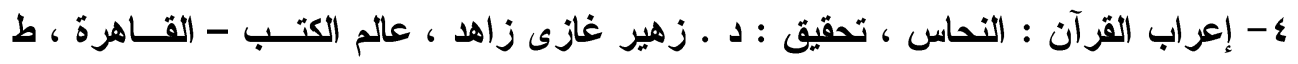

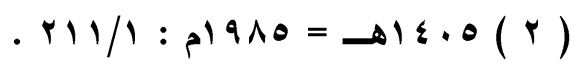

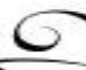


وعليه فعبارة ابن مجاهد السابقة : " وهذا لا يجوز " ، لعله قصد بهـــا من قرأ ( أنبيهزم ) بكسر الهاء ، فلم تحظ هذه الرواية بالقبول ، قال عنهــا الأزهرى : " وقد روى عن ابن عامر أنه قرأ (أنبيهم ) بحذف الهمزة ، كان جائز افى العربية ، ولا يجوز فى القراعة ، لأهه لم يقرأ به احد " ('). وقا علل ابن خالويه لبعد هذه القزاعة عن وجه الصواب ، قــائلا : " وهذا - أى القراعة بكسر الهاء - غلط ، لأن الهاء إنما تكسر إذا تقــدمتها كسرة أو ياء ، وقرأ الباقون ( أنْبئهُمْ ) وهو الصواب"(؟). بل ما أكده ابن خالويه في كتابه ( الحجة ) ، إذ يقول : " قوله تعالى: ( أنبئهمج ) قرأه ابن عامر بطرح الهمزة ، وإثبات الياء ، وكسر الهاء ، فإن كان جعله من أنبَْى ينبِى ، غير مهموز ، فهو لحن ، وإن كان خفف الهمزة، وجطها ياء ، وهو يريدها كان وجها " (r). كما فرق أصحاب المعاجم بين الفعلين ، قال ابن منظور : " ونبأ عليهم

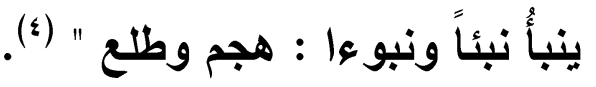

1- معانى القراعات : الأزهرى ، تحقيق : أحمد فريد المزيدى ، منشورات محمد على بيضون،

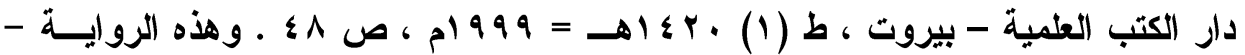

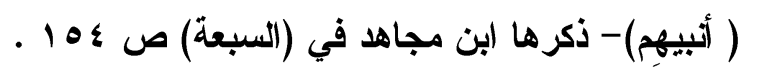

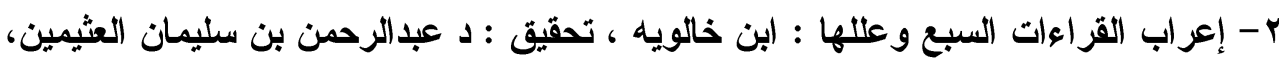

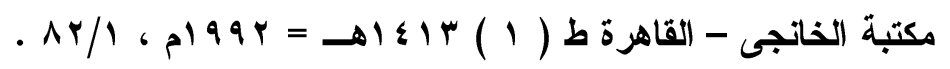

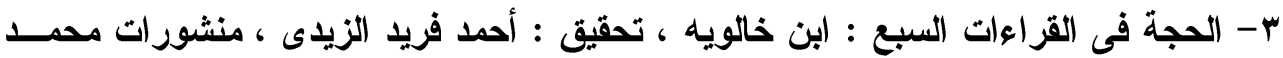

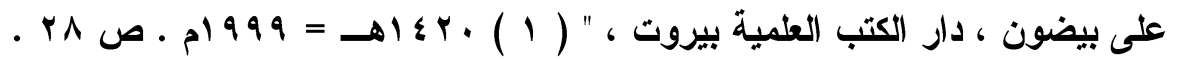

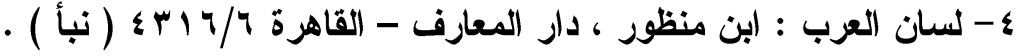




\section{الترقير الدولخ}

ISSN 2356-9050
(1) 1147
حولية كلية اللفة العربية بجرجا مجية

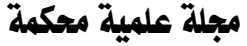

وقال فى مادة (نبا) : " نبا الشيع عنى ينبو، أى تجافى وتباعد " (1).

فالخلاصة - إذن - أن ابن جني وافق (بن مجاهد فى قراعة ( أنبيهِمْ ) وإن عد ابن جنى هذا من قبيل الإبدال ، فهو ضعيف فى اللغة ، ولم نجد لله صدى عن المتقدمين ، كابن السكيث ولا عند المتأخرين كالدكتور / رمضان عبدالتواب • وإن كان ابن خالويه قد جوز ما رآه ابن جنى ضعيفا فى اللغــة - أعنى : تخفيف الههزة وجعلها ياء - وما لم يجوزه ابن مجاهد من قراعة ابن عامر (أنبئهم) بهمز وكسر الهاء ، لـ يجوزه أيضـــا الأزهــرى وابــن

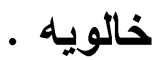

\section{r- قَالَتَعَالَّن:}

" ومن ذلك ما رواه ابن مجاهد عن روح بن أبى السََّّال : أنـــهـهـ قـرأ

( أوكملما عاهدوا) ساكنة الو واو"(r).

قال أبو الفتح : " لا يجوز أن يكون سكون الواو فى ( أو ) هذه علــى أنها فى الأصل حرف عطف ، كقزاعة الكافة ( أوكلمـــ ) مـن قبـلـ أن واو

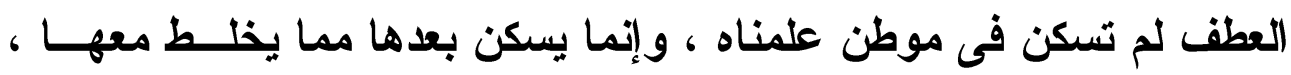

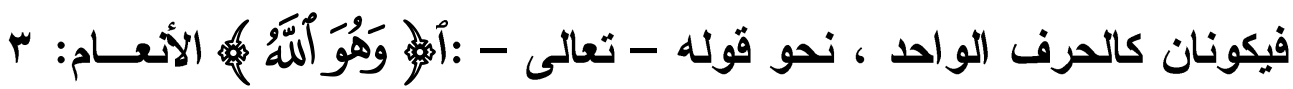

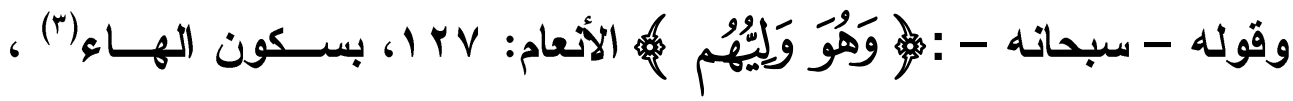
فأما واو العطف فلا تسكن من موضعين :

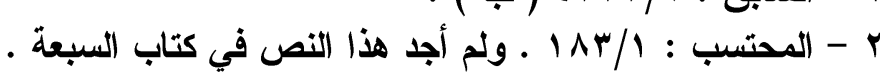

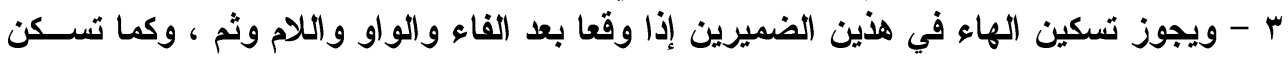

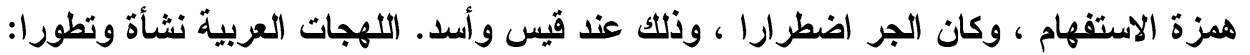

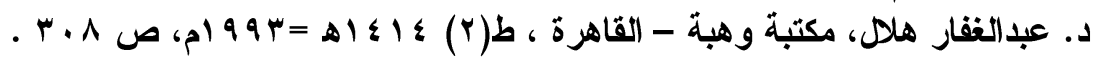


والآخـر : أنها هنا وإن اعتمدت على همزة الاســتههام قبلهـــا فإنهــا مفتوحة ، والمفتوح لا يسكن استخفافا ، و إنما ذلك فى المضموم والمكسور، نحو : كرْم زيد ، وعلْم الله ، وقد مضى ذكر ذلتك"(1).

وهنا وقع الاعتر اض من ابن جنى على ابن مجاهد ، أنه قرأ ( أوْ كلما عاهدوا ) ساكنة الواو، وقد جاء الاعتر اض من ابن جنى منمثلا فى أن واو العطف لا تسكن فى موضعين : أحســهما : إذا جـاعت فـى أول الكلمــة ، فالساكن لا يتئأ به ، وهذا أصل أثثاعه ابن جنى فى أكثر مـن مناسـبة ،

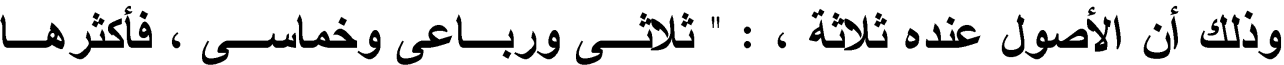

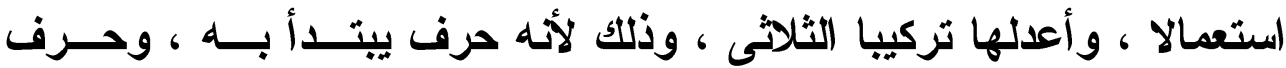
يحشى بهاه ، وحرف يوقف عليه " (r).

ثم قال بعد قليل : " والابتداء بالساكن ليس فى هذه اللغة العربية " (r). والآخر: أنها هنا ، وإن اعتمدت على همزة الاستفهام ، فإنها مفتوحة، والمفتوح لا يسكن استخفافا، وإنما ذلك فى المضموم والمكسور " (؛). وذلك لأن الضمة والكسرة من أصوات اللين الضيقة (•). أما القتحـــة

فهى صوت اللين المتسع(").

$$
\begin{aligned}
& 1 \text { - المحتسب : } 1 \wedge r / 1 \text {. } \\
& \text { r - الخصائص : 1.0/1. . }
\end{aligned}
$$

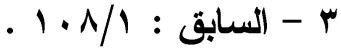

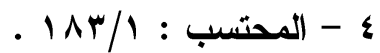

ه- فى اللهجات العربية : د : إبراهيم أنيس ، مكتبة الأنجلو المصرية ، r .. rم ، ص וN . .

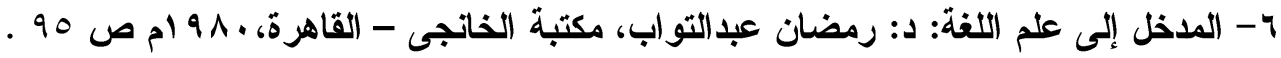


الترقير الدولخ ISSN 2356-9050

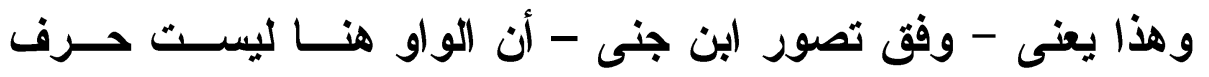

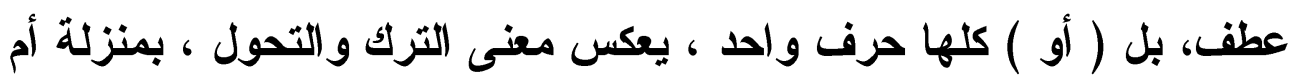

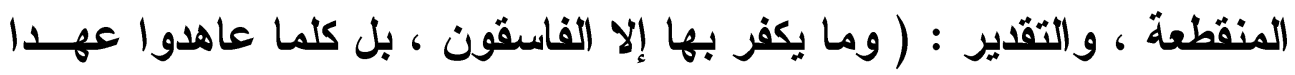
نبذه فريق منهم ) (')

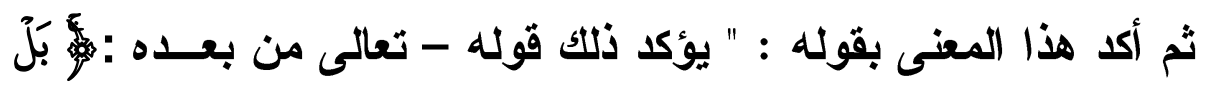

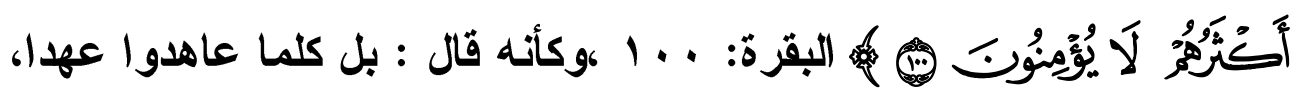

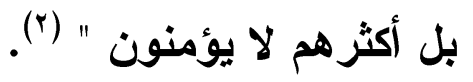
ومجيء ( أو ) بمنزلة ( أم ) المنقطعة أثثار إليه كثير من النحاة ، فقد

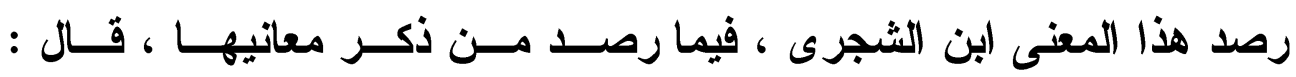

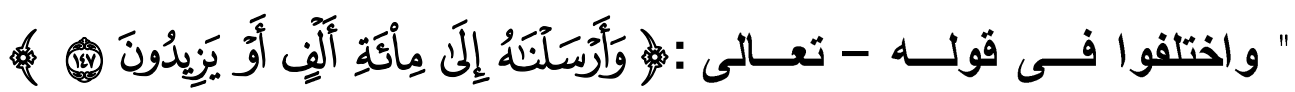
الصافات: V I I ، فقال بعض الكوفيين : أو : بمعنى الواو ، وقال آخــرون

منهم : المعنى : بل يزيدون ، وهذا القول ليس بشيع عند البصريين " ("). وعده - أى : الإضراب - ابن عقيل من استعمالات ( أو ) ، فقال : " للإضراب " ثم احتج ببيت جرير بن عطية :

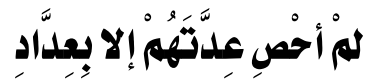

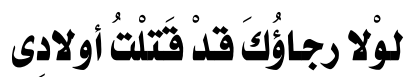

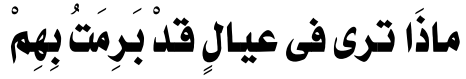
كانوا ثمانية أو زْادوا ثمانية

$$
\begin{aligned}
& 1 \text { - المحتسب : 1/ } 1 \text { | . } \\
& \text { r - السابق - }
\end{aligned}
$$

Y - أمالى ابن الثجرى : تحقيق ودراسة : د ـ ـ محمود محمد الطناحى ، مكتبـة الخـانجى -

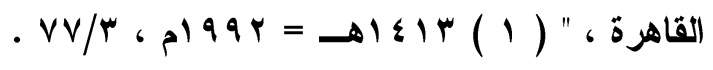




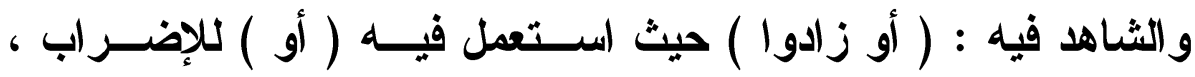

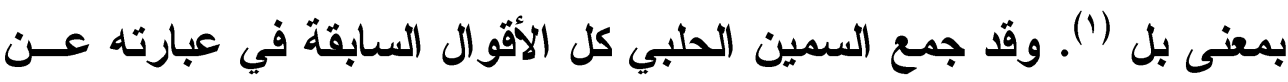

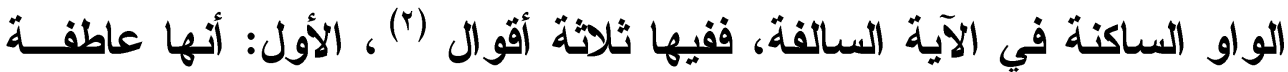
على الفاسقين ، وتقديرها ( إلا الأنين فسقوا أو نقضوا) ، ويقصد بــهـ أنـــه

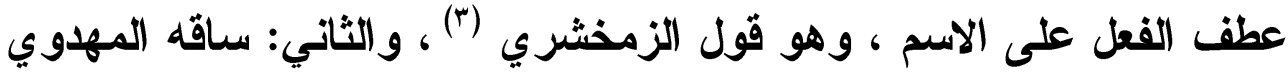

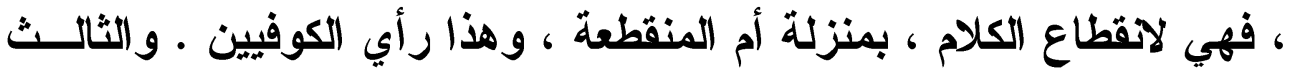

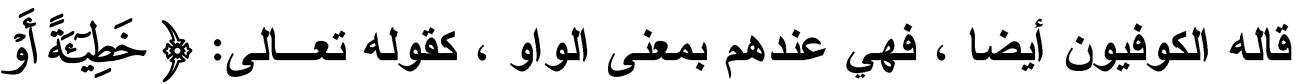

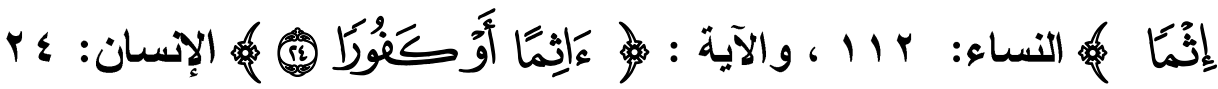
ثم شرع ابن جنى فى الانتصار لمذهبه ، قائلا : " وأو هذه التى بمعنى

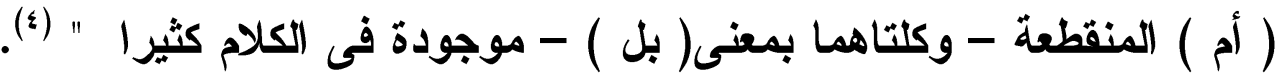

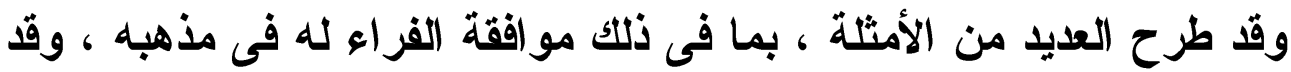
احتج الفراء بقول ذى الرمة ، وهو من الطويل:

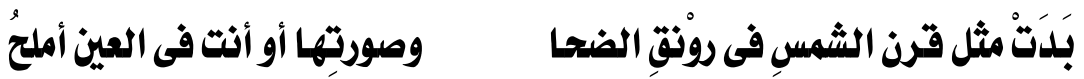

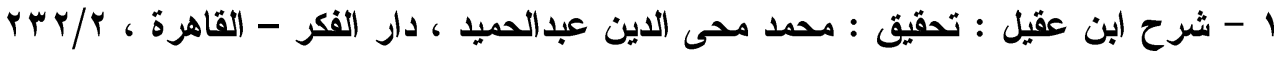

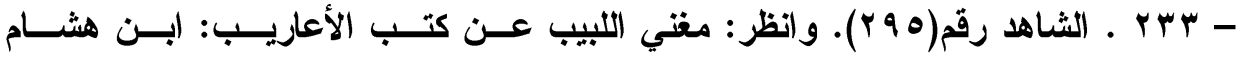

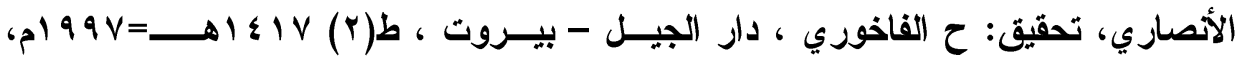

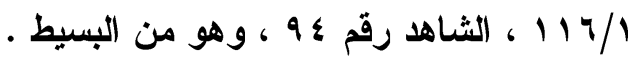

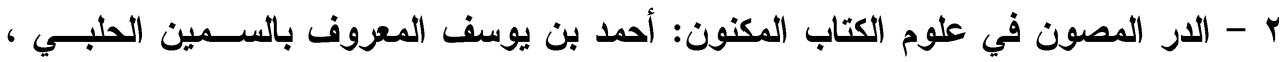

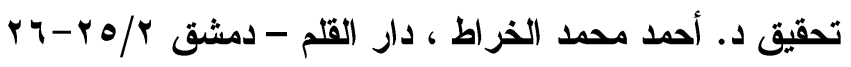

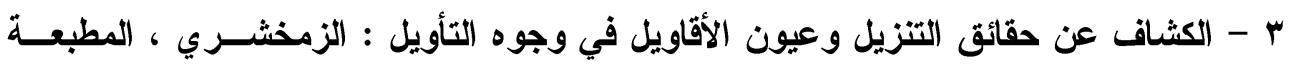

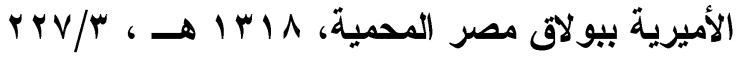

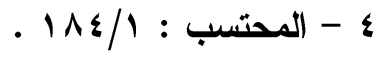

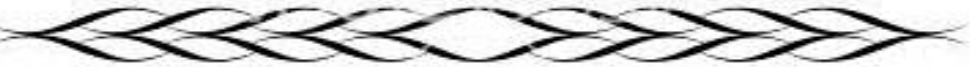




\section{الترقيم الدوله \\ ISSN 2356-9050}

قال : معناه : بل أنت فى العين أملح (').

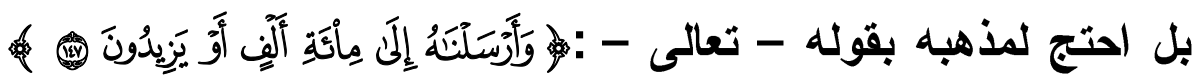

قال : معناه : بل يزيدون (r)

وكذلك ومما تجدر الإثارة إليه أن ابن جنى - وبعد ان منع الواو من

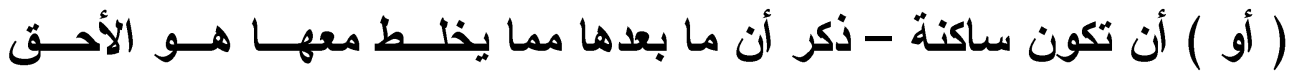
بالتسكين ، فيكونان كالحرف الواحد ، ضاربا المثل بقوله - تعالّى : ( وهُـــو الله ) وقوله - تعالى - : (وهْو وليهم ) بسكون الهاء وتوجيه ذلك أن الهاء لما توسطت مضمومة بين واوين ثقل ذلك ، والعرب تجيز التحريك و التسكين فى أصوات الحلق ، فضلا عن أن الهاء لما اتصلت بمـــا قبلهـــا مــن واو ، وكاتت لا تنفصل عنها صارت كالكلمة الواحدة ، فخفقت الكلمــة ، وأســكن

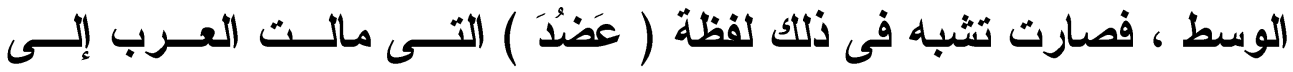
تخفيفها، فقالت ( عَضْذ ) وهى لغة مشـــهورة مســتعملة ، نــص صــاحب ( المغني في توجيه القراعات العثر المتواترة ) على أنها لغة نجد. (ץ)،

$$
\begin{aligned}
& 1 \text { - الخصائص : / 19/r . }
\end{aligned}
$$

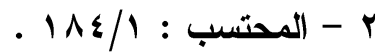

r - انظر : اللهجات العربية فى التراث : د ـ ـ أحمد علم الجندى ، الارار العربية للكتاب ، تونس

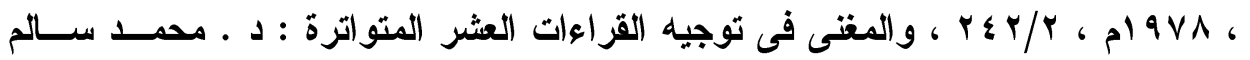

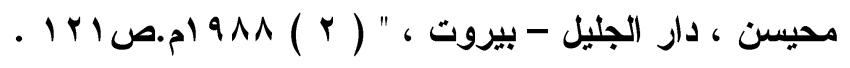




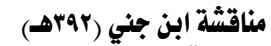

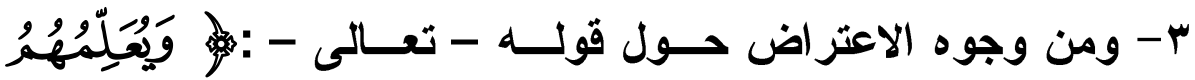

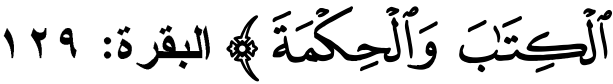

قال ابن مجاهد : قال ابن عباس : سألت أبا عــرو عـن ( يعلمهــ

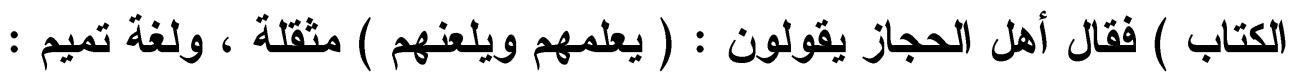

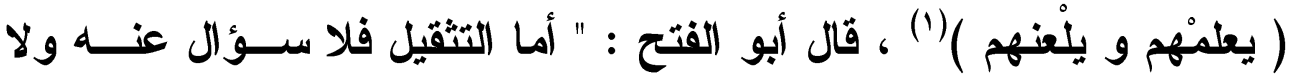

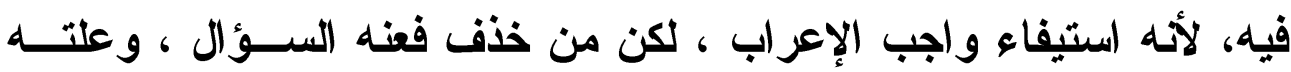

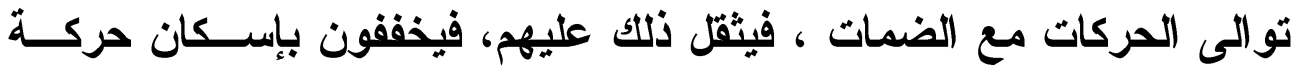

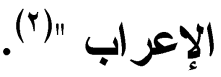

وهنا وقع الخلاف حول وله - تعالى - : ( يعلمهم الكتاب ) فذهب (بن

مجاهد إلى أن أهل الحجاز يقولون : ( يعلمهم ) مثقلة ، ولغة تميم (يطلمهر)

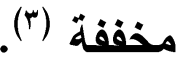

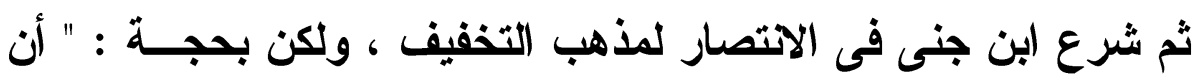
التثقيل فلا سؤال عنه ولا فيه ، لأنه استيفاء واجب الإعراب ، ولكـن مسن

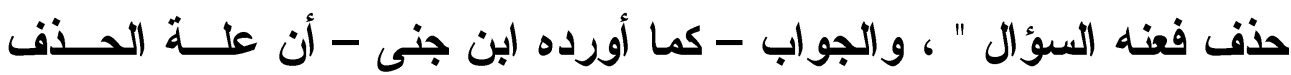

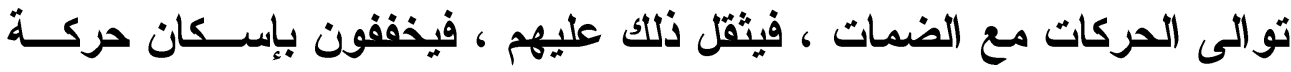

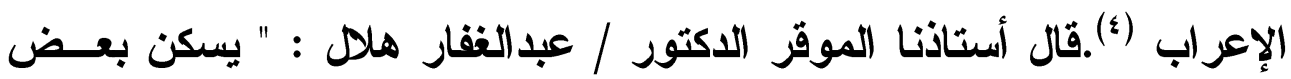
العرب كبنى تميم وغيرهم المتحرك فى بعض الأوزان المستعملة فى الأسماء

$$
\text { ؟ - المحتسب : المحتب : 190/1 } 190
$$

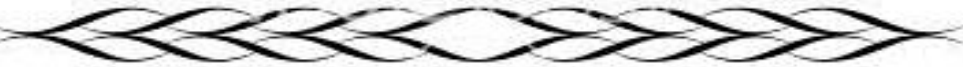




\section{الترقير الدولخ \\ ISSN 2356-9050}

والأفعال رغبة فى التخفيف " (1). بل هذا ما سبق إليه الاكتور إبراهيم أنيس

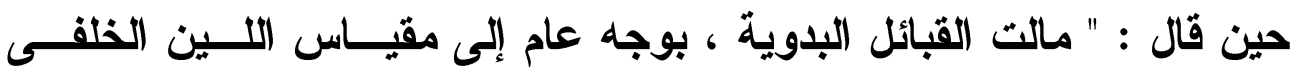

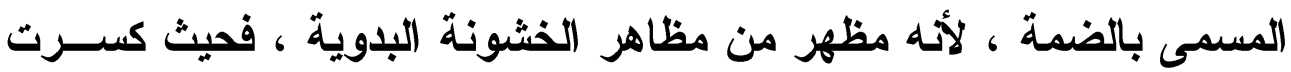

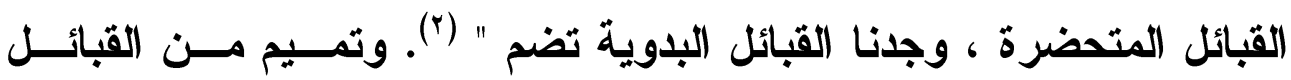

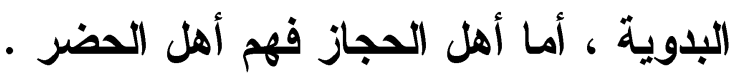

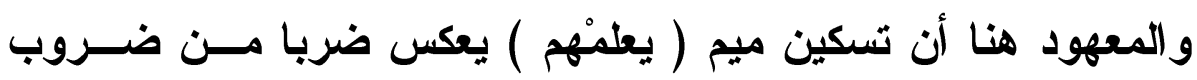

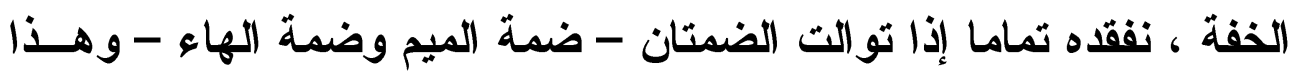
الضرب لم يختلف عليه المتقلمون ولا المتأخرون .

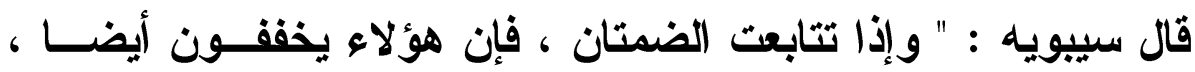

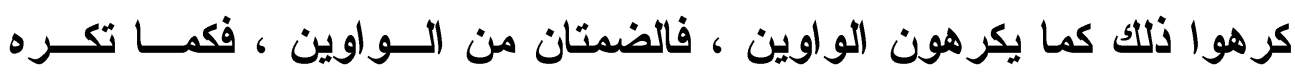
الو اوان كذلك تكره الضمتان لأن الضمة من الواو "("). و هكذا تتضح الروئة المنوطة بهذه الآية ، وأن الإسكان مقصد جوهرى

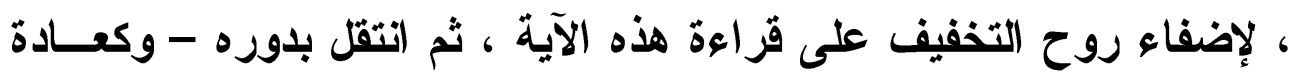

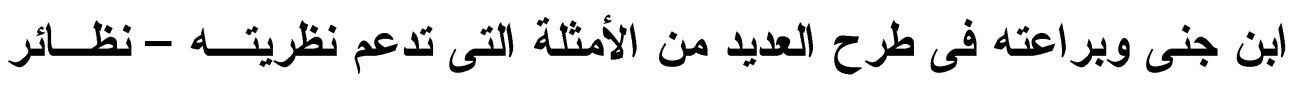
قر آنية أصلها التخفيف - ومن ذلتك قراعة أبى عمرو ( فتوبوا إلى بـارئكم )

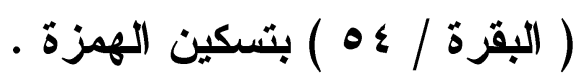

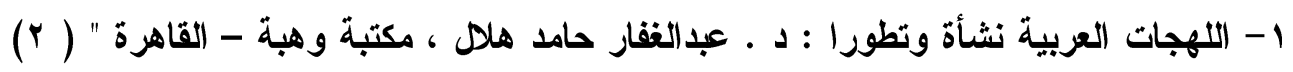

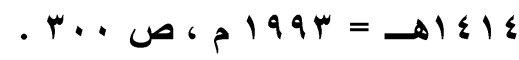

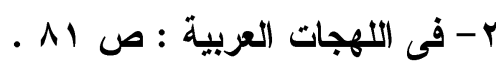

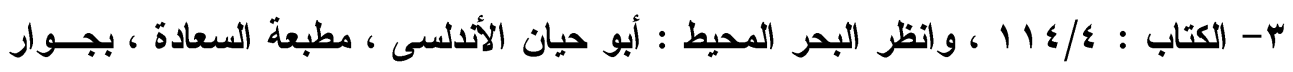

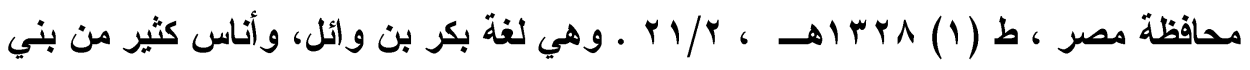

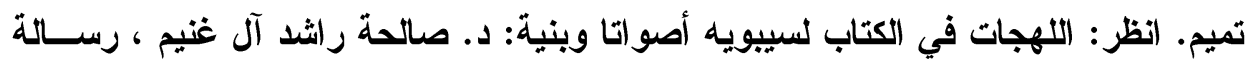

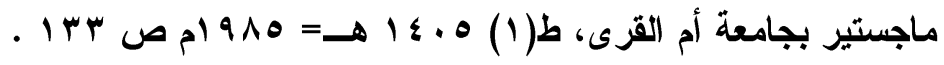

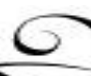




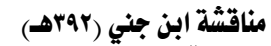

قال فى البيان : " روى عن أبى عمر اختلاس الكسرة فى الهمزة مـن

( بارئكم ) لكثرة الحركات طلبا للتخفيف " (1).

هذا ، وقد أدرج الاكتور / عبدالغفار هلل هذه الظاهرة ضمن ظــواهر

التخفيف التى استعان بها ، وهو يتحدث عن التخفيف بالإسكان (r).

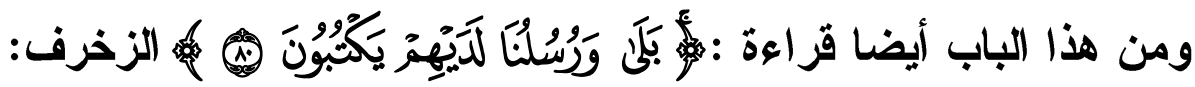

ـ بسكون التلام (ז).

ومن هذا الباب أيضا قول جريز ، وهو من البسيط :

ونهر تيرى فلا تعرفْكم العربُ

سيروا بنى العمِّمَالأهوازُمنزلكم

بإسكان الفاء من ( تعرفْكم ) (ء) )

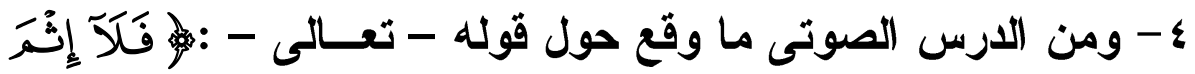

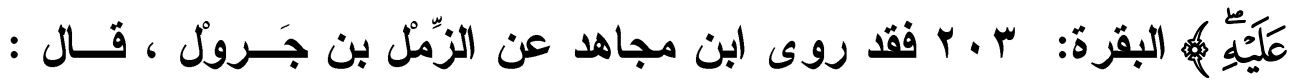
سألت سالم بن عبدالله بن عمر عن النَّْر ، فقرأ (ومن تعجل فى يومين فَلَم

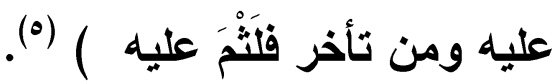

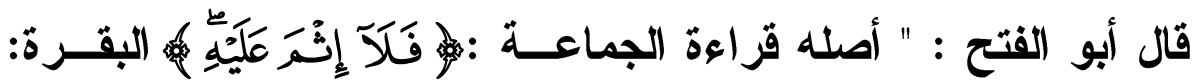

1 - البيان فى غريب إعراب القرآن : ابن الأنبارى ص V^ ، الآية ( عـ ) من سورة البقرة . r - أنظر اللهجات العربية : ص r •r . .

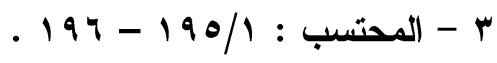

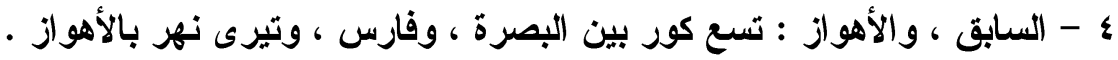

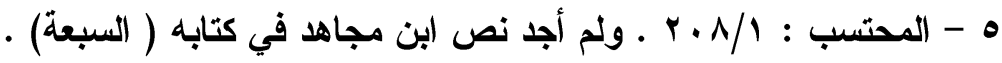




\section{الترقير الدولخ \\ ISSN 2356-9050}

إلا أنه حذف الهمزة (') البتة ، فالتقت ألف (لا) وثثاء ( الإثم ) ساكنين،

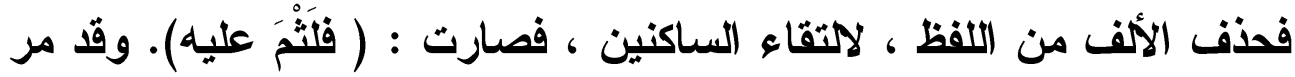

بنا من حذف الهمزة اعتباطا وتعجرفا (ץ)، من نحو هذا أثياء كثيرة " (r).

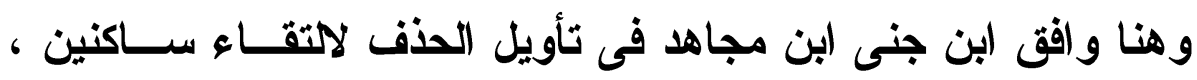

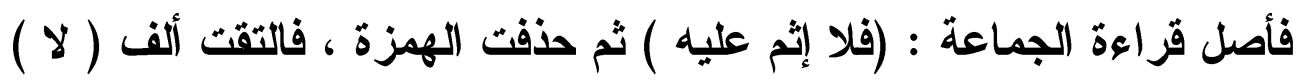

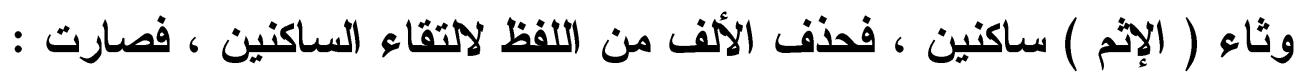

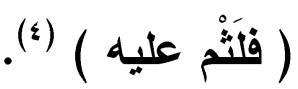
وقد أيد ابن جنى مذهبه الموافق هذه المرة مذهب ابن مجاهد بالعديـــ

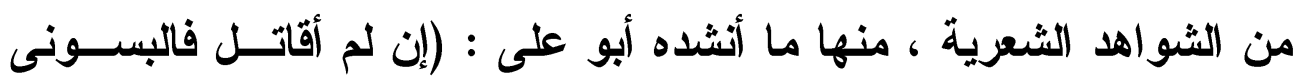
برقعا )

\section{أراد : فألبسونى ، ثم حذف الهمزة (•).} ومنها ما أنثده أبو الحسن ، وهو من الطويل : وتَسْمَعُ منز تَحْتَ العجاج لهزْمَلَا

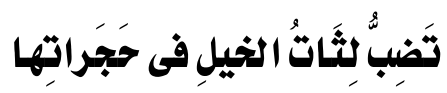

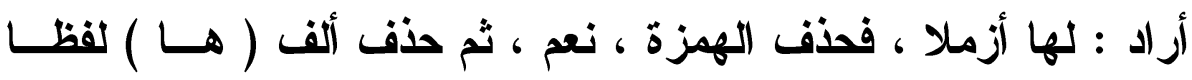

لسكونها وسكون الزاى بعدها (ج).

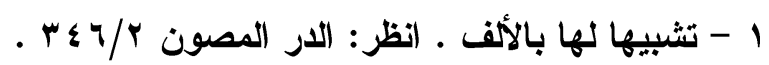

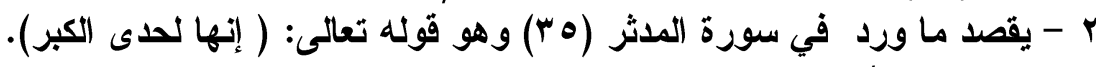
r - السابق :

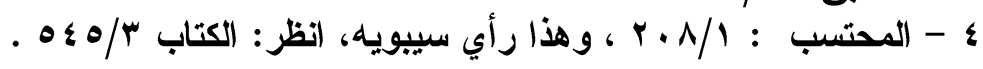

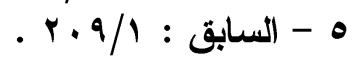

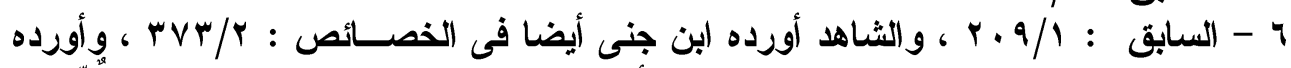

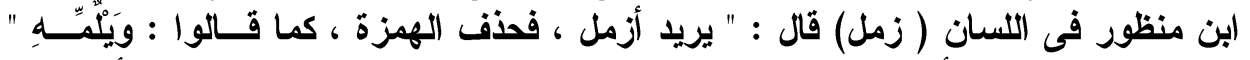

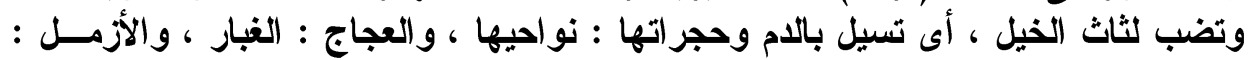
الصوت ، وجمعه الأز امل . 
مناقشة ابن جني (بrara)

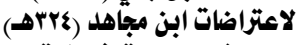

على بعض الروايات في الماتهتب مئب

ومن ذللك قراعة ابن كثير : ( إنها لحْى الكبر ) المدثر / هب ، ومـــا

فيه إلا حذف الهمزة لا غير (').

قال أبو حيان : " وهو حــنف - أى حـــف الههــزة - لا ينة هــاس ، وتخفيف مثل هذه الهمزة أن تجعل بين بين ، والظاهر أن هذه الجملة جواب

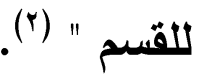

كما عد (بن جنى - من هذا القبيل - لفظ الجلالة ( الله ) وتحقيق ذلك أن يكون أصله ( الإله ) فحذفت الهمزة التى هى فاء (). وقد أثنار إلى مثثله الر اغب فى المفردات ، والجوهرى فى الصحاح ، وابن منظور فى اللسان ، فإلاه أصل لقظ الجلالة الله على فعال بمعنى مفعــول ، لأكسـه مـــألوه ، أى : معبود ، فلما دخلت عليه الألف واللام حذفت الهمزة تخفيفا ، لكثرتــهـهـ فـى (الكعلام (\&)

يرجح ذللك ما رواه المنذرى عن أبى الهيثم وقد سأله عن الثتقاق اسم الله - تعالى فى اللغة ، فقال: " كان حقه إلاه ، وأدخلت الألف والله تعريفا ، فقيل الإلاه ثم حذقت الهمزة استثقالا لها ، فلما تركوا الههزة حولوا كسرتها فى اللام ، التى هى لام التعريف ، وذهبت الهمــزة أصـــلا ، فة فــالا (ألاِــاه) فحركوا لام التعريف ، التحى لا تكون إلا ساكنة ، ثم التقى لامان متحركــان ، فأدغموا الأولى فى الثانية فقالوا : الله"(ه).

$$
\begin{aligned}
& \text { 1 - المحتسب : } \\
& \text { r - البحر المحيط : rVA/A }
\end{aligned}
$$

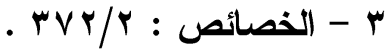

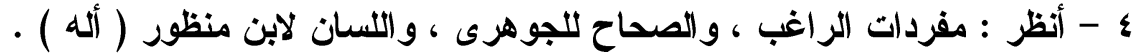

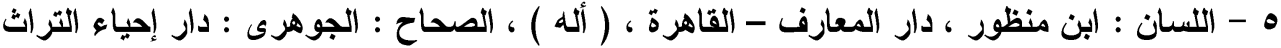

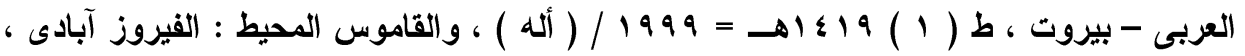

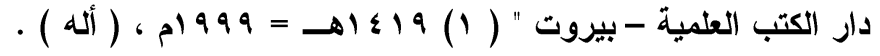




\section{الترقير الدولخ}

ISSN 2356-9050
(1) $11 \%$
حولية كلية اللفة العربية بجرجا مجلة علمية محكمة المية

فهنا وافق ابن جنى ابن مجاهد فى تصوره ، الأمر الأى يعكس انتفاء

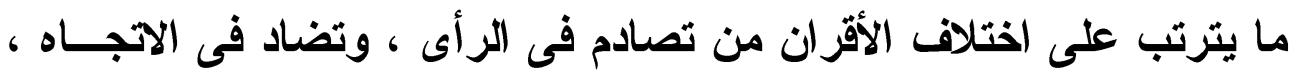
و هكذا ينبفى أن يكون الحكماء .

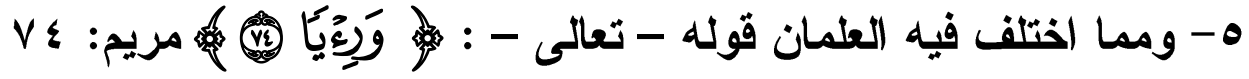

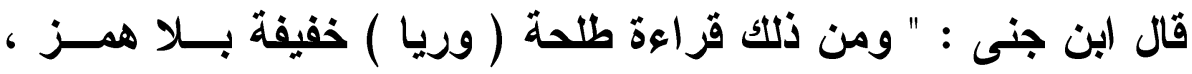

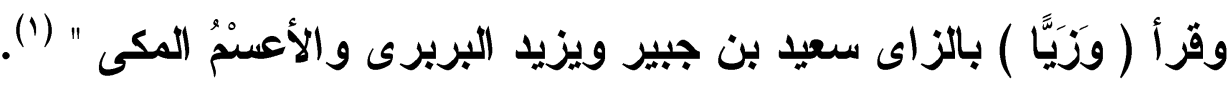

قال ابن جنى: " النظر من ذلك فى ( وريا ) خفيفة بلا همز،وذلك أنــهـ

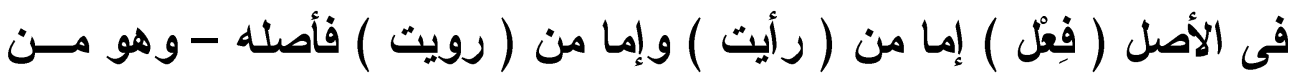

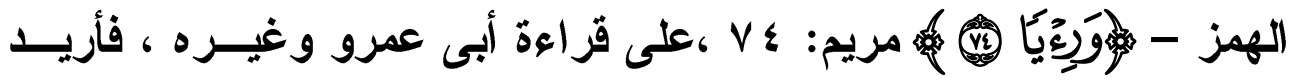

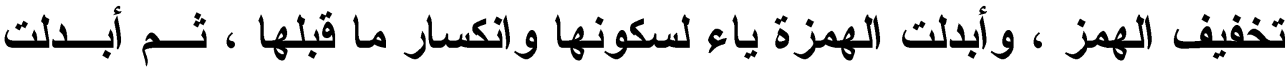

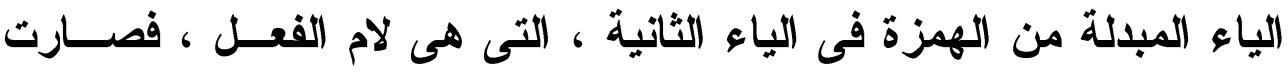

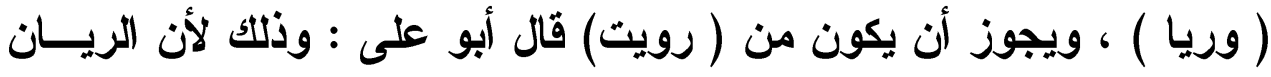

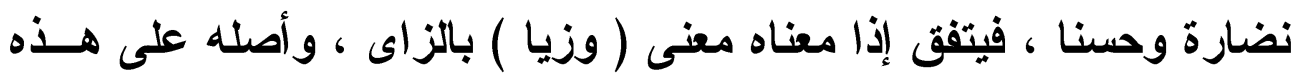

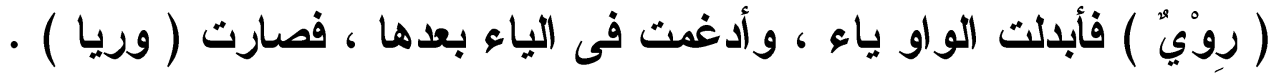

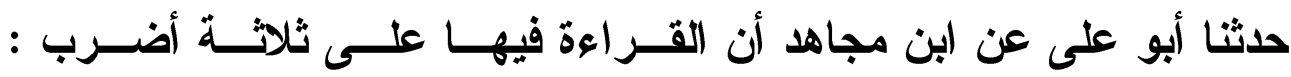

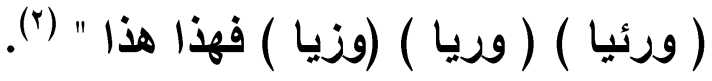
إذن فقد تمخض عن هذه الآية عدة قراعات :

- قر اعة طلحة : (وريا) خفيفة بلا هزز، ولم أجدها في كتاب ( السبعة) .

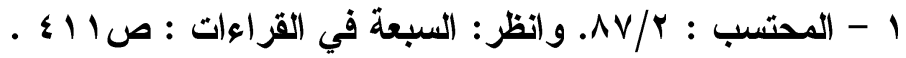

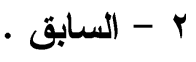




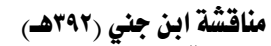

r - قراعة سعيد بن جبير ويزيد البربرى والأعسم المكى : ( وزيا ) بالزاى،

$$
\text { ولم أجدها في كتاب ( (لسبعة) . }
$$

ب- قر اعة أهل الكوفة وأبى عمرو : ( ورئيا ) بالههز ، وهي قـراعة ابــن

كثير وأبي عمرو وعاصم وحمزة والكسائي (').

ع - قر اعة أهل الكوفة ( وريا ) مشددة بلا همز ، وهي قراعة ابـن عـامر

ونافع (r)

هذه القراءات الأربع أثشار إليها ابن جنى فى ( المحتسب ) (ז) ، كمــا

رصدها أبو جعفر جملة واحدة فى ( إعراب القرآن ) (؛). وأضاف أبو حيان :

ه- ( ورياء ) بالياء ، بعدها ألف ، بعدها همزة ، حكاها اليزيلى (•).

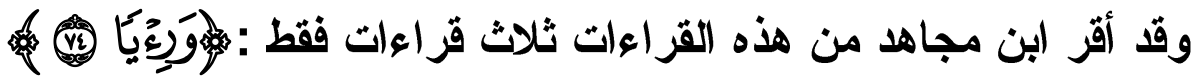
( وريا ) ( وزيا ) (")، وضرب صفحا عن البعض الآخر ، على الرغم مسن

$$
\begin{aligned}
& 1 \text { - السبعة : ص|إ }
\end{aligned}
$$

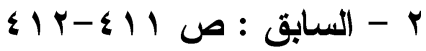

$$
\begin{aligned}
& \text { r - المحتسب : Nv/r . }
\end{aligned}
$$

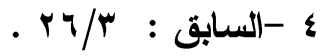

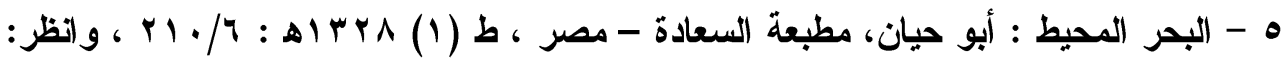

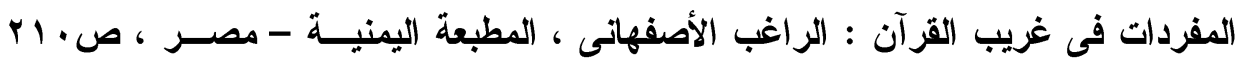
كجة القراءات : ابن زنجلة ، تحقيق : سعيد الأفغانى ، مؤسسة الرسالة - بيروت ط (ه)

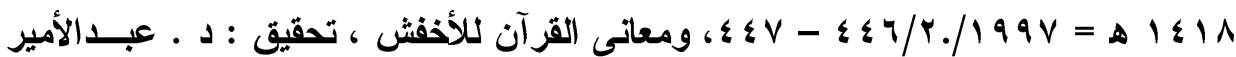

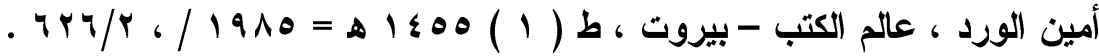

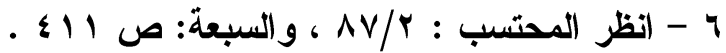




\section{الترقير الدولخ \\ ISSN 2356-9050}

إثشارة المفسرين وعلماء القراءات وعلماء معانى القرآن و المعجميين إلـى

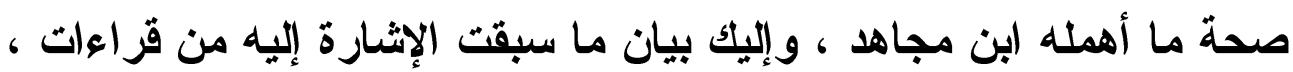
وفق تأويل ابن جنى ، ومدى مو (فقته غيره له . 1- أما قر اءة طلحة ( وريا ) بياء مخفقة ، غير مهموزة ، فتحتمـل

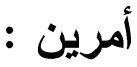

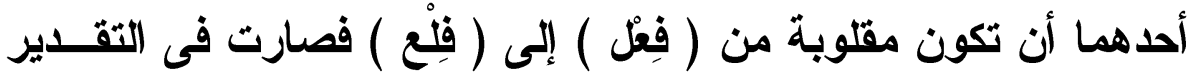

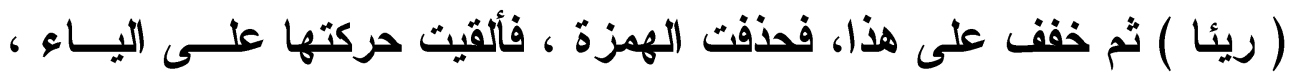

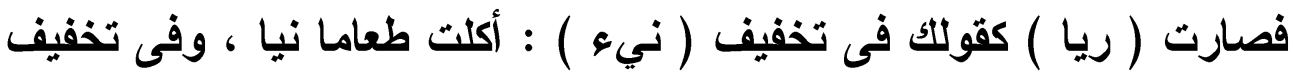
الجيئة : الجية فهذا أحد الوجهين فى ( ريا ) بالتخفيف (1).

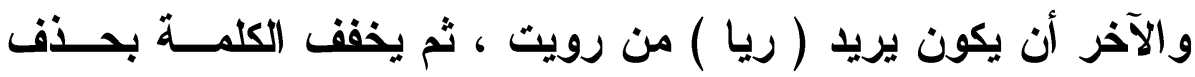

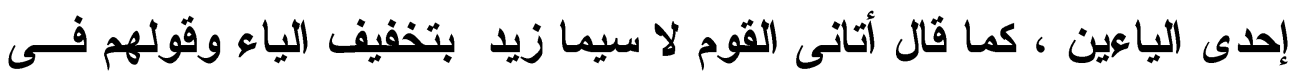

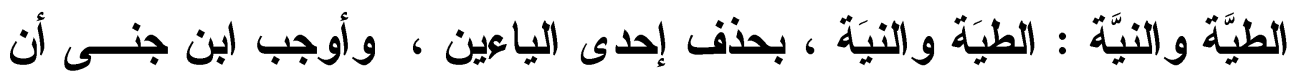

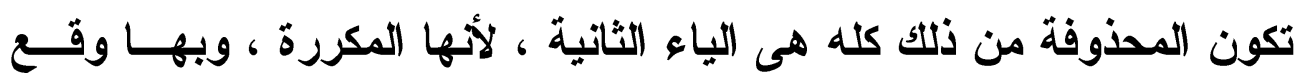
الاستثقال ، ولأنها لام ، وقد كثر حذف التلام حرف علة ، كمائة ورئة ونئة ،

وقلما تحذف العين (ץ).

و الحقيقة أن هذه القزاعة لم تحظ بقبول واسع كغيرها من القــــاعات ،

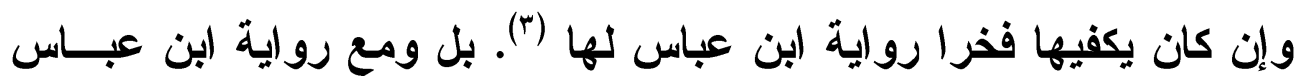

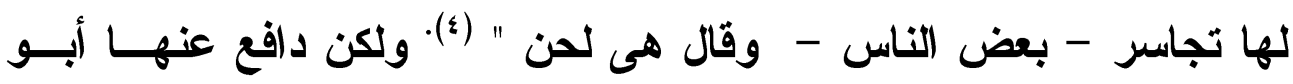

$$
\begin{aligned}
& 1 \text { - السابق : Av/r . }
\end{aligned}
$$

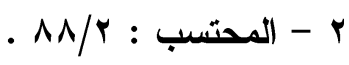

$$
\begin{aligned}
& \text { r - البحر المحيط : 11/ } \\
& \text { ع - السابق - الع }
\end{aligned}
$$




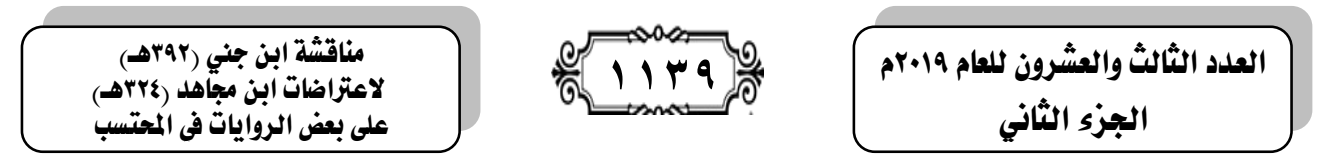

حيان ، فقال : " وليس كذلك - أى ليست بلحن - بل لها توجيه ، بأن تكون

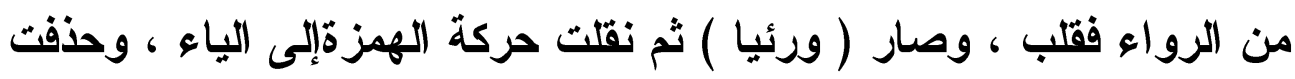

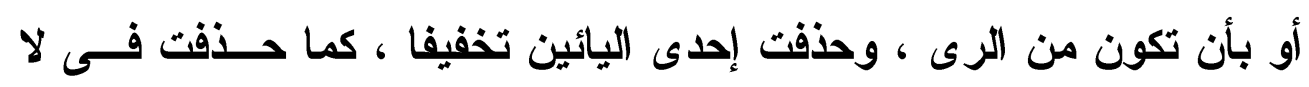

سيما " (1) بان لكون

بل نص أبو حيان على أن المحذوفة الياء الثانية ، " لأنها لام الكلمة ،

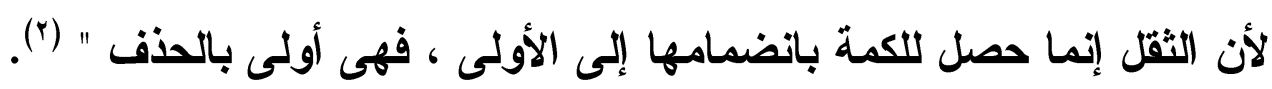

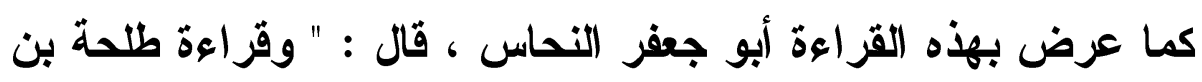

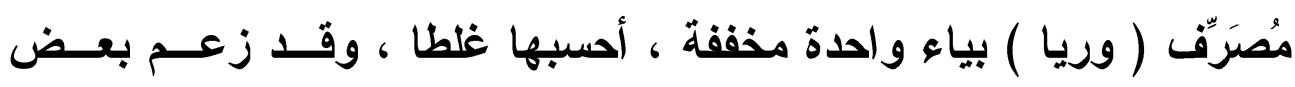
النحويين أنه كان أصلها ( ورئيا ) ثم حذفت الهمزة"("). وعليه فلا يقدح بثدة فى ابن مجاهد أنه أهمل هذه القراعة .

أما قراعة سعيد بن جبير ويزيد البربرى والأعسم المكـى : ( وزيَّــا )

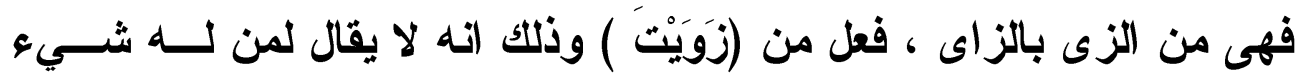

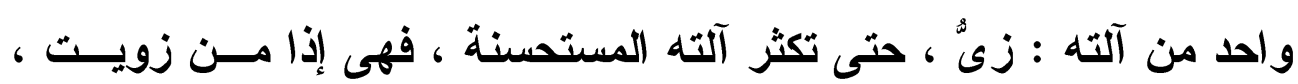

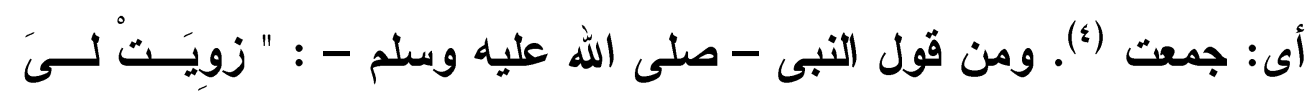

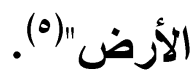

1 - وهو نفس المثال السابق الذى سبق أن استعان به ابن جنى لتوضيح رؤيته . r

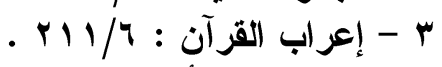

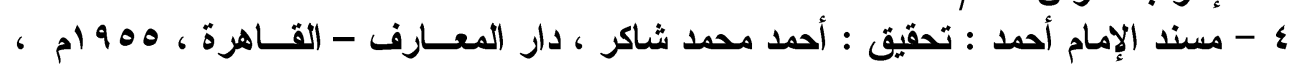

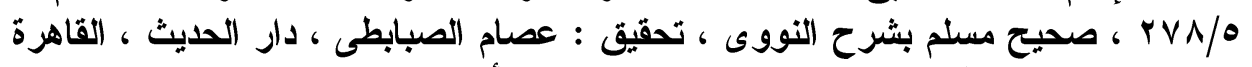

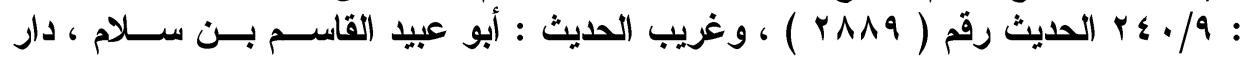

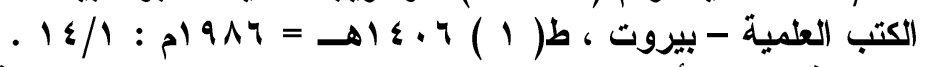

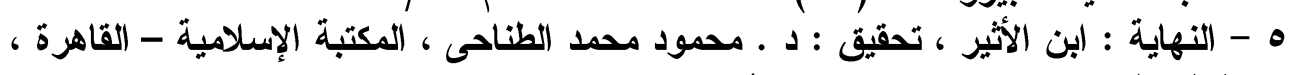
b

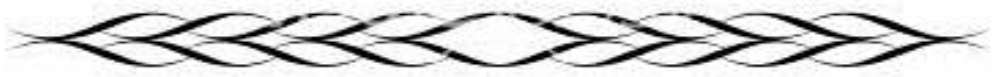




\section{الترقير الدوله \\ ISSN 2356-9050}

ومن قول الأعشى :

زَوَى بِين عَيْنَيْهِ على الملماجِمُ (1).

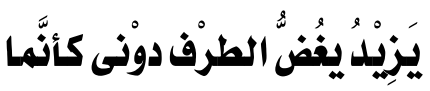

وأصله (زونيٌّ) فقلبث الواو على ما مضى ، وأدغمث فى الياء (r).

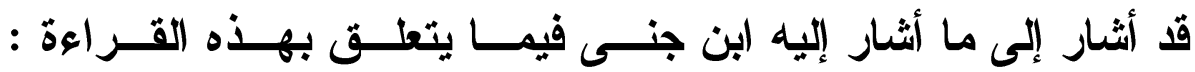

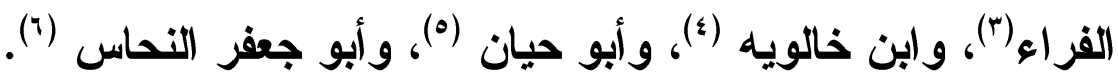

أما القر اعة الثالثة : ( ورئيا ) باللهمز ، والقر اعة الر ابعــة ( وريَّــا )

مشددة بلا همز ، فقد ارتبطتا بوجه من الوجوه ، فأصل القراعتين عند ابـن جنى من الهمز ، وهى قراعة ابحى عمرو ، فإذا أريد تخفيف الههز ، أبــلت

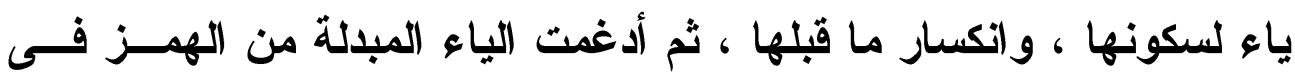
الياء الثانية ، التى هى لام الفعل ، فصارت ( وريًّاً ) : ويجوز أن يكون من رويت ، فأصله على هذا ( رونى ) فأبدلت الواو ياء ، وأدغمت فـى اليــاء

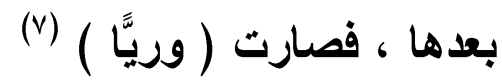

1 - الثاهد من بحر الطويل، وقد ورد بغزيب الحديث للهـروى : 10/1 ، وزوى المعساجم :

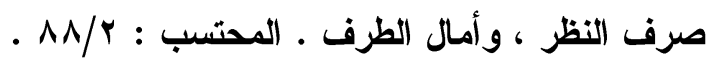

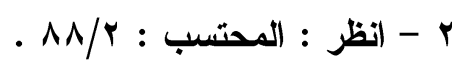

r - معانى القرآن : الفراء ، تحقيق : د ـ ـ ـ صلاح عبدالعزيز الســيد ، دار الســلام للطباعــة

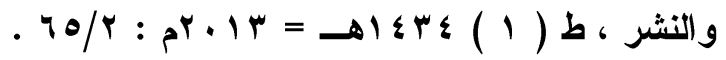

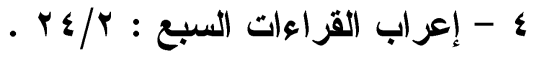

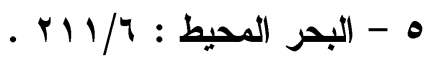

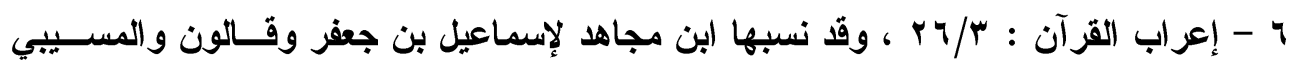

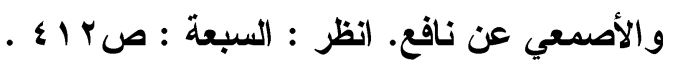

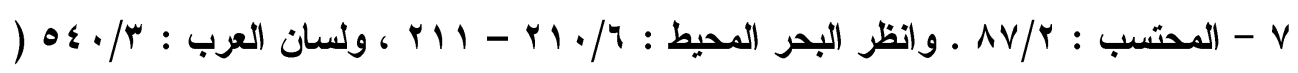
رأى ) 
وقد حسن النحاس هذه القراعة ، ووافق ابن جنى فى تأويله ، قـال : " قراعة أهل المدينة فى هذه حسنة ، وفيها تقديران : أحدهما أن يكون مسن

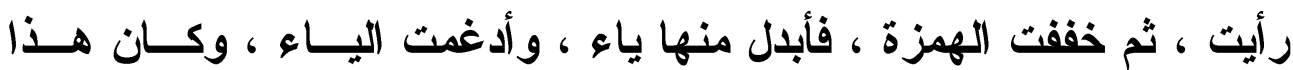
حسنا، لتتفق رؤوس الآيات ، لأنها غير مهموزات " (1). وعليه - فمن - همز فمعناه : المنظر الحسن ، ومن لم يهمـزز فلــه

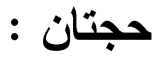

إحداهما : أن يكون قد أراد الههز فترك ، كما قرعوا ( خير البريسـة ) والأصل البريئة ـ والحجة الثانية: أن تأخذه من الرى ، وهو امتلاء الثباب و النضارة ، أى : ترى الرى فى وجوههم"(†). أمسا القزاعة الخاصة فقد وقت عليها عند أبى حيان ، فله يشر إليهــا ابن جنى ، ولا ابن مجاهد، ققد قرى ( ورياء ) بياء بعدها ألــف ، بعـــها هزة ، حكاها اليزيلى ، وأصله و ( رئاء ) من المرآة، أى : يرى بعضهم

بعضا حسنه " (r)

إذن فقد انتظمت القراعات سالفة الأكر ثلاثةة مستويات : المستوى الأول : وهو الأثـــهر والأوضــح والأفصــح بــين ســائر المستويات ، وق انتظم قراعات ثثلاث : ( ورئيا ) ( وريَّا ) ( وزيا ) وقـــ وافق فيه ابن جني (بن مجاهد فيما ذهب إليه ، قال ابن جنى : " حدثنا أبـو على عن ابن مجاهد أن القراعة فيها - أى فى الآية - على ثُلانـــة أضـــرب

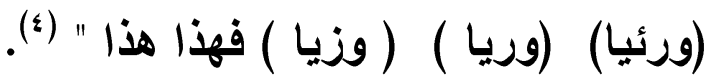

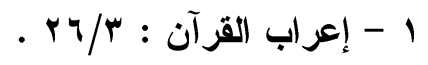

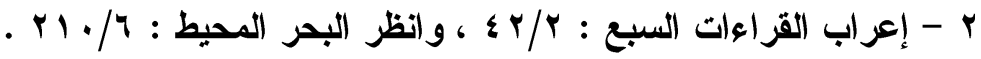

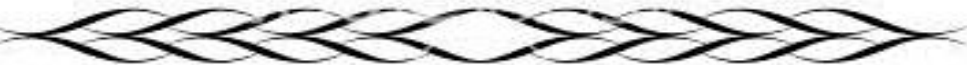




\section{الترقيم الدولخ}

ISSN 2356-9050

المستوى الثانى : وقد انتظم قراعة ( وريا ) مخففة الياء بلا همـز ،

ساقها ابن عباس عن طلحة، وقد تجاسر عليها البعض - كما سبق - وقال: هى لحن ، وقد رد عليهم أبو حيان ، وهى قراعة لم يشر إليها ابن مجاهـــ،

وقد ذكرها (بن جنى .

المستوى الثالث : وقد انتظم قراعة اليزيدى ( ورياء ) بياء بعدها ألف

بعدها همز ، ساقها أبو حيان، ولم ينص عليها (بن جنى ولا ابن مجاهد . وكأن ابن مجاهد قد ساق من قراعات هذه الآية ما انتظمه المســتوى الأول فقط ، وهى القراعات الأثهر والأدق ، الأمر الأى يعكس تفوق ابـن جنى على ابن مجاهد ، حتى فيما برع فيه ابن مجاهد من علم القراعات .

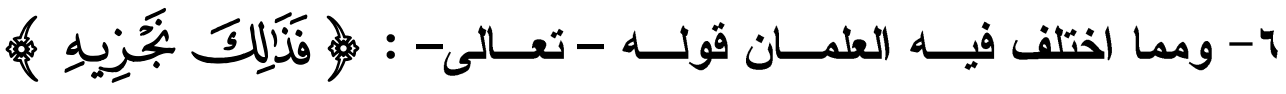

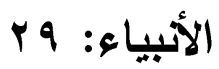

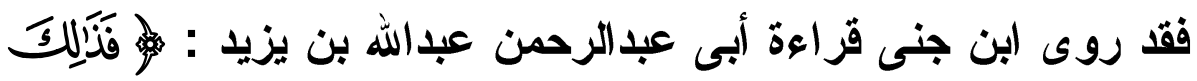

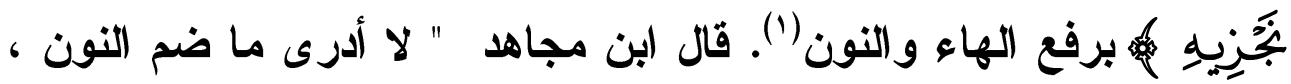

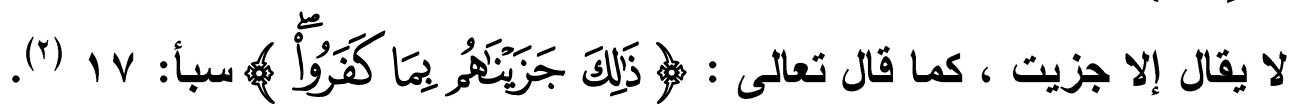
قال ابن جنى : " هو لعمرى غريب فى الاستعمال ، إلا أن له وجها أنا

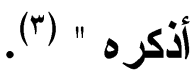


إذن فقد وافق ابن جنى ابن مجاهد فى استغرابه لهذا الوجه : " وذلك

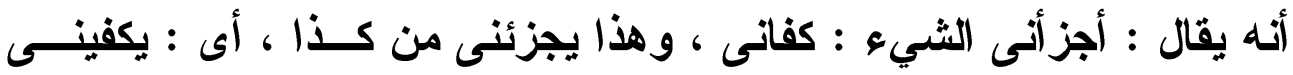

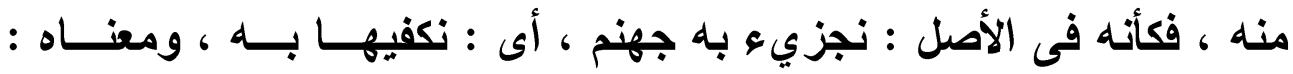

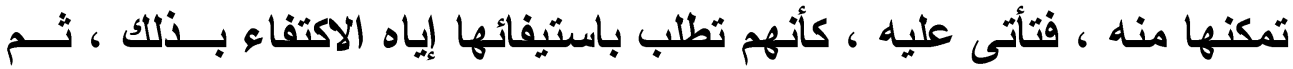

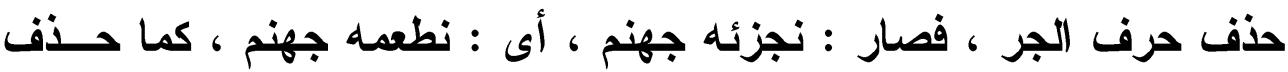

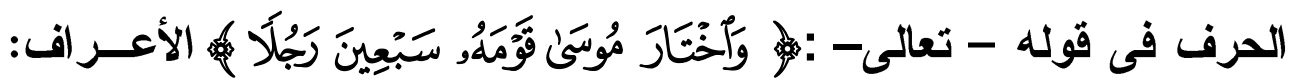

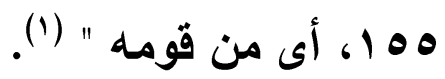

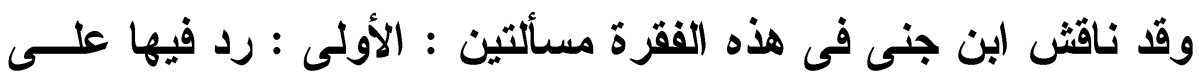

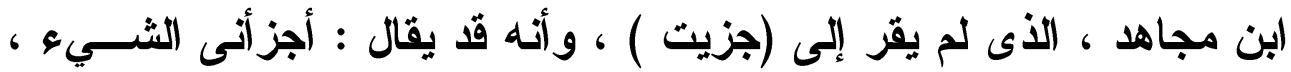

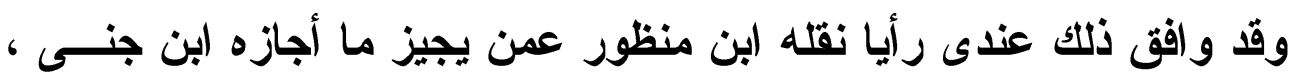

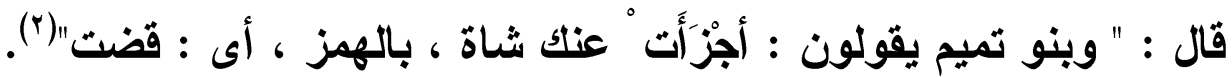
كما نقل عن الزجاج فى كتابه : ( فعلت وأفعت ) : " وجزت عنك شاة

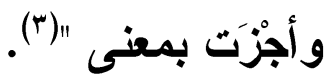

وعن ابن الأعرابى : " وأجزى الثيء عن الثيء : قام مقامه ، ولــــ يكف " (๕)

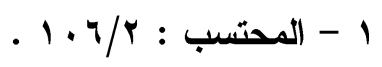

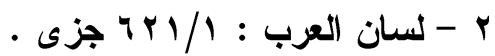

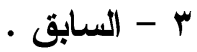

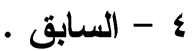




\section{الترقيم الدولخ}

ISSN 2356-9050

بل سبق إلى ذلك المعنى ثُعب ، قال - نقلا عن اللحيانى - : " البقرة

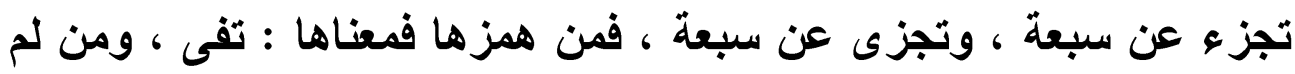
يهمزها تكون جزاء عن سبعة " (1). ومن بعده ابن القوطية : " وجزيتك جزاء : كافأتك بفعلك مـن خيـر أو شر ، وأجزيت عنك : قمت مقامك " (؟). هكذا ، وعلى غير ما ذهب إليه ابن مجاهد ، مع الإثارة بمدى موافقة ما ذهب إليه (بن جنى لمذاهب اللغويين و النحاة . الثانية : حذف الحرف ، وهى مسألة أفاض فيها ابن جنى فى أكثر من

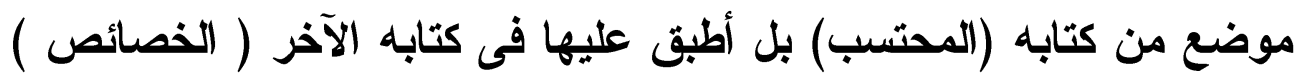
وفى إطار حليثه عن الحذف بصفة عامة، بل لم يكن وحده المعنى بإقرارهذا

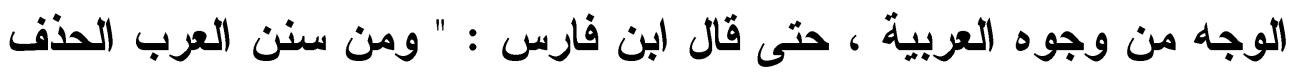

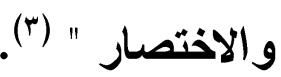

بل أفاض (بن الثجرى فى ضرب الأمثلة التى تبين لنا - وبوضوح تفشى هذه الظاهرة فى لغة العرب ، حتى نص على نفس فلى الآية التى استعان

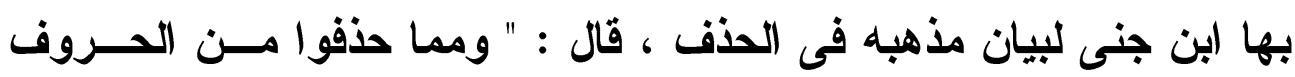

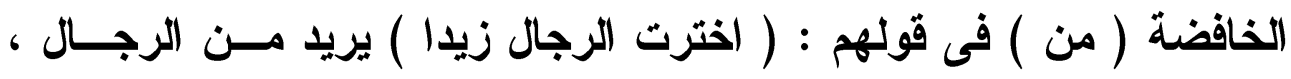

- مجالس ثعلب : ثعلب ، تحقيق : عبدالسلام محمد هارون ، دار المعارف - القاهرة ، ط(ץ)

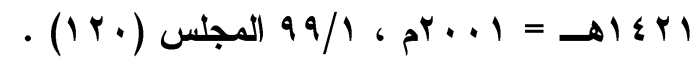

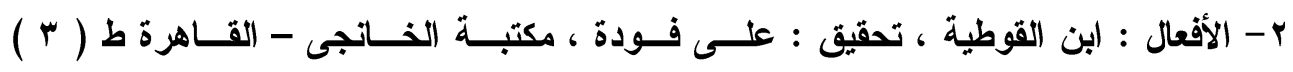

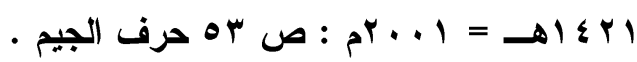
r- الصاحبى فى فقه اللغة العربية : ابن فارس ، تحقيق : د د ـ ـ عمر الطباع ، مكتبة المعارف -

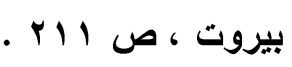

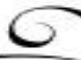


وجاء فى التنزيل : ( واختار موسى قومــه سـبعين رجـلا ) ، أى : مسـن

" أبدلت الهمزة من ( نجزئهه ) ياء ، على حد أخطيث وقريث ، فصارت ياء ساكنة : (نجزيه) وأقرت الهاء على ضمتها ، وهو الأصل ، كما قرأ أهل أهل

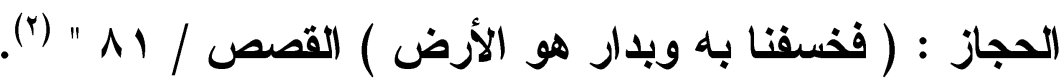
وهنا استعرض ابن جنى ظاهرتين صوتيتين :

1- الأولى: ظاهرة الإبدال، إبدال الهمزة ياء، على نحو : أخطيت وقريت . r- و الثانية : الإبقاء على حركة الهاء بالضم ، وعلى نحو ما مر فى آيــة

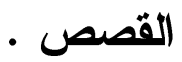

أما إبدال الهمزة ياء إذا كاتت مضمومة ، وقبلها ضــمة ، أو كسـرة

فإتك تصير ها بين بين ، وهو قول العرب ، وقول الخليل ().

1 - أمالى ابن الشجرى : ابن الثجرى ، تحقيق د ـ ـ محمود محمد الطناحى ، مكتبة الخانجى -

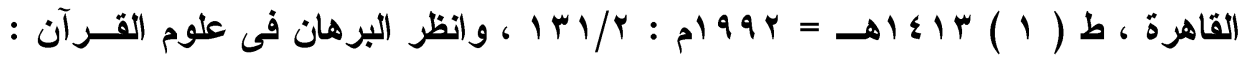

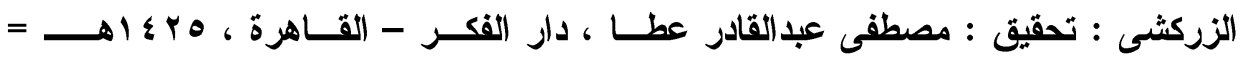

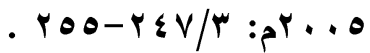

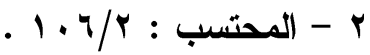

r - انظر : سر صناعة الإعراب : ابن جنى ، تحقيق : أحمد فريد أحمد ، المكتبة التوفيقية -

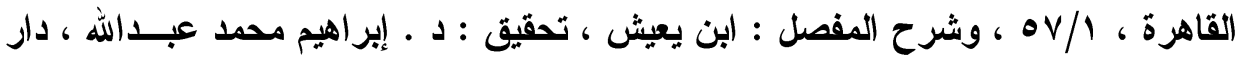

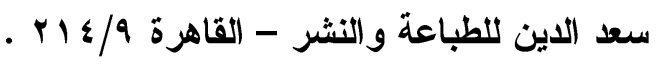




\section{الترقير الدولخ}

ISSN 2356-9050
(1) 119
حولية كلية اللفة العربية بجرجا

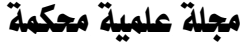

قال سييويه : " و إذا كانت الهمزة مضمومة ، وقبلها ضمة أو كسرة ،

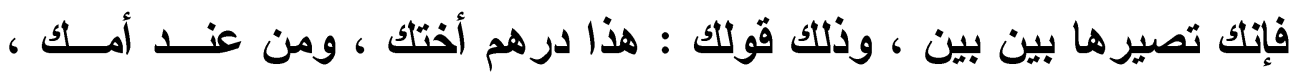
وهو قول العرب ، وقول الخليل " (1).

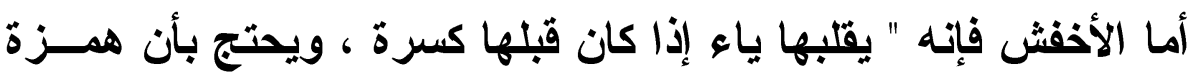

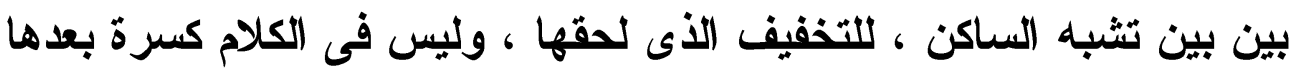
واو ساكنة ـ قال : فلو جعلت بين بين لنحى بها نحو الواو الساكنة ، وقبلها

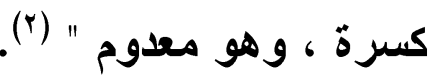

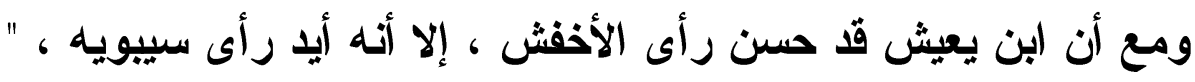

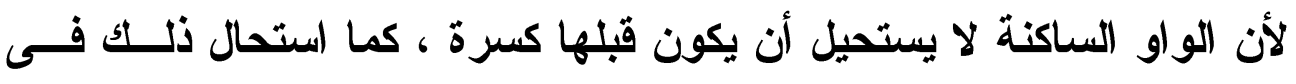

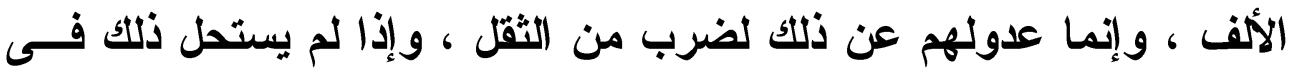

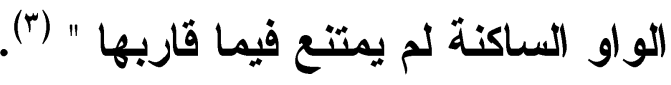

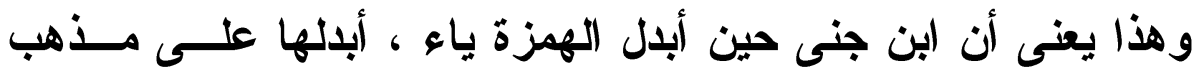

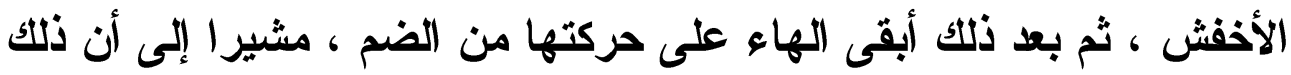

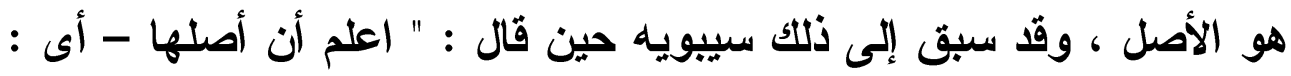

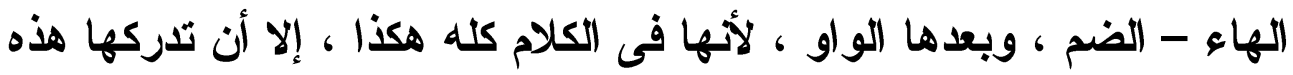

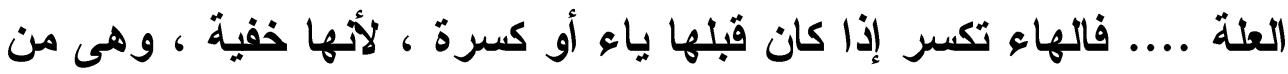
حروف الزيادة ، كما ان الياء من حروف الزيادة " (؛).

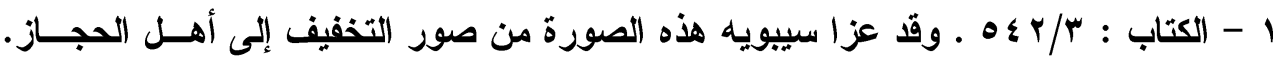

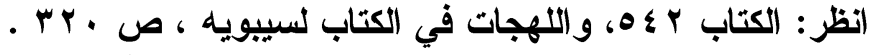

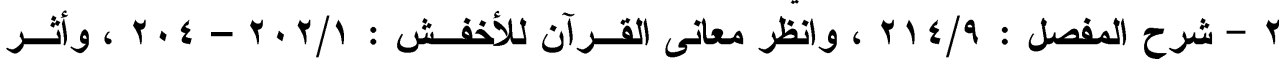

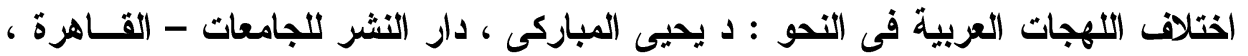

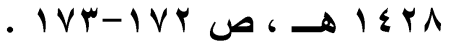
r

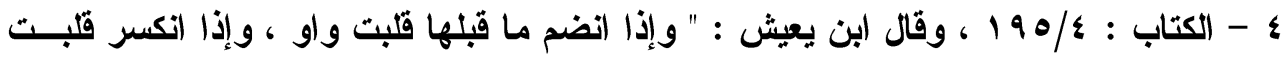

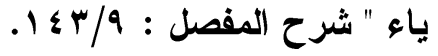

\section{0}


مناقشة ابن جني (بrar)

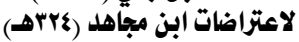

على بعض الروايات في الماحتسب مئ

غير أن ابن جنى قدر ضم هذه الهاء من ( نجزيه ) على الــرغم مـن

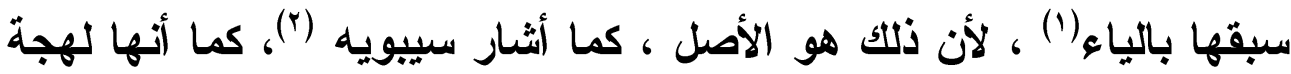

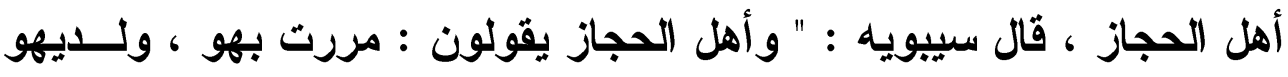

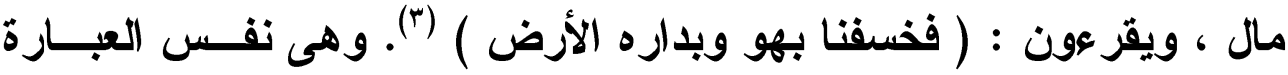

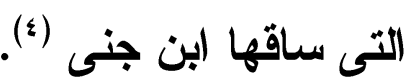
وعلى هذا قول الثـاعر : يعلى بن الأحول الأزدى ، وهو من الطويل:

فَظَلَتُ للدى البيت العتيق أُخَيَلْهُهو

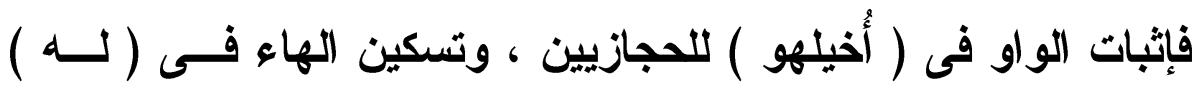

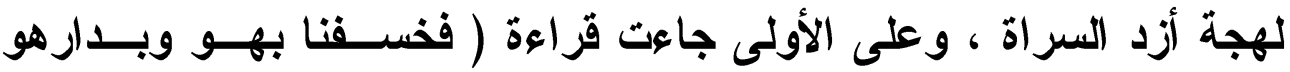

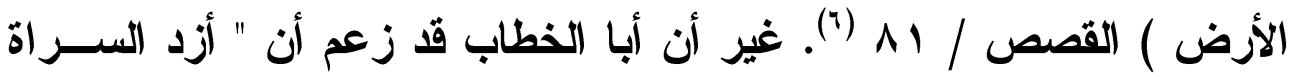
يقولون: هذا زيدو، وهذا عمرو، ومررت بزيدي وبعمري، جعــوه قياســا واحا فأثبتوا الياء و الو او كما أثبتوا الألف" (V) قال ابن جنى : " وزاد فى حسن الضمة هنا أن الأصل الهمز ، والهــاء

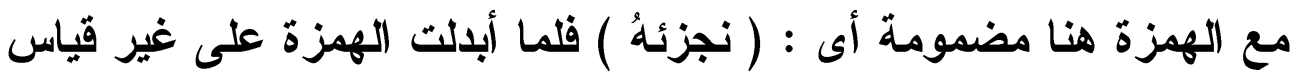

$$
\begin{aligned}
& 1 \text { - المحتسب : } 1 / \% \\
& \text { r } \\
& \text { r - السابق - المدئ : } \\
& \text { ع - المحتسب : }
\end{aligned}
$$

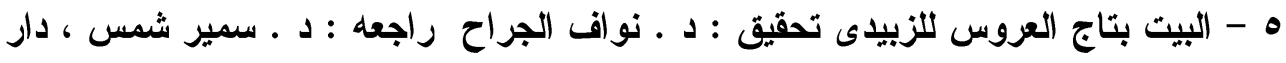

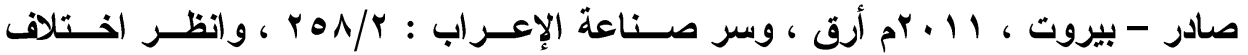

اللهجات العربية فى النحو : د ـ يحيى المباركى ص . IV . . .

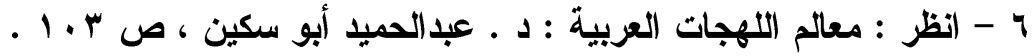

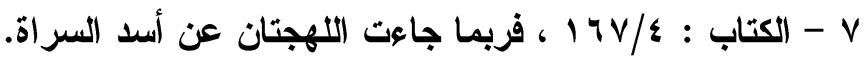




\section{الترقيم الدولخ}

ISSN 2356-9050

صارت الهاء كأنه لا ياء قبلها ، لأنه ليس هنا مسوغ للهمز لولا حمله على في

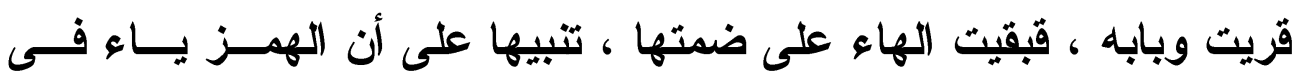

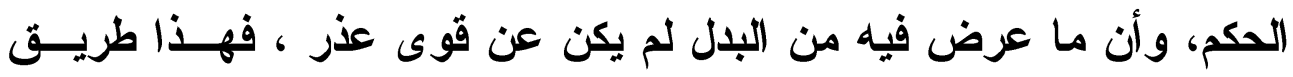

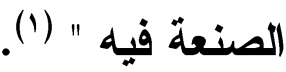

وقال : " فإن رأيت الهمزة وسطا أو آخرا ، فاقض بأنها أصل " (؟).

وعبارة ابن جنى هذه تعكس جملة من الحقائق :

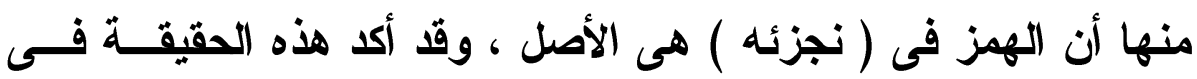

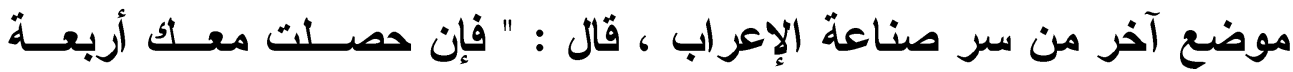

أحرف أصول ، و الهمزة فى أولها ، فاقض بأن الهمزة أصل " (").

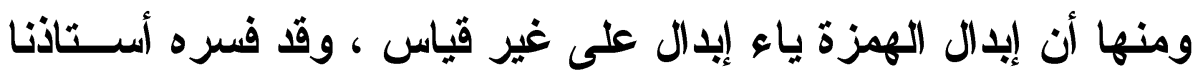

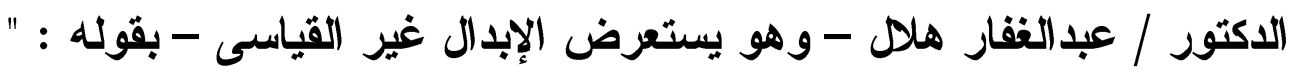

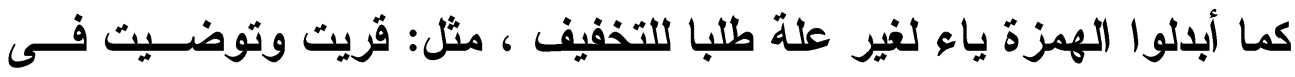

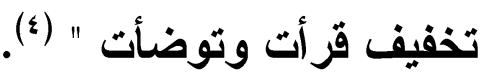

ومنها أن الهمزة لما أبلاكت ياء على غير قياس صارت الهاء كــأن لا

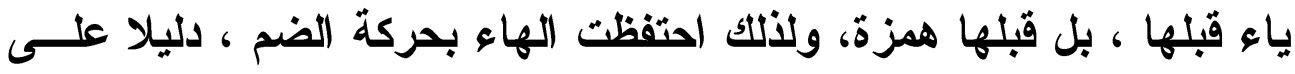

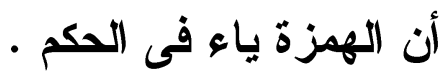

$$
\begin{aligned}
& 1 \text { - المحتسب : } 1 / \% \\
& \text { r - r السابق - r }
\end{aligned}
$$

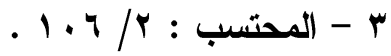

$$
\begin{aligned}
& \text { ع - اللهجات العربية : ص • •rr . }
\end{aligned}
$$




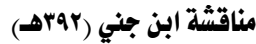

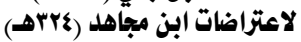

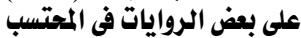

V ومما عارض فيه ابن مجاهد ابن جنى ما ورد فى قولــه - تعـالى - :

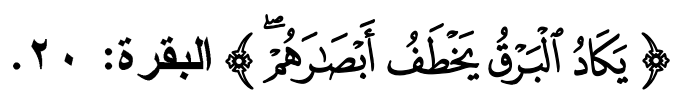

قال ابن جنى : " ومن ذلك ما حكاه الفراء عن بعض القراء ، فيما ذكر

ابن مجاهد ( يَخَطَّفُ ) بنصب الياء و والخاء و التثديد " (1).

وقد اعترض ابن مجاهد على هذه القزاعة ، قائلا : " ولم يرو لن عن

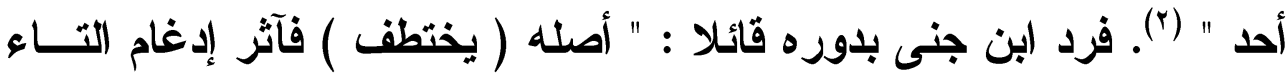
فى الطاء ، لاتهما من مخرج واحد ، ولأن التاء مهموسة ، و الطاء مجهورة

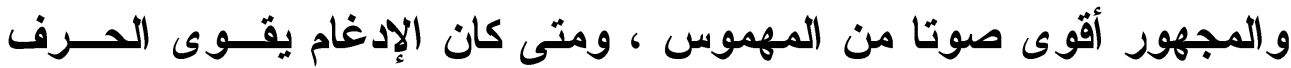

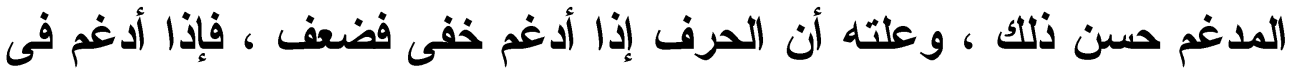
حرف أقوى منه استحال لفظ المدغم إلى لفظ المدغم فيه فقوى لقوته ، فكأن فى ذلك تدارك وتلاف لما جنى على الحرف المدغم ، فأسكن التاء لإدغامها،

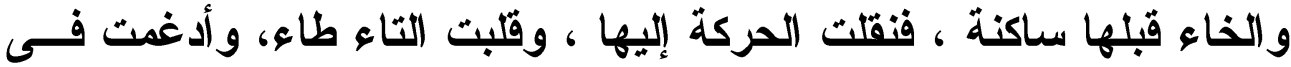

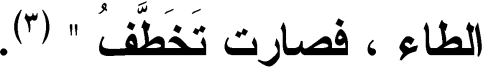

قال ابن مجاهد : " وحكى الفراء أن بعض أهل المدينة يسـكن الخــاء

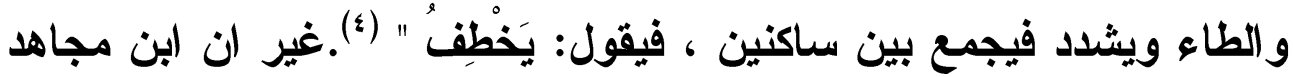

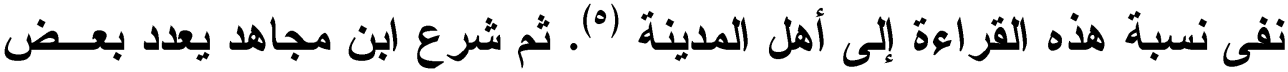

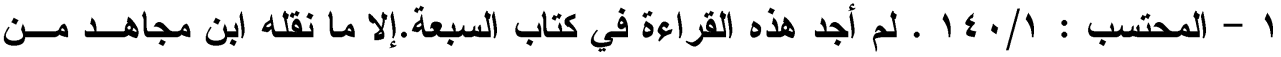

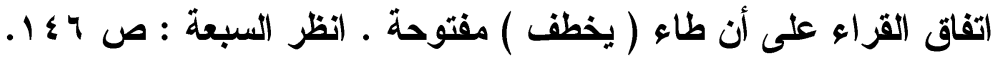

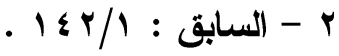

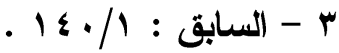

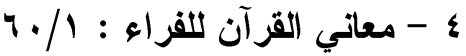

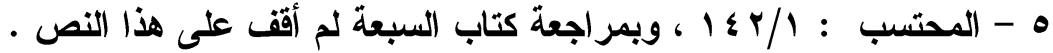




\section{الترقير الدولخ \\ ISSN 2356-9050}

القزاعات ويردها ، قائلا : " وقد روى عن مجاهد والحسن ( يخطِفُ ) ولــو لم يبلغنا أن أحدا قرأ ( خطف ) بفتح الطاء ، فيقرأ هذا الحرف ( يخطِـف )

وأحسب أن هذا غلط ممن رواه"(1).

فالدرس الصوتى هنا يتمثل فى ما حكاه الفراء عـن بعـض القــراء

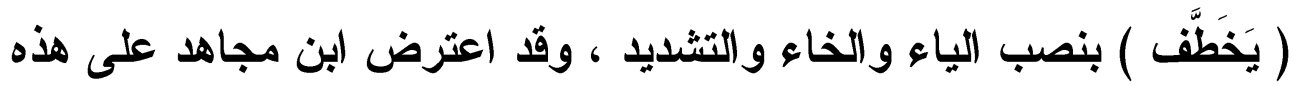
القزاعة ، قائلا : " ولم يرو لنا عن أحد " . فثرع ابن جنى يدلل على صحة

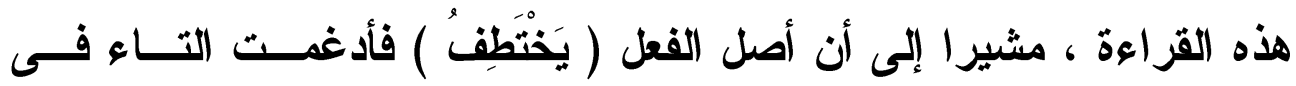
الطاء، لأنهما من مخرج واحد ، مما بين طرف اللسان وأصول الثنايا (؟). كما ذكر ابن جنى من دواعى الإدغام أن " التاء مهموســـة ، والطــاء مجهورة ، والمجهور أقوى صوتا من المهموس ، ومتى كان الإدغام يقوى الحرف المدغم حسن ذلك " ().

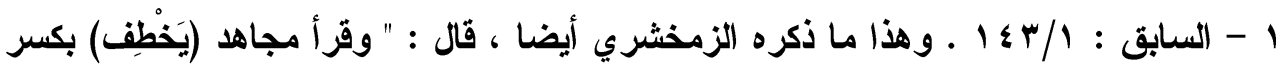

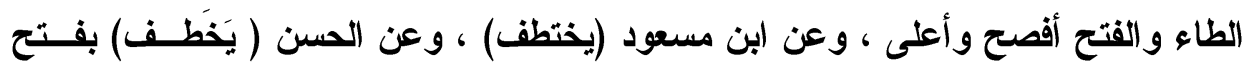

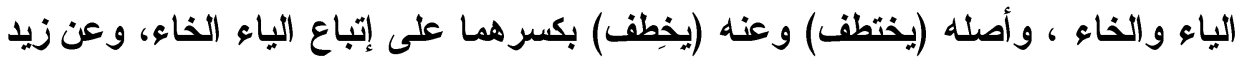

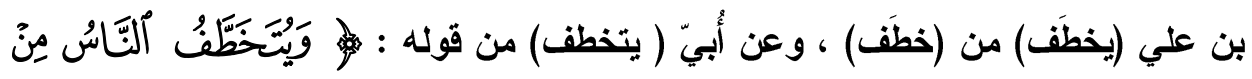

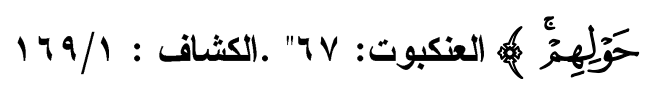

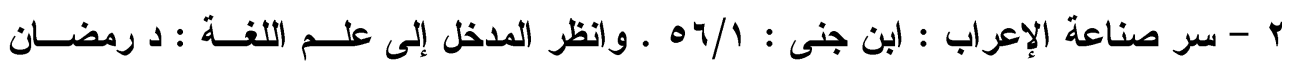

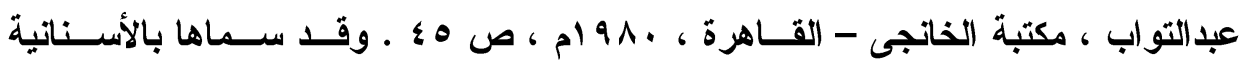

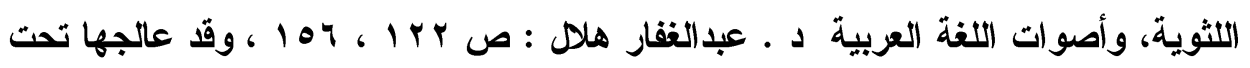

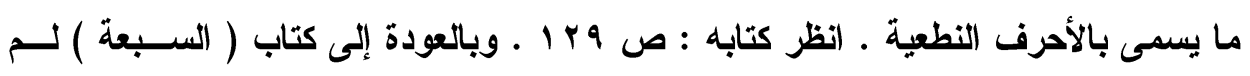

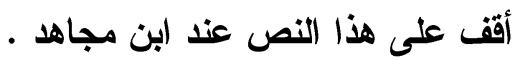

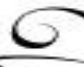


مناقشة ابن جني (بrara)

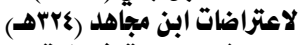

على بعض الروايات في المحتسب إنب

وقد واققه المحدثون فى همس التاء (')، غير أنهم خالفوه فى وصــف

الطاء ، فقد وصفها الأقدمون بالجهر (ז)، ووصفها المحدثون بــالهمس ، "

باتفاق فى نطقتا الحالى ، ونطق قراء القرآن الكريم فى مصر الآن " ("). وليس معنى هذا " أن أحد الفريقين تجاوز الصواب فى رأيه بـل كـلـ

منهما مبنى على أساس النطق الأى وصل إليه " (๕).

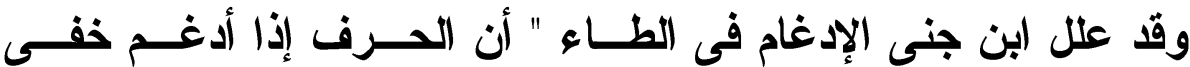
فضعف، فإذا أدغم فى حرف أقوى منه استحال لفظ المدغم إلى لفظ المــدغم فيه فقوى لقوته " (•). وهى عبارة قريبة المعنى من عبارة ابن الجزرى ، وهو يشـير إلـى تعريف الإدغام : " فهو عبارة عن خلط الحرفين ، وتصييرهما حرفا واحـــا مشددا ، وكيفية ذلك أن يصير الحرف الأى يراد إدغامه حرفا واحدا علـى صورة الحرف الأى ياغم فيه ، فإذا تصير مثله حصل حينئذ مستخلان ، وإذا حصل مثنلان وجب الإدغام حكما إجماعيا " ("). وهذا يعنى النطق بالحرفين حرفا كالثانى مشددا ، بل يترتب على ذلك أن يقوى الحرف المدغم فيه ، ويخفى المدغم فيسكن ، كما سكنت التاء هنا لإدغامها ، وقبلها الخاء ساكنة ، فنقلت الحركة إليها حركة الفتحة ، وقلبث

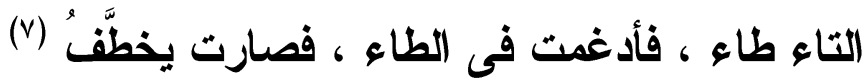

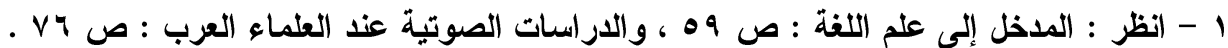

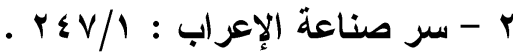

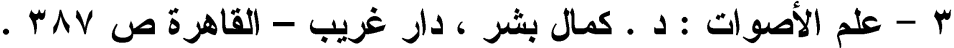

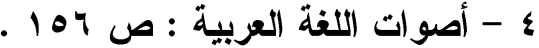

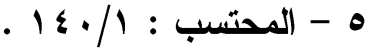

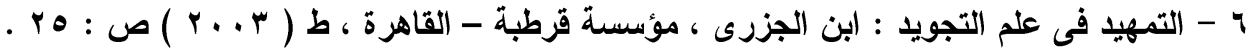

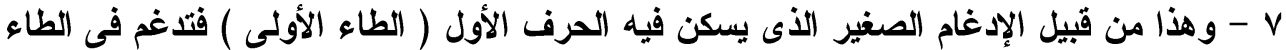

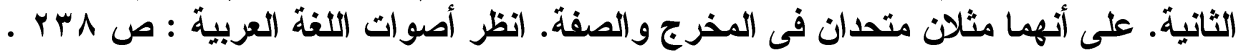

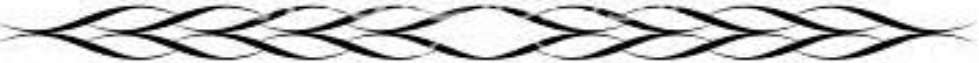




\section{الترقير الدولخ}

ISSN 2356-9050 (110r

حولية كلية اللفة العربية بجرجا مجلة علمية محكمة

وهذا النوع من الإدغام الأى سكن فيه الحرف الأول ، وحرك الثانى ، إدغام واجب (1). هذا ، وقا أثثار السمين الحلبي إلى تلـــك القـــراعة التــي أوردها ابن مجاهد ، قال: " يخطف ، بقتح الياء والخاء والطاء مـع تثــديد الطاء، والأصل يختطف ، فأبدلث تاء الافتعال طاء للإدغام" (ז). كما نقل ابن مجاهد حكاية القزاء أن بعض أهل المدينة يسكنون الخاء و الطاء ويشددون فيجمعون بين ساكنين(ז) ، غير أنه نفى علمه برواية هذه القراعة ، الامر الذى استوجب ردها ، قال: " ولا نعلم أن هذه القراعة رويت

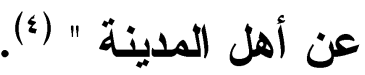
وعبارة ابن مجاهد هذه لا تحسم الأمر لعدة وجوه : الأول : أن انتفاء علمه بهذه الرواية لا يعكس - بالتأكيـــ - انتفــاء روايتها ، وقد رأينا البعض فى (إعراب القرآن ) يثبت هذه الرواية نقلا عن

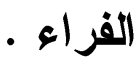

الثانى : أنه ما دام للقراعة مسوغ لغوى فما يمنع من طرحها ؟ . وقد شرع ابن جنى يفند مصوبا هذه القراعة ، ويؤصل لنطقها ، غيــر أنه حمل ما أجازه الفراء من اجتماع ساكنين ، وما يترتب على ذلـــــــن تحقيق الإدغام ، على أنه اختلاس وإخفــاء لا إدغــام ، "إخفــاء للحركـــة

$$
\begin{aligned}
& 1 \text { - التمهيد فى علم التجويد. ص هr } \\
& \text { r - الدر المصون: VN/1 }
\end{aligned}
$$

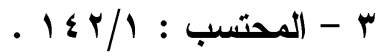

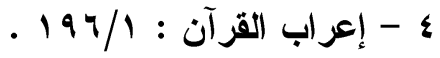


و إضعاف للصوت " (1). وكأن ابن جنى يريد أن يقول : إن القراعة ها هنــا

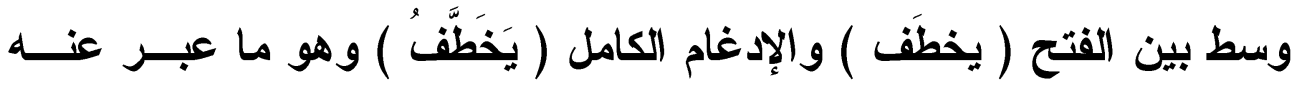

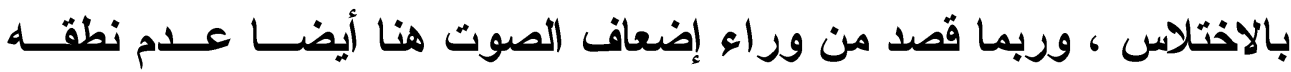

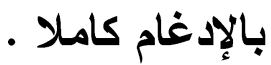

و استذل على ذلك بقول رؤية بن العجاج :

وَمَسنْحِه مَرْ عقاب كاسر

كما أنثده سييويه شاهدا على إدغام الهاء فى الحاء بلقظ ومسحى مرُّ عقابٍ كاسرِ

\section{كأنها بعد كلال الزاجر}

يريدون : ومَسْحه (").

و الثشاعر هنا يأكر ناقة ، يقول فيها : كأنها بعد طول السـير وكــلال

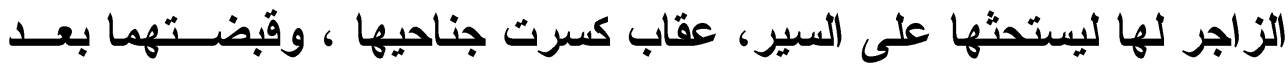

انقضاضها ، والمسح هنا عبارة عن ذرع الأرض بالسير (؛). قال فى اللسان : " يريد ومَنْحِهِ ، فأخفى الهاء " (•).

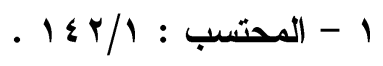

r - البيت باللسان : rNV乏/0 كسر ، وصدره ( كأنها بعد كلا الزاجر ) أراد : كأن مرها مر

$$
\text { عقاب . }
$$

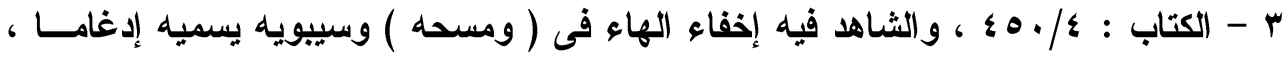

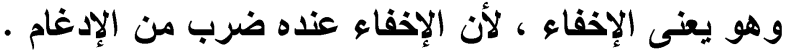

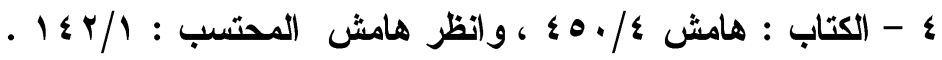

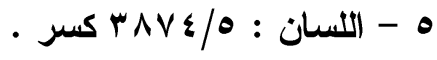




\section{الترقير الدولخ}

ISSN 2356-9050

قال ابن جنى : " قال سييويه كلاما يظن به فى ظاهره أنه أدغم الحاء

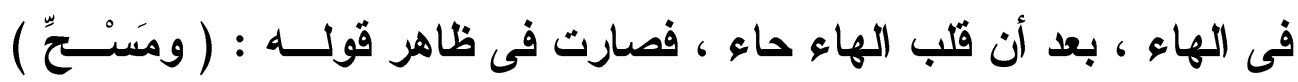
واستدرك أبو الحسن ذلك عليه ، وقال : إن ذلك لا يجوز إدغامه لأن السين

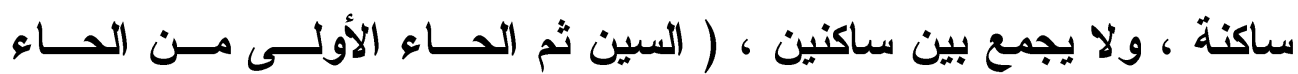
المشددة) قال : فهذا لعمرى تعلق بظاهر لفظه ، فأما حقيقة معناه فلم يــرد

محض الإدغام " (1) - (1)

وهذا ما أكد عليه ابن جنى مرة أخرى فى كتاب ( المحتسب ) إذ يقول:

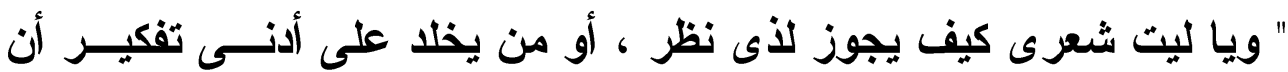
ياعى أن هنا إدغاما ، أو أن تجمع بين ساكنين"(r). بل لجأ ابن جنى إلى علم العروض لتقرير هذه الحقيقة التى اقتنع بهـــا إلى حد بعيد ، قال : " ألا تزى إلى قوله ( ومسحهى ) مفـــاعلن ، فالحـــــاء مقابل بها عين ( علن ) والعين أول الوتد (r)، وهى كما ترى وتعلم محركة ، أفيقابل فى الوزن الساكن بالمتحرك ؟ " (؛). لا ، بل الساكن بالساكن ، والمتحرك بالمتحرك .

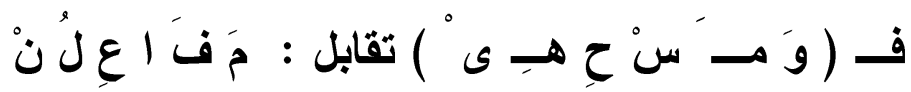

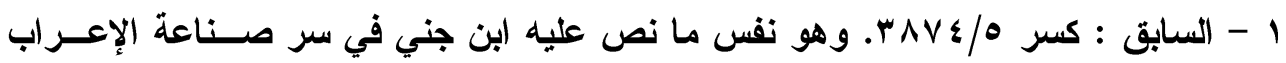

$$
\text { r }
$$

r - و الوتد هنا وتد مجموع ، وهو ما تكون من حركتين بعدها ساكن ـ انظر موسيقى الشعر

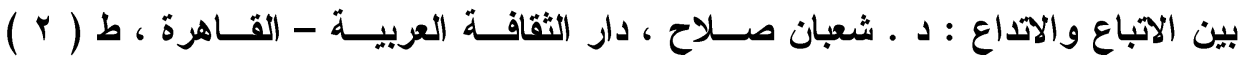

$$
\text { • }
$$

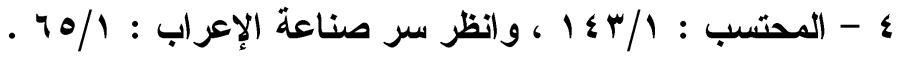


فالحاء المتحركة تقابل العين المتحركة ، ومن ثم فلا إدغام .

ثم اعترض (بن مجاهد على قراعة مجهاد والحسن ( يَخْطِفُ ) قال : "

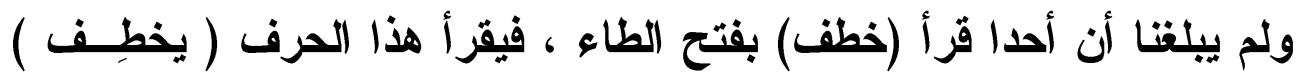
وأحسب أن هذا غلط ممن رواه " (1).

وقد أكد الأخفش توجيه (بن مجاهد فقال - تعقيبا على القــراعة - : " وهى قليلة رديئة لا تكاد تعرف " (†).

و إلى مثل هذه اللغة الردئية أثثار ابن منظور فى اللسان ، وذلك فـى

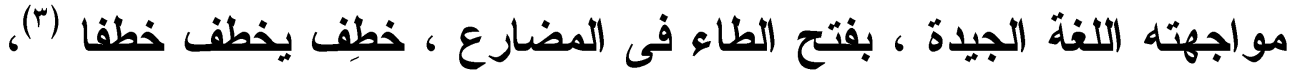

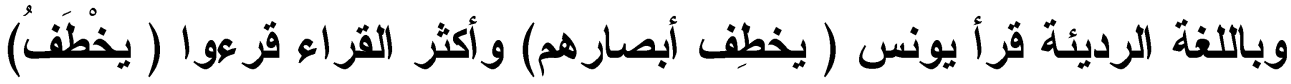

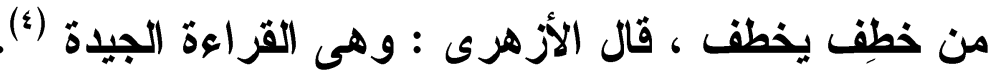
وهذه العبارة للأزهرى لا تعكس سقوط هذه اللغة ، بقدر ما تثبتها لغة أخرى إلى جوار لغة الفتح ، وهذا ما نص عليه الأزهرى حين قال : " خطفٍ يخطَف ، وخطِف يخطِف لغتان " (॰).

1 - السابق. لم أقف على شيء من هذا في كتاب (السبعة ) لابن مجاهد .

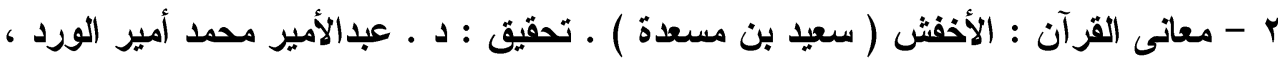

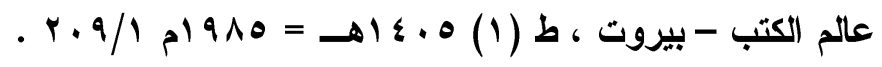

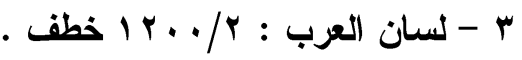

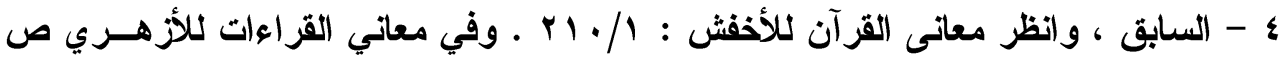

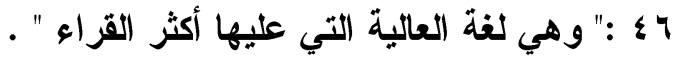

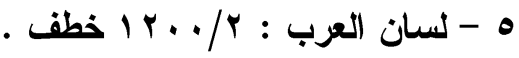




\section{الترقير الدولخ \\ ISSN 2356-9050}

- - كما اختلفوا فحى قوله - تعالى - :

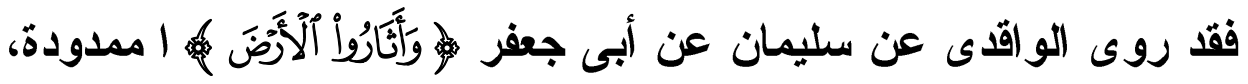
فاعترض ابن مجاهد على هذه القراعة ، قائلا : " ليس هذا بشيع " . قال أبو القتح : " ظاهره لعمرى منكر ، إلا أن لله وجها مـــــ ، ولــيس لحنا مقطوعا به ، وذلك أنه أراد : وأثاروا الأرض ، أى : شققوها للغــرس إنس

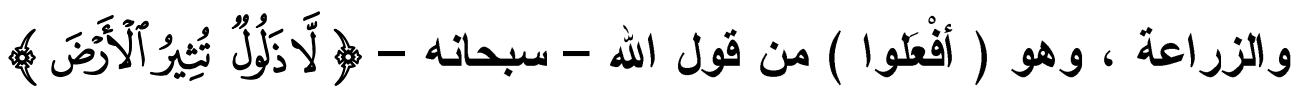

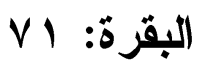

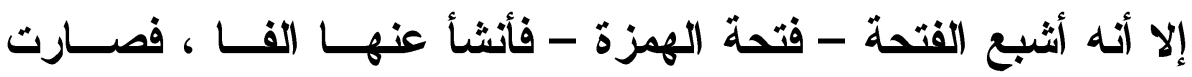
(آثاروا) وقد ذكرنا ذلك وشواهده فى نحو قول ابن هَرْمة ، وهو من الوافر:

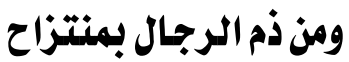
فأنت من الفوائل حين ترمى يريد : بمنتزح ، مُنْفَعل من النازح ، فأشبع فتحة الزاى ، فأنشا عنهــا ألفا وهذا لعمرى مما تختص به ضرورة الشعر ، لا تخير القزآن " (1).

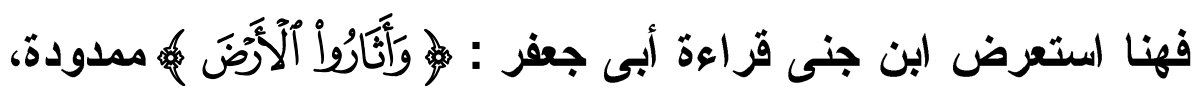
وقد اعترض ابن مجاهد على هذا المد فقال : " ليس هذا بشيع "("). ثُم عاود ابن جنى دفاعه عن هذه القزاعة ، لا من باب أنهـــا قــراعة

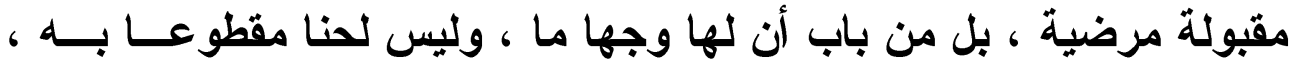
وذلك أنه أراد : وآثاروا الأرض ، أى : شققوها للغزس والزر اعة ، وهــو

$$
\text { ا } 1 \text { - المحتسب : }
$$

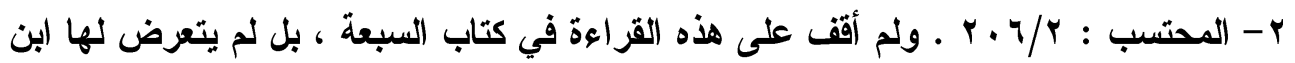




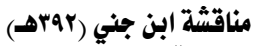

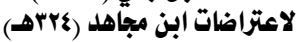

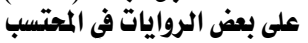

( أفعلو ) من قول الله - سبحانه - ( ذلول تثير الأرض ) (') إلا أنه أثــبع

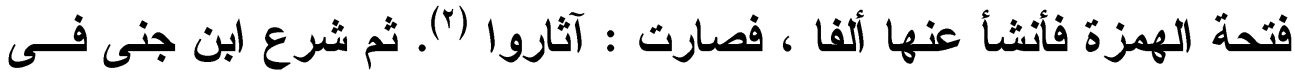

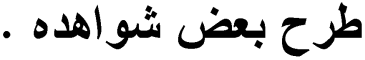

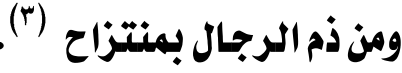

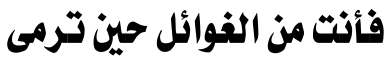

يريد : بمنتزح ، منفعال من النازح ، فأثبع فتحة الزاى ، فأنشأ عنها

ألفا ، وهذا مما تختص به ضرورة الثعر لا تخير القرآن (\&).

ثُم أكلا (بن جنى على هذا الفهم في كتابــهـ ( الخصــائص ) ، فقــال :

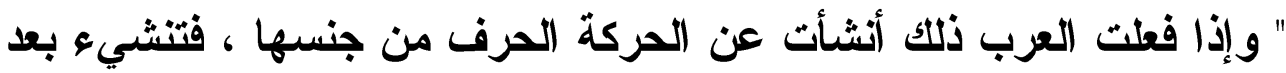
الفتحة الألف ، وبعد الكسرة الياء ، وبعد الضمة الواو " (॰). ولم يتوقف فى الخصائص على شـاهد ابن هرمة ، الــــى ســاقه فــى (المحتسب) بل دعمه بشواهل أخرى ، كثاهد عنترة :

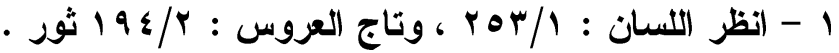

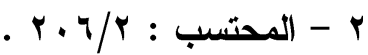

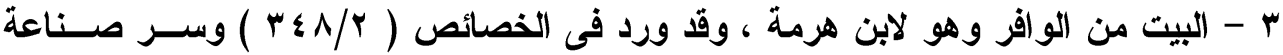

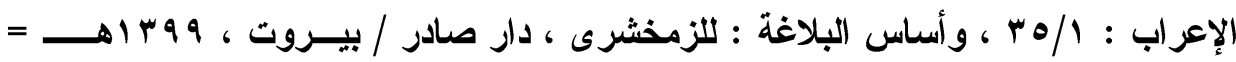

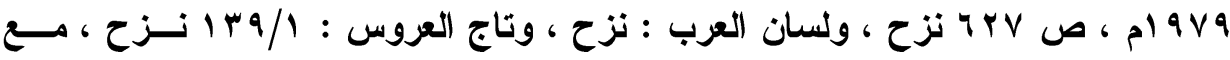

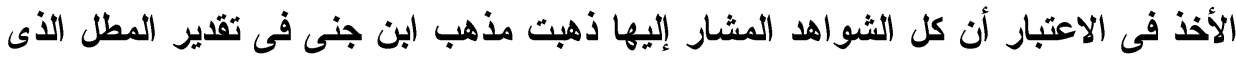

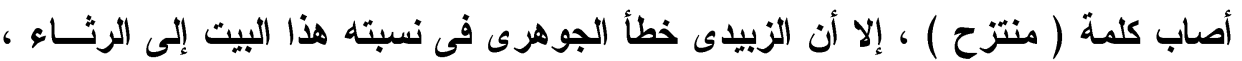

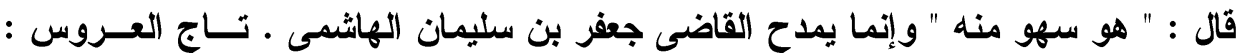

$$
\begin{aligned}
& \text {. }
\end{aligned}
$$

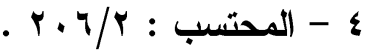

$$
\begin{aligned}
& \text { 0 - الخصائص : }
\end{aligned}
$$




\section{الترقيم الدوله ISSN 2356-9050}

\section{ينباع من ذفرُرَى عَضُوبِ جَسرةٍ (1)}

بل ساق قولا للأصمعى يدعم به مذهبه : " وقال الأصــمعى : يقــال : انباع الشجاع ، ينباع انبياعا، إذا انخرط بين الصفين ماضيا " (r). بل عقد ابن جنى لمطل الحركات فصلا كاملا فى ( الخصائص ) ســماه (باب فى مطل الحركات)(ّ) يدلل به على ذر اعه السامقة فى هذا الفن .

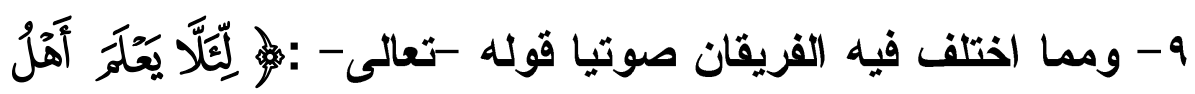

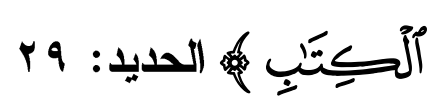

فقد قر أها الحسن : ( لَيْلا ) بنصب اللام ، وبجزم الياء ، ولا يهمــز ،

$$
\text { وهذا ما أقره (بن مجاهد(). }
$$

قال ابن جنى: "حكاها قطرب، فيما رويناه عنه - (ليلا ) بكسر اللام، وسكون الياء ، وقال : حذف هزة أن ، وأبدل النون ياء هكذا قال" (•).

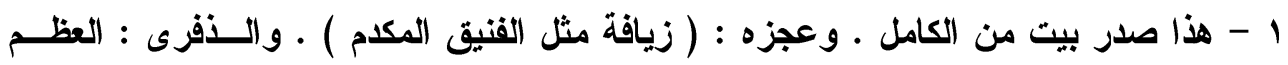

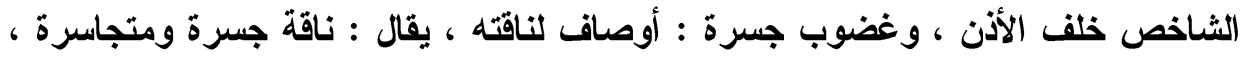

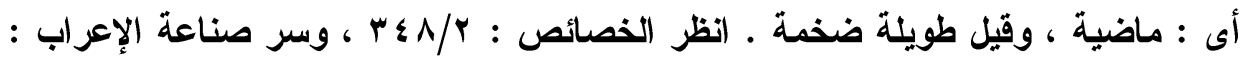

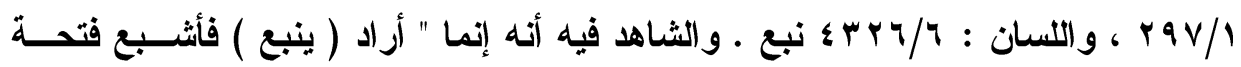

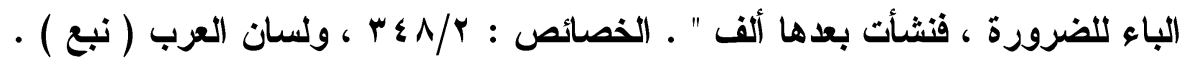

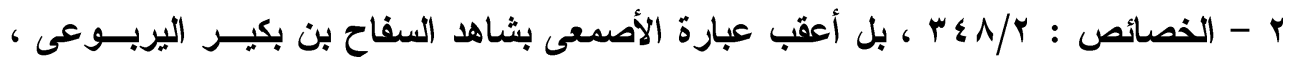
وهو من السريع:

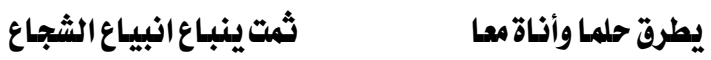

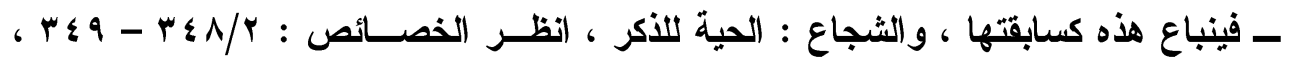

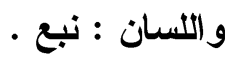

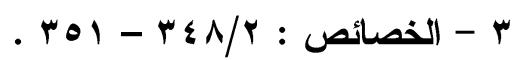

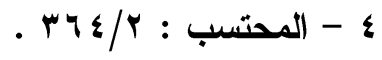

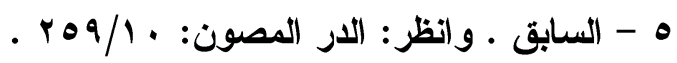




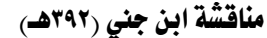

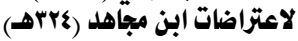

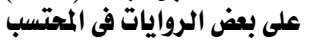

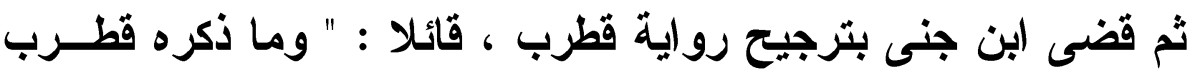

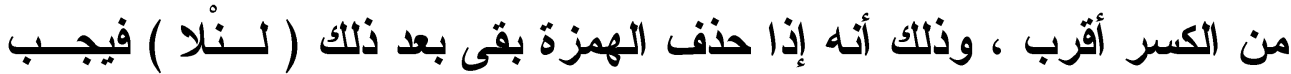

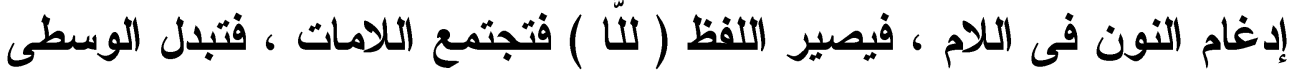

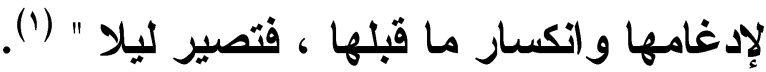
وهنا تعارض رأيا (بن مجاهـا وقطرب ، حول هـــه الآيــة ، وقــــاعة الحسن،: ( ليلا يعلم أهل الكتاب) بنصب اللام ، وبجزم الياء ، وبغير همز (†).

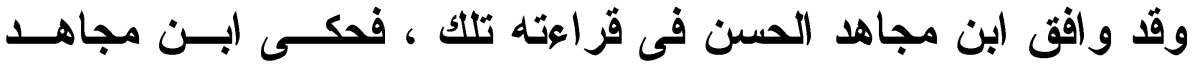

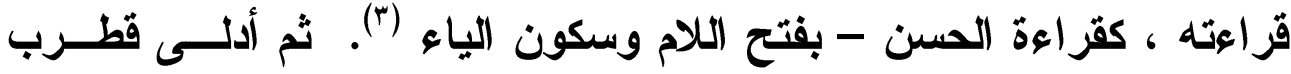
برواية نقلها ابن جنى : ( ليّلا ) ) بكسر اللام وسكون الياء ، ثم حذف هــــة

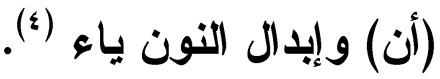
وما كان من ابن جنى إلا أنه رجح قراءة قطرب عـى قــراءة ابــن مجاهد، ومن قبله الحسن ، فقال : " وما ذكره قطرب من الكسر أقرب " (•). ثم شرع ابن جنى يؤصل لقراعة قطرب ، بحذف الهمزة أولا ، فتصير

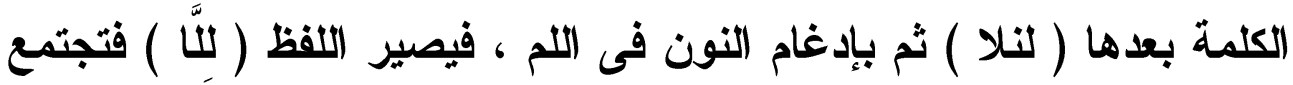
اللامات ثم تبدل اللام الوسطى ياء لإدغامها وانكســار مـــا قبلهـــا فتصــير (ليلا)("). وتقدير المعنى عند الزمخشرى : لئلا يطــم ، أى : لــيطلم اهـل

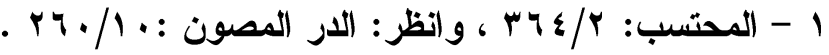

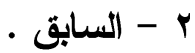

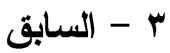

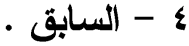

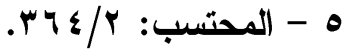

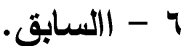

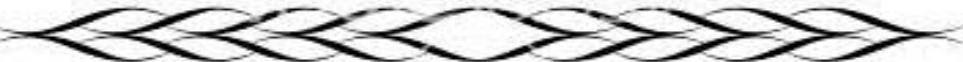




\section{الترقيم الدوله \\ ISSN 2356-9050}

الكتاب، الأين لم يسلموا ، وهذا التأويل مبنى على أســاس أن ( لا ) هنـــا

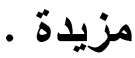

كما ذهب إلى أن ( أن ) ها هنا المخففة من الثقيلة ، ولذلك جاء الفعل بعدها مرفوع بثبوت النون ، وأصله : أنه لا يقدرون ، يعنى أن الثــأن لا

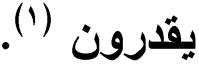

و هذا مذهب الفراء أيضا ، فـ ( لا ) هنا معناها السقوط من الكـلام ،

إذ " العرب تجعل (لا ) صلة فى كل كلام دخل فى آخره جد أو فى أولــه.

جد " (ז) (")

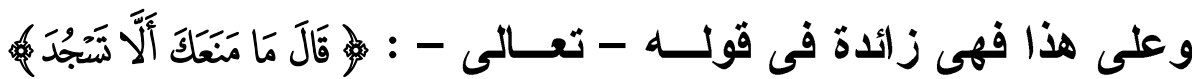

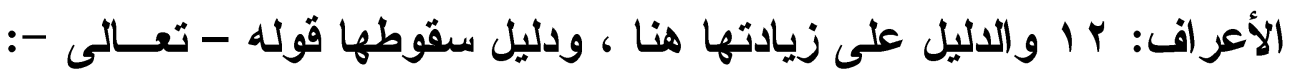

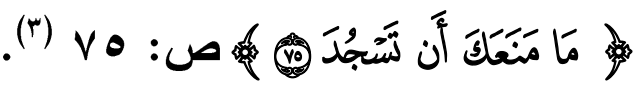
ثم جاء أبو حيان وفرع على الآية فروعا :

الأول: ما ذهب إليه سابقوه من أن (لا) زائدة إذ يقول: "أصله لأن يعلم"(\{).

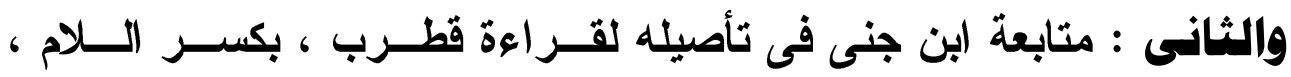
وسكون الياء ، وتوجيهه : حذف الهمزة اعتباطا ، ثم إدغام النون فى اللام ، فاجتمعت الأمثال وثُقل النطق بها ، فأبدلوا من الساكنة يــاء ،

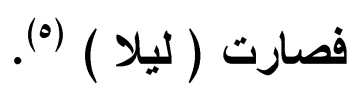

1 $197 / r$ : الكشاف 17

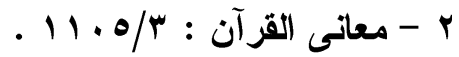

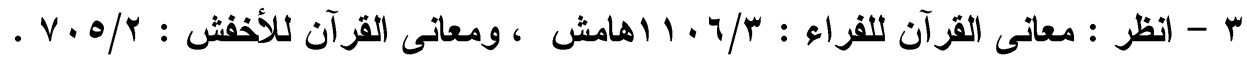

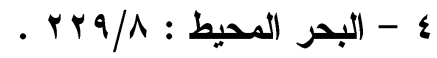


الثالث : أنه لم ير مزيد فرق بين قراعتى ابن مجاهد وقطـرب ســوى فتح اللام عند ابن مجاهد ، وكسرها عند قطرب - وهما فيما سوى ذلك متكافئان فى النص والتأويل ، إلا أن أبا حيان قد حمل كسر الــلام ، علــى اللغة الثهيرة فى لام الجر ، وحمل فتحها على أنه لغة فى الكلام (1). كما أثشار النحاس إلى زيادة ( لا ) فى الآية للتوكيـــ ، ورصـــ عـدة قراعات للآية : لسعيد بن جبير عن ابن عباس ، ولعاصم الجحدى عن ابن مسعود ، كلها محمولة على زيادة ( لا ) (؟r). كما أقصى أبو جعفر النحـــاس قراعة الحسن برفع الميم من قوله - تعالى - : ( لئلا يعلم ) قائلا : " ومسـن الشواذ أنه روى عن الحسن أن قرأ : ( لئلا يعلم أهل الكتاب ) بالرفع (). وعليه فلا فرق بين قر اعة ابن مجاهد وقر اعة قطــرب سـوى حركــة اللام، بالفتح فى قراعة ابن مجاهد ، وبالكسر فى قر اعة قطرب ، وقد حملها أبو حيان على اختلاف اللغات بما لا يشكل خطئا عن هذا أو ذالك ، مع الأخذ فى الاعتبار ان كسر اللام ، إنما هو اللغة الشهيرة فى لام الجر ، كما ذكـر أبو حيان ، وكما أثشار ابن هشام(ع) .

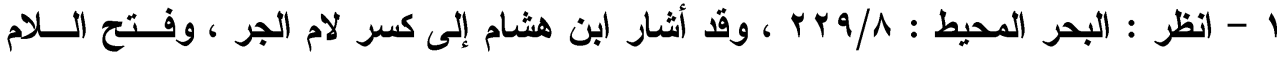
الزائدة ، انظر مغنى اللبيب عن كتب الأعاريب : ابن هشام ، تحقيق ج : الفــاخورى ، دار

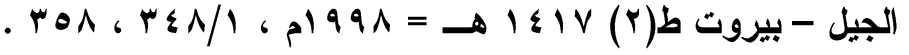

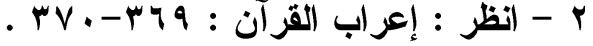

$$
\begin{aligned}
& \text { r - إعراب القرآن : }
\end{aligned}
$$

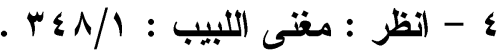




\section{الترقيم الدولم \\ ISSN 2356-9050}

\section{المستوى الصرفي}

وهو مستوى يقوم على ما تؤديه الأوزان الصرفية من معان ، وهو ما

$$
\text { يعنى من وجه آخر الالامة الصرفية. }
$$

وقبل استعراض مظاهر هذه الدلاكة تجدر الإثارة إلى مدى العلاقة بين الصوث والصرف، فقد " ظل البحث الصوتى عند كبار النحاة العرب جـزعا

مكملا للبحث الصرفى " (')

وكذلك العلاقة بين الصوت والنحو إن لم تكن فى تلاك المرتبة فلا تقــلـ

عنها

و إذا كان المستوى الصرفى يختص بلراسة التغيرات التى تطرأ علـى أبنية الأفاظ فتؤدى معان جديدة ، فإن هذه التغيرات هى وحـــات صــوتية سابقة ( يكتب ) أو لاحقة ( كتبث ) أو داخلة (كاتب)ويهذا يتعـين ارتبـاط الارس الصوتى بالارس الصرفى ، والـــرس الصــرفى مقدمــة للــدرس النحوى،لأن اهتمام الصرف ببنية الكلمة إنما هو من أجل توظيفها فى تركيب

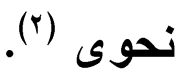
وإذا كانت الالالة الصرفية تقوم على ما تؤديه الأوزان الصرفية مـن معان ، فلا يكفى لبيان معنى (استغفر) بيان معناهـــا المعجمـى المــرتبط بمادتها اللغوية ، ( غ ف ر ) بل لا بد أن يضم إلى ذلك معنـى الصــيغة ، وهى هنا وزن ( استفعل ) أو الأفف والسين والتاء التى تلال على الطلب ().

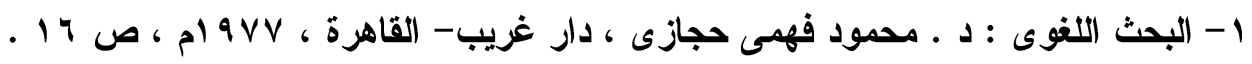

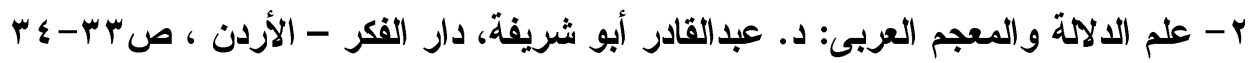

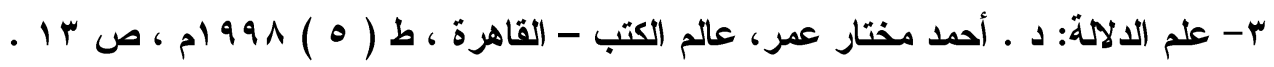

\section{- ) 10}


وعليه فجملة اعثر اضات ابن مجاهد على ابن جنى فى باب الصــرف

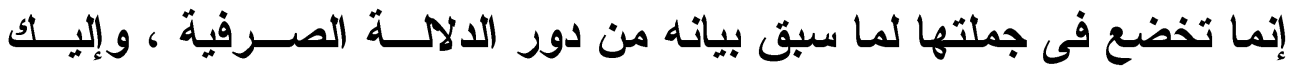
الاعتر اضات على مستوى الصرف .

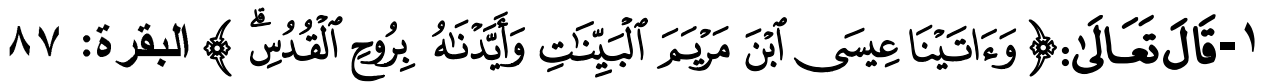

قال ابن جنى : " ومن ذلك ما رواه (بن مجاهد عـن أبـى عمــرو : ( وآيدناه ) قال ابن مجاهد : ممدود الألف ،خفيفــة الياء،وقــــ رُوى عــن

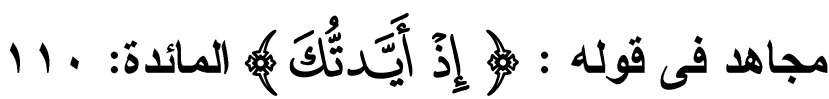
آيدتك ـ قال ابن مجاهد: "على فاعثتك " (1). قال ابن جنى : " هذا الأى توهمه (بن مجاهد - أن ( آيدتك ) فاعلتــأك - لا وجه له ، وإنما (آيدتك) أفعلتك من الأيد ، وهو القوة " (r). خلاصة القول أن الالالة هنا يتقاسمها فعلان :

الأول : آد يئيد أيدا ، إذا الثتا وقوى ، والتأييد مصدر أيدتــهـ ، أى :

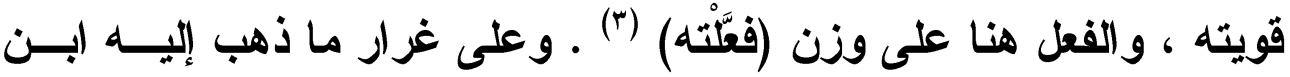
مجاهد (๕)

1 - المحتسب : Vq/ ا ـ وقد نسب ابن مجاهد تخفيف الدال من ( وأيدناه) إلى ابـن كثيـر

$$
\begin{aligned}
& \text { وحده. انظر السبعة ص rآ } 17 \text { ـ } \\
& \text { lV9/r : المحتسب } \\
& \text { r - لسان العرب : 1 1 أيد . }
\end{aligned}
$$

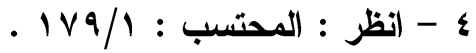




\section{الترقير الدولم \\ ISSN 2356-9050}

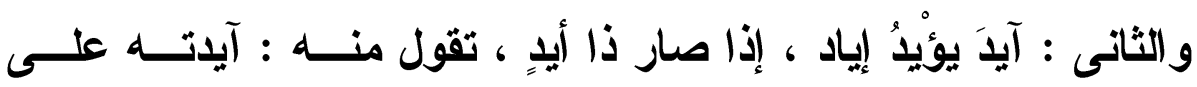

أفعلته فهو موئيد (')

وكأن الهمزة الأولى هزة أفعل ، والثانية فاء الفعل ( أفعل يفعل إفعالا

) وذلك إذا صار ذا أيد، تقول منه : آيدته على أفقلته فهو مؤيد ().

هذا وقد ذكر الزمخثرى فى تفسيره ما يرجح قول ابن جنى ، قال : "

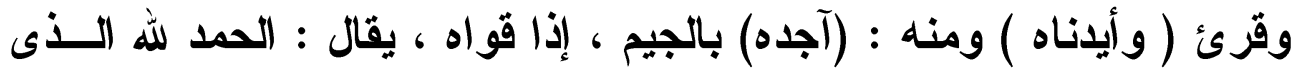

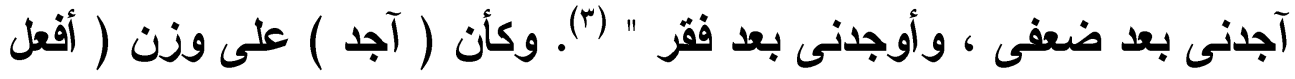

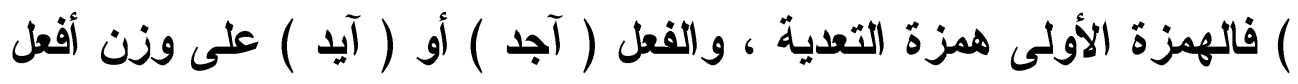

هذا ، وقد استعرض الجوهرى فى الصحاح هذا الفعل ، فقال : " تقول

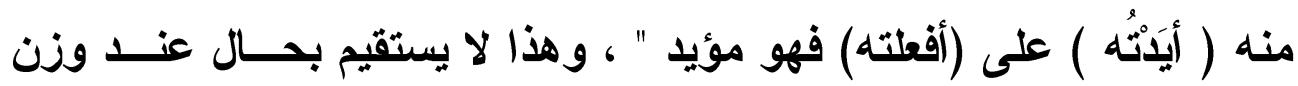

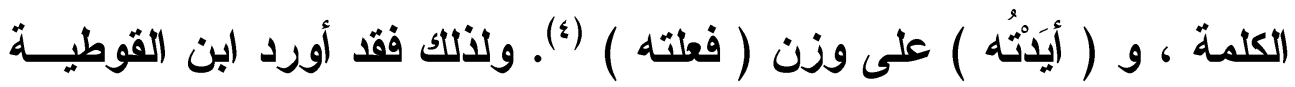

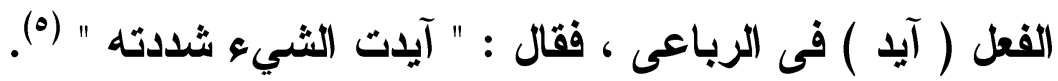

1 - السان العرب : 1 1 أيد

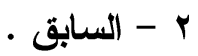

r - الكثاف عن حقائق التنزيل وعيون الأقاويل فى وجوه التأويل الزمخثـرى ، المطبعـة

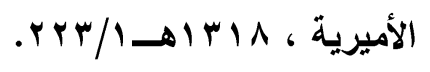

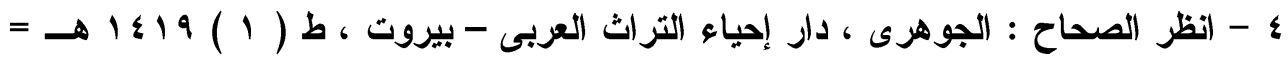

$$
\text { أl }
$$

ه - الأفعال : ص م ب 14 الرباعى ، حرف الهمزة . 
وهنا أورد ابن مجاهد قراعة (بن عباس والحسن يحيـى بـن يعــر

وعاصم الجحرى وأبى رجاء: ( و إله أبيك ) بالتوحيد (1).

قال ابن جنى : " قول ابن مجاهد بالتوحيد لا وجه له ، وذلك أن أكثــر

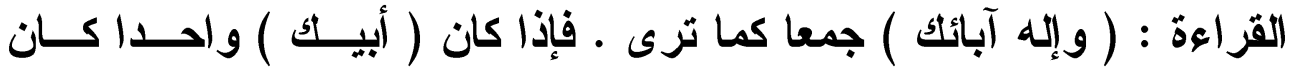

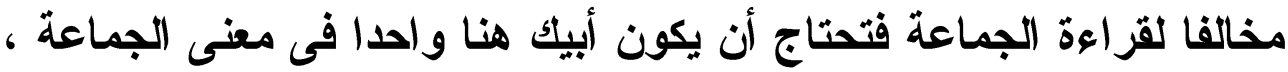

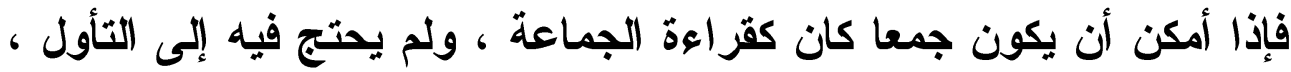

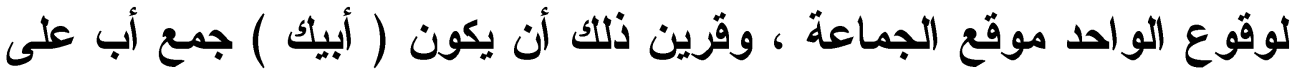

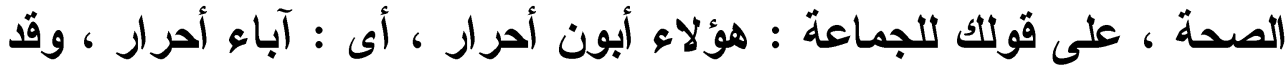

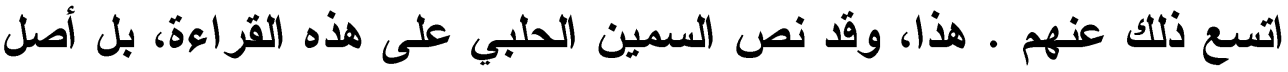

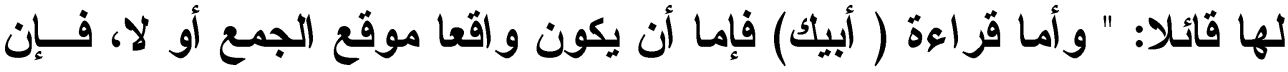

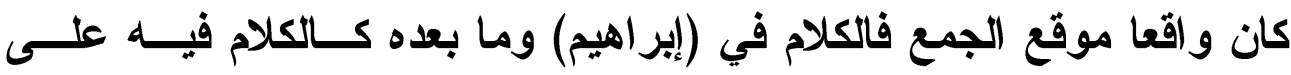

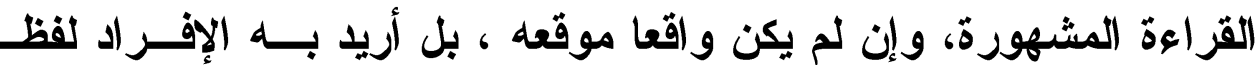

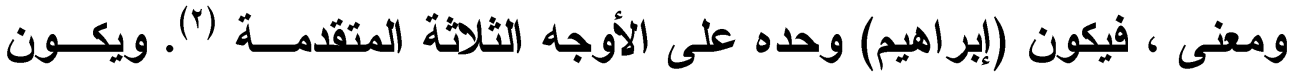
إسماعيل وما بعده عطفا على ( أبيك) ، أي: و إله إسماعيل. الثاني: يكون جمع سلامة بالياء و النون، و إنما حذفت النون للإضافة،

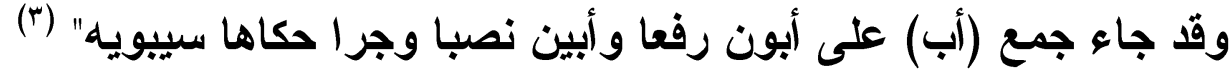

1 - المحتسب : 19 / 1 ـولم أقف على هذه القراعة في كتاب السبعة. r- و المقصود بالأوجه الثلاثة : البلال ، وعطف البيان، و النصب بإضمار أعني. انظـر : الـــر

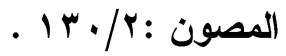

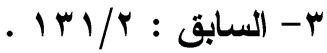

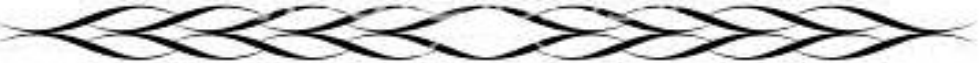




\section{الترقيم الدوله ISSN 2356-9050}

(1) 1179
حولية كلية اللفة العربية بجرجا مجية مجلة علمية محكمة المية

ومن أبيات الكتاب :

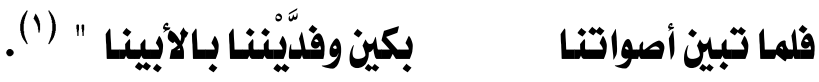

وهنا وقع الخلاف حول كلمة ( أبيك ) فقد أقرها ابن مجاهد بالتوحيد ،

غير أن هذا الإقرار من ابن مجاهد لم يحظ بالقبول عند ابن جنى ، لماذا؟ لأن أكثر القراعة : ( وإله آبائك ) بالجمع .

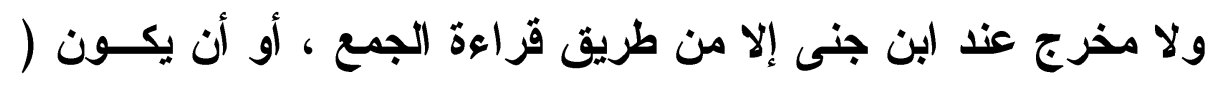

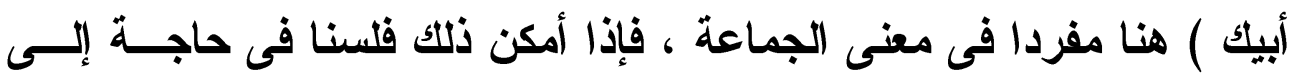

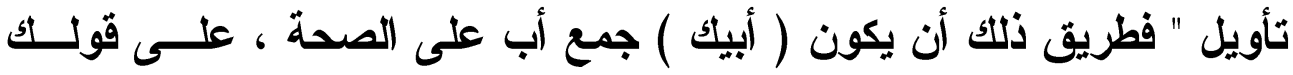

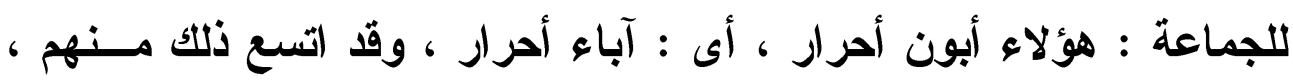

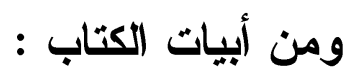

بكين وفليننا بـالأبينا (r) فلما تبين أصواتنا هذا ، وقا عمد النحاس إلى شيء من التفنيد ، خلاصـــه أن قـراءة

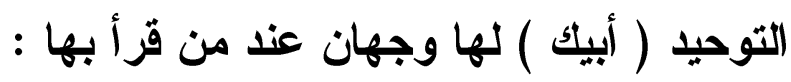

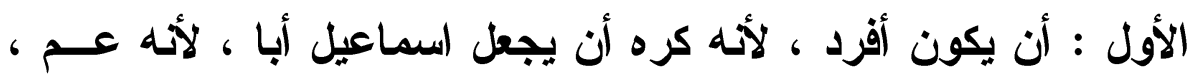
وقد رد أبو جعفر هذا التأويل

1 - المحتسب : 199/1 .

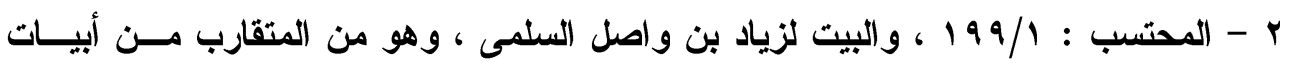

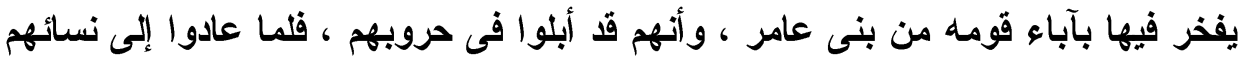

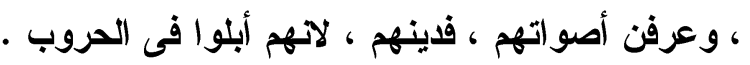


" لأن العرب تسمى العم أبا ، وأيضا فإن هذا بعيد ، لأنه يقدر : وإلــهـ

إسماعيل ، و إله اسحاق ، فيخرج هو وأبوه الأدنى من نسب إبراهيم ، ففـى هذا من البعد ما لا خفاء فيه " (').

والثانى : إنما هو مذهب سيبويه ، الأى سبقت الإثارة إليه ، قال : "

وفيه وجه آخر على مذهب سيبويه ، يكون ( أبيك ) جمعا ، حكى سيبويه :

أبون وأبين " (r)

وقد أكد ابن جنى مذهبه بقوله : " ويؤكد أن المراد به الجماعة ما جاء

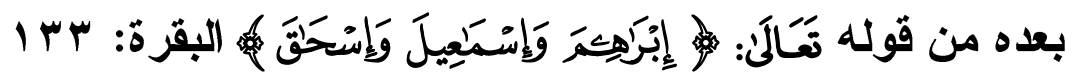

فأبدل الجماعة من أبيك ، فهو جماعة لا محالة ، لاستحالة إبدال الأكثر من الأقل فيصير قوله - تعالى : ( وإله أبيك ) كقوله : ( وإله ذويك ) هـــا هو الوجه وعليه فليكن العمل " (").

وجمع الباب أثنار إليه ابن منظور فى اللسان(؛) ، ولما أجاز المبرد ابى وأخى وحمى ، وذلك إذا أضيفت الكلمة إلى ياء المتكلم ، محتجا بقــول الشاعر ، وهو من الكامل :

وأبى مالك ذو المجازبلدار (•) - (ن) قدر أحلك ذا المجازوقدل أرى

$$
\begin{aligned}
& 1 \text { - إعراب القرآن : } \\
& \text { r } \\
& \text { r - المحتسب : / / / . r . . } \\
& \text { ع - لسان العرب : أبا . }
\end{aligned}
$$

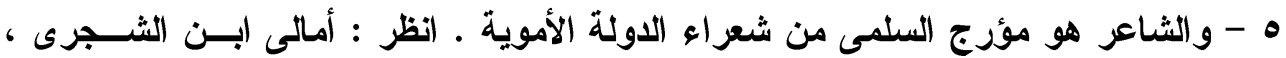

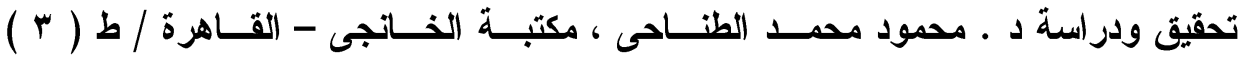

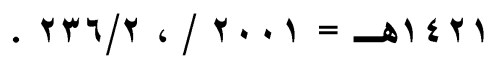




\section{الترقيم الدولخ}

ISSN 2356-9050

لما أجاز المبرد ذلك ، منع منه أبو على ، وقال : " إن أبى فى البيـــ جمع ( أب ) على لغة من قال فى جمعه ( أبون وأبين ) واحـتـج بالشــاهد الأى سبق أن احتج به ابن جنى (1). وكأن هذين الجمعين لا خلاف عليهما فى الأوساط اللغوية .

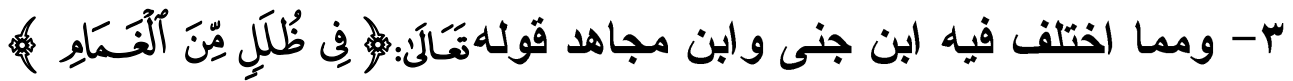

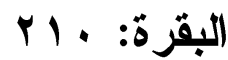

وبالتحديد وقع الخلاف حول قراعة قتادة ( فى ظلال من الغمام ) فقــــ ذهب ابن مجاهد إلى أن (ظلال ) جمع ( ظل ) فى حين ذهب ابن جنى إلـى أن ( ظلل ) جمع ( ظلة ) ، كخلة وخلا ، وقلة وقلل (r). ويمكن - بعد الاستعانة بمعطيات المعاجم ، على اختلافها - حسم هذا

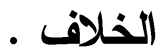

قال الر اغب: "و الظلل جمع ظلة، كغرفة وغرف، وقربة، وقرب " (). كذلك ، وقد أثنار الر اغب إلى القراعة الثانية ، قال : " وقريء : فـى ظلل ، وذلك إما جمع (ظلة) نحو : غلبة وغلاب ، وحفرة وحفار (؛)، وإمــا

- و هو شاهد زياد السلمى ، المشار إليه سابقا .

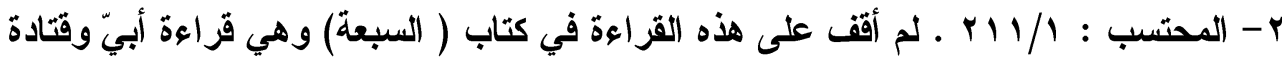

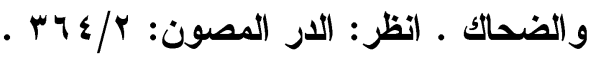
r- المفردات فى غريب القرآن : الر اغب الأصفهاتى ، المطبعة الميمنية بمصـر ، ص • rV ،

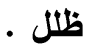
ع - السابق • وقد أثشار السمين الحلبي إلى هذه القراءة، ونص على أن (ظلال) جمع ( ظلة) .

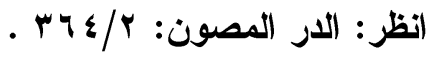


مناقشة ابن جني (بrarهـ

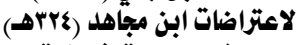

على بعض الروايات في الماحتسب مئ

جمع ظل " (1) ولعلك تلمح قدرا من الخلط فى طرح الجمـوع و المفـردات ،

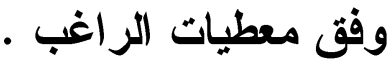

وقال فى القاموس : " الظل - بالكسر - نقيض الضح ، والجمع ظلال وظلول وأظلال "(†)، وهو ما ذهب إليه الزاغب ، وهو مذهب يستقيم مع قول

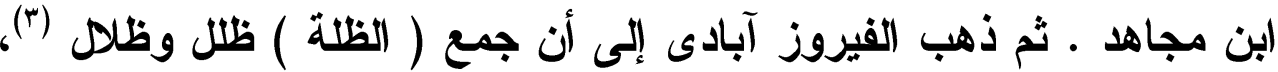
وهذا يستقيم وقول ابن جنى كما سبقت الإثارة إليه .

بل نص صاحب اللسان على ما ذهب إليه (بن مجاهد فقال : " وجمــع الظل : أظلال وظلال وظلول"(). بل تابعه على ذلك أيضا الزبيدى ، فالظـلـل

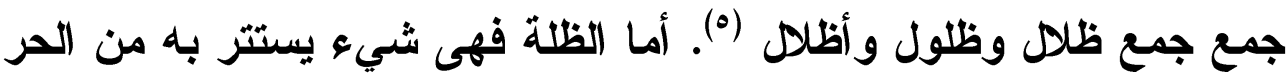

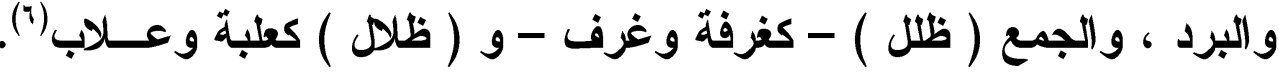
وهكنا جاء الجمع ( ظــل ) قاســما مشــركا بـين المفـردين ( ظــل ) و ( ظلة ) وذلك فى بعض الاحيان .

ولو تركنا معاجم اللغة إلى كتاب ( إعراب القــرآن ) لوجــناه يقـر

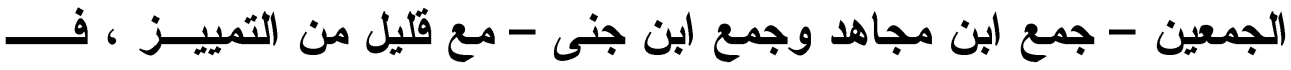
( ظلل ) جمع ظلة فى التكسير ، و ( ظلال ) جمع (ظل) فى الكثير ، وقيـل فل فيل

1 - - وهذا السوق يوافق قول ابن جنى .

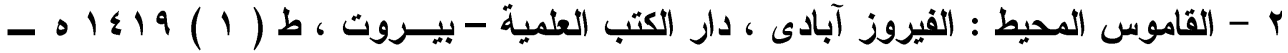
.

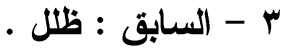

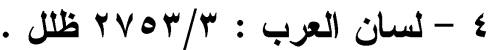

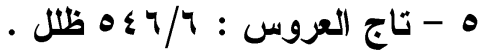
1 


\section{الترقيم الدوله}

ISSN 2356-9050

ظلل جمع ظلة ، مثل قلة وقلال ('). فجمع النحاس بين مر ادى ابن مجاهـــ وابن جنى ، وإن كان الأثهر أن ( ظلال ) جمع ( ظل ) لكثرة المذاهب التى ترجح توجيه دفة الجمع (ظلهل ) نحو المفرد ( ظل ) . ع - ومن اعتر اضات ابن مجاهد على ابـن جنــى رده لقــراءة أبـى

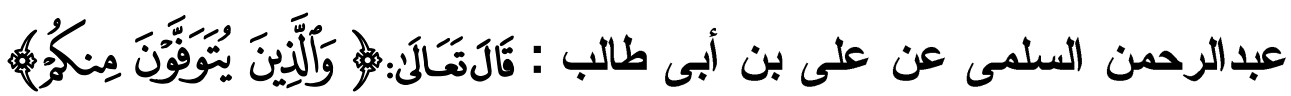
البقرة: ع عr ـ بقتح الياء .

\section{قال (بن مجاهد : " ولا يقرأ بها " (r)}

قال ابن جنى : " هذا الأى أنكره ابن مجاهد عندى مســتقيم جـائز ، وذلك أنه على حذف المفعول، أى : والأين يتوفون ايامهم أو أعمـارهم أو مائ

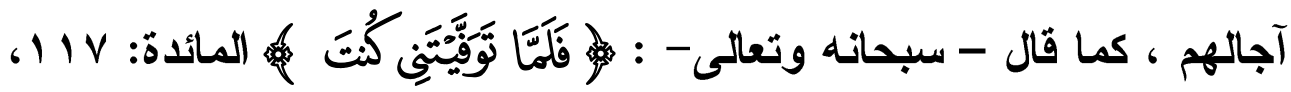

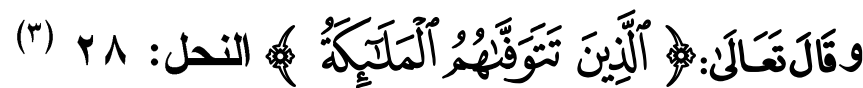
فالخلاف هنا حول قراعة على - رضى الله عنه - : ( والأين يتوفون

منكم ) بفتح الياء، فقد اعترض عليها (بن مجاهد، فقال: " لا يقرأ بها "(؛). وأنا لا أدرى ما القصد من وراء عبارة ابن مجاهد : " لا يقرأ بها " ؟

1 - إعراب القرآن : للنحاس ، تحقيق : دـ ـ زهير غازى زاهد ، عالم الكتب - القــاهرة ، ط

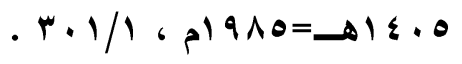
r - المحتسب : 10/1 / . ولم أجد هذا النص في كتاب السبعة. • 
ألكونها غير متواترة ، فلا تجوز الصــلاة بهـــا ، ولا يجــوز التعبـــ بتلاوتها ؟ أم لكونها شاذة على المستوى اللغوى ؟ وإن كان الظاهر من رد ابن جنى أن ابن مجاهد يستنكرها على المستوى اللغوى .

بل وإن ابن جنى لم يقف بهذا المفهوم عند حد المحتسب وحسب ، بل رصدها فى كتابه (الخصائص) ممثلا بها - وينظائرها من القرآن والشعر لحذف المفعول ، قال فى الخصائص : " وقد حذف المفعول به ، نحو قوله ـ

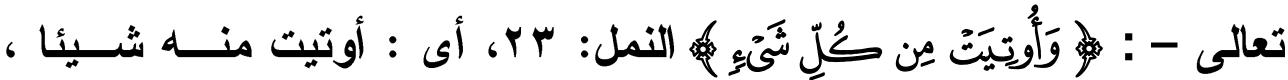

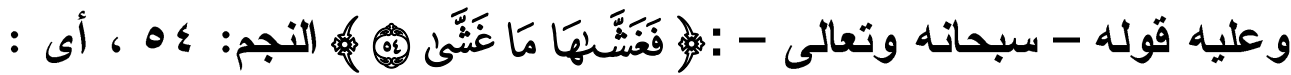
غشاها إياها ، فحذف المفعولين جميعا " (1). ثتم احتج بشاهد الحطيئة : كصونك من رداء شرعبى منعمة تصوز إليك منها

أى : تصون الكلام منها ، وهو كثير جدا (ז). وقد رد ابن جنى اعتراض ابن مجاهد بقوله : " هذا الأى أنكره ابـن مجاهد عندى مستقيم جائز ، وذلك أنه على حذف المفعول " (").

1 - الخصائص : ابن جنى ، تحقيق : د ـ عبدالمجيد هنداوى ، دار الكتب العلمية - بيروت ،

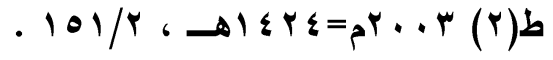

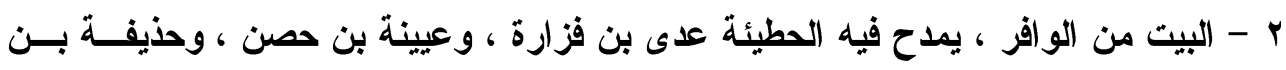
بلر ـ أراد أنها فى خصب ونعمة ، وقوله ( تصون إليك ) أى : تحفظ عندك سرها وحديثها ، لا تبوح به ، كما تصون رداء شرعبيا ، والثرعبية : برود فيها خطوط طوال ـ المحتسب

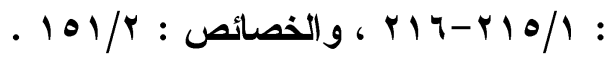

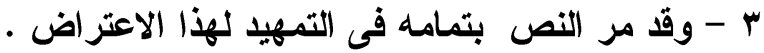




\section{الترقيم الدولي}

ISSN 2356-9050

وما ذكره (بن جنى فى المحتسب ، ذكره الزمخثرى فى الكثــاف (')، وذكره أبو حيان فى البحر المحيط ، قال : " وقرأ الجمهور ( يتوفون ) بضم الياء ، مبنيا للمفعول ، وقرأ على والمفضل عن عاصم ، بفتح الياء، مبنيــا للفاعل ، ومعنى هذه القراعة أنهم يستوفون أجالهم " (r).

بل ورد ذكره فى هامش البحر المحيط : " وقرى ( يتوفـون ) مبنيــائ

للفاعل ، ومبنيا للمفعول ، أى : يتوفاهم الله ، أو : يستوفون آجالهم " (). ولو تركنا كتب التفسير إلى أحد مصنفات النحاة ، وهو شرح المفصل لابن يعيش ، لوجدناه يؤصل لحذف المفعول ، إذ يقول : " اعلم أن المفعول لما كان فضلة ، تستقل الجملة دونه ، وينعقد الكلام من الفعل والفاعل بـلا مفعول جاز حذفه وسقوطه وإن كان الفعل يقتضيه " (ء). وأضاف ابن عقيل أنه يجوز حذف الفضلة ، وهى ما يمكن الاســتغاء عنه كالمفعول به ، إن لم يضر ، وعلى نحو ما ورد فى قوله - تعسالى - :

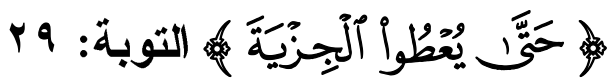

$$
\begin{aligned}
& 1 \text { - الكشاف : PVT/I } \\
& \text { r - البحر المحيط : r r r r . . }
\end{aligned}
$$

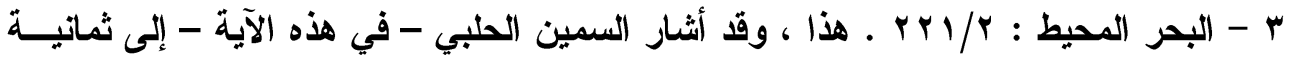

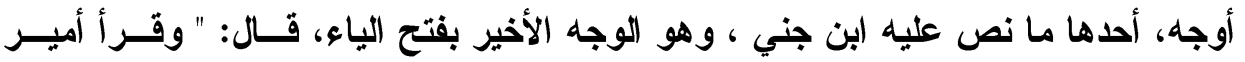

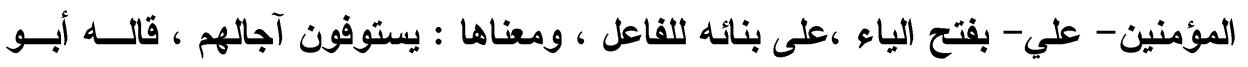

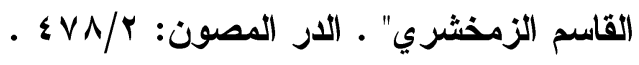

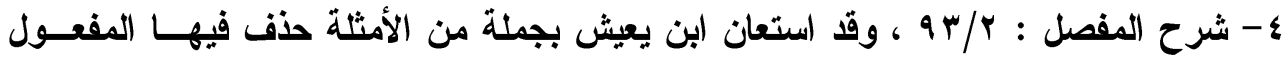

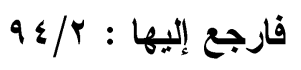




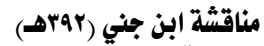

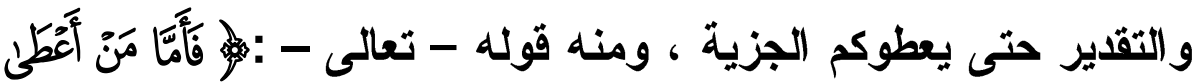

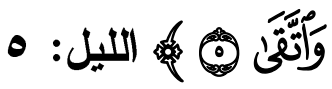

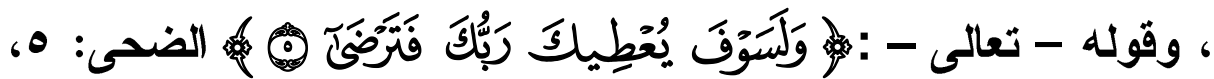

فإن ضر حذف الفضلة لم يجز حذفها(1).

والآية - موضع البحث - لا يضر حذف المفعول فيها ، وقد قــره -

بغير عناء - كل من تعرض لتأويل هذه الآية من المفسرين والنحــاة ، بــل

ربما كان تقدير المفعول فيها أيسر من تقديره فى غيرها مــــا أثــار إليــهـ

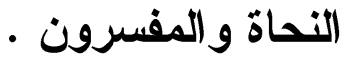

ه- ومن الآيات التى وقع حول إحدى رواياتها الاعتراض اللاحـق ،

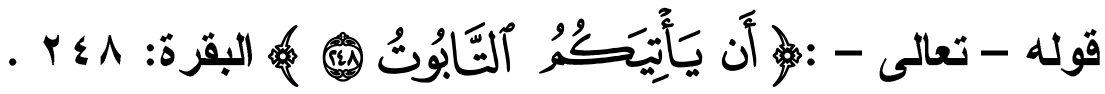

قال ابن مجاهد : ( التابوث ) بالتاء ، قراعة النــاس جميعــا ، ولغــة

كلأنصار ( التابوه) بالهاء"(ז).

قال أبو الفتح :" أما ظاهر الأمر فأن يكون هذا الحرفان من أصــلين: أحدهما ( ت ب ت ) والآخر ( ت ب هـ ) ثم من بعد هذا فالقول أن الهــاء

فى التابوه بدل من التاء فى التابوت " (r).

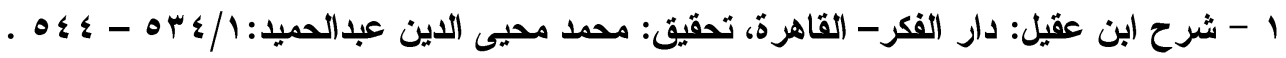

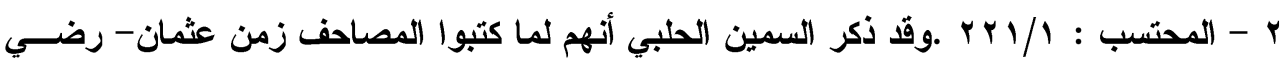

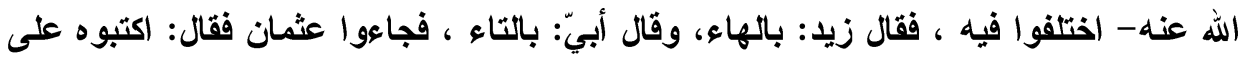

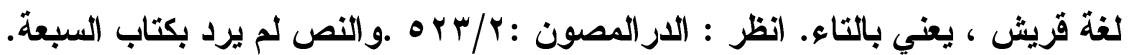

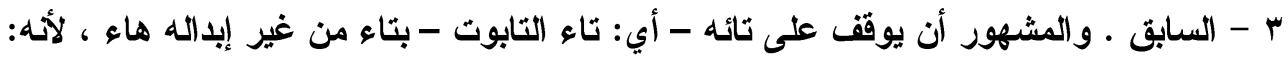

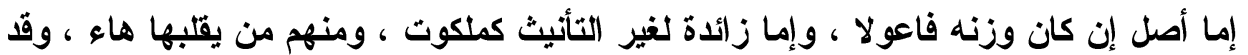

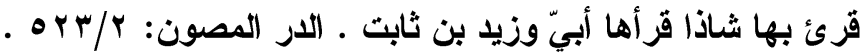

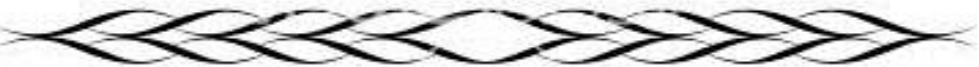




\section{الترقيم الدوله \\ ISSN 2356-9050}

فابن مجاهد يقر لفظة ( التابوت ) جنبا إلى جنب مع كلمة ( التـابوه )

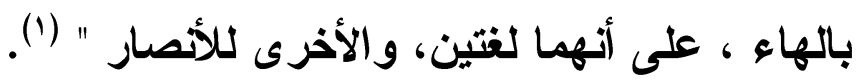

أما ابن جنى فير اهما راجعين إلى أصلين مختلفين ، فالأولى ( التابوت) من ( تبت ) و الثانية (التابوه) من ( تبه ) ثم بعد ذلك يقع الإبــال ، إبـــال الهاء فى التابوه من التاء فى التابوت

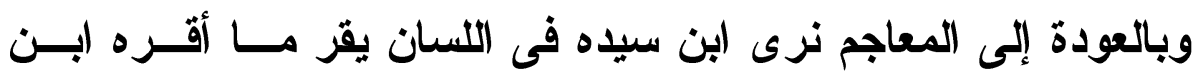

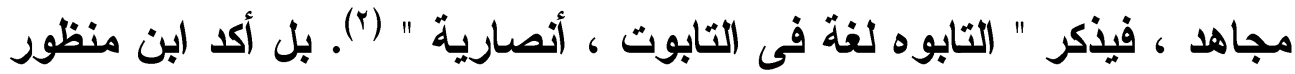

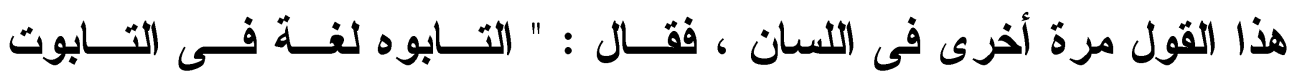

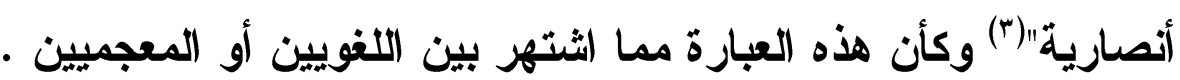
أما الزبيدى ، فقد أدرج لغة ثالثة ، وهى : " التََّّوت - كصبور - لغة

فى (التابوت " (£)

ثم ذكر كلاما لابن منظور خلاصته أن الثيخ أبا محمد بن برى قد أنكر

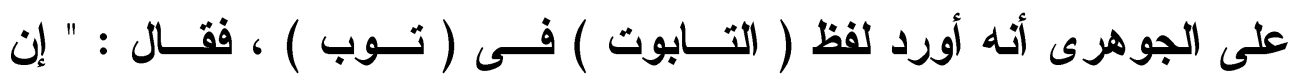
الجوهرى أساء تصريفه حتى رده إلى تابوت .

قال: وكان الصواب أن يذكره فى فصل ( تبت )، لأن تــاءه أصـلية ،

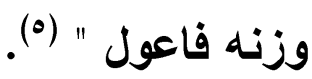

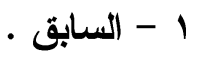
r - لسان العرب : 10/1 1 تع تبت .

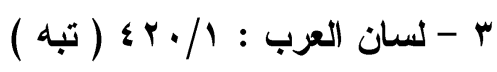

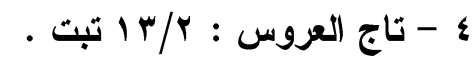

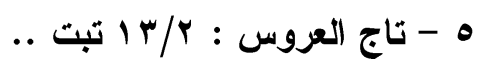


إذن فابن مجاهد قضى بما اتتهى إليه أمر اللفظين ، فالتابوه لغة فـى التابوت ، بإبدال التاءع هاء، أما ابن جنى فقد أكـــد أولا علــى أن اللفظـين راجعان إلى أصلين مختلفين ( تبث ) و ( تبه ) ثم بعد ذلك وقع الإبدال . والبلال : " أن تقيم حرفا مكان حرف ، إما ضرورة ، وإمسـا صــعة ،

و إما استحسانا " (1)

\section{وهو على ضربين : و}

أحلدهما : إقامةة حرف مكان حرف غيره ، نحو تاء تُخَمَة وتُكَأَة .

والثانى : قلب الحرف نفسه إلى لفظ غيره ، على معنى إحالته غليه ،

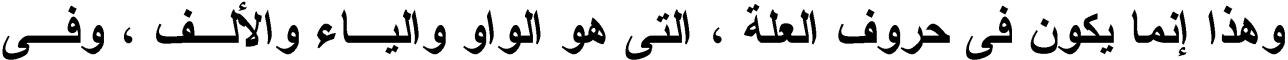
الهمزة أيضا لمقاربتها إياها وكثرة تغيرها (؟) وقد أصل ابن جنى لإبدال التاء هاء ، فكلاهما حرف مهموس (ז)، ومن حروف الزيادة فى غير هذا الموضع . و أيضا فقد أبدلوا الهاء من التاء التّى للتأتيث فى الوقف ، فقــالوا :

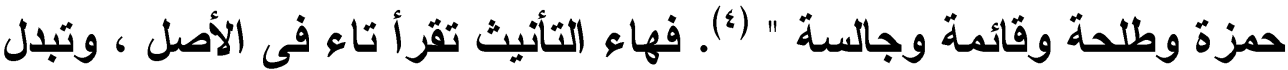
وتبدل هاء عند الوقف ، ويوقف عليها بالسكون المحض ، مثــل : رحمـــة

$$
\begin{aligned}
& 1 \text { - شرح المفصل : • 10/1 . } \\
& \text { r }
\end{aligned}
$$

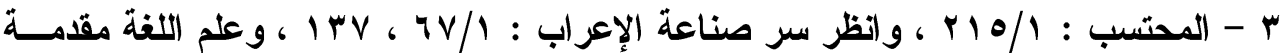

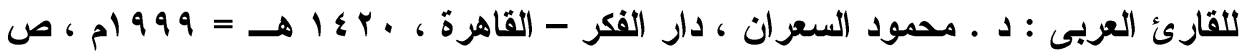

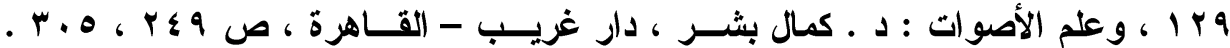

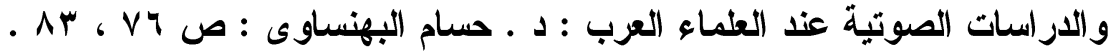

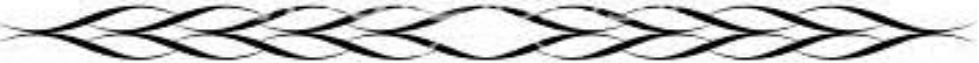




\section{الترقير الدولخ}

ISSN 2356-9050
की $11 \times 7$
حولية كلية اللفة العربية بجرجا مجية مجلة علمية محكمة

ونعمة (')، فضلا عن " أن عامة عقيل فيما لا نز ال نتلقاه من أفواهها ، تقول فى الفرات : الفر اه ، باللهاء فى الوصل والوقف " (r). צ- ومن جملة اعتر اضات ابن مجاهد على ابن جنى ، اعتر اضه حول

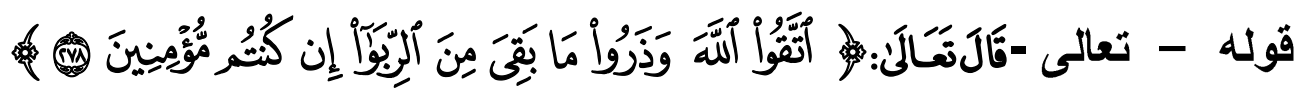

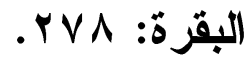

فقد قر أها الحسن : ( اتقوا الله وذروا ما بِّى من الربا ) بكسر القاف ، وسكون الياء .

وروى ابن مجاهد عن أبى زيد بن أبى السمال : أنه كان يقرأ : ( مـــا

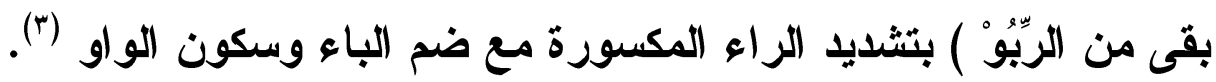
قال ابن جنى : " فى هذا الحرف ضربان من الشذوذ : أحدهما : الخروج من الكسر إلى الضم بناء لازما . والآخر : وقوع الواو بعد الضمة فى آخر الاسم ، وهذا شيء لم يــأت إلا الفعل ، نحو : يغزو ويدعو ويخلو ، وأما ( ذو ) الطائية التـى بمعنـى التى

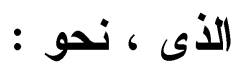
لأتتحيين للعظم ذو أنا عارقه

1 - انظر : باية المريد فى فن التجويد : سيد مختار أبو شادى ، دار أعلام السلف - القاهرة

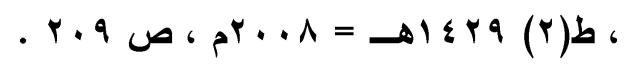
r

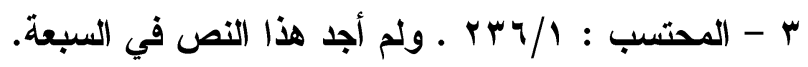


فشاذ ، وعلى أن منهم من يغير هذه الواو إذا فارق الرفع ، فيقــول :

$$
\text { رأيث ذا قام أخوه ، ومررث بذى قام أخوه " ('). }
$$

فهنا وقع الخلاف حول ما رواه ابن مجاهد عن أبع زيـــ عـن أبــى السمال ، أنه كان يقرأ : ( ما بقى من الريو ) مضــمومة البــاء ، ســاكنة الواو، وفيه شذوذ من وجهين : أحدهما : الخروج من الكسر إلى الضم بناء لازما . والآخر : وقوع الواو بعد الضمة في آخر الاسم (r)، وقد جاء اعتر اض ابن جنى هنا ممثلا فى أن وقوع الواو بعد الضمة لم يأت إلا فى الفعل ، نحو

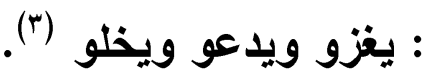

وردا على سؤال قد يثور فى خلا المتلقى بوقـوع هــذا فــى ( ذو ) الطائية ، التى بمعنى الذى ، نحو : لأتتحين للعظم ذو أنا عارقه (ع). فأجاب ابن جنى بأن هذا شاذ ، فضلا عن ورود هذه الكلمة بالأف فى حالة النصب ، نحو : رأيت ذا قام أخوه ، وورودها بالياء فى حالة الجـر ،

$$
\begin{aligned}
& 1 \text { - السابق : 1/1 } \\
& \text { r } \\
& \text { r - السابق - العابق }
\end{aligned}
$$

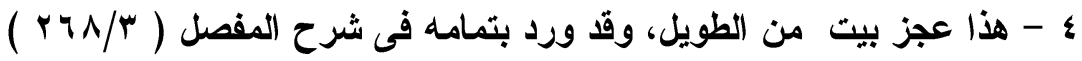
لكئز له تفيره بعض ما قد صنعتم ل الأتحين للعظم ذو أنا عارقهل

ـ و البيت لعارق الطائى ، واسمه قيس بن جروة الطائي ، و انتحاه فصده ، وذو بمعنى الأى فى في

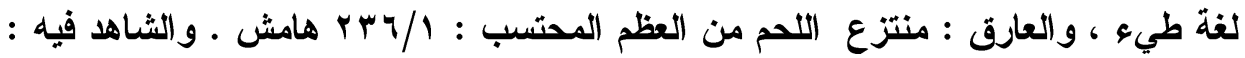

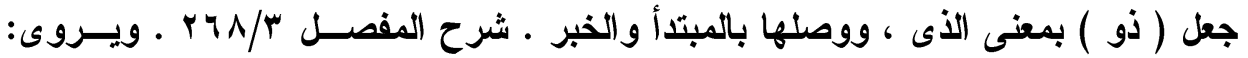
لأنتحين للعظم ذو أنا عارقه . 


\section{الترقير الدولخ \\ ISSN 2356-9050}

نحو : مررت بذى قام أخوه (1). وهذا عين ما نص عليه (بن يعيش ، قال : " وأما ( ذو ) فإن طيئا تقول : هذا ذو وقال ذالك ، يريدون الأى قـال ذالك ، وهى ( ذو ) بمعنى صاحب ، نقلوها إلى معنى الذى ، ووصلوها بالجملة من الفعل والفاعل والمبتدأ والخبر ، الأى توصل بها الأى ، وبنوها لاحتياحهــا إلى ما بعدها ، كما كانت الأى مبنية ، فقالوا : هذا زيد ذو قام ، ورأيت زيدا ذو قام ، ومررث بزيد ذو قام ، فيكون فى حالة الرفع والنصب والجر بالواو ، وهذه الواو عين الكلمة ، وليست علمة الرفع • وتقول : مررث بالمرأة ذو قامت ، وبالرجلين ذو قاما وبالرجال ذو قاموا ، يستوى فيه التثنية والجمع و المؤنث " (r) (ب)

وكما نص ابن جنى على " أن منهم من يغير هـــه الــواو إذا فــارق الرفع، فيقول : رأيت ذو قام أخوه "() فقد نص كذلك ابن يعيش علــى " أن

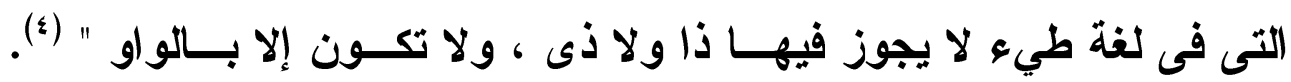
وأضاف المحقق ، قائلا : " بعض الطائيين أعربها " (ه). كما علل ابن جنى ما وقع فى ( الريو ) أنهم فخموا الألف انتحاء بـهـا

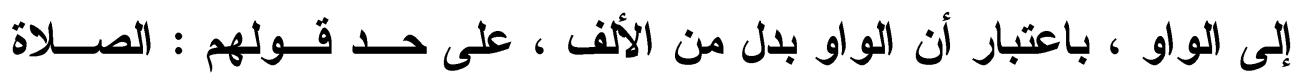
و الزكاة ومشكاة ، وكأنه بين التفخيم فقوى الصوت ، فكان الواو أو كاد .

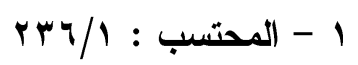

r - شرح المفصل : ابن يعيش : TTV/T ، ب بتصرف يسير .

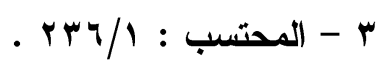

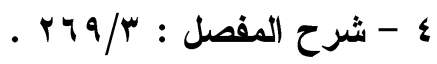
ه - السابق ، هامش 
أما الشذوذ الأول وهو الخروج من الكسر إلى الضم بناء لازما (1)، فقد

وقف أبو حيان عند هذه العبارة مفسرا ومعقبا ، يقول : " ويعنــى بقولـــهـ : (بناء لازما) أنه قـ يكون فى ذللك عارضا ، نحو ( الحبك ) فكسـرة البــاء ليست لازمة ، ومن قولهم ( الردّدو ) فى الوقف فضمة الدال ليست لازمة"(؟). غير أن أبا حيان قد اعترض على عبارة ابن جنى : " وهذا شيء لــم

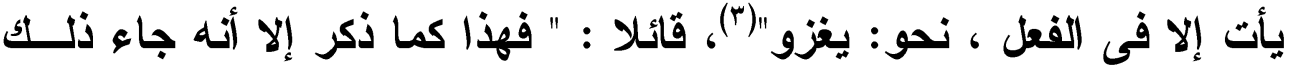
فى الأسماء الستة فى حالة الرفع ، فله أن يقول: " لما لم يكن ذلك لازما فى النصب والجر ، لم يكن ناقصا لما ذكروا " وأضاف أبو حيان : " إن الضــمة التى فيما قبل الآخر إنما هى للاتباع ، فليست ضمة تكون فى أصـلـل بنيــة

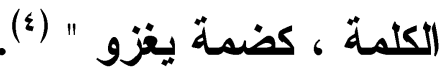
وعلى المستوى الصوتى ، فإن جهاز الصوت قد يجد مشقة فى الاتثال من الكسر إلى الصم ، لأن نطق الكسرة يقتضى تصعيد مقدمة اللسان نحسـو وسط الحنك الأعلى ، بحيث يكون الفراغ بينهما كافيا لمرور الهــواء ، دون أن يحدث فى مروره بهذا الموضع أى نحو من الاحتكائ والحفيف ، وجعلت الأوتار الصوتية تهتز مع ذلك ، عندئذ يتتج صوت الكسرة الخالصة " (•). أما صوت الضمة فإن يقتضى ارتفاع أقصى اللسان نحو سقف الحنـــ - لا مقدمته - كما فى حالة الكسرة - بحيث لا يحدث للهواء المــار بهــــه

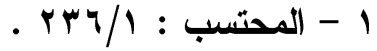

$$
\begin{aligned}
& \text { r -البحر المحيط : r r r r r . } \\
& \text { r - المحتسب : البحس / } \\
& \text { ع - البحر المحيط : r r }
\end{aligned}
$$

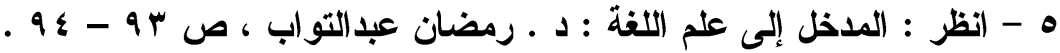




\section{الترقيم الدولم \\ ISSN 2356-9050}

المنطقة أى نوع من الحفيف ، مع حدوث ذبذبة فى الأوتار الصوتية ، عندئذ

ينتج عن ذلك صوث الضمة الخالصة (1).

وعليه ، فقد رجحت المتابعة رأى ابن جنى مقارنة بما ذهب إليه ابـن

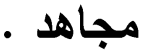

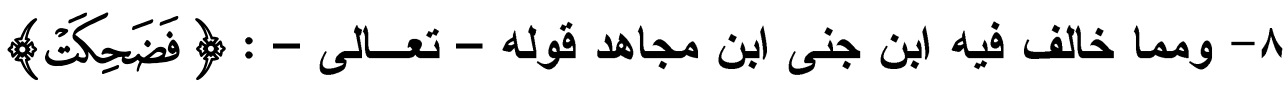

هود:

فقد رواها محمد بن زياد الأعر ابح ( فَضَحَكَتْ ) بفتح الحاء ، خلافَا لما ير اه (بن جنى ، كما خالف ابن مجاهد فى تفسير الضحك بالحيض (r)، وكان ابن مجاهد قد اعتمد هذا التأويل استنادا إلى جملة من الثواهد : منها شاهد أبى ذؤيب الهزلى ، وهو من المنقارب : مثل دم الجوف يوم اللقا ضحك الأرانب فوق الصفا

يعنى الحيض ، فيما زعم بعضهم (r). ومنها شاهد تأبط شرا :

تضحك الضبع لقتلى هذيل (๕).

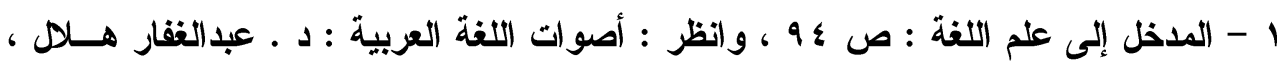

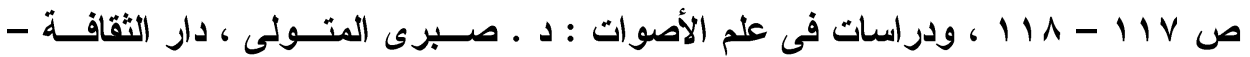

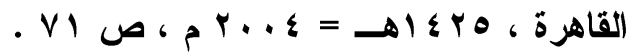

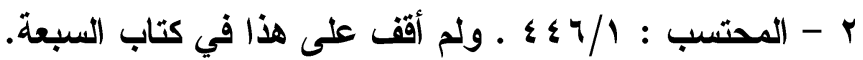

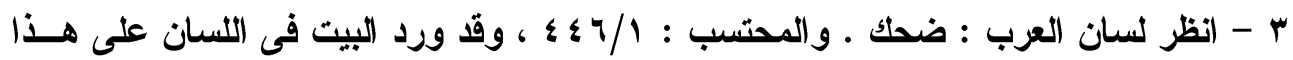
مثل دم الجوف يوم اللقا

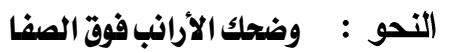

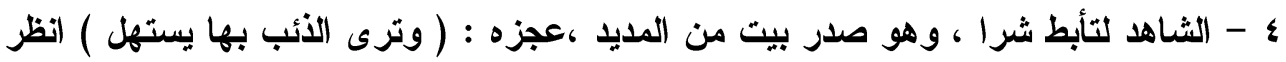

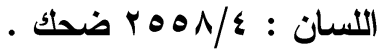


أى : إن الضبع إذا أكلت لحوم الناس أو شربت دماءهم طمثت ، وقــــ

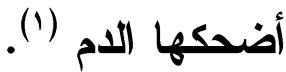

وقد رد ابن جنى قراعة ابن الاعرابى ، بفتح الحاء ، قائلا : " فــيس

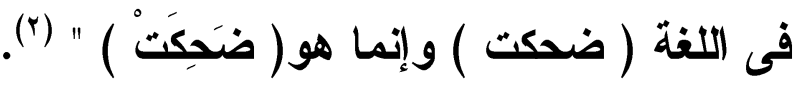

كما رد تأويل ابن مجاهد للضحك بالحيض من وجهين:الاول: قوله:" ومن

أين لهم أن الضبع تحيض؟ وقال: يا بنى إنما تكثر للقتلى إذا رأتهم "(").

كما ساق تأويلا آخر لشاهد تأبط شرا ، يقصى به تأويل ابن مجاهـــ ،

قال : " أى تستبشر لقتلاهم لتأكلهم ، فيهر بعضهم على بعض فجعله ضحكا

وبالعودة إلى معاجم اللغة وكتب المفردات تبين لى صحة ما ذهب إليه ابن جنى ، وعلى النحو الأى طرحته المصادر سالفة الأكر .

ففى مفردات الر اغب : صحك يضحك ضحكا ، بكسر الحاء فى الماضى

والمصدر (•).

وكذلك الحال فى التهاية ، يقول ابن الأثنــر : " وكةــولهم : ضــــ

الأرض ، إذا أخرجت نباتها وزهرتها " (").

1 - لسان العرب : \&/4 r ضحك .

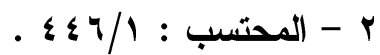

r - لسان العرب : V/ ع § ضحك .

؛ - السابق •

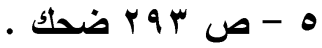

. $V T / \mu-T$

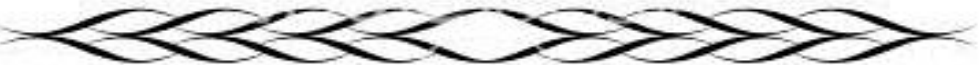




\section{الترقير الدولخ}

ISSN 2356-9050

وهو نفس الطرح الأى ورد فى ســائر المعــاجم ، فقـى الصــحاح

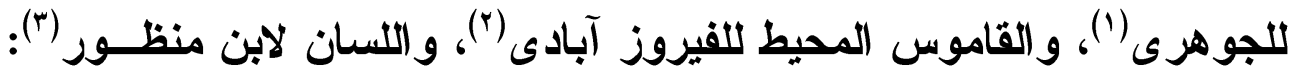
ضحك بكسر الحاء.

فكل المعاجم - على اختلافها - ترجح ، بل تجزم بصحة ما قاله ابـن جنى ، بل أورد ابن منظور هذا الفعل فى مواطن عدة من معجمــه ، وردت

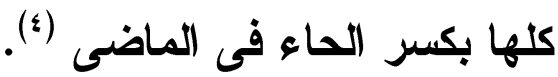

وبمثل ما رد به ابن جنى هذا المفهوم رده ابن دريد أيضا ، قــال : لأبى حاتم الطائى فى مناسبة هذا البيت - : " ومن أيـن لهـــم أن الضــبع تحيض ، وقال يا بنى : إنما تكشر للقتلى إذا رأتهم"(ه). وقال فى اللسان : " وكان ابن دريد يرد هذا ، ويقــول : مــن شـــاهد الضباع عند حيضها ، فيعلم أنها تحيض ؟ وإنما أر اد الشاعر أنها تكشر لأكل اللحوم ، وهذا سهو منه ، فجعل كشرها ضحكا ، وقيـل : أنهـــا تشتبثــر بالقتلى إذا (كتتهم ، فيهر بعضها على بعض ، فجعل هريزها ضحكا " (†). وقبل الإجابة على السؤال المطروح : فما سر ضحكها إذن ؟ أقول : لـ أر فيما وقعت عليه ياى من المصادر من يوثث هذا الرأى من اللغويين ، بل

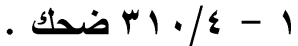
. .

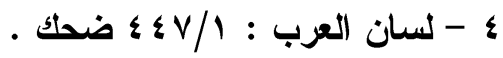
ه - المحتسب : V/

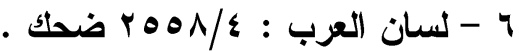


نقل ابن منظور كلامالابن عباس يللى فيه بلدلوه حول مدلول هذه الكلمــة ،

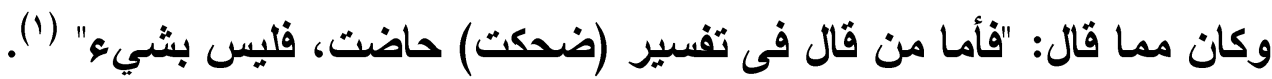
ومن قبله الر اغب فى المفردات : " وقول من قال حاضت فليس ذلـــــ تفسير القوله (فضحكت) كما تصوره بعض المفسـرين ، فقــال : ضـــكت

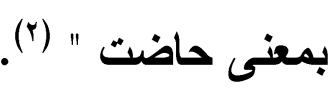

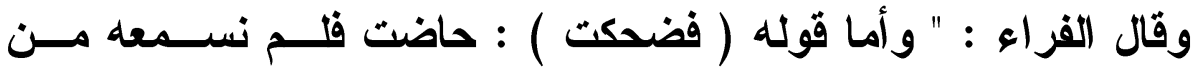

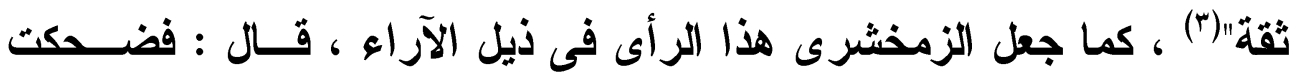

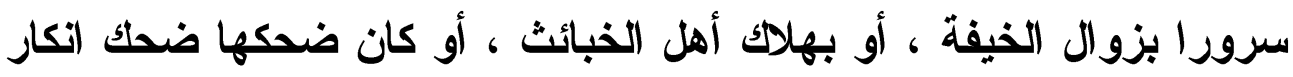
لفعتهم ، وقد أظلهم العذاب ، ... ، ... ، وقيل : فضحكت : حاضت " (؛).

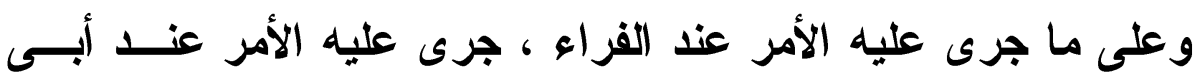
حيان ، فقد حمل اللفظة - الضحك - على الضحك المعروف ، الذى يعبر به

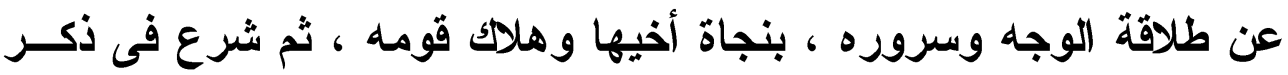

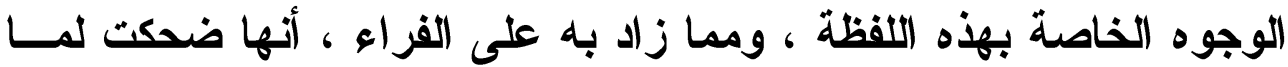

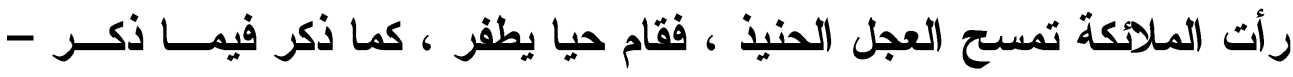

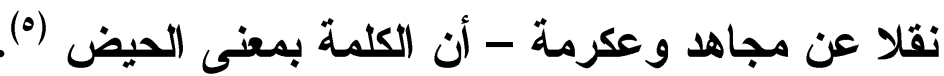

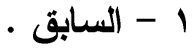
r - المفردات فى غريب القرآن : ص ع و ج ، كما لم يشر إليه ابن الأثير فى النهاية انظـــ

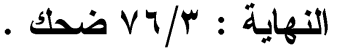

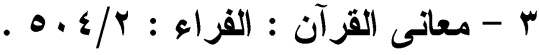

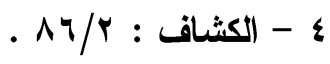

$$
\begin{aligned}
& \text { 0 - انظر : البحر المحيط : }
\end{aligned}
$$

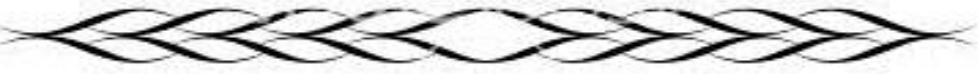




\section{الترقير الدولخ \\ ISSN 2356-9050}

والراجح عندى أنها ضحكت تعجبا من البشارة ، بلالاكة قوله - تعسالى - -

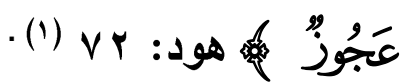

9- ومما تفاوت فيه الرأيان تفاوتا لا يرتقى إلى درجة الخلاف ما أثير

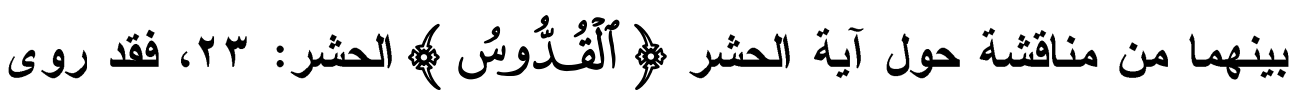
ابن مجاهد وأبو حاتم عن يعقوب ، قال : سمعت أعز ابيا يكنى أبا الدينار عند

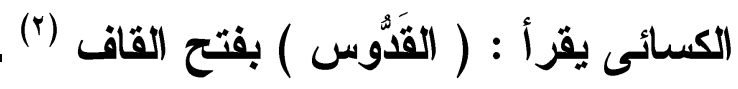
وأجاب ابن جنى قائحلا : " فَعْول فى الصفة قليل ، وذكر ســيبويه فـى

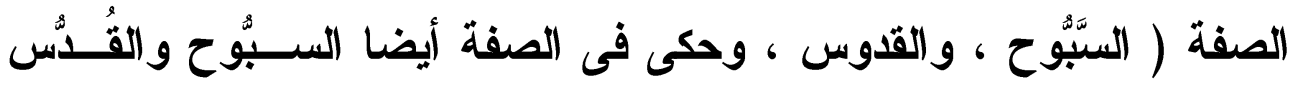
بالضم ، وإثبات الفَعُول الاسم ، كشبوط وسمور وتنور وسـفود وهبـود -

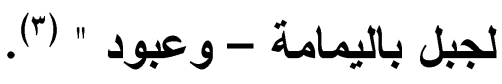
وبإمعان النظر فيما ساقه ابن مجاهد ومن بعده ابن جنى ، فإن ما قاله

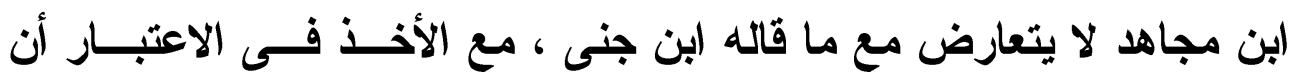

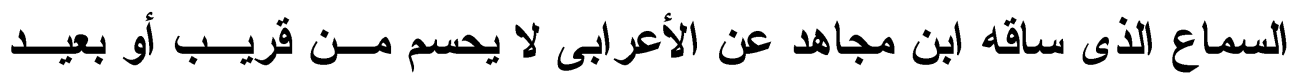
موقفه من هذا البناء ، إلا الإقرار الأى يسلم من سوقه لقــول الأعرابــى ، وربما كان إقراره من باب أنه يدلل بهذه الحالة على إمكانيــة ورود البنــاء

1 - انظر المفردات في غريب القرآن : ص ع ه ب ضحك .

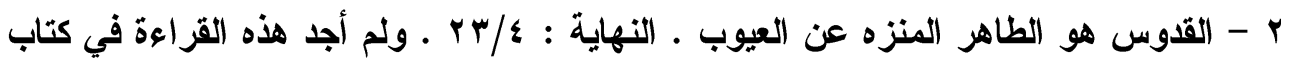
(السبعة.

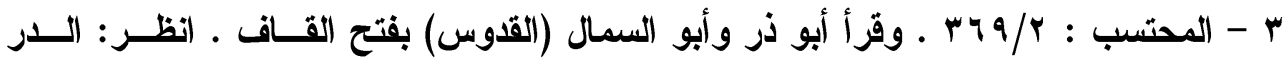

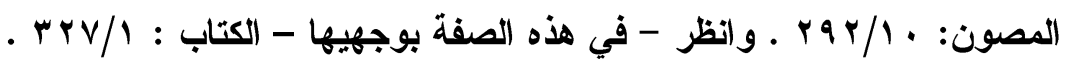


بالقتح ، الأمر الذى يعكس أن ضم القاف فى ( القدوس ) إنما هو الأصـل ، لا سيما وقد ذهب جملة من النحاة والمفسرين وعلماء القراءات والمعجميين

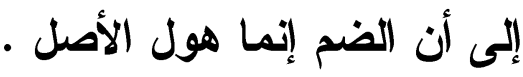

قال الزمخشرى : " القدوس : بالضم والفتح " (1).

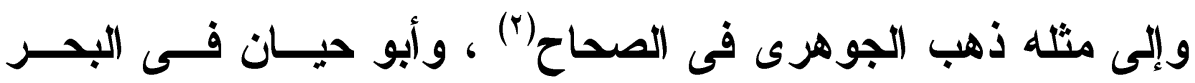

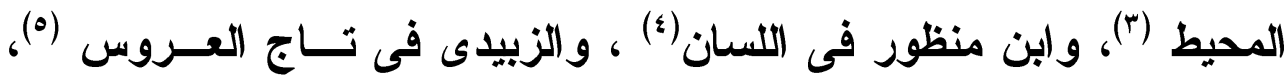
وابن الأثير فى النهاية (†). قال النحاس : " وقر أ أبو الدينار الأعرابى : ( الملك القَّوُس ) بفــتح

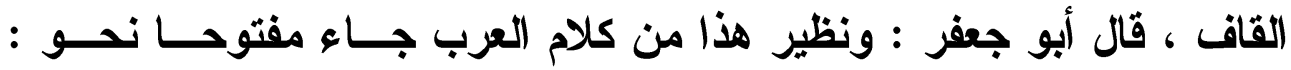

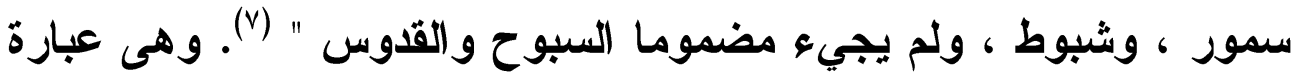

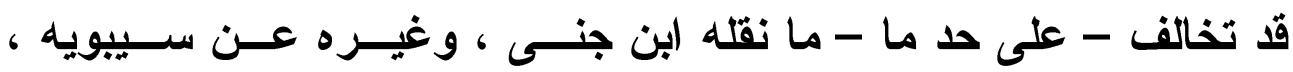

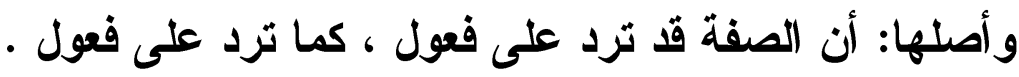

هذا ، وقد نقل الزبيدى حكاية اللحيانى الإجماع على ضم ( قـدوس )

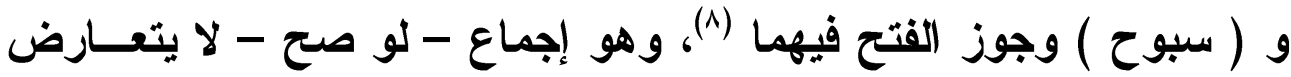

1 - الكثاف : IVV/r و ، وانظر أساس البلاغة : ص ه ه ؛ قس . • 1 - $1 / r-r$ . $r 01 / \Lambda-r$ ع •

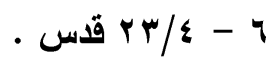

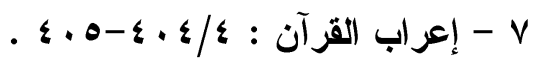

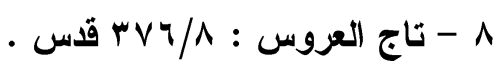




\section{الترقير الدولخ \\ ISSN 2356-9050}

مع أقوال من سبق ، إذ يصير بنا إلى جواز الوجهين، لا سيما وقــــ أنكــر

الأزهزى ما حكاه اللحيانى من الإجماع (1).

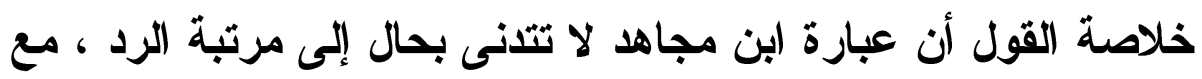

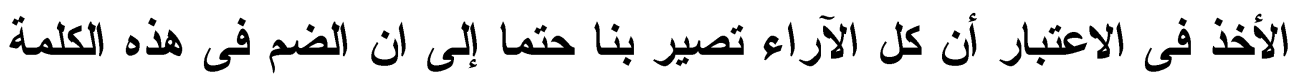

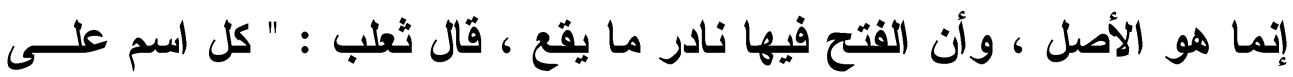

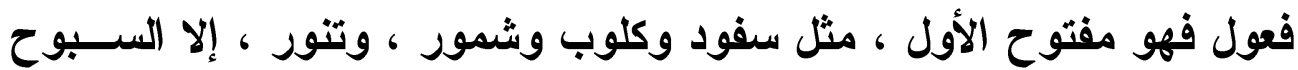

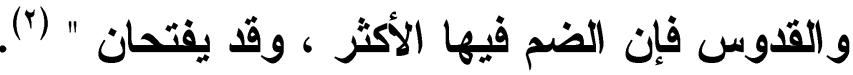
بل ما نص عليه (بن منظور أيضا ، قال : " وفعول - بالضــم - مــن

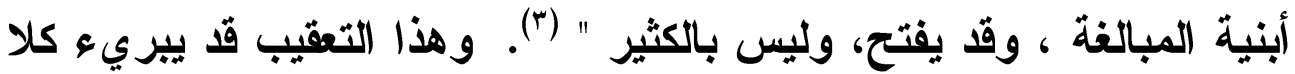

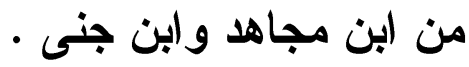
1- وقد آثرت هنا - أسوة بما وقع فى المستوى الصــوتى - خـتـ

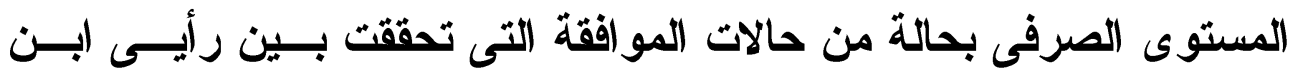

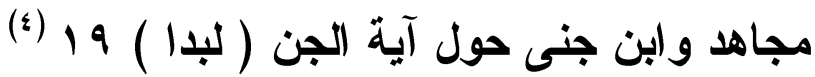

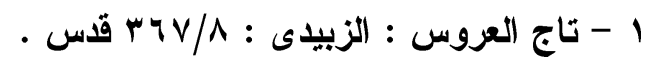

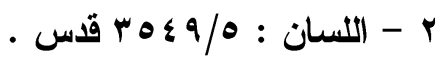

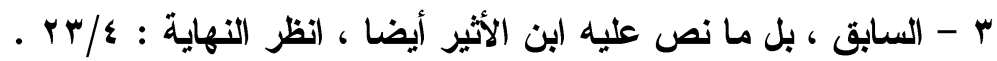

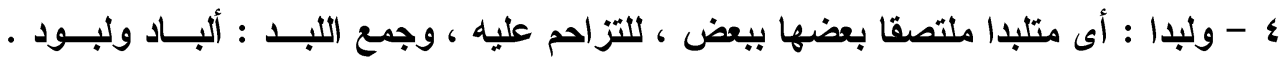

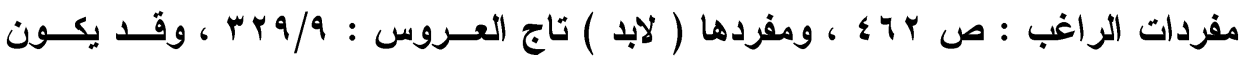

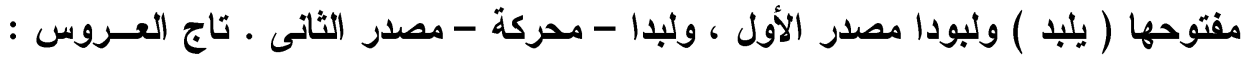

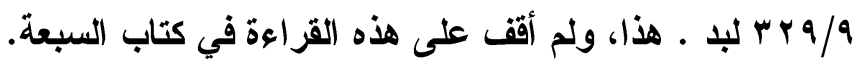


فقد روى ابن مجاهد عن عاصم الجحدى ( لبدا ) بضم اللام والباء ،

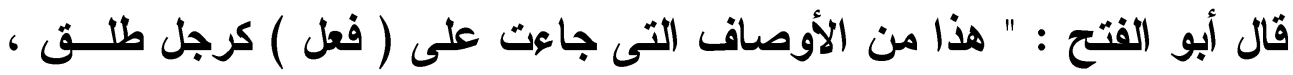

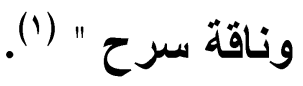

وقد نقل ابن خالويه هذه القراعة أيضا فى كتابه : ( إعراب القـــاءات

السبع ) قال : " وروى عن هارون ( لبلا ) بضمتين ، مثل : تمر " (؟).

كما سبق سيبويه إلى هذا البناء ( فعل ) على الرغم من ندرته ، قال :

" وأما الفعل فهو فى الصفات قليل " (").

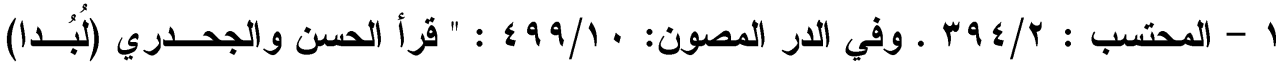

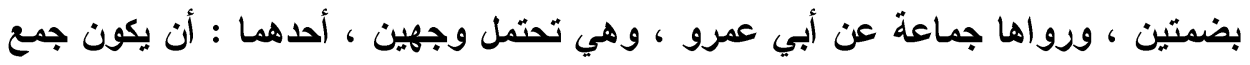

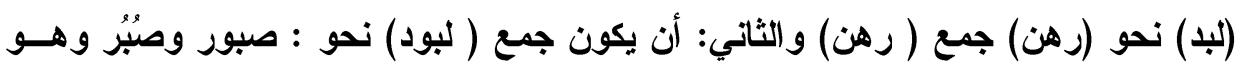

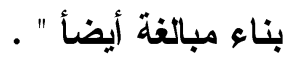

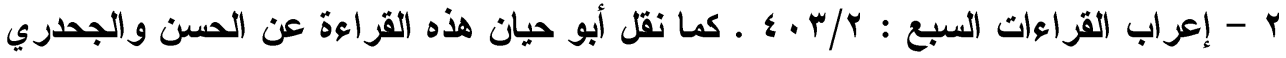
وأبو حيوة وجماعة عن أبي عمر ، نقلها أبو حيان عنهم بضمتين. انظر : البحر المحسيط :

$$
\begin{aligned}
& \text {. ror/A } \\
& \text { r - الكتاب : }
\end{aligned}
$$




\section{المستوى النهوي}

و المراد به السياق النحوى الأى ترد فيه الكلمة بوصفها وحدة نحوية،

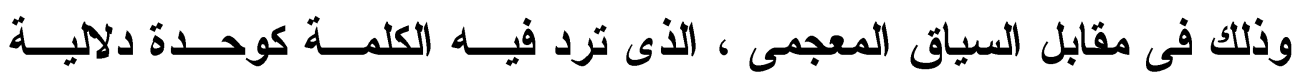

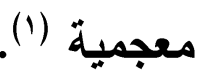

وقد كان يطلق على السياق النحوى قديما التركيب ، حيث لم تكن فكرة

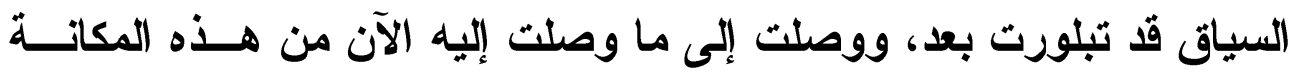

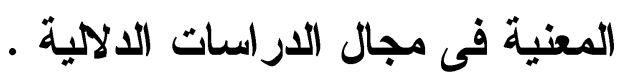

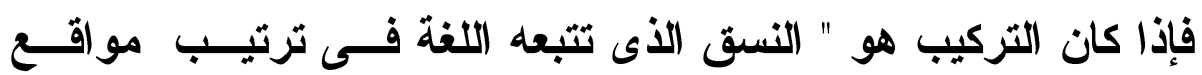

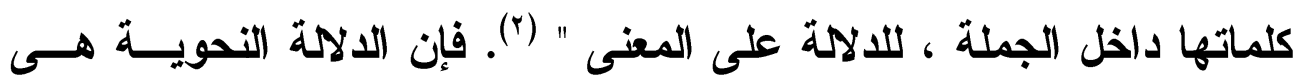

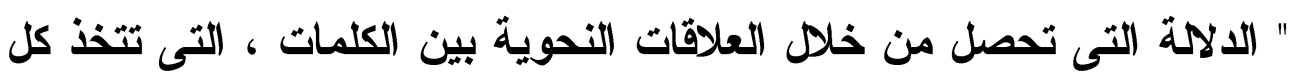

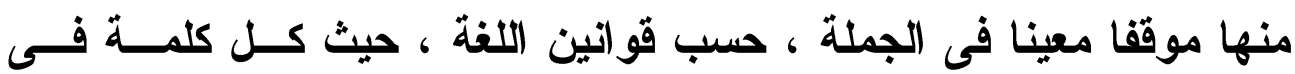

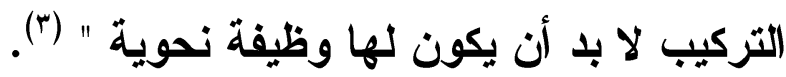

وكما خطا البحث فى المستويين العــابقين - الصـــوتى والصــرفى -

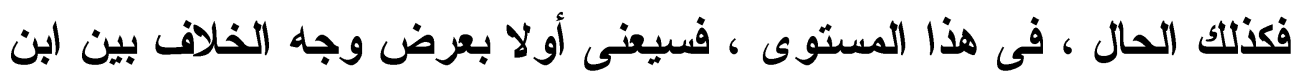

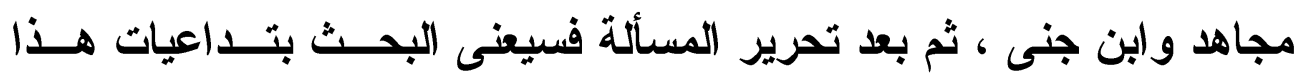

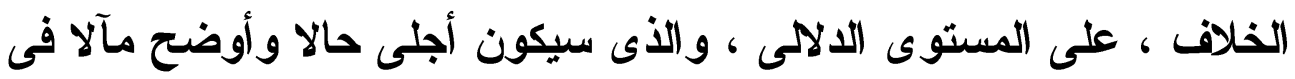

1 - العربية و الوظائف النحوية : د ـ ممدوح الرمالى ، دار المعرفة الجامعية - الإســكندية ،

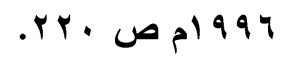

r - البحث اللغوى عند الأصوليين : دـ ـ ـ محد عادل خلف ، رسالة دكتوراة - آداب المنيــام

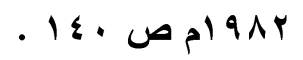

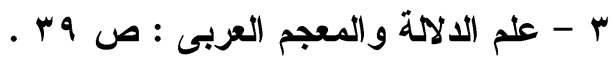

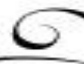


مناقشة ابن جني (بrara)

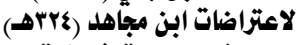

على بعض الروايات في المحتسب إنب

هذا المستوى بعينه ، إذ تتناوب المعانى المختلفة على التركيب الواحد وفق

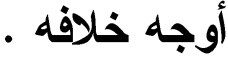

وأسوة بما سبق أيضا فقد صدرت الحديث فى هذا المستوى بمســائل الخلاف ثم أرجأت نماذج الموافقة إلى آخر العرض فـى هـــا المسـتوى ، سائلين الله - عز وجل - التوفيق والسداد .

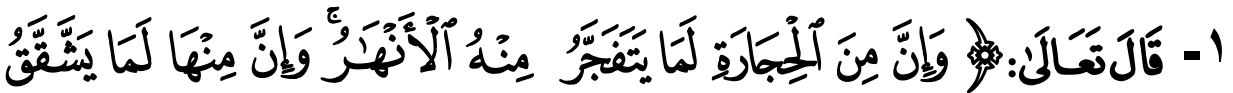

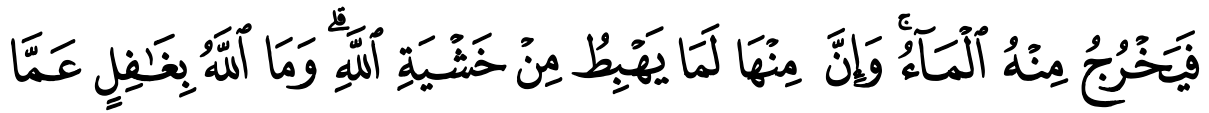
تََمَلُونَتَ

فقد أورد ابن جنى قراعة قتادة بتخفيف النون : ( وإن من الحجــارة ) وكذلك ( وإن منها ) مخففة.

فاعترض ابن مجاهد على تخفيف النون ، قائلا : " أحسبه أراد بقوله :

مخففة - الميم - لأنى لا أعرف لتخفيف النون معنى " (1).

فأجاب (بن جنى - كعادته - قائلا : " هذا الأى أنكــره ابـن مجاهــــ

$$
\text { صحيح " (r) }
$$

بعدها شرع ابن جنى فى التأصيل لما أنكره (بن مجاهد ، قائلا : " هذا الأى أنكره ابن مجاهد صحيح ، وذللك أن التخفيف فـى ( إن ) المكســورة

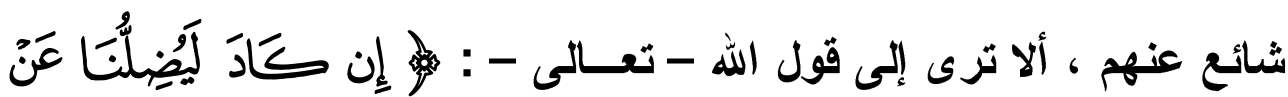

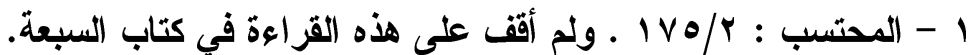




\section{الترقيم الدوله \\ ISSN 2356-9050}

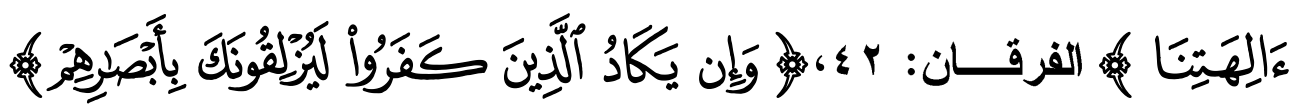
القلم: 101 ، أى : إنهم على هذه الحال .

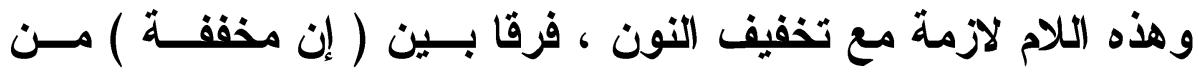

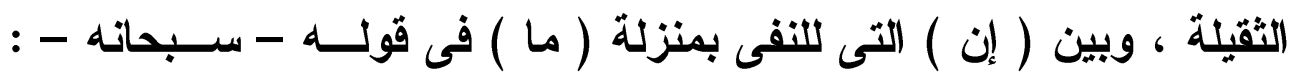

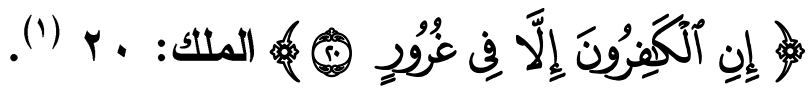
كما احتج على مذهبه بقول الثناعر :

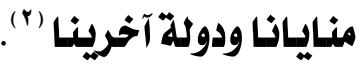

\section{وما إن طبنا جبن ولكن}

" فالطب العادة ههنا ، يقول : مالنا بالجبن عادة ، ولكن حضرت منيتنا

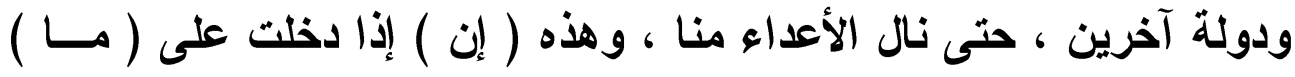

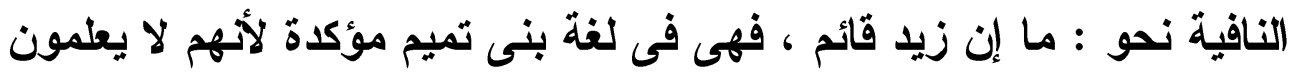

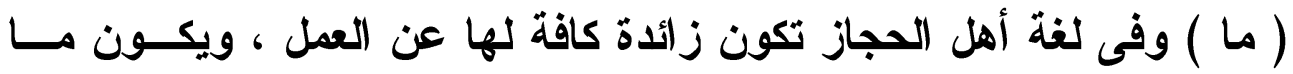

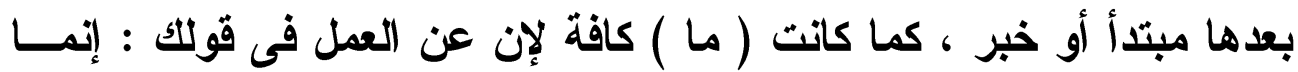

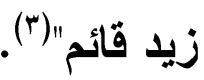

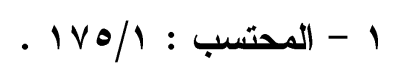

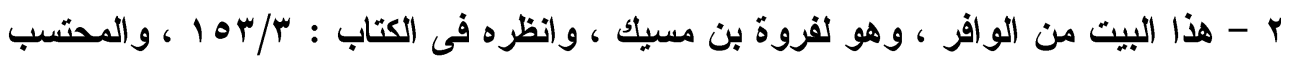

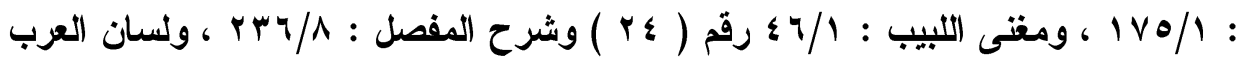

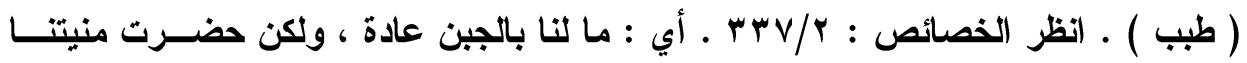
ودولة آخرينا ، حتى نال الأعداء منا.

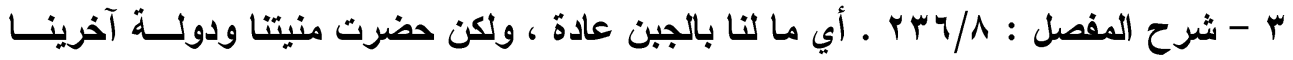
حتى نال العداء منا 


$$
\text { r - كما اختلفوا فى قوله - تعالى - : }
$$

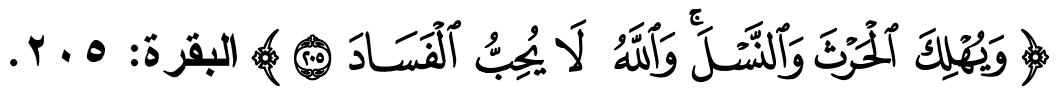

فقد نقل ابن جنى رواية هارون عن الحسن وابن أبى إســحاق وابـن محيصن ( ويهلك ) بفتح الياء واللام ، ورفع الكاف ، مع رفــع ( الحـرث والنسل ) على الفاعلية .

وقد رد ابن مجاهد هذه القراعة قائلا : " وهو غلط " (1).

وهنا أورد ابن جنى هذه القراءة بفتح الياء والــلام ورفــع الكــاف ،

وبالتالى رفع الحرث والنسل على الفاعلية ( ويهلك الحرث والنسل ) وقا رد ابن مجاهد هذه القراعة ، غير أنه لم يذكر وجه تخطئته لهذه القــراعة (r) . كما قرأ الحسن ( ويهلك) بضم الياء وإسكان الهاء وفتح اللام مبنيا للمفعول، وبرفع الحرث على أنه نائب فاعل ون

وربما كان سبب الرد ما أثنار إليه صاحب الكتاب : " وأمــا ( فعـل يفعل) فليس بأصل ، ومن ثم لم يجيء إلا مشروطا فيــهـ أن يكـون عينــه أو لامه أحد أحرف الحلق : الهمزة والهاء والحاء والعين والخاء والغـين ) إلا ما شذ من نحو : أبى يأبى ، وركن يركن " (؛).

1 - المحتسب : / / 1 / ـ و النص غير موجود بكتاب السبعة.

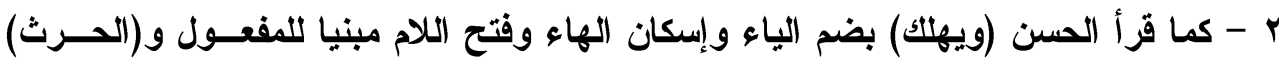

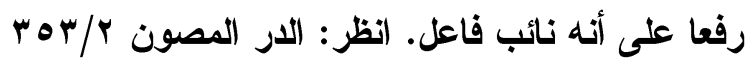
r - انظر: الدر المصون ؛ - شرح المفصل : rNV/V . بل هذا ما نص عليه السمين الحلبـي، قــال: " وفــتح عــين المضارع هنا شاذ، لقتح عين ماضيه، وليس عينه ولا لامه حرف حلى، فهو مثــل :ركـن فئن

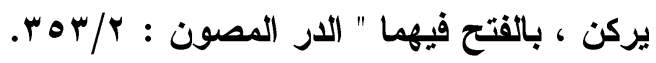




\section{الترقيم الدوله \\ ISSN 2356-9050}

وباستعر اض الامثلة التى استعان بها (بن جنى لتوضيح فكرته ، تجدها - كما ذكرها تماما - فى مظانها ، فقد ذكر منها سيبويه : أبى يأبى ، وجبى

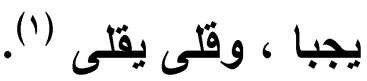

أما سائر الامثلة ، فقد أثنار إليها (بن منظور ، مع نصه على شــذوذ بعضها ، لخلوه من حروف الحلق ، قال - فى جبا يجبـــا - : " مــــا جــاء نادرا، مثل أبى يأبى ، وذلك أنهم شبهوا الألف فى أخره بالاهمزة فــى قـرأ

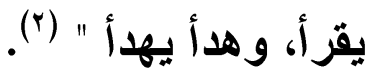
وعن ركن : " ركن يركن ، بفتح الكاف فى الماضى والآتـى ، وهــو

\section{نادر، وليست بفصيحة"(").}

وقال : " وكان أبو عمرو أجاز : ركن يركن ، بفتح الكاف من الماضى

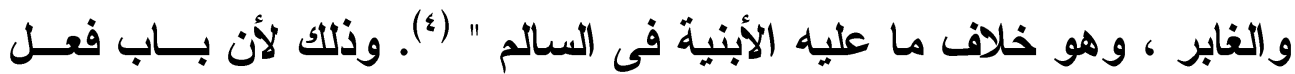
يفعل - بفتحتين - أن يكون حلقى العين أو الكلام" (0). وما قيل فى هذا ، قيل فى قنط يقنط ("). وقيل فى قلى يقلى (v). وقيـلـ فى غسا يغسو ، قال الزبيدى : " ومما يستدرك عليه : غسا الليل يغسـو ،

$$
\begin{aligned}
& 1 \text { - انظر الكتاب : \&/ه ـ 1-7 ـ 1 . } \\
& \text { r - لسان العرب : 1/1/ §ه جبى }
\end{aligned}
$$

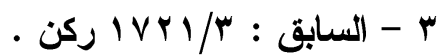

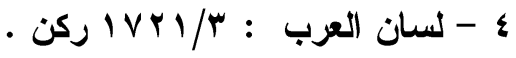

$$
\begin{aligned}
& \text { ه - هامش السابق : IVYI/r . }
\end{aligned}
$$

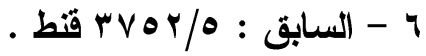

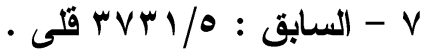




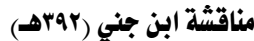

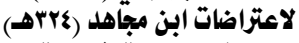

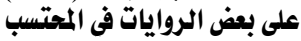

كابى يأبى ، حكاه ابن جنى ، لأههم شبهوا ألفه بهمزة فى قرأ يقرأ ، وهـــأ

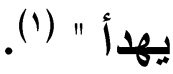

بل أضاف (بن جنى أنه قـ " يجوز أن يكون ( يهلك ) جاء على ( هلك) بمنزلة ( عطب ) غير أنه استغنى عن ماضيه بهلك " (r). مستعينا بقــراعة أبى السمال : ( فإن زللتم ) بكسر اللام ، قال أبو القتح : " هما لغتان : زللت وللت ، بمنزلة ضللت وضللت ، إلا ان الفتح فيهما أعلى اللغتين"("). ونظيره ما ذكره الأخفش فى اللسان : " وأما قنط يقنط - بالقتح فيهما - وقنط يقنط - بالكسر فيهما - فإنما هو على الجمع بين اللفتين " (؛). غير أن ابن منظور قد ذكر كلاما يرجح فى موضعه ما ذهب غليه ابن مجاهد ، وذلك حين حكم بالضمة لمضارع ( قنط ) بصورتى الضم والكسر ،

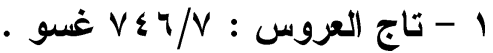

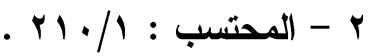

r - السابق • وقا كان للعرب في ماضي هذا الفعل ومستقبله ثلاثة مناهج : ا- ضلات أضل ، على وزن فعل يفعل ، وقد نسبه إلى تميم كراع وابن القطاع و إلى الحجاز اللحياني ، وعزاه

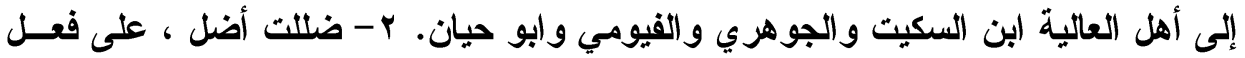

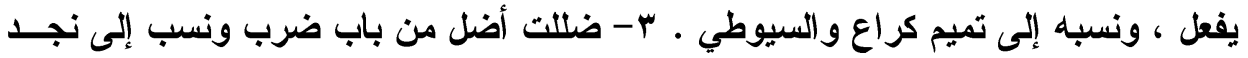

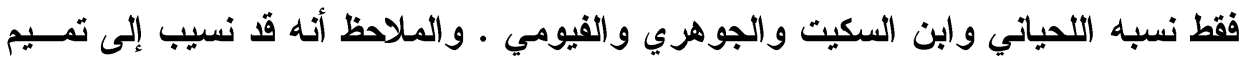
صيغتان ، الأولى والثانية، وإن كانوا يقصدون بنجد من يقيمون به من تميم وغيرهم فهـــا يعني أن التميميين كانوا ينطقون ضلانت أضل أيضا ـ انظر :لغـة تمـيم دراســة تاريخيـة

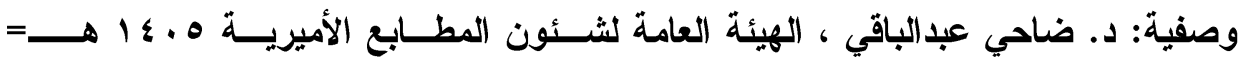

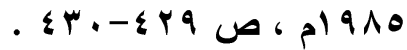

$$
\begin{aligned}
& \text { ع - اللسان : rvor/0 قنط . }
\end{aligned}
$$




\section{الترقيم الدوله \\ ISSN 2356-9050}

لا القتح ، فقال بعد أن ساق مذهب ابن جنى بفتح النون فى الماضى والآتى

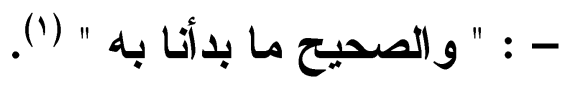$$
\text { يقصد : قنط يقنط - بالكسر - وقنط يقنط - بالضم . }
$$

ولعل القول باختلاف اللغات هو المخرج مما نحــن فيــهـ ، قــال فـى اللسان: " وفيه لغة ثالثة : قنط يقنط قنطا .... وأما ق نط يق نط - بــالقتح فيهما، وقنط يقنط - بالكسر فيهما - فإنما على الجمع بين اللغتـين ، قالـــهـ

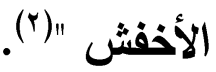

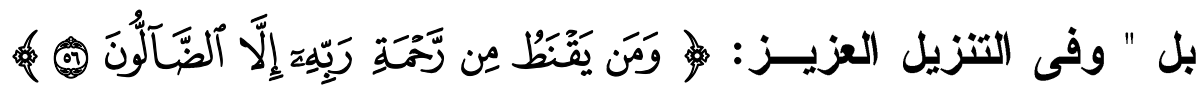

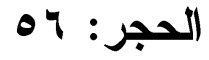

، وقريء : ومن يقنط ـ قال الأزهرى : وهما لغتان : قـنط يقـط ،

وقنط يقنط ، فى اللفتين ، قال : قال ذللك أبو عمرو بن العلاء " (r). هذا، وقد قرأ (يقنط) بكسر النون حيث وقع أبـو عمــرو والكســائي ويعقوب والوجه أنه مضارع ( قنط) بفتح النون (يقنط) بكسرها مثل( كسر يكسر) ، وهي اللغة المشهورة العليا، يال على ذلك اتفاق القراء على الفتح

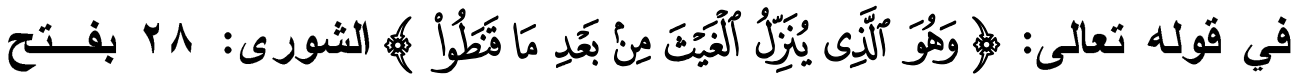

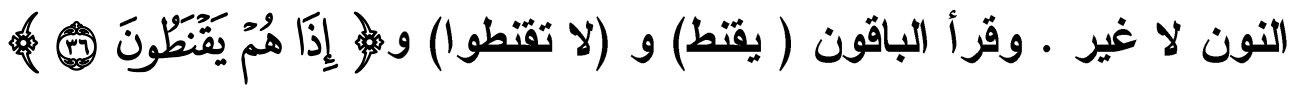
الروم: צr بقتح النون حيث وقع. وتأويله أنه مضارع (قنِط) بكسر النون ، 


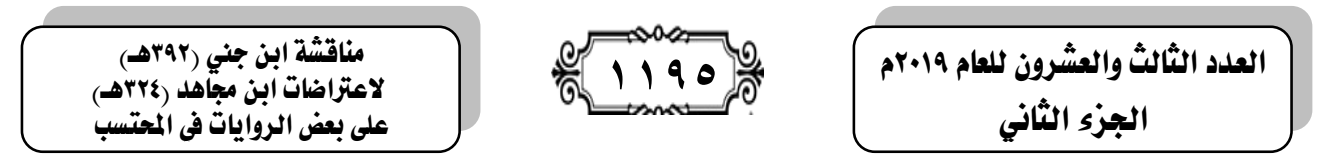

وقنِط وقَط بالكسر والفتح لغتان مثل نقِم ونقَم (1) ـ و اللغة الأولى - بكسر

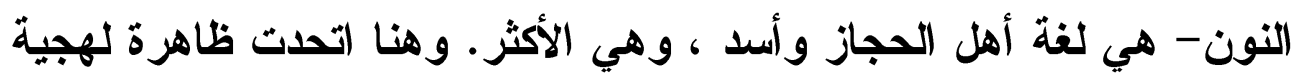

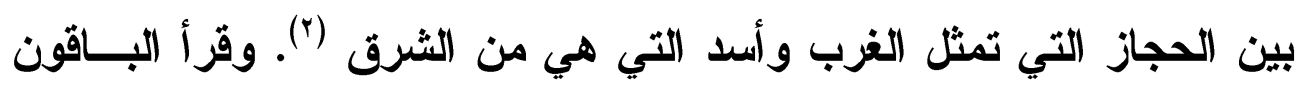

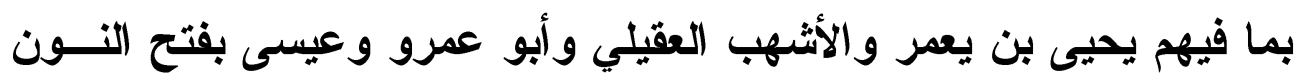

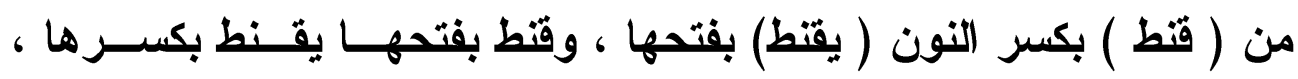
لغتان (")

بل ليس من الصواب إغفال أمر كهذا كالقول باختلاف اللغــات ، وقــــ

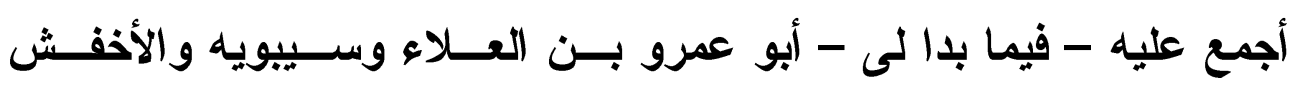

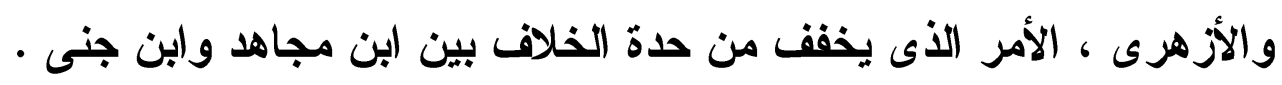
و الساحة - كما تبدو للمتلقى - ميدان مزدحم بالآراء الصرفية ، غير

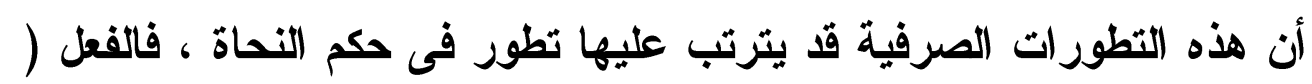

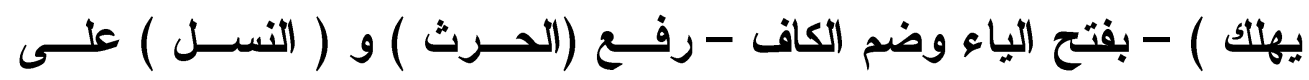

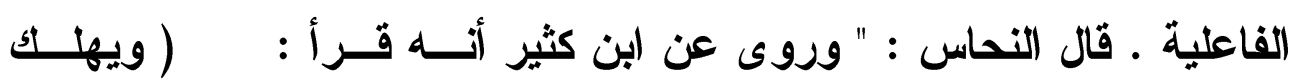

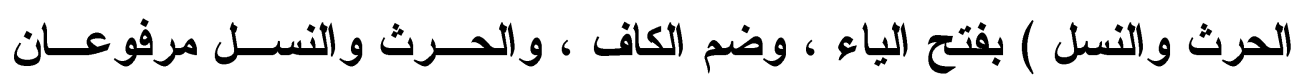

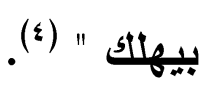

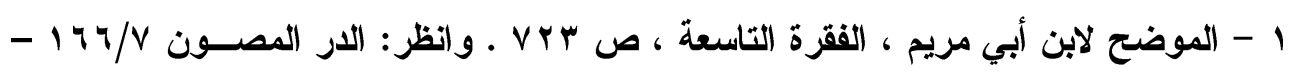
$.17 \mathrm{~V}$

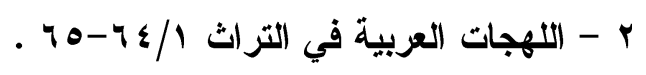

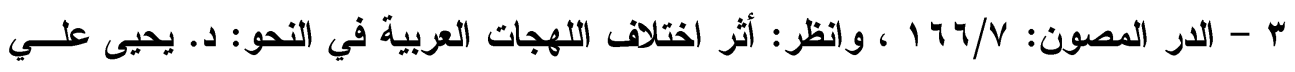

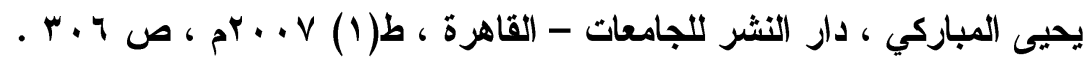

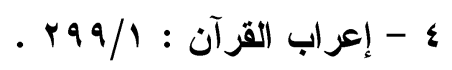




\section{الترقير الدولخ \\ ISSN 2356-9050}

وكذلك ما رواه هارون عن الحسن ( ويهلك ) بفتح الياء واللام ورفع

الكاف ، الضبط الأى يقتضي أيضا الرفع فى ( الحرث ) و ( النسل ) علـى

(اعاعلية (1)

أما قراعة حفص فقد عدى الفعل فيها بالهمزة ، فصار ( أهلك يهلك ) التغير الصرفى الأى يترتب عليه نصب ( الحرث والنسل ) على المفعوليـة وهذا يذكر بما سبق رصده مــن " أن الـــرس الصــرفى مقدمــة للــدرس النحوى، لأن اهثمام الصرف بينية الكلمة إنما هو من أجـلـل توظيفهـــا فــى

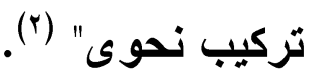

وربما تعجب الباحث من عبارة ابن مجاهد - وهو يعقب على مـذهب

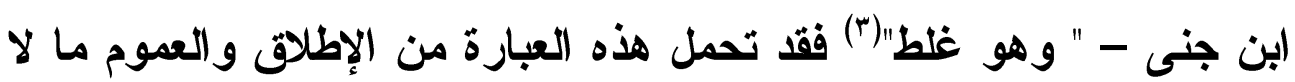
يليق بابن جنى ، وقد أغرق مسائل الخلاف كلها حجة وعلما ، وكفــاه فـى هذه المسألة أنه أمطر ابن مجاهد بالعديد من النظائر الصرفية التى تـرجح مذهبه

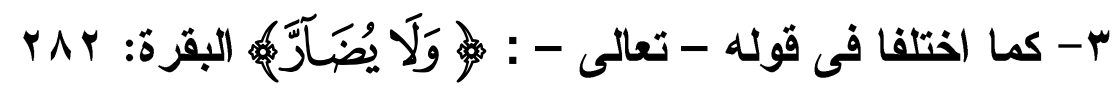
فقد قر أها (بن محيصن : ( ولا يضارٌٌ ) بالرفع . قال (بن مجاهد : " لا

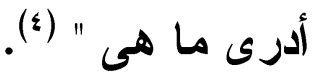

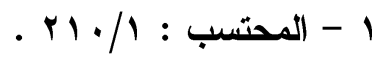

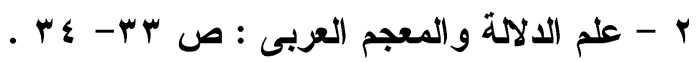
r - المحتسب : ع - ولم أقف على هذه القراعة في كتاب السبعة. 
قال ابن جنى : " وهذا الذى أنكره (بن مجاهد معروف، وذللك أن تجعل

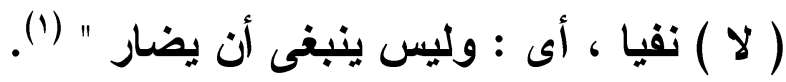

\section{وهنا طرح ابن جنى لهذه الآية ثلاث قراعات (†):}

الاولى : قراعة عمرو بن عبيد وابى جعفر يزيد بـن القعة اعـاع : ( ولا

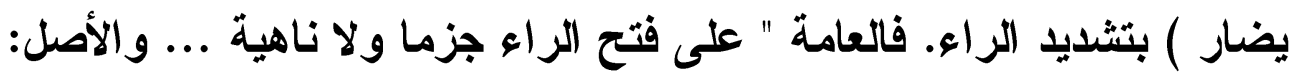

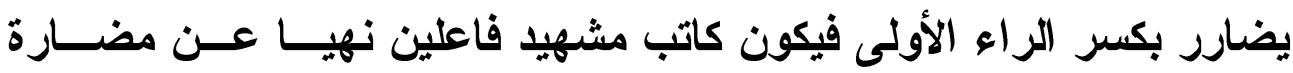

$$
\text { المكتوب له و المشهود له " (r). }
$$

الثانية : قراعة عمرو بن عبيد وابى جعفر يزيد بن القعقــاع أيضـــــا :

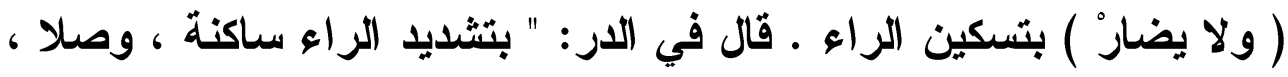

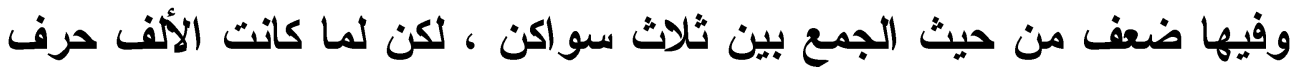

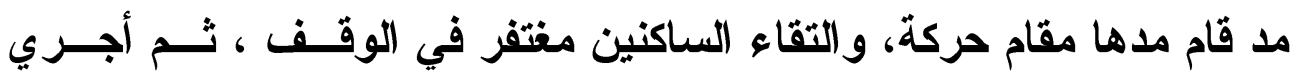

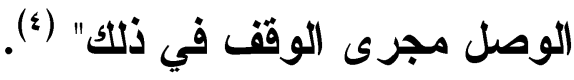

الثالثة : قر اعة ابن محيصن : ( ولا يضارة ) بــالرفع مــع التثــديد .

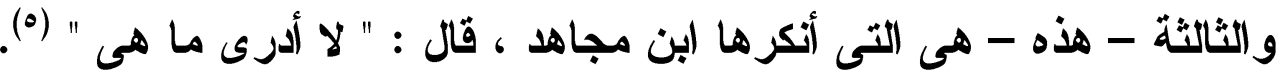

$$
\begin{aligned}
& 1 \text { - السابق : 1 / } \\
& \text { r - انظر : السابق - الم }
\end{aligned}
$$

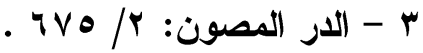

$$
\begin{aligned}
& \text { צ - السابق: ז/ } \\
& \text { ه - المحتسب : اله }
\end{aligned}
$$




\section{الترقير الدولخ \\ ISSN 2356-9050}

وقال السمين الحلبي : " برفع الراء وهو نفي ، فيكون الخبر بمعنـى

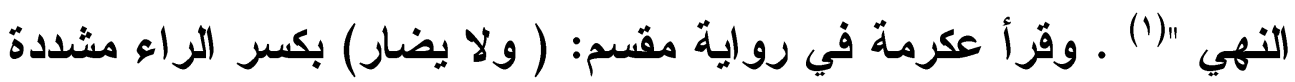

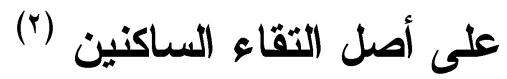

وقد رد عليه ابن جنى إنكاره ، محتجا بشهرة هذه القراعة ، قــائلا : "

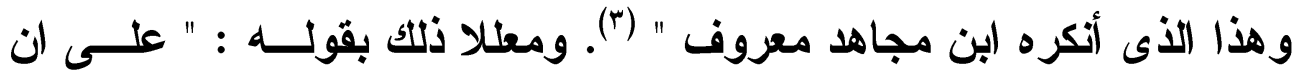
تجعل ( لا ) نفيا ، أى : وليس ينبفى أن يضار" (4) مجأ.

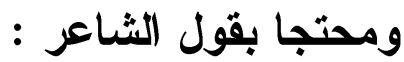

قضيته ألا يجورويقصدُ (0). على الحكم المأتى يوما إذا قضى

وما ذهب إليه سيبويه والأخفش وابن منظور فى هذا البيت ذهب إليه

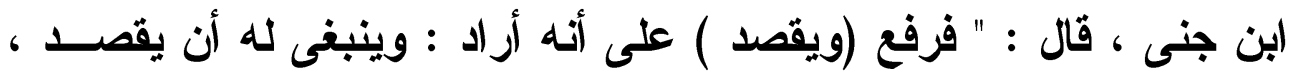

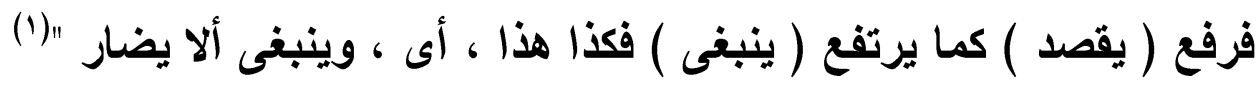

$$
\begin{aligned}
& 1 \text { - الار المصون: Y T T T } \\
& \text { r - السابق : TVV/ } \\
& \text { r - المحتسب : } \\
& \text { ع - السابق - }
\end{aligned}
$$

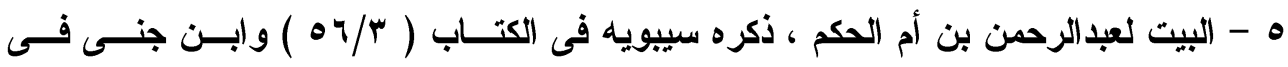

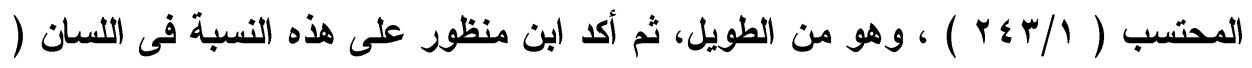

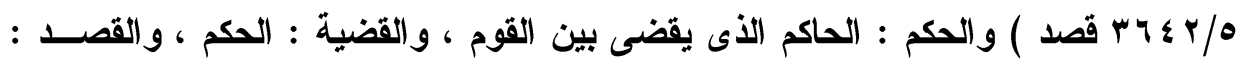

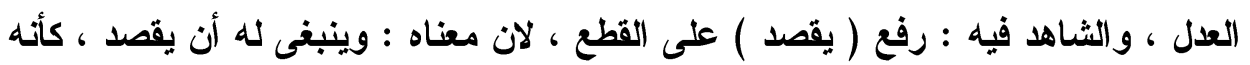

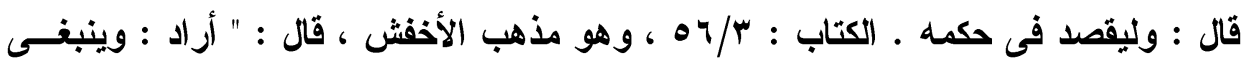

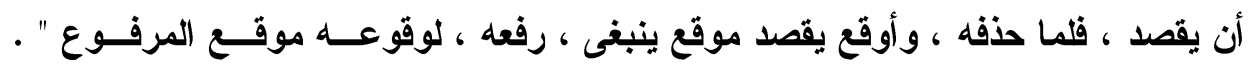

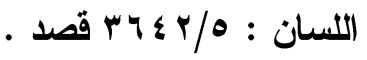

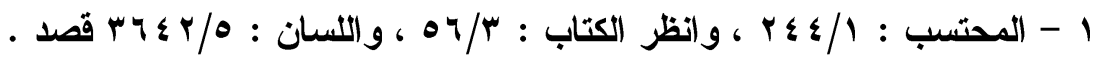


مناقشة ابن جني (بrara)

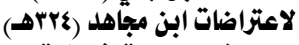

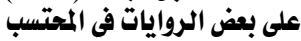

بل أتى ابن جنى بنظير هذه الآية ، مما جاء بلفظ الخبر ومعناه الأمر ،

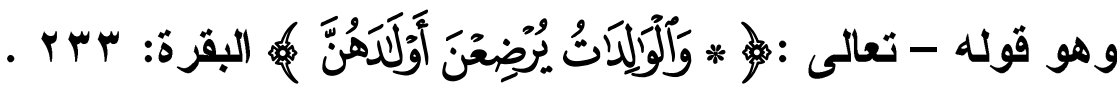

قال ابن جنى : " أى : ليرضعن ". (1)

كما أكد هذا المفهوم فى رده على ابن برى ، الأى كان يرى أن معنى البيث : " على الحكم المرضى بحكمه المأتى إليه ليحكم ألا يجور فى حكمه ، بل ، يقصد ، أى : يعدل ، ولهذا رفعه ، ولم ينصبه ، عطقا على قوله ( ألا

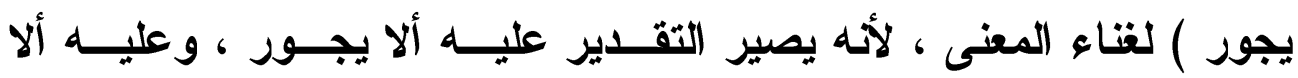

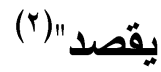

قال ابن جنى - يرد على مفهوم ابن برى - : " وليس المعنــى علــى ذللك ، بل المعنى : وينبغى لله أن يقصد ، وهو خبر بمعنسى الأمسـر ، أى :

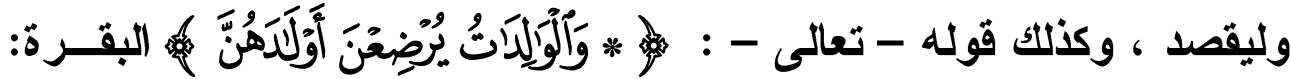

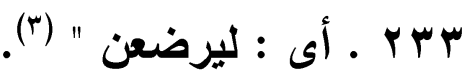
بل وسع ابن جنى دائرة البسط ، فقال : " وإن شئت كان لفــ الخبــر

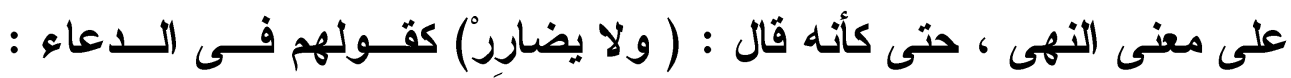
يرحمه الله ، أى ليرحمه الله ، ويغفر الله للك، أى : وليغفــر الله لــــ ، ولا يرحم قاتلك ، فرفع على لفظ الخبر ، وأنت تريل : لا يرحمـهـ الله جزمــا ، فتأتى بلفظ الخبر ، وأتت تريد معنى الامر ، والنهى على ما ذكرنا " (1).

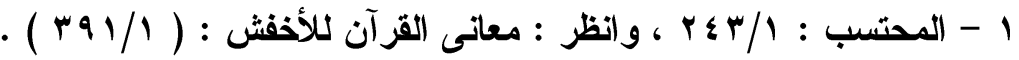

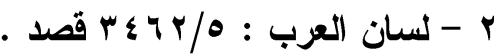

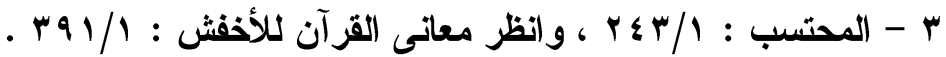

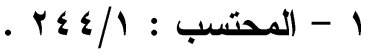

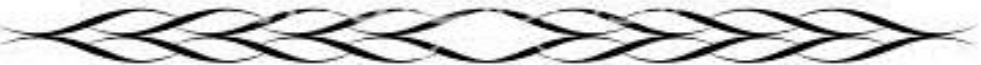




\section{الترقيم الدولم}

ISSN 2356-9050
T.

حولية كلية اللفة العربية بجرجا مجلة علمية محكمة الفية

فتأمل كيف كان إلمام ابن جنى بمثل هذه القضايا ، وقصور المخالفين عن إدرالك وثبته عادة ، وكأنه لا يبارى .

وأخيز إنان هنالك قراعة ثالثة للأعمش ، نقلها النحاس فـى إعــراب القرآن - بكسر الراء - (ولا يضارِّ كاتب ولا شهيد ) قال أبو جعفر : " كسر الراء لآتقاء الساكنين ، وكذلك من فتح ، إلا أن الفتح أخف " ( ).

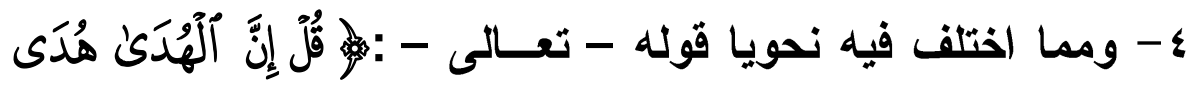

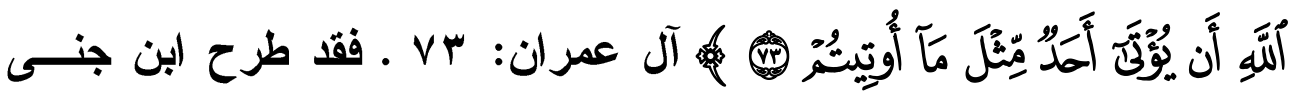
قراعة الحسن : ( أن يؤتى أحدٌ مثل ما أوتيتم ) فاعترض ابن مجاهد ، قائلا:

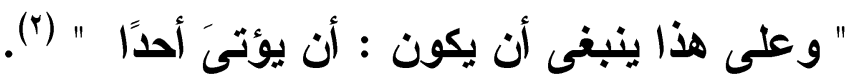
وهنا رد ابن جنى على ابن مجاهد إنكاره ، قائلا : " لا وجه لإنكار (بن مجاهد رفع ( أحد ) مع قوله ( يوتىَ) ) مسمى الفاعل ، وذلك أن معناه : أن يؤتى أحد أحدا مثّل ما اوتيتم ، كقولك : أن يحسن أحد مثل ما أحسن إليكم ، أى : أن يحسن أحد إلى احد مثل ما أحسن إليكم ، فتحذف المفعول، ويكون معناه ومفاده : أن نعمة الله - سبحانه - لا تقاس بها نعمة " (").

وما ذكره ابن جنى نص عليه - بتمامه - (بن عطية ، قال : " وقـرأ الحسن : ( أن يؤتِى أحد) بكسر التاء ، على إبــناد الفعـلـ إلــى ( أحـــ )

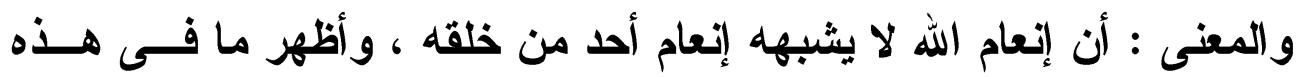

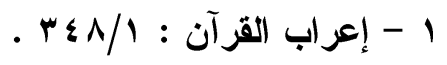

r - المحتسب : 1/. بr ـ ولم أقف على هذه القراعة في كتاب السبعة .

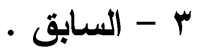




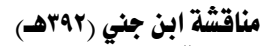

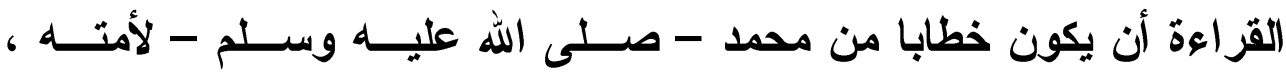
و المفعول محذوف ، تقديره : أن يؤتى أحد أحدا " (')

ه- كما أنكر ابن مجاهد على ابن جنى - نحويا - قراعة الحلوانى عن قالون عن شيبة : ( أو آوى ) هود: ، ^ ، بقتح الياء ، قال (بن مجاهـــ : "

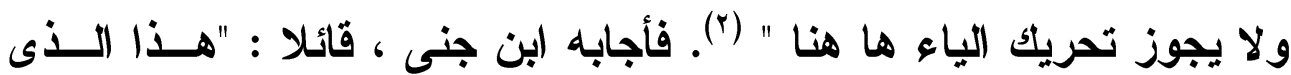

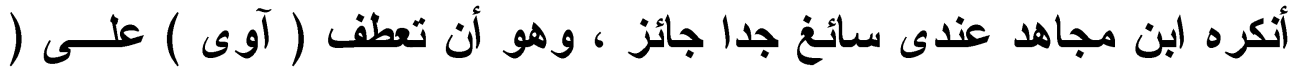
قوة ) ، فكأنه : قال ( لو أن لى بكم قوة أو أويَّا إلى ركن شديد ) فإذا صرت إلى انتفاء المصدر ، فقد وجب إضمار ( أن ) ونصب الفعل بها " (־). كما احتج ابن جنى لمذهبه بقول قيسون بنت بحل الكليبية ، وهو من

أى : لأن ألبس عباءة وتقر عينى أحب إلى من كذا (1).

$$
\begin{aligned}
& 1 \text { - البحر المحيط : 9V/r ؛ . } \\
& \text { r - المحتسب : } \\
& \text { • }
\end{aligned}
$$

؛ - البيت لميسون - كما سبق - وهى بنت معاوية بن أبى سفيان ـ وكاتت بلوية ، فضــاقت نفسها لما تسرى عليها ، فعذلها على ذللك ، وقال لها : أنت فى ملك عظيم ، ومـــا تـدرين

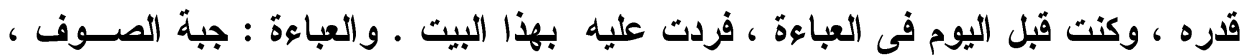
قرت عينه : بردت كناية عن السرور والرضا ، الشفوف : جمع شف بالكسر ، وهو الثوب

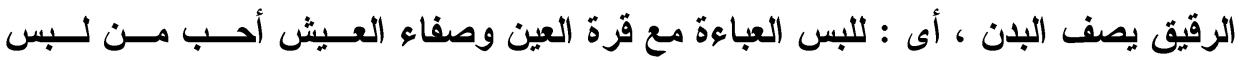

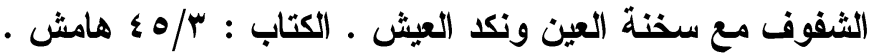

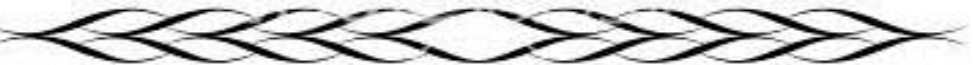




\section{الترقيم الدوله}

ISSN 2356-9050
Q
حولية كلية اللفة العربية بجرجا مجلة علمية محكمة

وهو ما نص عليه سيبويه:" لما لم يستقم أن تحمل ( وتقر) - وهــو

فعل - على (لبس ) وهو اسم- لما ضممته إلى الاسم ، وجعلت أحب لهمـــا

ولم ترد قطعه ، لم يكن بد من إضمار أن" (1").

بل نص عليه محقق الكتاب ، إذ يقول : " والشاهد فيه ( نصب تقــر ) بإضمار ( أن ) بعد الواو ، ليعطف على اللبس ، لأله اسم ، وتقر فعل ، فلم يمكن عطفه عليه ، فتحمل على إضمار (أن) لأن أن وما بعدها اسم ، فعطف اسما على اسم ، وجعل الخبر عنهما واحدا وهو نصب : أحب"(؟). بل ودعم سيبويه (ץ) هذا الشاهد بأمثلة أخرى منها :

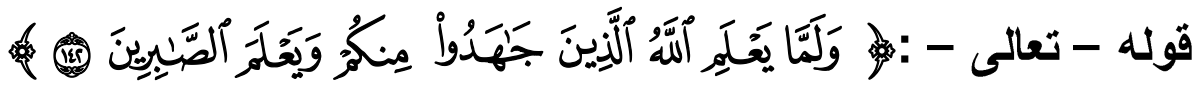
آل عمران: ب ؛ أ. والنصب قراعة الجمهور .

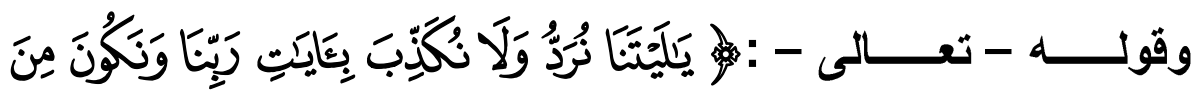

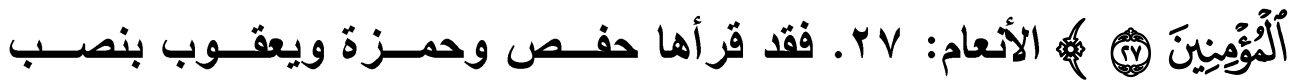
( نكنب ) و ( نكون )

قال ابن يعيش : " فأما النصب - وهو قراعة حمزة وابن عامر وحفص - فعلى معنى الجمع، والتقدير : يا ليتنا يجمع لنا الرد وترك التكذيب والكون من المؤمنين ، ويكون المعنى كالوجه الاول فى دخولها فى التمنى ، ويكون التكذيب على رأى من يرى التمنى خبرا " (1)

$$
\begin{aligned}
& 1 \text { - الكتاب : آ } \\
& \text { r }
\end{aligned}
$$

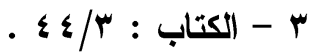

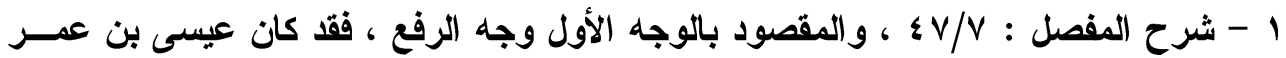

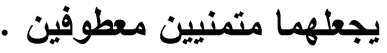




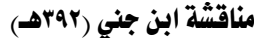

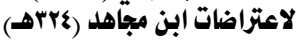

على بعض الروايات في الماحتسب مئ

هذا ، وقد ذهب ابن يعيش - فى تأويل هذا البيت - مذهبا فيه قر من

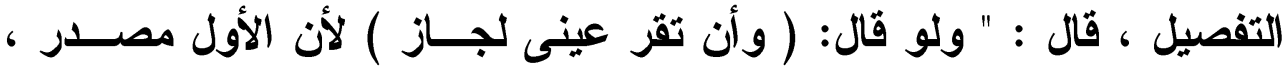

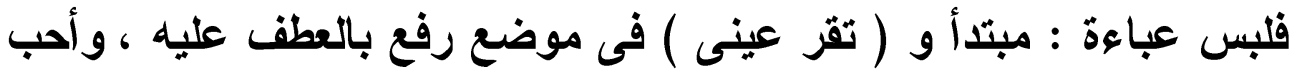
إلىى : الخبر عنهما ـ والمعنى : أن لبس الخشن من الثياب مع قـــرة العـين

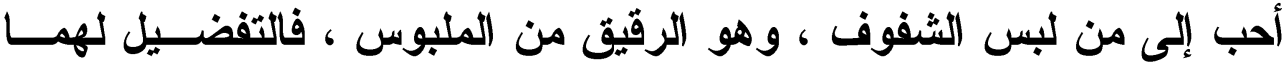
مجتمعين على لبس الثفوف ، ولو انفرد أحدهما بطل المعنى ، الأى آراده ، إذ لم يكن مراده أن لبس عباءة أحب إلى من لبس الثــفوف ، فلمـــــــــان المعنى يعود إلى ضم ( تقر عينى ) إلى ( لبس عباءة ) اضطر إلى إضــمار

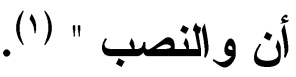

ولو تركنا مذهب النحاة إلى مذهب المفسرين فالأمر لا يختلف البتــة ،

قال الزمخشرى : " وقريء (أو آوى ) بالنصب ، بإضمار ( أن) كأنه قيل :

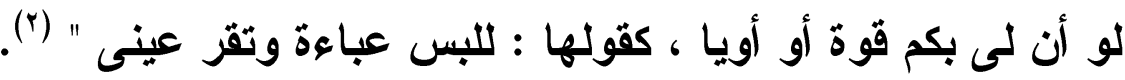
وقال أبو حيان : " وقرأ شيبة وأبو جعفر ( أو آوىَ ) بنصب اليـاء ، بإضمار ( أن ) بعد أو ، فتقدر بالمصدر ، عطفا بالمصدر على قوله ( قوة ) (ץ)"

وكعادة ابن جنى فى إمطار خصمه بوابل من الثــواهد التـى تــــمم مذهبه، فقد احتج لمذهبه هذا بشاهد من الكتاب : فلولا رجال من رزام أعزة آل سبيع أو أسوءك علقما

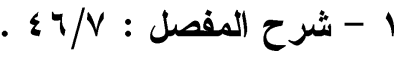
. $11 / r: r$ r - البحر المحيط : 0V/0 1 ، بتصرف يسير .

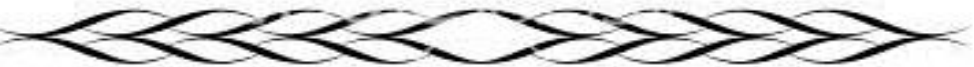




\section{الترقيم الدولي}

ISSN 2356-9050

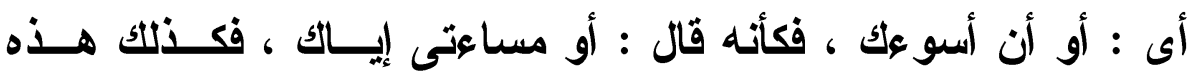

القزاعة : لو أن لى لكم قوة أو أويا ، أى : أو أن آوى إلى ركن شديد (').

قال سيبويه : " يضمر ( أن ) وذلك لأنه امتنع أن يجعل الفعـل علــى

( لولا ) فأضمر( أن ) كأنه قال: لولا ذالك ، أو : لولا أن أسوعك " (r).

فأى شيء بقى لابن مجاهد يواجه به هذا الحشد اللغوى الهائل من ابن جنى ، والمدعم بآراء اللغويين والنحويين والمفسرين ، وإن كــان الســياق الأى ساقه ابن جنى لقضايا الخلاف كلها مسوقا لخدمة مذهب (بن جنى ، وحسب ، أعنى أن يكتفى بعرض آراء ابن مجاهد عارية من أدنى حجـة أو دليل، ثم بعد ذلك يسوق آراعه بالكيفية التى تروق لله ، وتخدم فكرتـــه مـــع الصفح الكامل عن أى تعقيب يعقب به ابن مجاهد على حجة ابن جنى • بـلـل مع الجهل الكامل بملابسات المناقشة والمواجهة ، فلربما كان للحكم شــأن آخر لو استوفى المتلقى أدنى تعقيب لابن مجاهد على حجة ابن جنى .

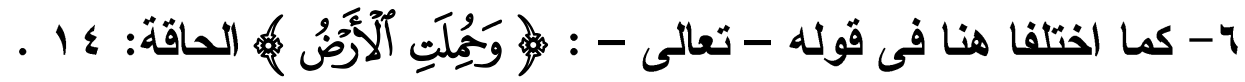
فقد نقل ابن جنى عن ابن عامر ( وحمّت الأرض ) مشددة الميم ، قال ابن مجاهد : " وما أدرى ما هذا " (") قال ابن جنى : " هذا الذى تبشع على ابن مجاهد حتى أنكره من هذه القزاعة صحيح وواضح " (؟).

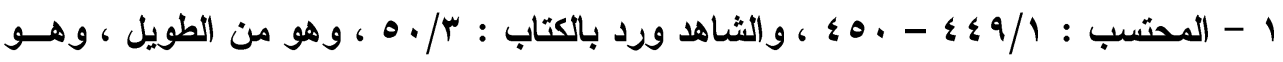

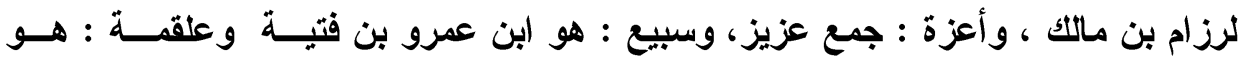

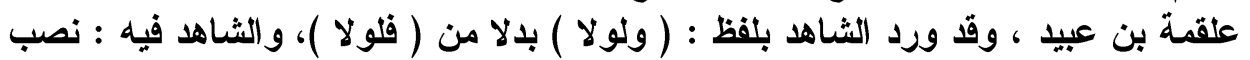

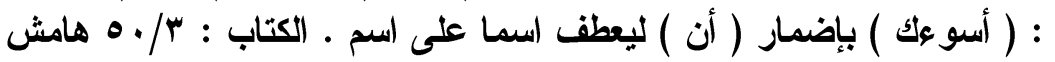
r

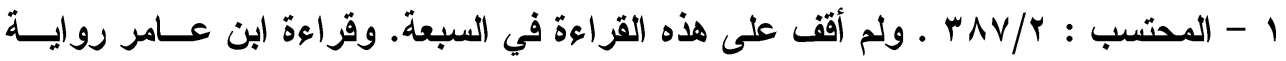

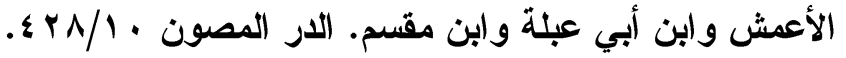

\section{0}




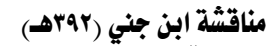

هذا وقد ساق أبو حيان القراعتين ، موجها لهما ، دون أدنــى عنــاء

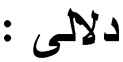

فقراعة الجمهور : ( وحملت ) بتخفيف الميم ، وقـراعة (بـن عــامر

بتثديدها ، فالتخفيف على أن تكون الأرض والجبال حملتها الريح العاصــف

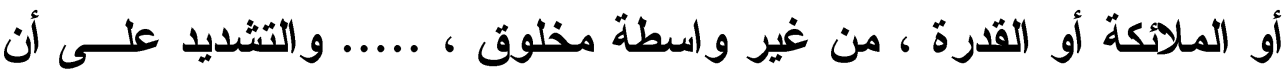
تكون للتكثير ،فلم يكسب الفعل مفعولا آخر، أو يكون التضعيف للنقل ، فجاز

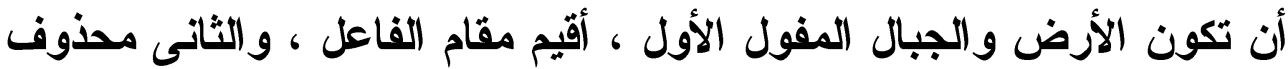
أى : ريحا تفتتها أو ملائكة أو قرة .

وجاز أن يكون الثانى أقيم مقام الفاعل ، والأول محذوف ، وهو واحد

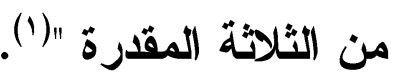

كما أضاف ابن جنى - تلاعيما لمذهبه هذا - بعض الأمثلة التى تكافئ

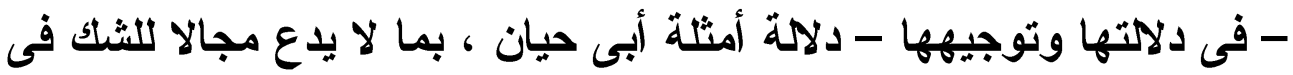

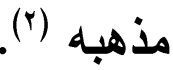

V- وهنا اعترض ابن مجاهد على فتح الحاء من كلمة ( نشرح ) فى

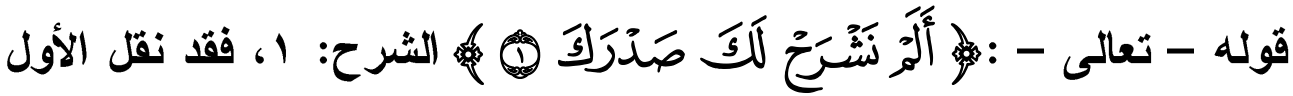

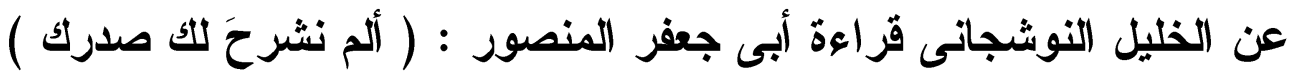

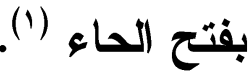

$$
\begin{aligned}
& 1 \text { - انظر : البحر المحيط : 1 ا I I . . }
\end{aligned}
$$

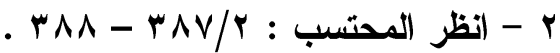

$$
\begin{aligned}
& 1 \text { - السابق : ب/ ع بـ . }
\end{aligned}
$$




\section{الترقير الدولخ}

ISSN 2356-9050

$\frac{0}{1+1.7}$

قال ابن مجاهد : " وهذا غير جائز أصلا " (1). نقل الســين الحلبـي توجيها لهذه القراءة عن الزمخثري خلاصته أنه:" لعله بين الحاء وأثبعها في مخرجها فظن السامع أنه فتحها" (r). أما ابن جنى فقد استهل المفاصلة بإقرار ابن مجاهد على ما ســبق ، من جهة أن هذا " غير جائز أصلا " غير أنه قد ورد فى الشعر ، وعلى نحو ما جاء فى نوادر أبى زيد، وهو من الرجز :

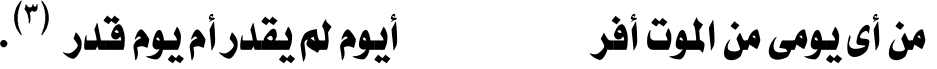

" قيل : لم يقدرًا ، بالنون الخفيفة ، وحذفها ، وهذا عندنا غير جائز ،

وذلك أن هذه النون للتوكيا ، والتوكي أثببه شيء به الإسهاب والإطناب ، لا الإيجاز والاختصار ، ولكن فيه قول ذو صنعة ، وقــــ ذكرتـــه فــى كتــابـى

الموسوم : سر الصناعة " (๕)

نعم ، ذكره ابن جنى فى كتابه ( سر صناعة الإعراب ) (') وأنكر حذف

النون الخفيفة للضرورة.

قال : " هذه النون لا تحذف إلا لسكون ما بعدها ، ولا سكون هاهنــا

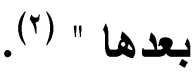

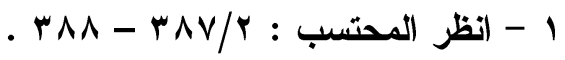

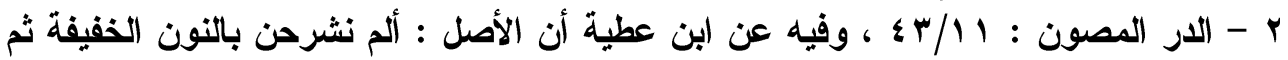

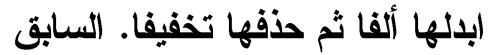

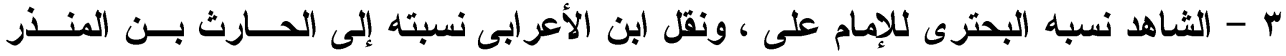

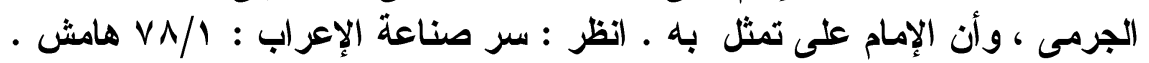

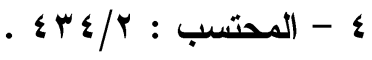

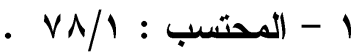

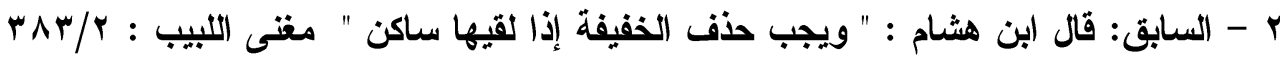

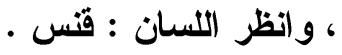


مناقشة ابن جني (بواتهـ)

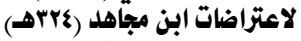

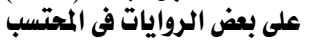

إذن فما العلة التى يراها ابن جنى جديرة بحذف النون الخفيفة ؟ يرى ابن جنى أن أصل الشاهد : " أيوم لم يقدر أم " بسكون الراء من ( يقدر ) للجزم ، فلما جاورت الراء الساكنة الهمزة المفتوحسة مسنـ ( ام ) أجريث الر اء الساكنة مجرى المتحرك (')، فتحركت ، وصار التقدير كأنه : " أيوم لم يقدر أم " فتسكن الهمزة وقبلها الراء مفتوحة ، فتقلب الهمزة ألفــا للتخفيف ، فيصير التقدير : " يقدر أم " فتأتى الألف ساكنة ، وبعدها المــيم

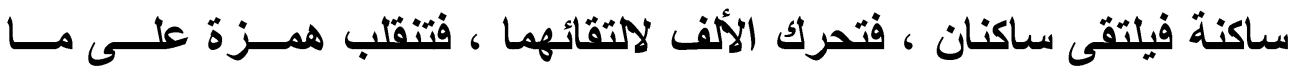
ذكرنا ، و تقتحها لاتقائهما ، وكان القتح هنا حسنا اتباعا لقتحة الراء " (r). ليس ذللك فحسب ، بل أضاف ابن جنى إلى رصيد شواهده لهذا المذهب : شاهدا آخر ضربك بالسيف قونس الثرس (1). اضرب عنك الهموم طارقها

قال ابن جنى : " فقالوا : اضربا ، بالنون الخفيفة ، وحذفها " (ץ)

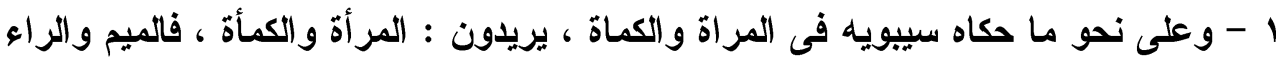

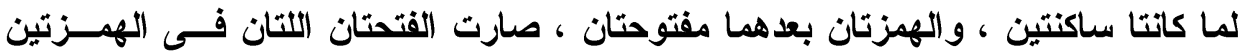

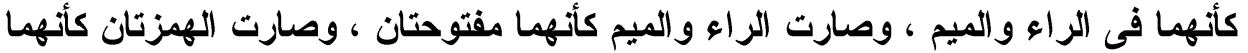

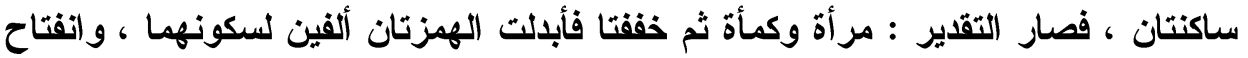

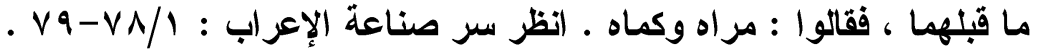

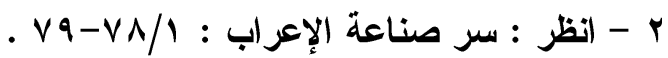

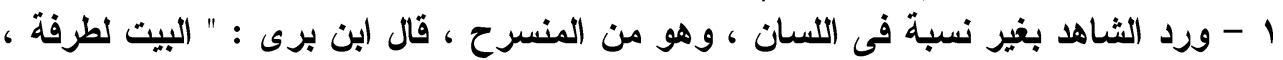

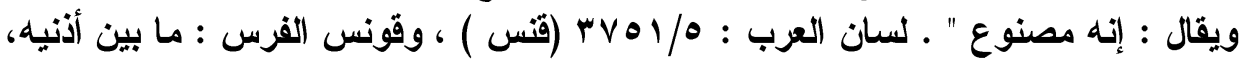

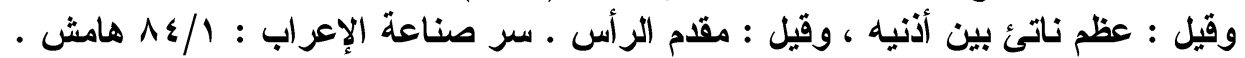

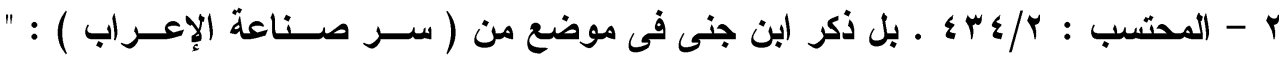

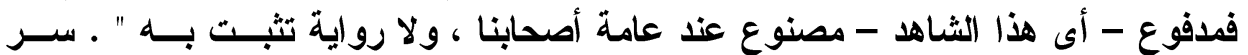

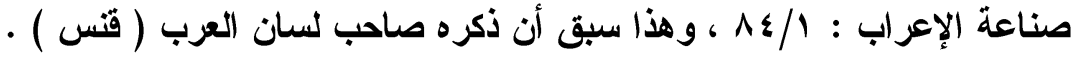

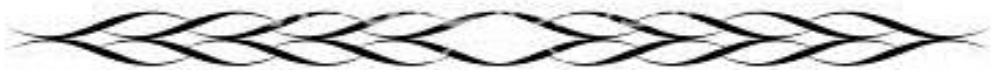




\section{الترقيم الدولخ}

ISSN 2356-9050

هذا ، وقد ساق أبو حيان موقف ابن جنى تماما بشواهده ، غير انـــه نص على أن هذه القزاعة قراعة مرزولة (1)، ولعلها تكافئ عبارة ابن مجاهد السابقة : " وهذا غير جائز أصلا " .

ولألك لم يلرج أبو جعفر هذه القراعة ضمن قراعات الآية ، قـال : " أجزم بلم ، وعلامة الجزم حذف الضمة "(r) .

بل ساق أبو حيان تخريجا للآية ، وصفه بانهـ " أحسن من هذا كلــه " وهو " أنه لغة لبعض العرب ، وحكاها اللحيانى فى نوادره ، وهــى الجـزم بلن، والنصب بلم ، عكس المعروف عند الناس" (").

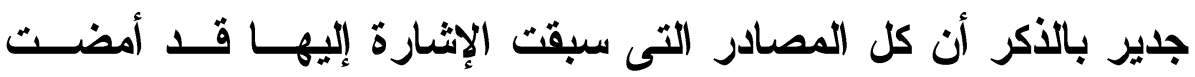

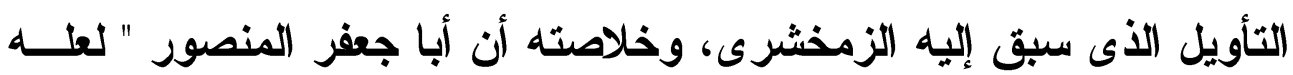
بين الحاء ، وأثبعها فى مخرجها ، فظن السامع أنه فتحها"(؛) فئ. وهو بعيد لأنه تفرد بهذا التأويل أولا ، ولأنه تأويل لا يقوم على أساس

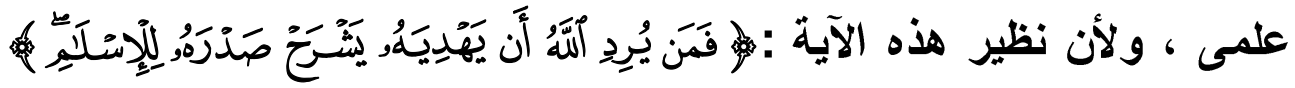
الأنعام: ه إ، فلم تفتح الحاء من (يشرح ) وهى ساكنة كسابقتها . وعليه فلا غرابة فى عبارة ابن مجاهد : " وهذا غير جـائز أصــلا "

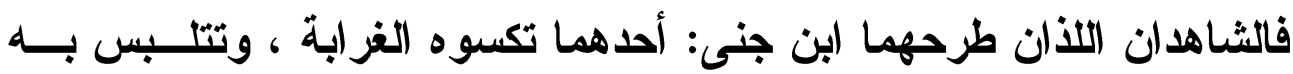
1 - البحر المحيط : ANV/A ـ

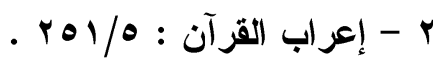

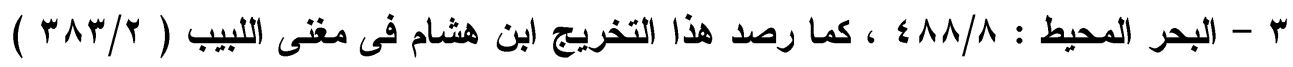

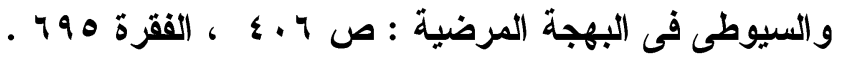




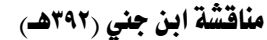

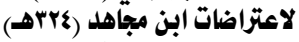

على بعض الروايات في الماحتسب مئ

التصورات غير المألوفة ، وغير المسلم بها عند الكثير ، أما الثانى فمصنوع

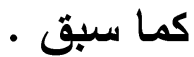

وكما سبق أن ذكرنا بعض النماذج النى تحققت فيها مو (فقة ابن جنــى

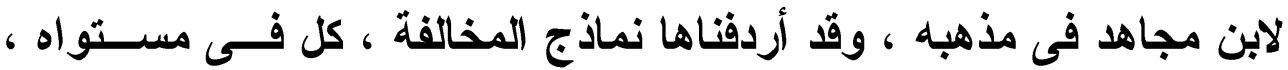

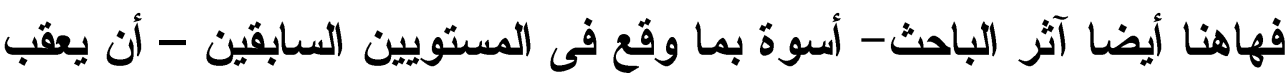

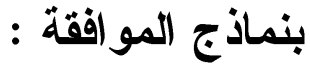

وقد استهللنا نماذج المو افقة بما وقع لآية البقرة من تأويل :

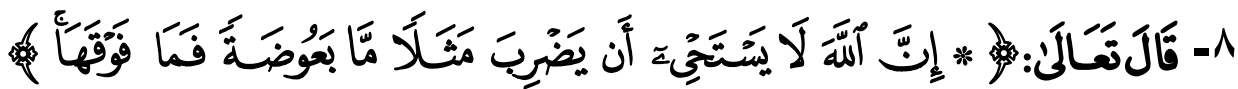

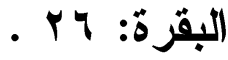

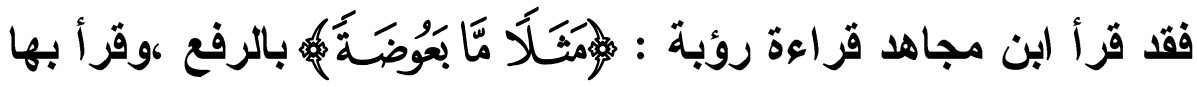
أيضا ابن أبي عبلة والضحاك، واتفقوا على أنها خبر لمبتدأ ،ولكنهم اختلفوا

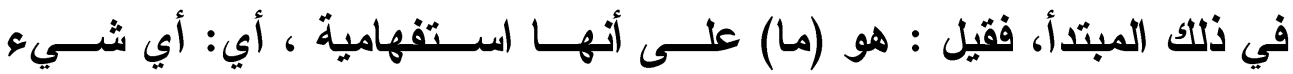
بعوضة، وإليه ذهب الزمخشري ورجحه (1)، وقد و واققه (ابن جنـى قــــائلا :

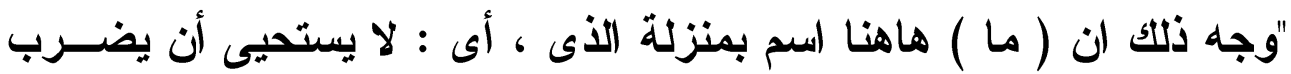

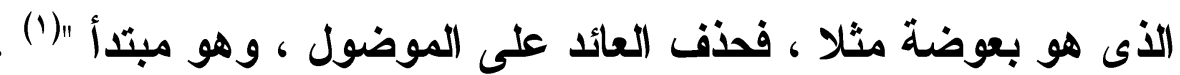

1 - انظر: الار المصون:

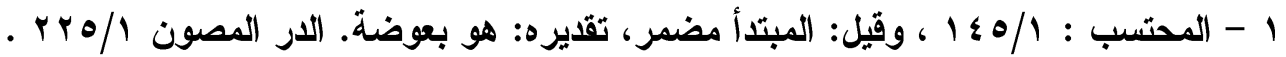
وهذا النص لابن مجاهل غير مدرج في كتاب السبعة. 


\section{الترقير الدولخ}

ISSN 2356-9050
(1) 1 (1.

حولية كلية اللفة العربية بجرجا مجلة علمية محكمة

إذن ، فابن جنى يؤصل لقزاءة رؤبة التى نقلها ابن مجاهد ، وتقديرها

- كما سبق - أن (ما) ها هنا اسم بمنزلة الـــى (')، أى : لا يســتحى أن أن

يضرب الأى هو بعوضة مثلا ، فحذف العائد ، وهو مبتدأ (r).

وهو تأويل وافق فيه ابن جنى مذهب النحاة ، كمــا وافـثق رأى ابـن

مجاهد ، وهذا بعنى ان ابن مجاهد لم يأخذ نفسه فى كل مرة بمعارضة ابـن جنى ، فربما خالفه كثيرا ، وواققه قليلا ، وهذه إحدى المرات التــى وافـث فيها (بن جنى ابن مجاهد .

وباستعراض أقوال النحاة ، فربما اطمأتت النفس إلى ما ذهب إليه (بن

:نى :

ففى شرح التسهيل : " ويمعنى الأى وفروعــه : ( مسـن ) و ( مــا )

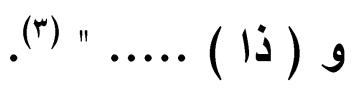

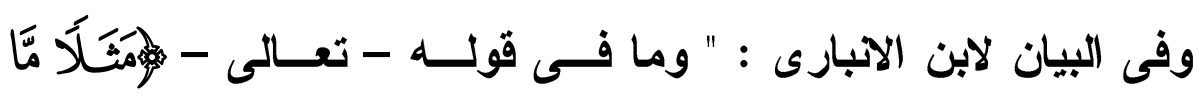

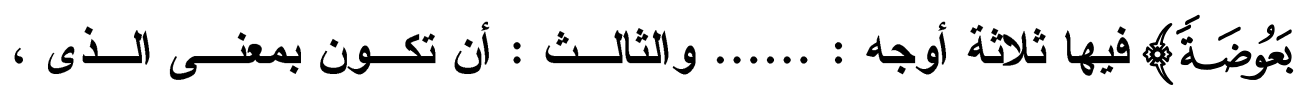
و(بعوضة) مرفوع، لأهل خبر مبتدأ مقدر ، وتقديره: الذى هو بعوضة"(1).

1 - شرح التسهيل : (بن مالكك ، تحقيق : أحمد السيد سيد أحمد على ، دار سعد الدين للطباعة

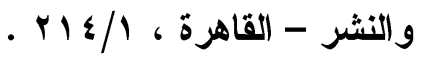

$$
\begin{aligned}
& \text { r - المحتسب : و و }
\end{aligned}
$$

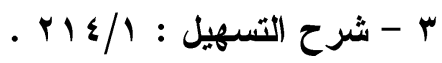

1 - البيان فى غريب إعراب القرآن : ابن الآبارى ، تحقيق : جودة مبروك محمـــ ، مكتبــة

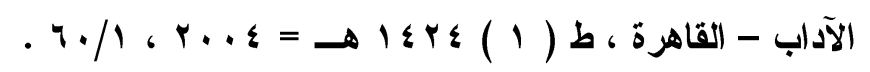

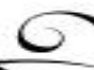


كما استعان ابن الأببارى بنفس الشاهد الأى استعان بــه (بــن جنـى

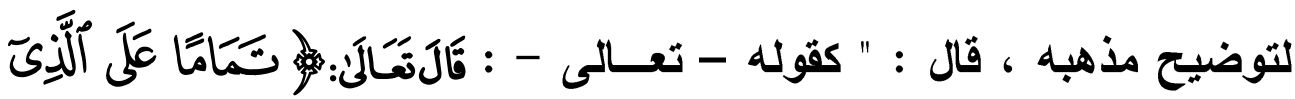

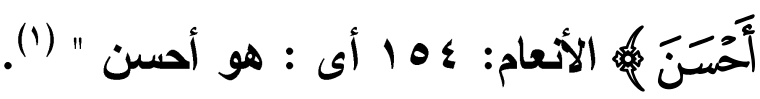
وفى إعر اب القرآن للنحاس : " بعوضة بالرفع ، وهذه لغة تميم جعـل ( ما ) بمعنى الذى ، ورفع بعوضة على إضمار مبتدأ " (r). ومما دعم به ابن جنى موقفه حكاية سيبويه عن الخليل : " مـــا أنــا بالأى قائل للك شيئا . أى : الأى هو قائل لك شيئا " (ب).

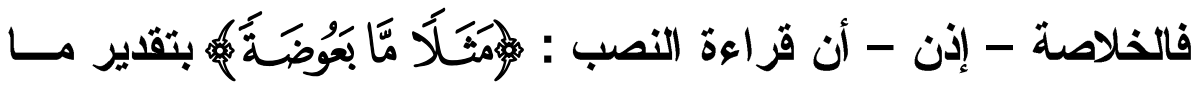
زائدة فى الكلام ، أى : إن الله لا يستحيى أن يضرب بعوضة مــثلا ، أمـــا قراعة الرفع - وهى لهجة تميم - فعلى تقدير أنهم يجعلون (مــا ) بمنزلــة الأى ، ويضمرون ( هو ) كأنهم قالوا : ( لا يستحيى أن يضرب مثلا الـــى

هو بعوضة ) أى : لا يستحيى أن يضرب الأى هو بعوضة مثنلا (\&).

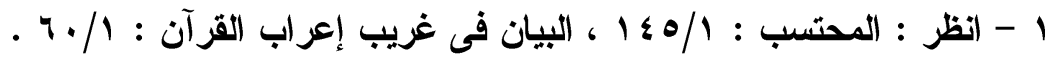

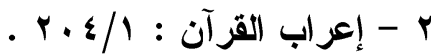

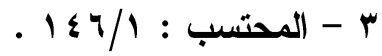

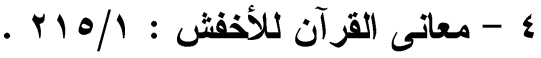




\section{الترقيم الدوله \\ ISSN 2356-9050}

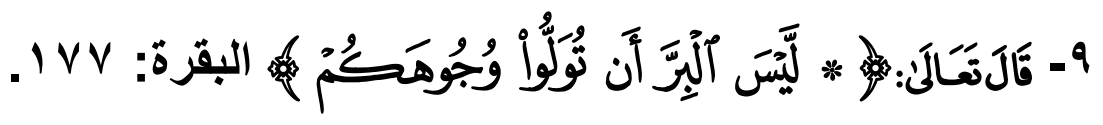

فقد نقل ابن جنى قر اعة أبى وابن مسعود بنصب البر وزيادة البـاء ،

قال ابن مجاهد : " فإذا كان هكذا لم يجز أن ينصب البر " " (1).

وقد وافقه ابن جنى فى أن ما ذهب إليه إنما هو الظاهر ، قــال ابـن

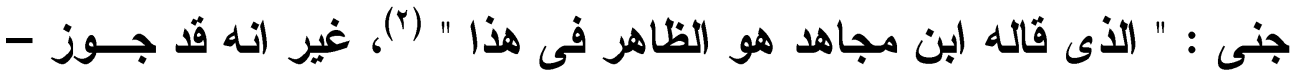

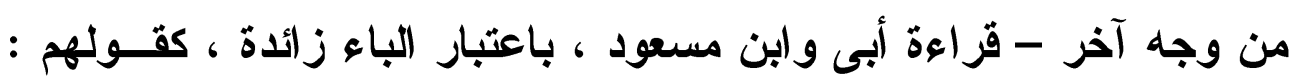

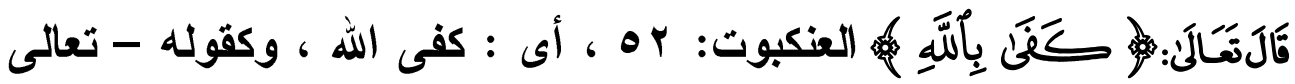
-

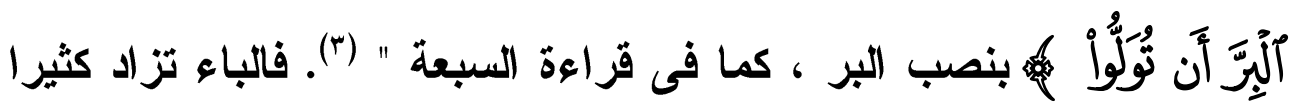
في الخبر بعد ليس، وقد ضرب ابن عقيل المثل بالعديد من الآيات القرآنيــة

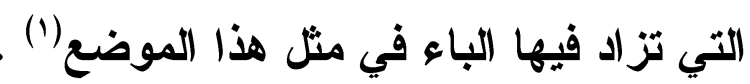

فمن نصب جعل ( أن ) مع صلتها الاسم ، وتقــيرها - عندئــ - :

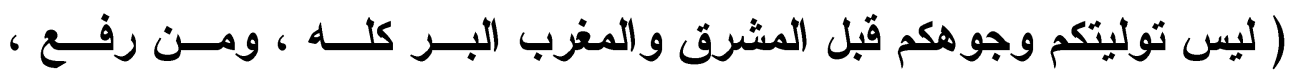
فالمعنى : البر كله توليتكم ، فيكون ( البر ) اسم ليس ، ويكون ( أن تولوا )

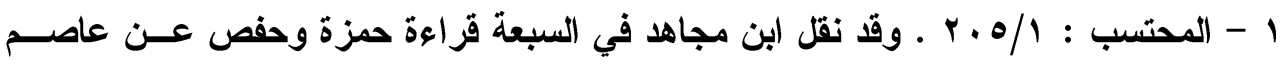
بنصب(البر) ،ورواية هبيرة عن حفص عن عاصم الوجهين بالرفع والنصب. انظر السـبعة

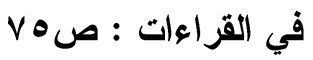

$$
\begin{aligned}
& \text { r }
\end{aligned}
$$

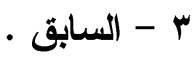

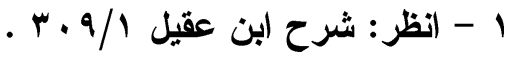


الخبر ، وحجتهم : إدخال الباء على الخبر ، فالباء لا تلخل فى اسم لـيس ،

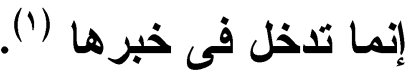

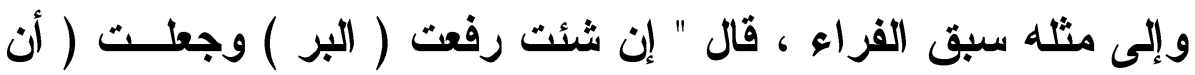

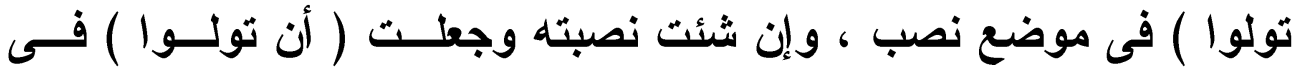

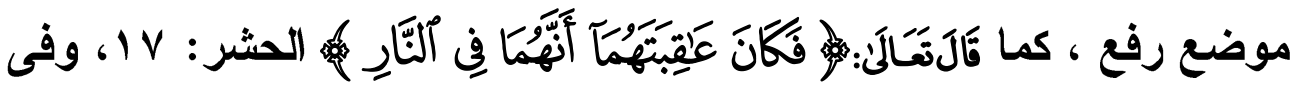
إحدى القراعتين ( ليس البر بأن ) فلذلك اخترنا الرفع فى ( البر ) والمعنــى

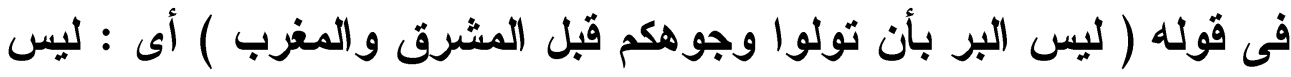
البر كله فى توجهم إلى الصلاة ، واختلاف القبلتين " (؟).

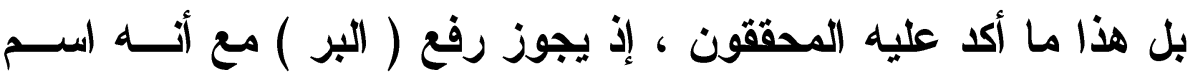

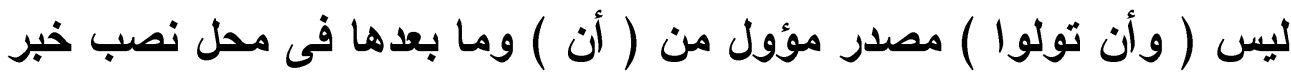

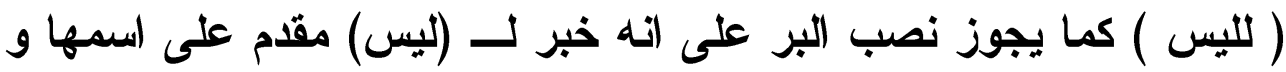

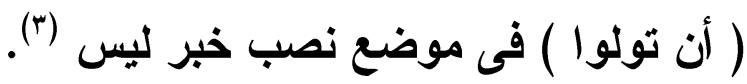
أما آخر نماذج المو (ققة فحول قوله - تعالى : . وهنا أقر ابن جنى قراءة ابن مجاهد عن طلحة بـن سـليمان : ( أن أن

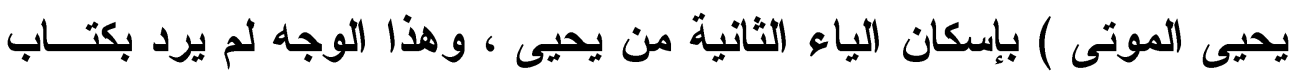

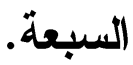

1 - انظر حجة القراءات : (بن زنجلة ، تحقيق : سعيد الأفغانى - مؤسسة الرسالة - بيروت ،

$$
\begin{aligned}
& \text { ط (0) }
\end{aligned}
$$

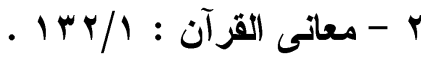

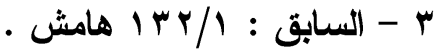

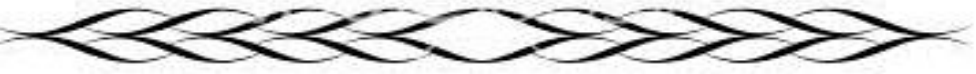


الترقيم الدول\$ ISSN 2356-9050

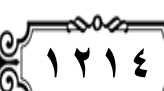

حولية كلية اللفة العربية بجرجا مجلة علمية محكمة الفية

قال ابن جنى : " معنى قول ابن مجاهد : أنه قر أه على سكون اليـاء من ( يحيى ) على لغة من قال : يا دار هند عفت إلا أثافيها(') . فأسكن الياء فى موضع النصب ، لا أن الياء فى قوله ، . يحيى الموتى)

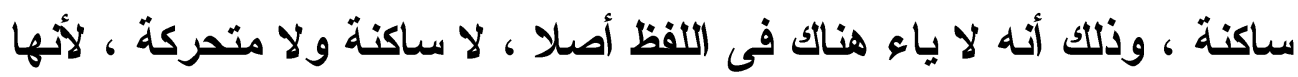

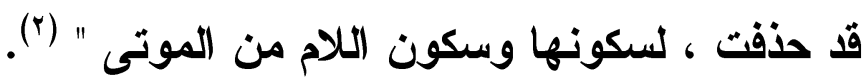

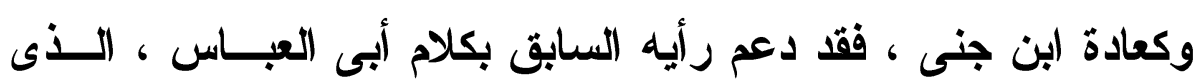

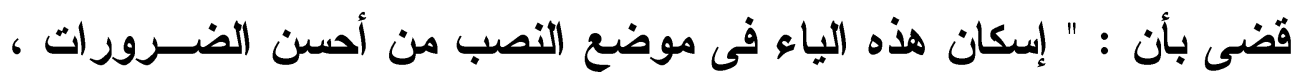

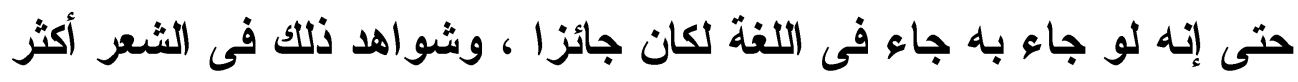

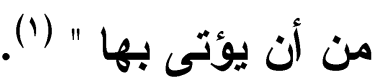
ثم ساق أبو العباس شاهدا فى النثر ، وهو قولهم : ( لا أكلمك حيرى

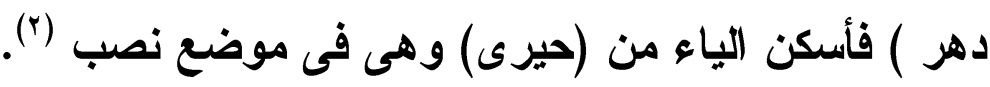

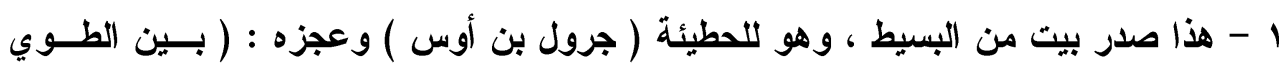

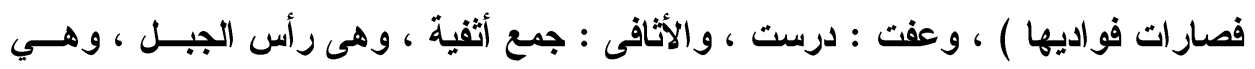

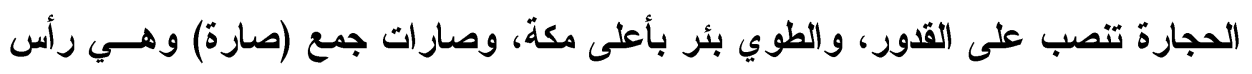

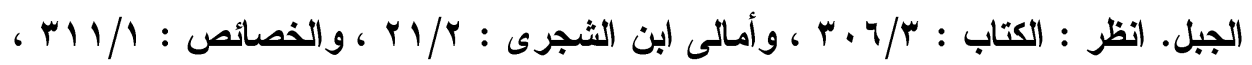

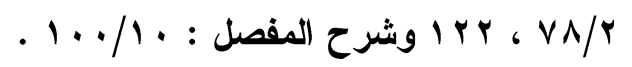

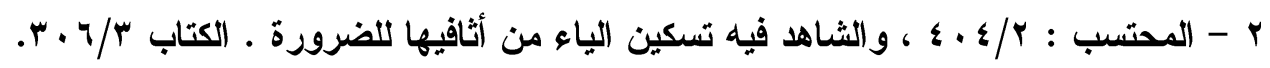

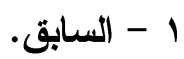

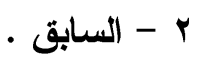

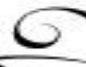




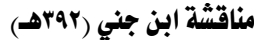

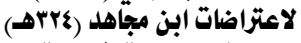

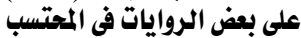

\section{رب هيضل لجب لففت بهيضل (1)}

أراد : رب ، فحذف إحدى الباعين ، وبقى الثانية مجزومة ، كما كاتت قبل الحذف ، وإن لـ يكن هناك موجب للحركة لالتقاء الساكنين ،ولولا ذلـــك لوجب تسكين لام هل وبل ودال ( قد ) إذ لا ساكنين هناك ، فتجب الحركــة

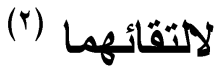

والحقيقة أن ردود الأفعال حول هذه القراعة لم تتسق كلها وفق الإطار الأى رسمه ابن جنى ، فقى الوقت الأى سبق فيه سيبويه إلى هذا المذهب ، محتجا بنفس الثاهد (') بل ومؤصلا لهذا المذهب بقوله : " وإنما اختصـــ هذه الآيات فى هذا الموضع بذا - أى : بالتشكين - لأنهم يجعلون الثــيئين ههنا اسما واحدا فتكون الياء غير حرف الإعراب فيسـكنونها ويشـبـهونها

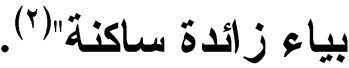

1 - هذا عجز بيت من الكامل لأبى كبير الهزلّى ، وصدره ( أزهير إن يشب القـــال فإنــهـ ) .

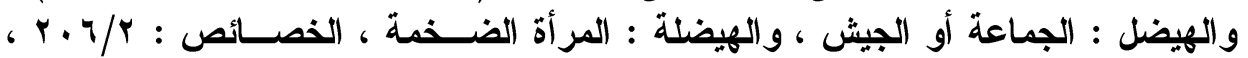

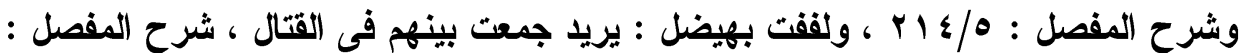

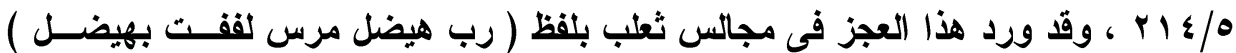

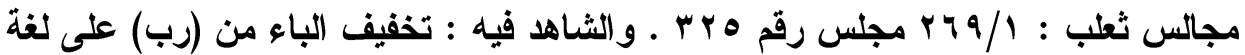

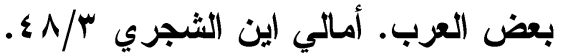

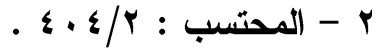
ا 1 - شاهد الحطيئة .

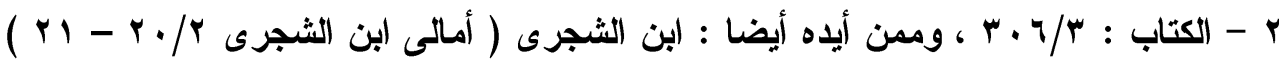

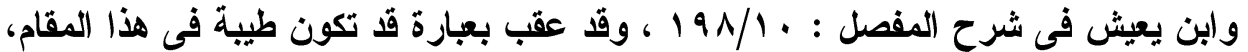

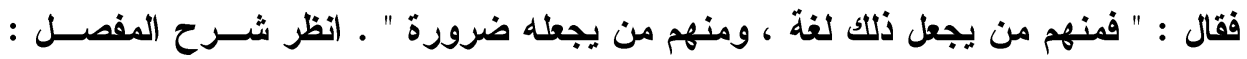

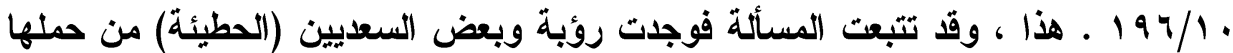

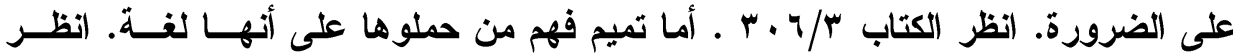

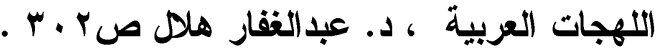

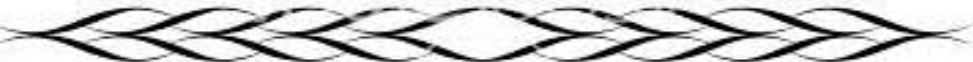


الترقير الدولم ISSN 2356-9050

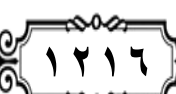

حولية كلية اللفة العربية بجرجا

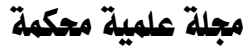

وفى الوقت الأى ذهب فيه سيبويه مذهبه خرج كثير من اللاحقين عن

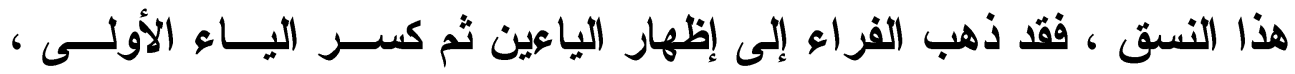

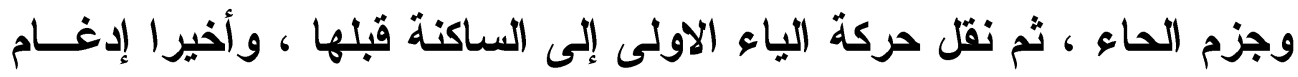
الياء فى الياء ، محتجا بقول الثاعر :

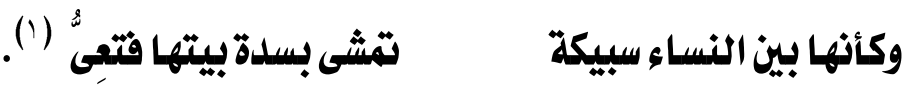

وقد نقل أبو حيان هذه القراعة واستنكرها ، قائلا : " وجاء عن بعضهم

( يحيى ) بنقل حركة الياء إلى الحاء ، و إدغام الياء فى الياء " (1).

كما استنكرها النحاس ، قال : " وهذا خطأ - أى قول الفراء - عنـــ

الخليل وسيبويه ، و العلة فى ذلك - وهو معنى كلام أبى اسحاق - أنــــ إذا فأ

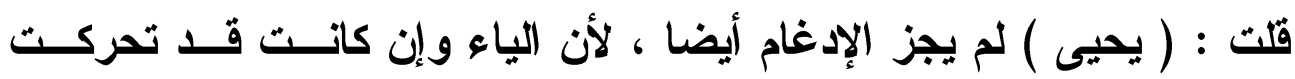

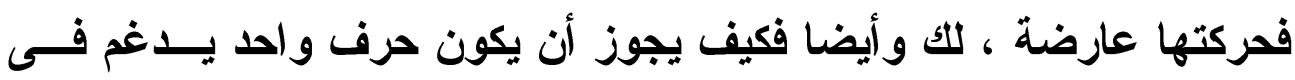

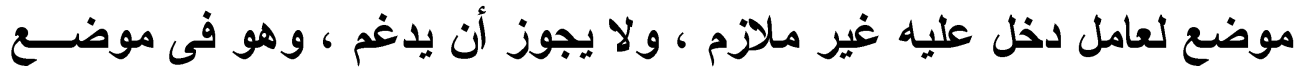

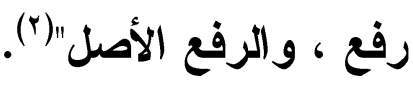

1 - البيت مجهول القائل ،وهو من بحر الكامل، والسبيكة : قطعة مستطيلة من فضة ، وســــ

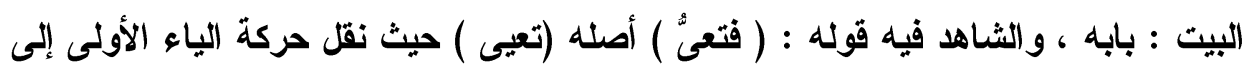

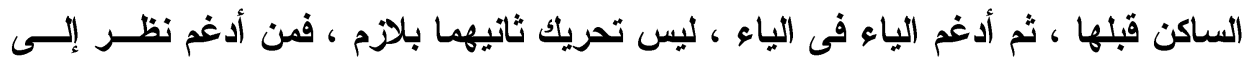

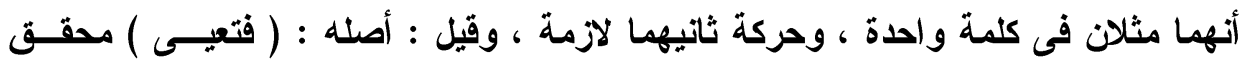

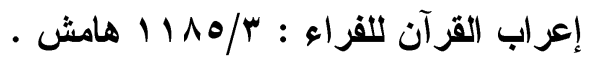

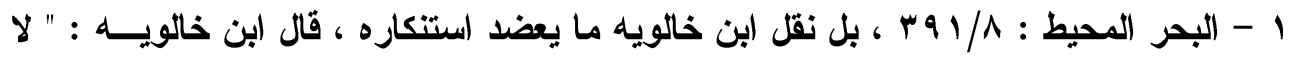

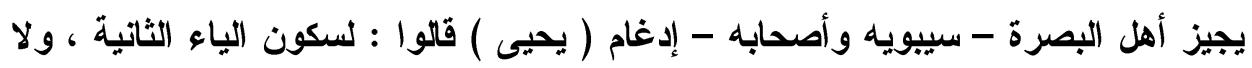

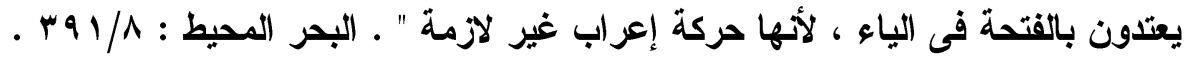

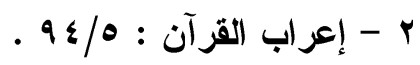


مناقشة ابن جني (rrarهـ)

و الر اجح عندى صحة هذا المذهب ، لثبوت شـــواهده مـن ناحيـة ،

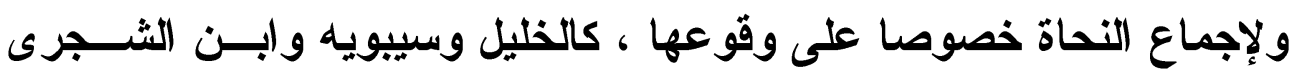

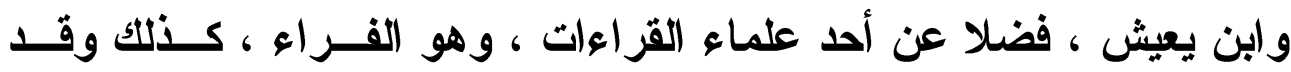

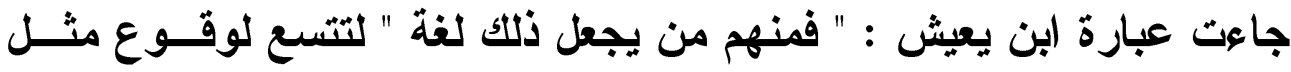
هذه الظواهر ، التى تخرج عن المألوف المعتاد . 


\section{الترقير الدولخ}

ISSN 2356-9050
का 1 ris

حولية كلية اللفة العربية بجرجا مجامية

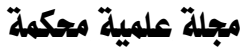

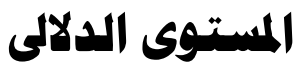

ذللك المستوى الأى يدرس المعنى ، أو ذلك الفرع من فروع علم اللغة

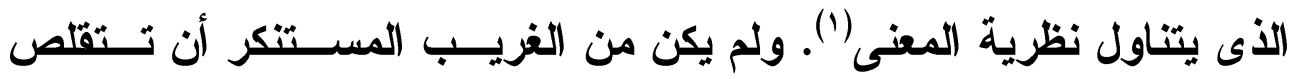
انعكاسات هذا المستوى فى إطار هذا البحث مقارنة بما عكسته المسـتويات

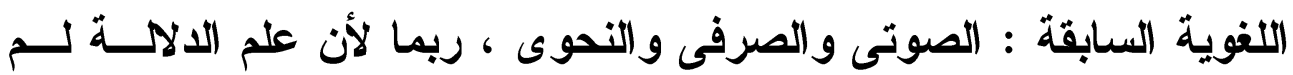

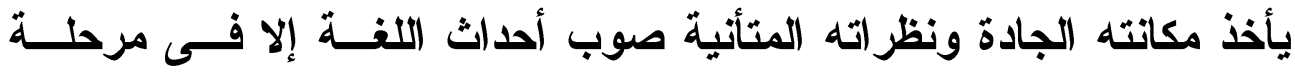

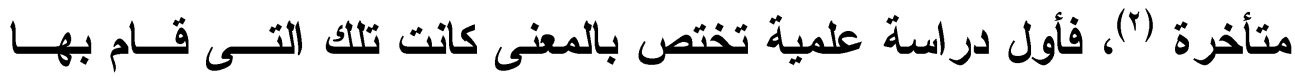

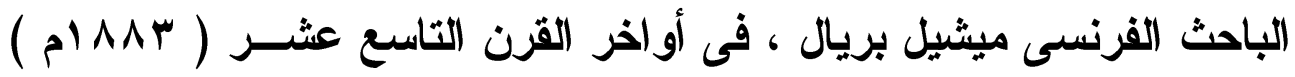

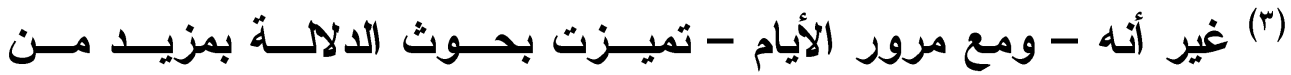

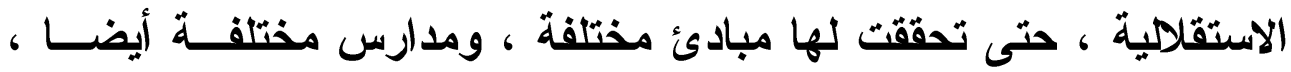
واستطاعت فى عصر يموج بالثقافات أن تكون ملامحها الادقيقة وقضــاياها

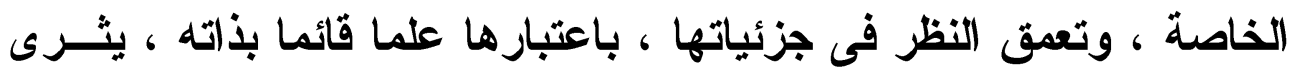
بغيره من رو افد العلم ، ولكنه يتغيا شخصية متميزة المعالم و التقاسيم . ويكمن حصر النماذج التى تنتمى إلى هذا الوجه فيما يلى :

\section{ا - د دلالة الهذف :}

الحذف قد يكون حذفا فى الحركة التى هى بنية الكلمات ، أو للإعراب،

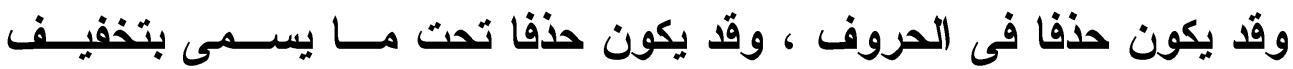

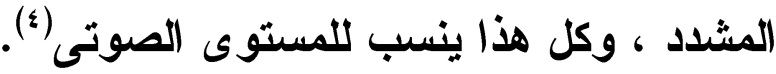

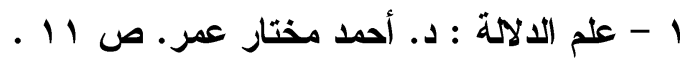

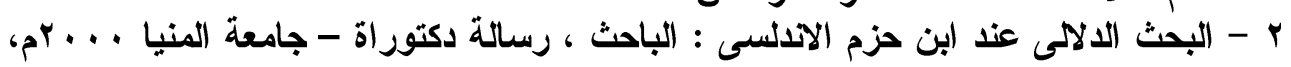

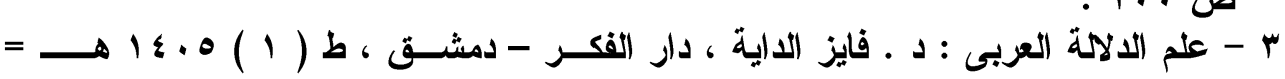

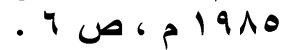

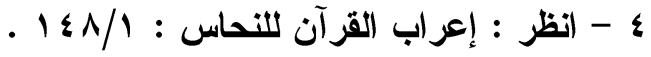




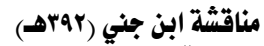

أما الحذف الأى ينتمى إلى المستوى الدلالى ، فإنما هو حــف كلمــة

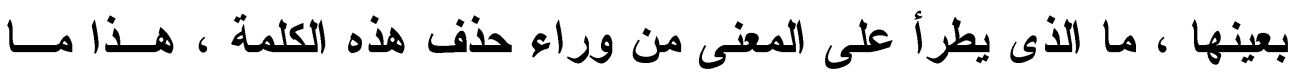
أنتوى رصده فى هذا الإطار • بل ما رصده البحث من وجوه الحذف . وعليه ، فقد وقف البحث عند هذه المسائل :

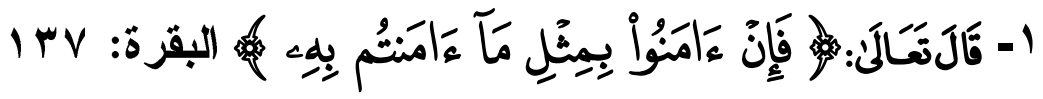
وقد اعترض ابن مجاهد على هذه القراعة ، حاكيا عن ابن عباس أنه

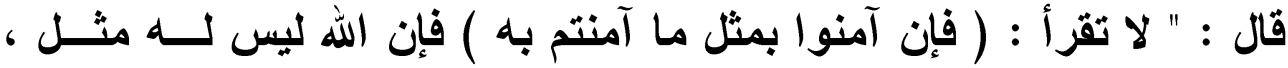
ولكن اقرأ : ( بما آمنتم به ) قال : وروى عنه إنه أيضا أنه كان يقر أ : ( بالذى آمنتم به ) ('). فالخلاف هنا حول كلمة ( مثل ) : هل يجوز حذفها ، وكأنها زائسـة ، أم لا بـ من إدراحها فى السياق؟

أما (بن مجاهد - ووفق رواية ابن عباس - فإنه يرى أنها لا تقــرأ :

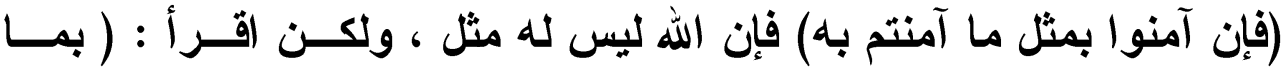

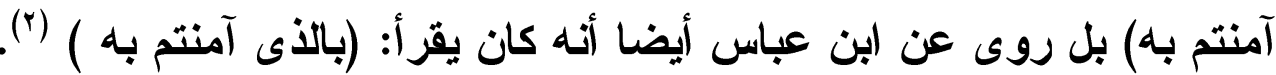
بل نقل أن هذه القزاعة إنما هى قر اعة ابن مسعود (). 


\section{الترقيم الدوله}

ISSN 2356-9050

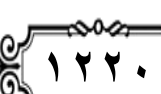

حولية كلية اللفة العربية بجرجا مجية مجلة علمية محكمة

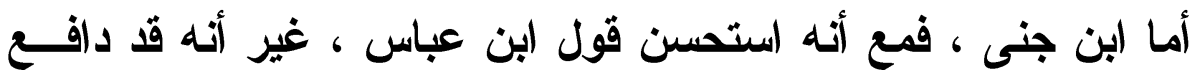

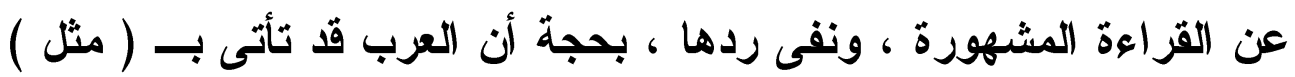
فى نحو هذا توكيدا أو تثديدا .

فالرجل إذا نفى عن نفسه القبيع يقول : مثلى لا يفعل هذا ، أى : أنــا

لا أفعله ، ومثلك إذا سئل أعطى ، أى أنت كذالك (') كما احتج لمذهبه بهذا الرجز :

\section{مثلى لا يحسن قولا فع فع (ץ).}

أى : أنا لا أحننه . وفى حديث سيف بن ذى يزن : " أيها الملك مثثلك

من سر وبر " أى: أنت كذاك ، وهو كثير فى الثعر القديم والمولا جميعا(ث). بل استطرد ابن جنى فى أكثر من مناســبة ، يــلـل بثـــواهد الثـــر

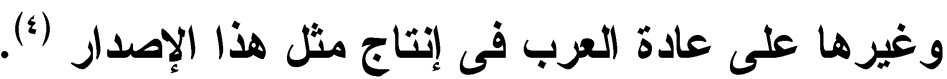
وما ذهب إليه (بن جنى ذهب إليه الزمخشرى ، قال : " هـــا - أى :

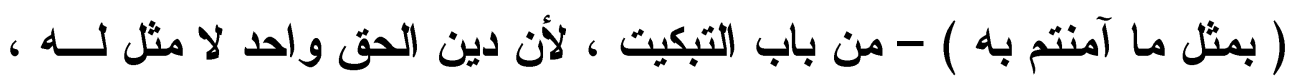

1 - السابق • إذن فـ ( مثل) هنا فيها قولان ، الأول: أنها زائدة ، والتقدير : بما آمنــتم بــه،

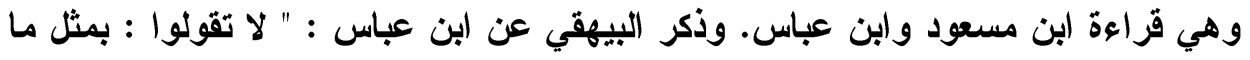

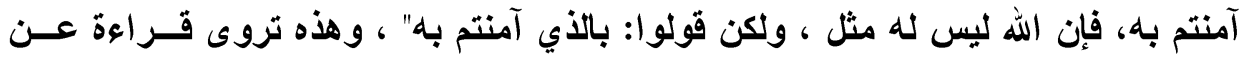

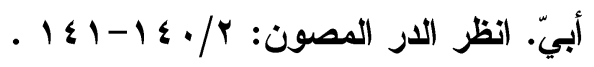

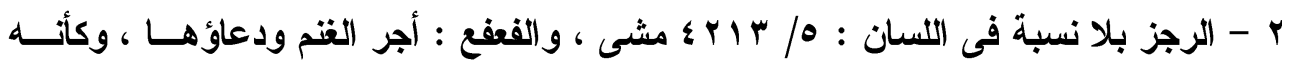

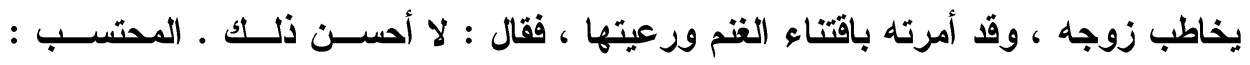

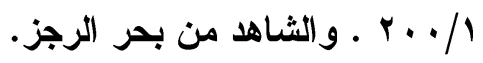

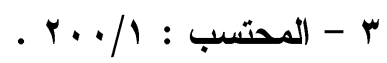
؛ - انظر : الخصائص : : 


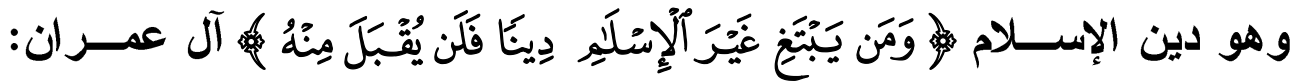

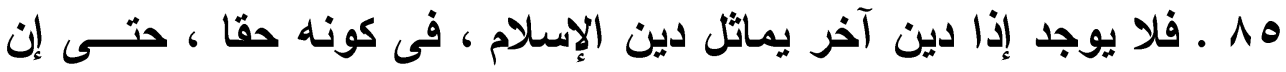

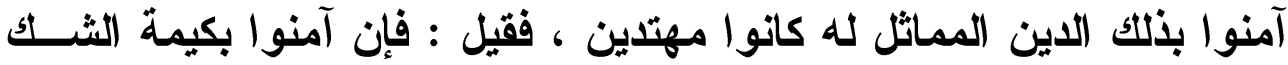
على سبيل الفرض والتقدير، أى : فإن حصلوا دينا آخر مثل دينكم ، مساويا فى الصحة ، فقد اهتدوا (1)

ويمثله أيضا أفتى أبو حيان ، قال " وقالت فرقة : هذا من مجاز الكلام، يقول : هذا أمر لا يفعله مثلكى، أى : لا تفعله أنت ، والمعنى : فــإن آمنـــوا

بالذى آمنتم به، وهذا يؤول إلى إلغاء (مثل) وزيادتها من حيث المعنى"(؟). أما الفخر الرازى فقد واكب - فى عرضه - عرض ابن جنى إلى حــ

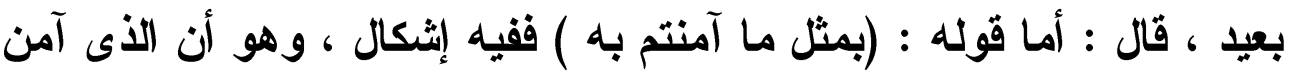
به المؤمنون ليس لله مثل ، وجوابه من وجوه ، أحدها: أن المقصود منــهـ التثبيث ، والمعنى ، إن حصلو ادينا آخر مثل دينكم ، مساويا له فى الصحة

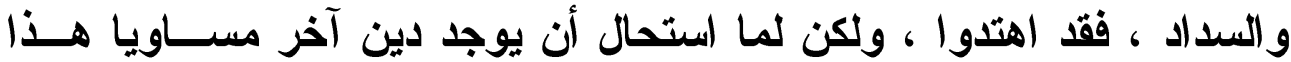
الاين فى السداد ، استحال الاهتداء بغيره ، ونظيره : قولتك للرجـل الــــى

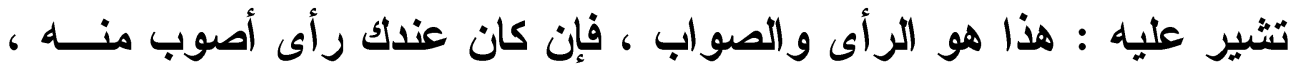

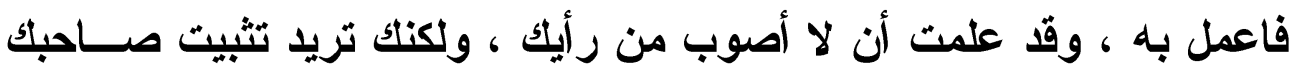

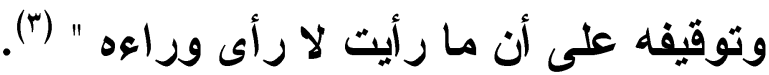

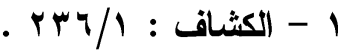
r - البحر المحيط : / / / إ؛ ، ثم ساق أبو حيان - بعد ذلك - رأى الزمخشرى ، وقد سـبقت

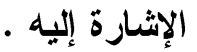

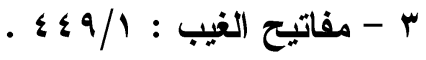




\section{الترقيم الدوله}

ISSN 2356-9050
Q
حولية كلية اللفة العربية بجرجا مجلة علمية محكمة

بل تأمل - إلى أى حد - كيف وافق ابن جنى - فى مذهبه - تقريــر الطبرى عن هذه الآية ، وقد نقل الأخير عن القاضى هذه العبارة : " لا وجه لترك القزاعة المتواترة من حيث يشكل المعنى ويلبس ، لأن ذلك إن جعلــه المر \& مذهبا لزمه أن يغير تلاوة كل الآيات المتشابهات ، وذلك محظور" (1". وقد ذهب ابن الأبارى إلى أن ( مثل ) قد تكون زائدة ، والتقدير عندئذ - ( فإن آمنوا بما آمنتم بـه) محتجا ببعض النظائر القر آنية كقوله - تعالى -

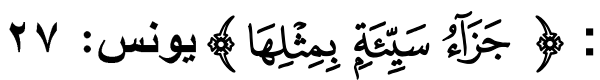

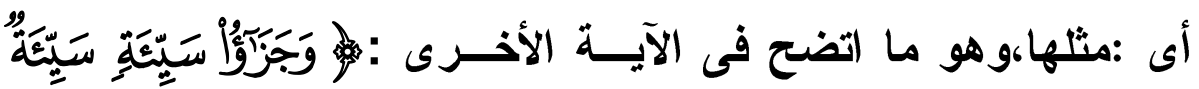

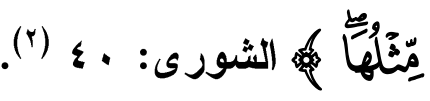

وقد طرح أبو حيان هذا الرأى ثم أعقبه بضده ، قال : " وأما ( مثل ) فقيل : زائدة ، والتقدير: فإن آمنوا بما آمنتم به ،قالوا: كهى فـى قولــه -

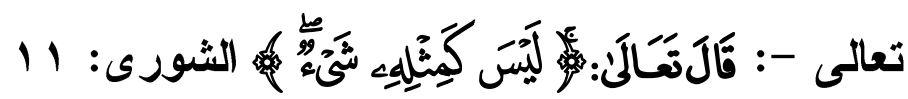
، أى ليس كهو شيء .

1 - السابق ـ ثم عقب الزازى بما يقطع بقناعته بترجيح الوجه الأول ، الأى أثــرت إليـهـ . قائلا : " و الوجه الأول فى الجواب هو المعتمد " . r - البيان فى غريب إعراب القرآن : 19/1 1 .

\section{0}




\section{وكقوله : فصيروا مثل كمصف مأكول (1)}

ثم عقب أبو حيان بنقيض ما ذكره أعلاه ، قائلا : " وقيـلـ : ليســـ

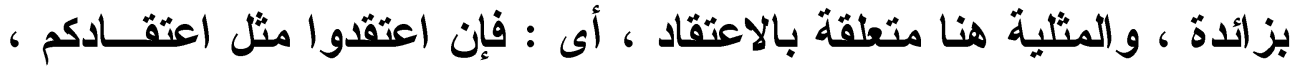
أو متعلقة بالكتاب ، أى : فإن آمنوا بكتاب مثل الكتاب الـــى آمنــتم بــه ، والمعنى : فإن آمنوا بكتابكم المماثل لكتابهم ، أى : فإن آمنوا بالقرآن الأى هو مصدق لما فى التوراة والإجبيل " (r). ولعل هذا ما اجتمعت عليه الأفهام، و ما عكسته عبارة السمين الحلبي التي سبق رصدها (r).

1 - الثـاهد عجز بيت من السريع أورده (بن هشام فى ( أوضــح المســالك ) بــاب الأفعـال

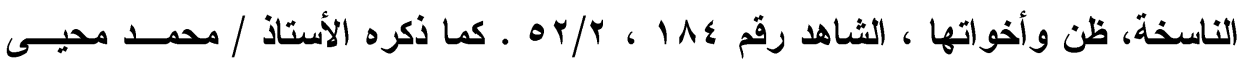
الاين عبدالحميد فى تحقيقه للشاهد اختلاف النحاة فى نسبة البيت ، فمنه من ذكر أنه مسن كلام حميا الأرقط ، وذكر ابن هشام فى - سيرة النبى - صلى الله عليه وسلم - أنه لرؤبة بن العجاج ، وهذا ما رجحه الأستاذ / محمد محيى الاين ، حيث وجد البيــت فـــ ديــوان رؤبة. وهذا الثاهد عجز بيت من السريع ، وصدره : ولعبت طير بهم أبابيل . ـ انظر : البهجة المرضية للسيوطى ، تحقيق : د ـ أحمد إبراهيم محمد على ، مكتبة السنة ـ

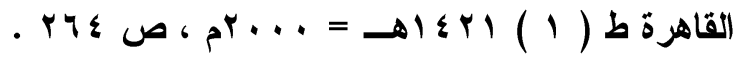

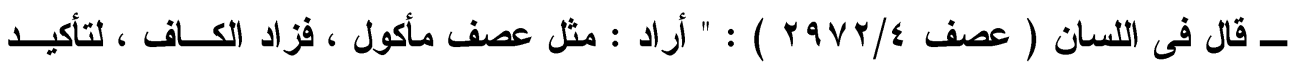

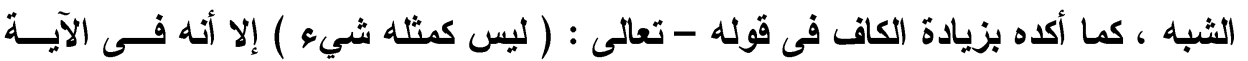

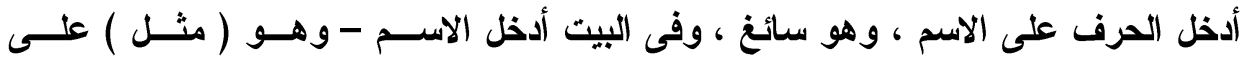
الحرف، وهو الكاف " .

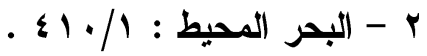

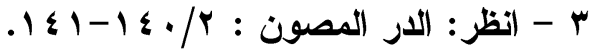




\section{الترقير الدوله \\ ISSN 2356-9050}

\section{r- بلالة الزيادة :}

وفيه وردت بعض القزاعات مشفوعة بزيادة فى ألفاظها يرى ابن جنى

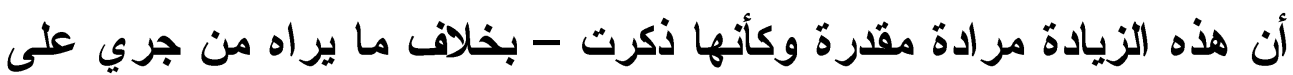

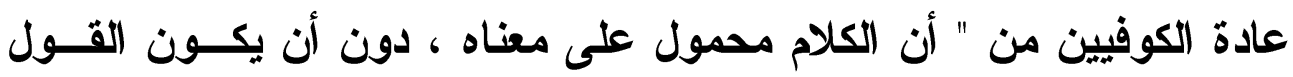

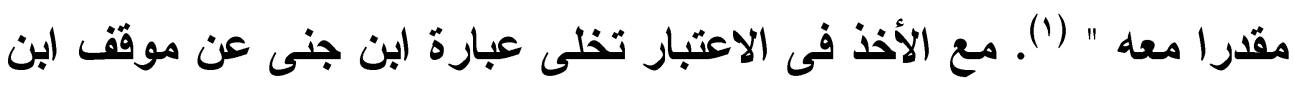
مجاهد من هذه العبارة .

ومما عكس مثل هذا النزاع - وقد أصابه البحث - قوله - تعالى - :

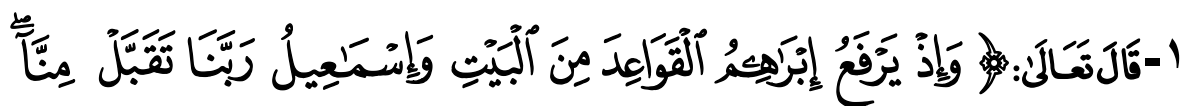

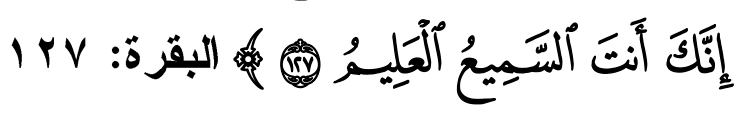

فقد روى ابن مجاهد عن ابن عباس فى مصحف ابن مسـعود : ( و إذ إذ

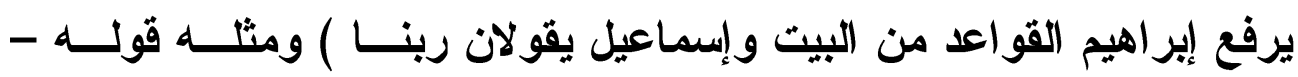

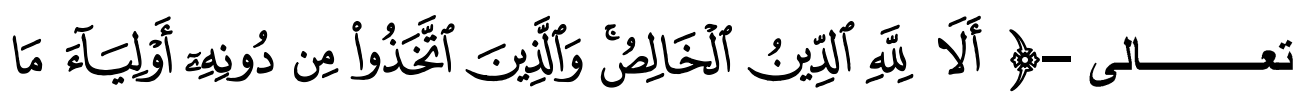

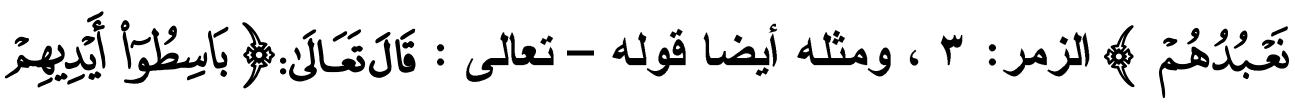

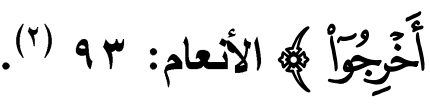

1 - المحتسب : 19 - 19

r - ونظير ما قاله ابن مجاهد قاله السمين العلبي في تعقيبه على هـــا الوجـهـ مـن وجـوه

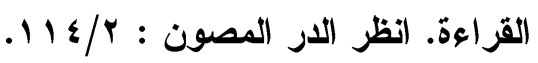


بينما يرى (بن جنى " أن القول هنا مراد مقدر فى نحو هذه الأثشياء ، وأنه ليس كما يذهب إليه الكوفيون من ان الكلام محمول على معنــاه ، دون أن يكون القول مقدرا معه " (1). ثم شرع ابن جنى فى إمطار خصمه بوابل من الثواهد ، على اختلافها ، مدعما ومرجحا ، وذللك كقول الثاعر : لمكاع

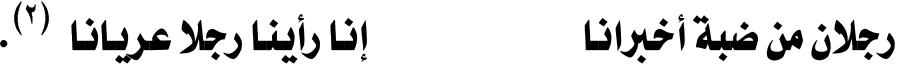

" فهو عندنا نحن - على قالا : إنـا رأينا ، وعلى قـولهم : لا إضــمار

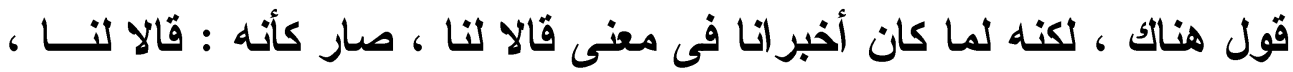

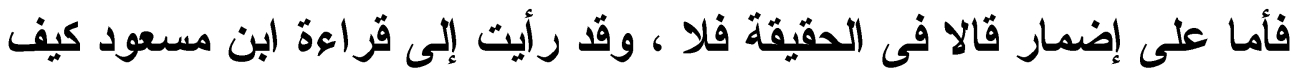

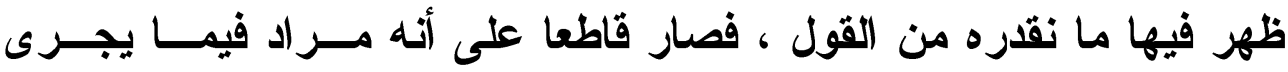

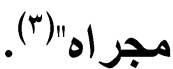

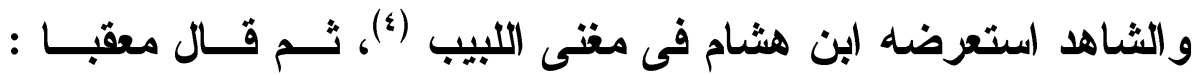

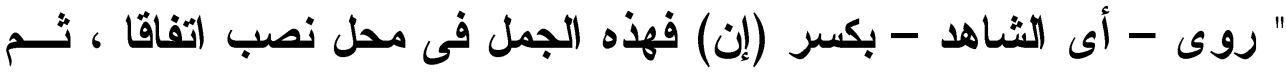
قال البصريون : النصب بقول مقدر ، وقال الكوفيــون: بالفعـل المـــكور ،

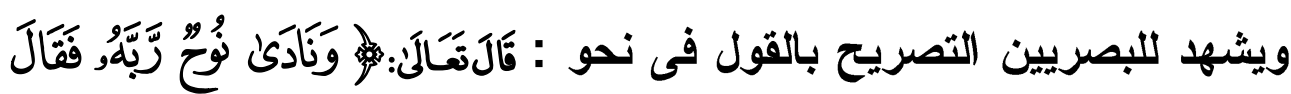

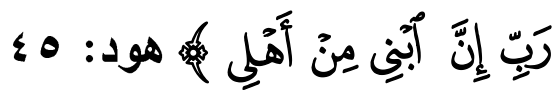

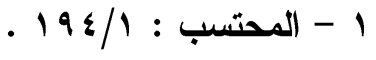

r - الثاهد رواه البذاديون ، وهو بلا نسبة ـ وقا روى في المغنى بلفظ : رجلان من مكسة

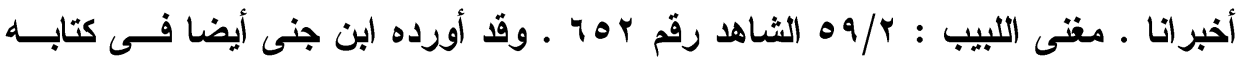

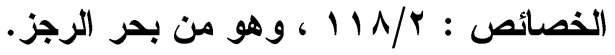

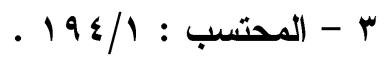

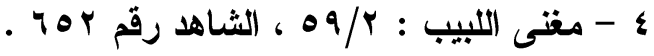




\section{الترقيم الدوله \\ ISSN 2356-9050}

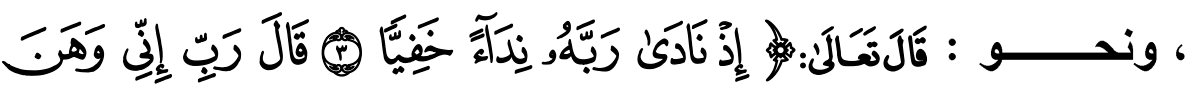

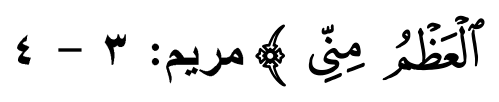

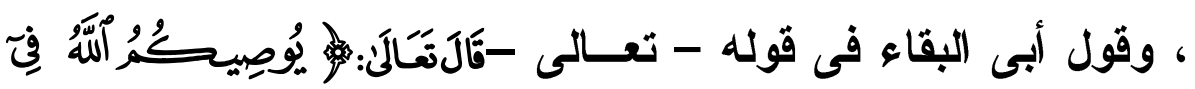

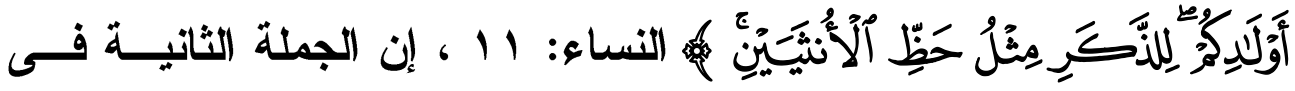

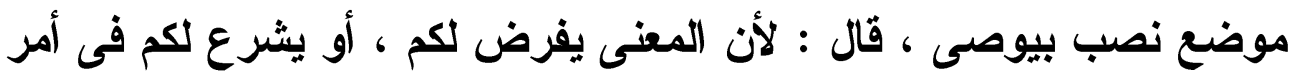
أولادكم ، و إنما يصح هذا على قول الكوفيين " .

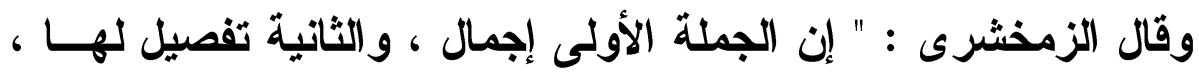

وهذا يقتضى أنه عنده مفسرة ، و ولا محل لها ، وهو الظاهر " (1).

ولذلك قال الفراء - تعقيبا على هذا الثناهد - : " ولو قــال أخبراتسا

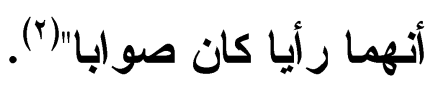

ومما احتج به ابن جنى قول عنترة ، وهو من الكامل :

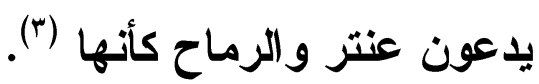

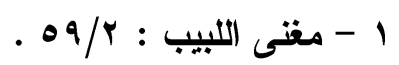

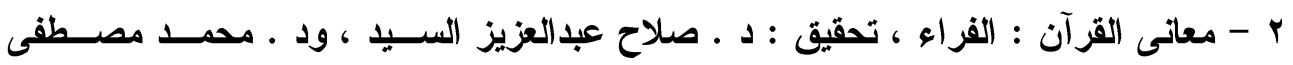

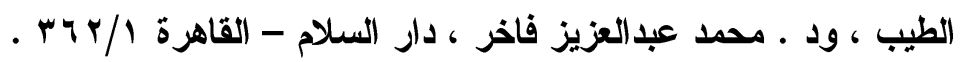

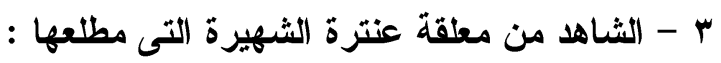
هل غادر الشعراء من متردم أم هل عرفت اللدار بعد توهم

- وعجزه : أثطان بئر فى لبان الأدهم .

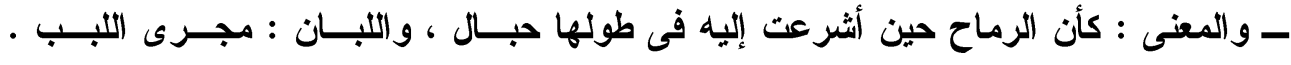

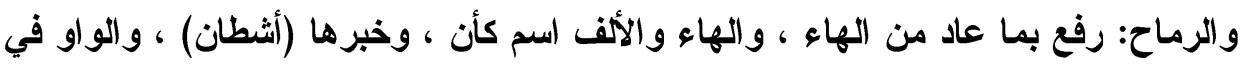

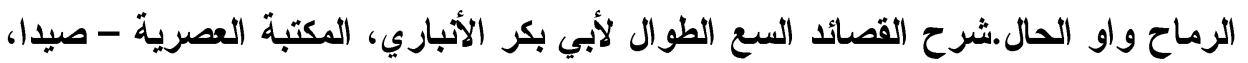

$$
\text { r r الهـr }
$$


فمن ضم الراء من ( عنتر ) أراد : يقولون : يا عنتر ، ومسن فـتح

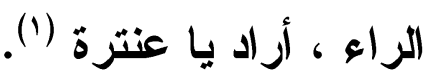

قال ابن هشام : " عنتر بالضم على النداء " (ץ).

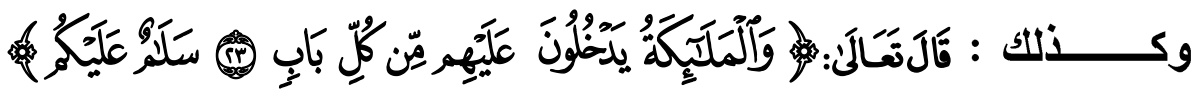

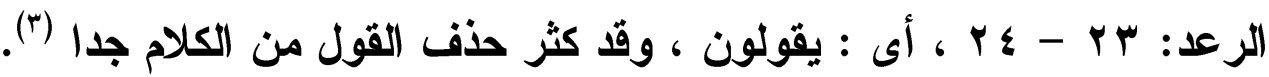

على حين ذهب النحاس - وإن كان قد أقر القراعة - إلى خــلاف مـــ

ذهب إليه ابن جنى ، قال: " و إبماعيل عطف على إبراهيم ، والأى قــال :

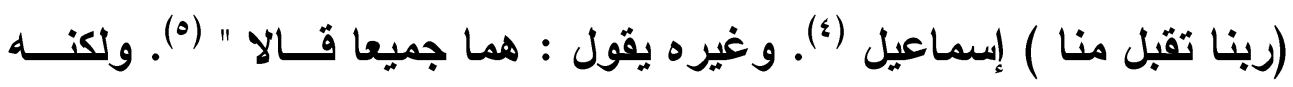

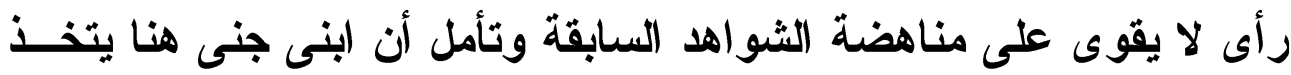
من مذهب ابن مجاهد معبرة لتصويب رأى البصريين ، وهذا يعكس شمولية

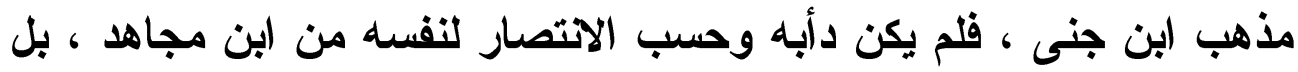

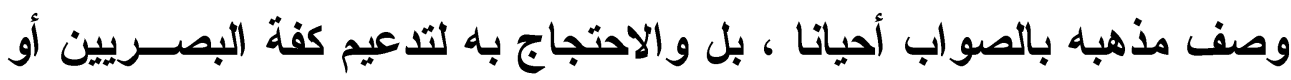

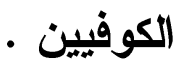

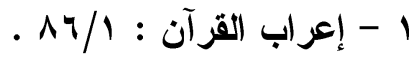

$$
\begin{aligned}
& \text { r - مغنى اللبيب : r / }
\end{aligned}
$$

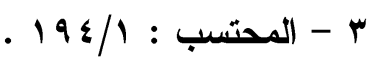

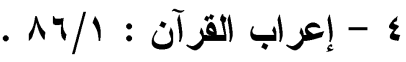

$$
\begin{aligned}
& \text { ه - مغنى اللبيب : }
\end{aligned}
$$




\section{الترقيم الدولم \\ ISSN 2356-9050}

r- العلاقة بين اللفظ والمعنى :

وباعتبار دلالة الألفاظ على المعانى ، فإنه يمكن تقسيم هذه العلاقة إلى

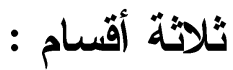

القسم الأول : اختلاف اللفظين لاختلاف المعنيين ، وهذا هو الأصل .

القسم الثانى : اختلاف اللفظين، والمعنى واحد، والمقصود به الترادف .

القسم الثالـث : اتفاق اللفظين ، واخـتلاف المعنــين، والمقصـــود بــه

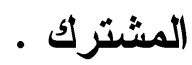

و الحقيقة أن البحث لم يحظ بحالة من حالات الترادف أو المشــترك ،

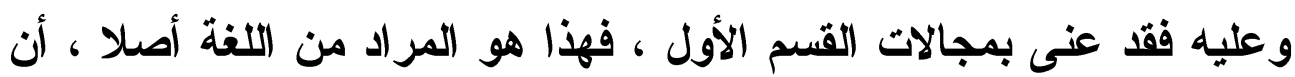

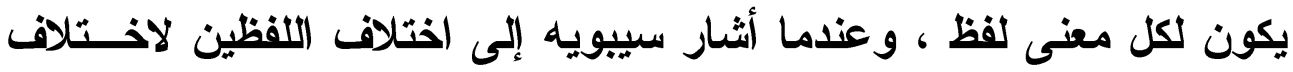

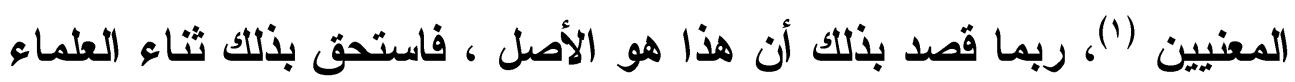

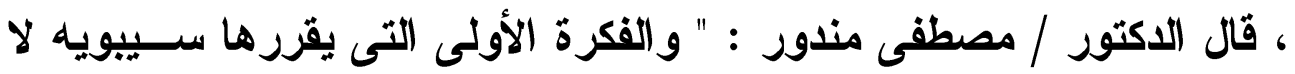

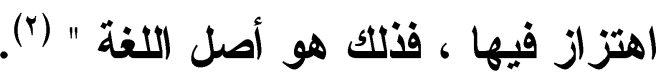

وعليه ، فما أصابه البحث من انتماءات القسم الأول :

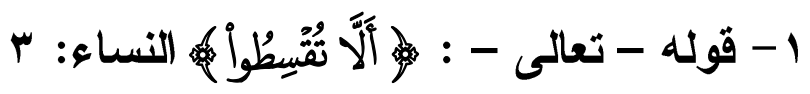

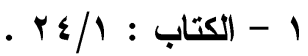

r - اللغة بين العقل و المغامرة : د ـ ـ مصطفى منــدور ، منثــأة المعسارف - الاسـكندرية ، . 10. L 
فقد رواها المفضل عن الأعمش عن يحيى وإبراهيم وأصــحابه : (ألا

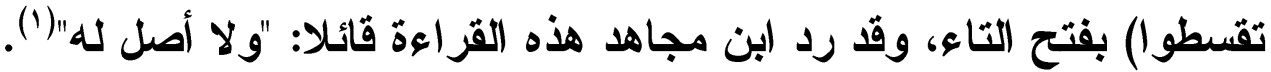
قال ابن جنى : " هذا الأى انكره ابن مجاهد مستقيم غير منكر ، وذلك

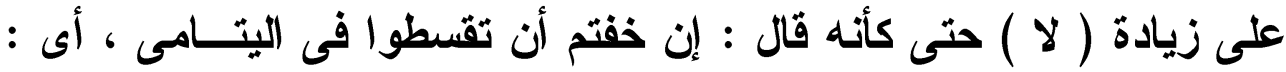
تجوروا ، فيقال قسط إذا جار ، وأقسط إذا عدل ، قال الله - جل وعـلا - :

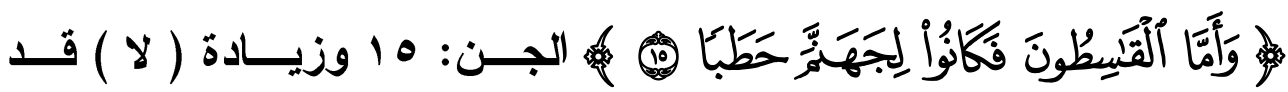

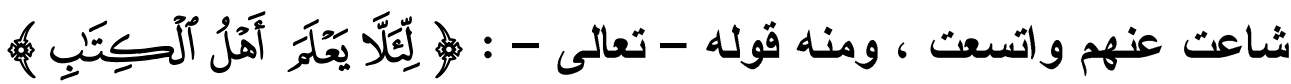

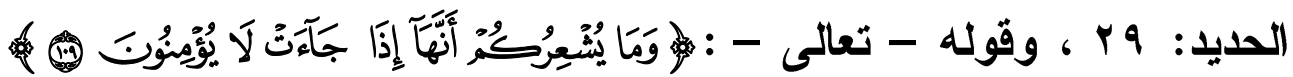

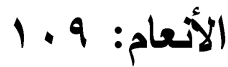

، فمن ذهب إلى زيادة ( لا ) وقال : معناه وما يشعركم أنها إذا جاعت

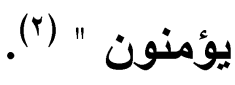

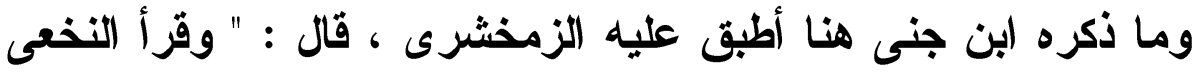

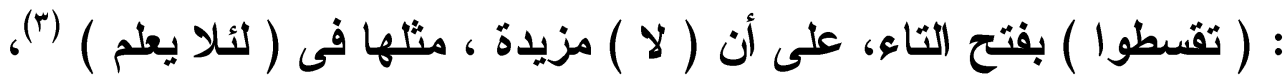

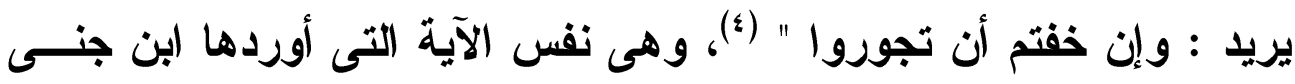

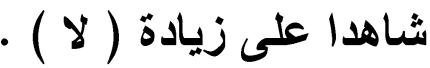
بل ما ذهب إليه أبو حيان أيضا ، قال : " وقرأ النخعى وابـن وثـــاب

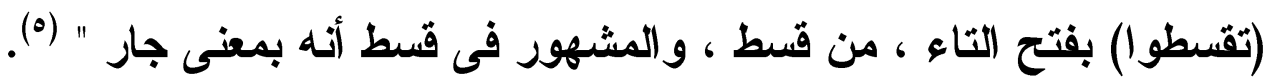

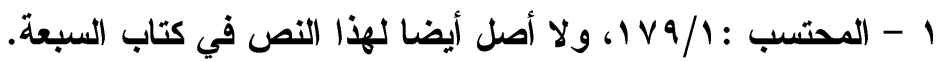

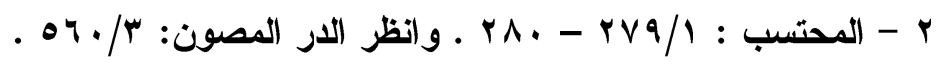

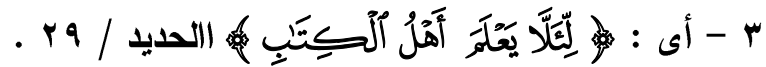

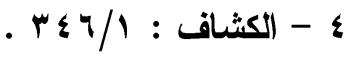

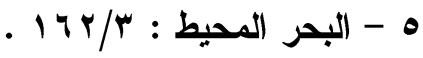




\section{الترقيم الدولخ}

ISSN 2356-9050

وقال الزجاج : " ويقال : قسط بمعنى جار ، وأقسط بمعنى عدل ، فإن

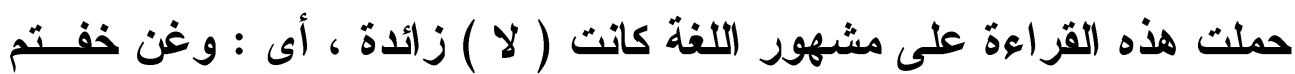

أن تقسطوا ، أى : تجوروا لان المعنى لا يتم إلا باعتقاد زيادتها " (1).

كما أكد الأخفش على المعنى المعجمى الأى طرحه ابــن جنـى فـى

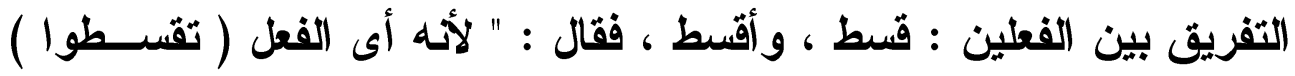

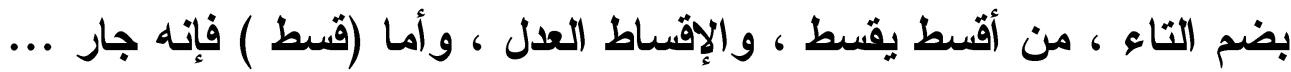

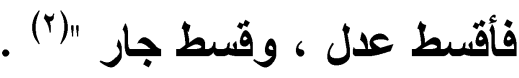

فالخلاصة - إذن - أن قسط بمغى جار ، وأقسط بمغنى أعدل ، و( لا) زائدة ، لان المعنى لا يستقيم إلا بزيادتها ـ

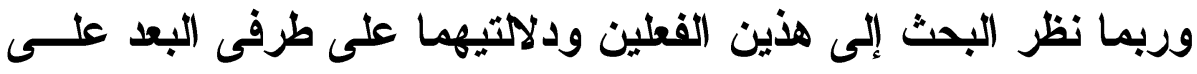

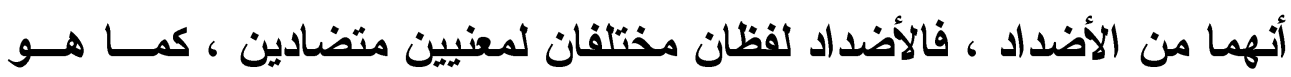
دارج عند علماء اللغة المحدثين :

Two forms with opposite meaning are called Antonyms ${ }^{(3)}$.

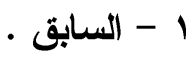

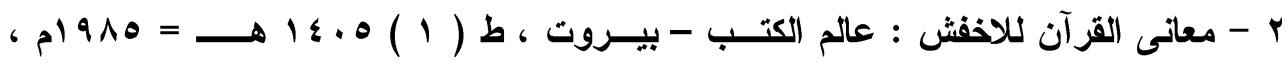

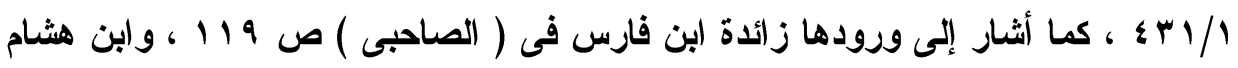

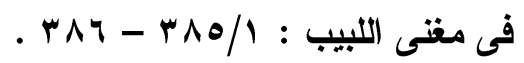

3 - The study of language an introduction ; J . Yule , combridge university press , britian , 1987 , p 95

وترجمة العبارة: كل لفظين يحملان معنيين متضادين يعرفان بالأضداد

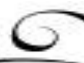


بل وينتميان إلى قسم الأضداد المتدرجة ، وهى الأضداد التــى يمكــن

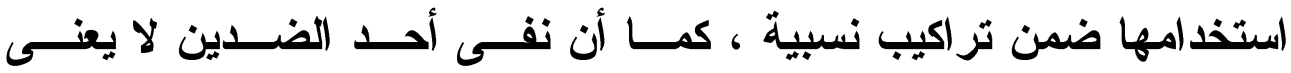

بالضرورة اشتمال الآخر (1).

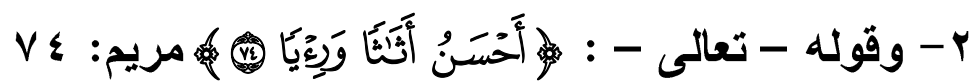
وقد تمخض عن هذه الآية عدة قراعات :

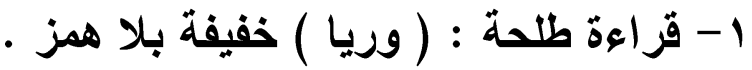
r- قراعة سعيد بن جبير : ( وزيا ) بالزاى • ب- قراعة أبى عمرو : ( سجج) بالهمز . ع - قراعة أهل الكوفة : ( وريا ) مشددة بلا همز • مثرك ه- قر اعة اليزيلى : ( ورياء ) بياء بعدها ألف بعدها همزة ، وقد نقلها أبو • حيان

ونظرا لأن معيار التفريق الأول فى ألفاظ هذه القــراعات إنمـــا هــى الأصوات فآثرت - لهذه العلة - رصدها فى المستوى الصوتى ـ ثم رأيت أن قراهة سعيد بن جبير ( وزيا ) بالزاى تخالف فى مبناهــا ومعناهــا ســائر القراعات ، فرأيت - إتماما للفائدة - رصدها هنا فى المستوى الالالى ، فهى من الزى ، بالزاى ، فعل من ( زويت ) وذلك أنه لا يقال لمن له شيء واحد من آلته : زى ، حتى تكثر آلته المستحسنة ، فهى إذن مــن زويسـث أى :

جمعت (r) (r)

1- The study of language: p.95 .

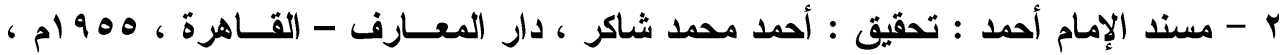

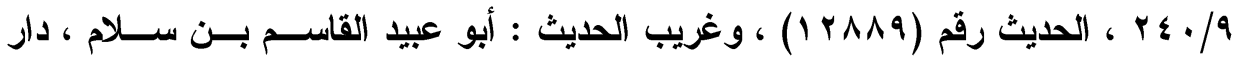

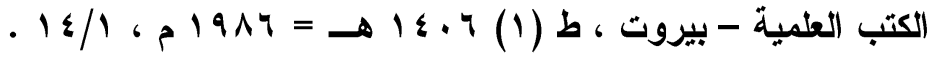

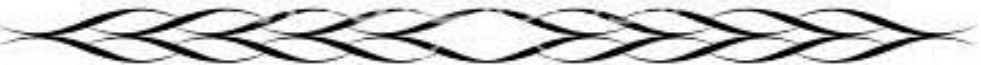




\section{الترقير الدولخ}

ISSN 2356-9050
Q

Larrate
حولية كلية اللفة العربية بجرجا مجلة علمية محكمة

$$
\begin{aligned}
& \text { ومن قول النبى - صلى الله عليه وسلم - : } \\
& \text { " زويث لحى الأرض " (') } \\
& \text { ومن قول الأعشى : }
\end{aligned}
$$

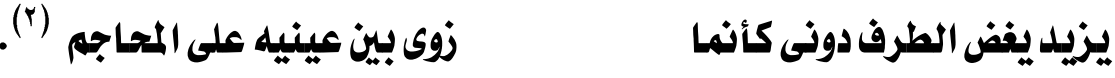

وقد أثنار إلى ما أثنار إليه ابن جنى - فيما يتعلق بهذه القـــراءة - :

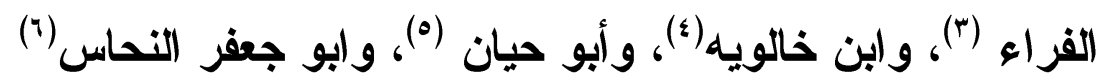

إذن فحصلة القراعات خمس قراعات ، أصاب منها (بن مجاهد ثُلاثــة

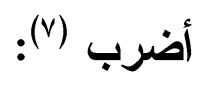

$$
\text { ( ورئيا ) ، ( وريا ) و ( وزيا ) وأقصى اثنتين : }
$$

الأولى : ( وريا ) وهى قراعة طلحة بن مصرف ، بياء واحدة مخففة ، قال عنها أبو جعفر النحاس : " أحسبها غلطا ، وقا زعم بعض النحويين أنه كان أصلها ( ورئيا ) ثم حذفت الهمزة "(^).

1 - النهاية : ابن الأثير ، تحقيق د ـ ـ محمود محمد الطناحى ، المكتبة الإسلامية - القاهرة ط

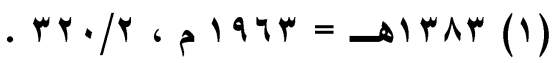

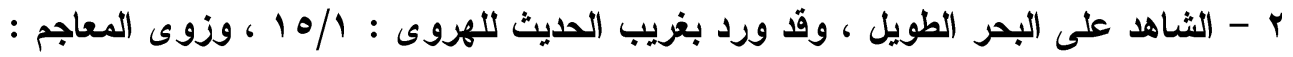

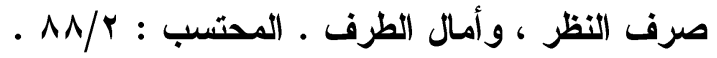

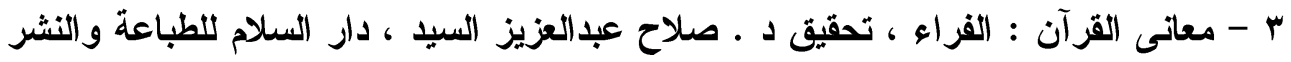

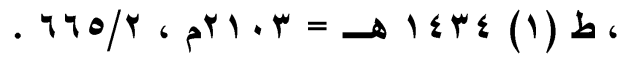

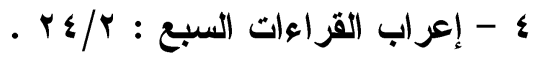

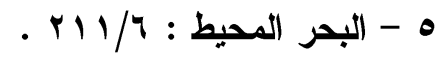

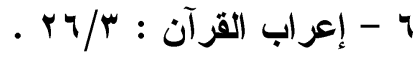

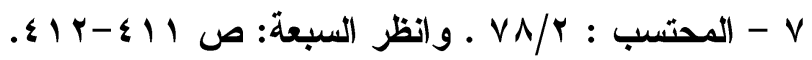

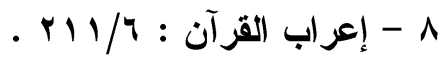


وعليه ، فلا يقدح فى ابن مجاهد أنه أهمل هذه القراية .

والثانية : قراءة اليزيدى ( ورياء ) بياء وبعدها ألف ، بعدها هزة ،

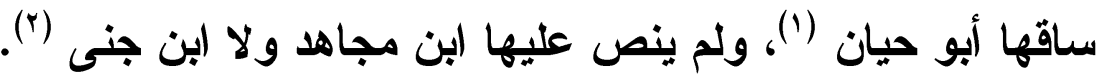

فابن مجاهد نص على ما لا خلاف عليه عند الرواة لا سيما ( وزيا ) .

\section{الخلاصة إذن :}

أن القزاعة الأولى ، قراءة طلحة ( وريا ) قد عرض بهــا النحسـس ،

$$
\text { وردها إلى ( ورئيا ) ثم حذقت الهمزة . }
$$

أم القراعة الثانية : ( وزيا ) سبق تفنيدها ، وطرح أصلها ومدلولها(؟).

أم القراعتان الثالثة والزابعة ، فأصلهما عند ابن جنى من الهمز ، فإذا أريد تخفيف الهمز أبدلت ياء لسكونها وانكسار ما قبلها ، ثم أدغت اليـاء المبدلة من الهمزة فى الياء الثانية ، التى هى لام الفعل فصارت ( وريا ) .

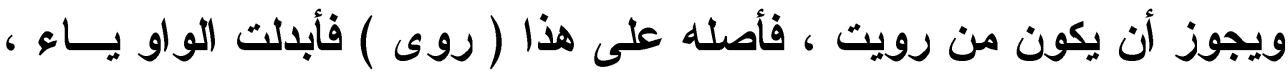

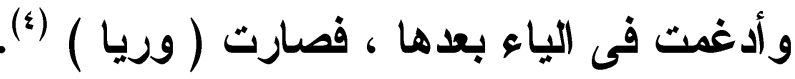

وقد حسن النحاس هذه القراعة ، ووافق (بن جنى فى تأويله ، وفيهــا تقديران : - ت ت

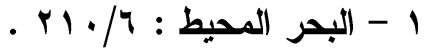

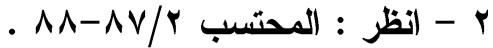

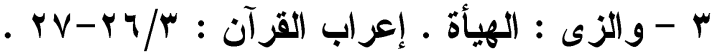

$$
\begin{aligned}
& \text { ؛ - المحتسب : Av/r }
\end{aligned}
$$




\section{الترقيم الدوله \\ ISSN 2356-9050}

أحدهما أن يكون من رأيت ، ثم خفقت الهمزة فأبدل منها ياء وأدغمت

الياء ، وعلى هذا قال ابن عباس : الرى : المنظر ، والمعنى : هم أحسـن أثناثا ولباسا

والوجه الثانى : أن يكون المعنى أن جلودهم مرتوية من النعمة فــلا يجوز الهمز ، لأنه مصدر من رويث ريا (') فالحجة لمن همز : أنه أخـذه هونه

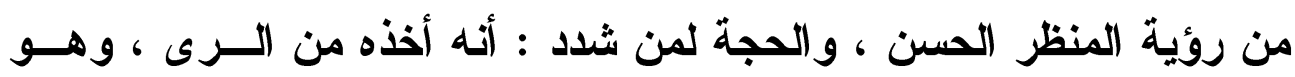
امتلاء الثباب والنضارة وتحير مائه فى الوجه (r). أما القزاعة الخامسة ، فقد حكاها اليزيلدى بياء بعدها ألــف ، بعـدها همزة ( ورياء ) وأصله : (ورئاء ) من المرآة ، أى : يرى بعضهم بعضا

حسنا (r) 
تتبعت هذه الار اسة اعتر اضات ابن مجاهد على ابن جنى فـى كتابــه ( المحتسب ) وما أسفرت عنه هذه المواجهة على مدى مســتويات اللغــة الأربعة : الصوتى ، والصرفى ، والنحوى ، والدلالى ، وقد أسفرت الار اسة عن جملة من النتائج والتوصيات نوجزها فيما يلى : ا - تعقب البحث كل نقاط الخلاف بين ابن جنى وابن مجاهد ، فكانت نقــاط الخلاف على كافة المستويات اللغوية . r - لاحظ البحث قدرا من الموافقة فى الرأى بين ابن جنى وابن مجاهـــ ، وأن هذه المسائل التى تقارب فيها الر أيان لتعد فــى طليعـــة المفــاهيم

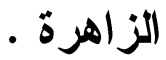

r- كما لاحظ البحث نزاهة العلماء و إنصافهم فى كل مسائل الخــلاف التـى رصدها البحث ، وأن اختلافهم وتواجههم لم يؤثر على أمانة العرض ، والتأصيل للمفاهيم اللغوية .

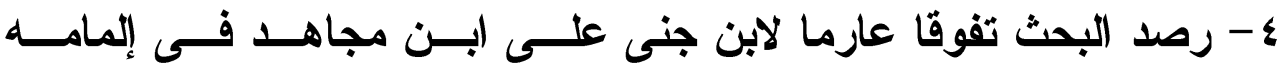
بالقزاءات القرآنية النادرة ، وبروز ابن جنى علما فى هذا الفن ، كمــا رصد لله تفوقا رائعا في التأصيل للظواهر الصــوتية، مــــعما تأصـــيله بوفرة من شواهد اللغة على اختلافها. ه- أثنار البحث إلى مدى مواققة ابن جنى فــى آراعه اللغويــة - لمــذهب اللغويين والنحاة ، الأمر الأى عاد بالسلب على آراء أقر انه. צ- أثنار البحث إلى مدى الأسجام ، الأى أصــاب كـل آراء ابـن جنـى الصوتية على مستوى كل مؤلقاته ، الأمر الأي عاد بــالتقوق والغلبــة

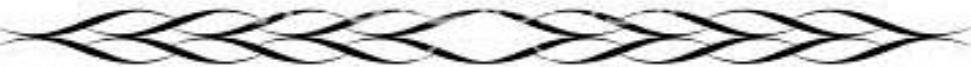




\section{الترقير الدولخ \\ ISSN 2356-9050}

لابن جني في مواجهة ابن مجاهد فيما يتعلـق بالمواجهــات الصــوتية

وكذلك الصرفية.

V- وقف البحث - في بعض الأحيان - عند تندر ابن جني بابن مجاهد تندرا ربما زاد حتى وصل إلى مرتبة التعريض.

1- رصد البحث تفوقا لابن جنى فى المسائل الصرفية ،وكما هو الثأن فى المسائل الصوتية.

9- لاحظ البحث تفوق ابن جنى حتى على مستوى القضــايا المزدوجــة أعنى المسائل التى تخلتهها ظواهر صوتية وصرفية معا - فلم يتلن فيها

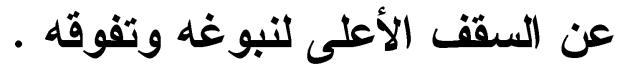
ـ - لاحظ البحث اتساعا شاسعا فى هوة الخلاف بين ابن مجاهد وابن جنى فى معظم القضايا الصرفية بما يتناسب مع ما قيل عن تفوق ابن جنـى الصرفى وما ورد فى السيرة الأتية له ، ففى الوقت الأى يرى فيه ابن مجاهد الامر منكرا ، ير اه ابن جنى مستقيما غير منكر .

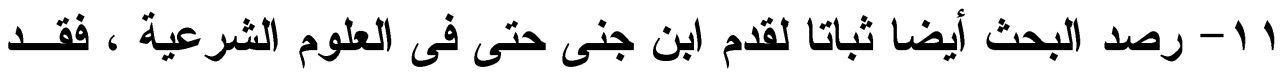
واققت أقواله أقوال المفسرين ، ومذاهبهم ، وغدت مجار اة ابن جنى فى هذه القنون ضربا من ضروب الشقاء والتكلف. r 1 - لاحظ البحث أثارة من حدة وغلظة سادت أقوال ابن جنى فى رده لآراء ابن مجاهد نحو قوله : " هو غلط " وقوله " وهذا قول لا يليق بمن لــه

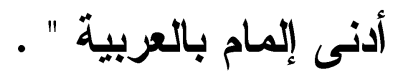

rا - رصد البحث بعض الحالات التى تجاوز فيها الصواب رأى ابن جنى ، كما رصد جملة من المواجهات وافق فيها ابن جنى ابن مجاهد . 


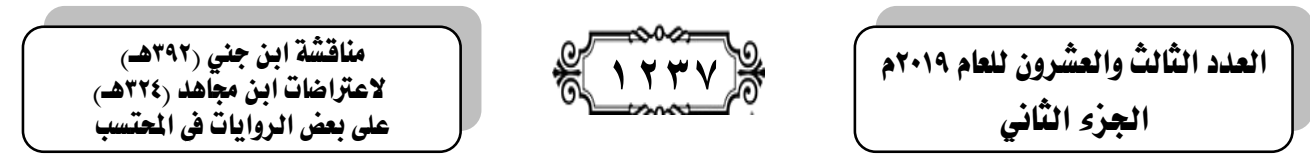

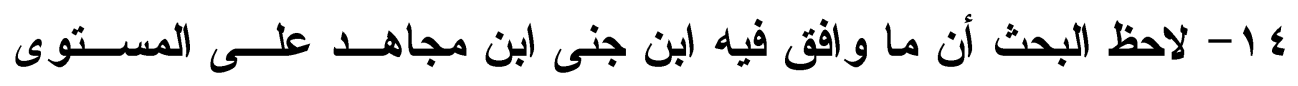

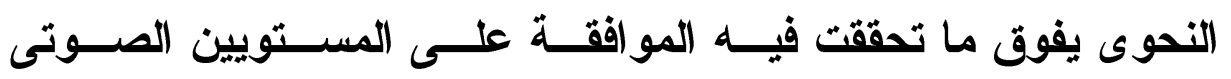

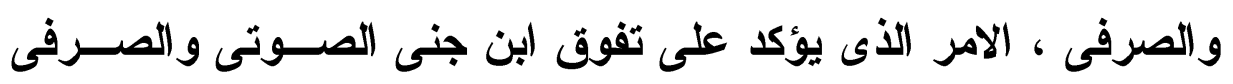

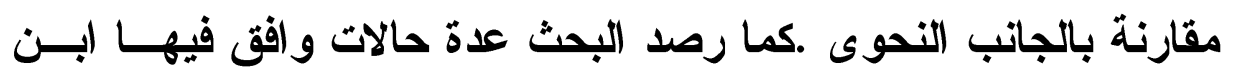

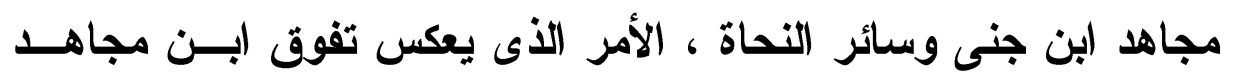

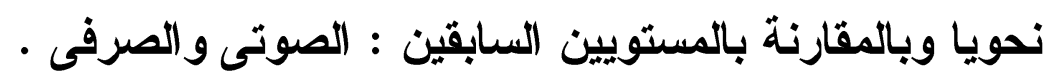
10 - لاحظ البحث تنوع الثواهد التى يدعم بها ابن جنى مذهبه بين القرآن

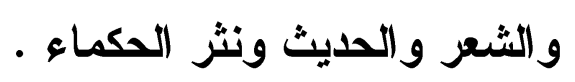
17 - لاحظ البحث تفوق ابن جنى على المستوى الدلالى ، امتدادا لتفوقه فى و

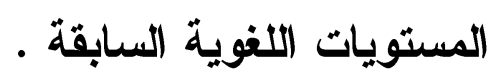
IV

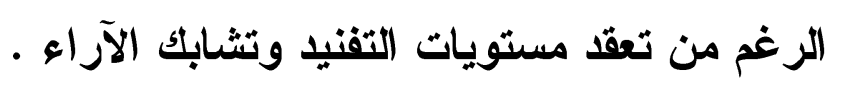

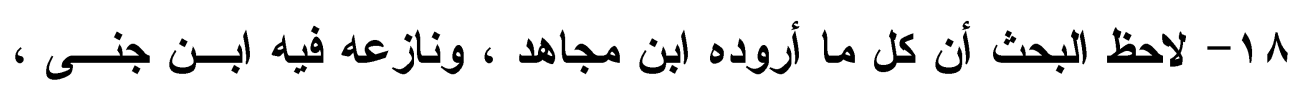

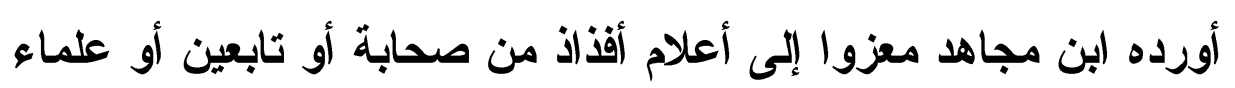
متخصصين فى هذا الفن ، الأمر الذى يخفق من حدة مجانبة ابن مجاهد

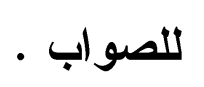

9 ا 19 لاحظ البحث أن ابن جنى لم يكن دأبه وحسب الاتتصار لمذهبه من ابن

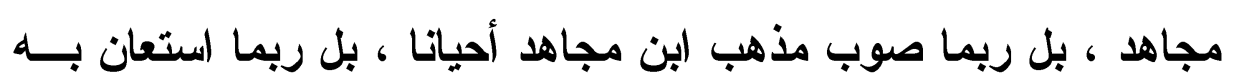

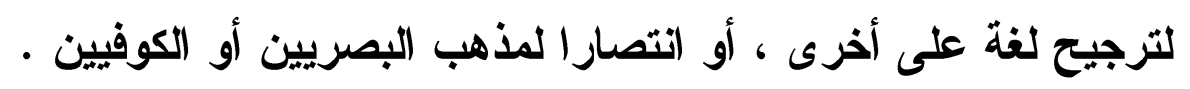

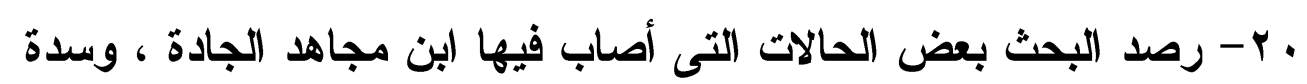
الصواب . الص الب 


\section{الترقيم الدوله \\ ISSN 2356-9050}

\section{الصسادر والمراجع}

( ) (القرآن الكريم : كتاب العزبية ، ومصدرها الأول .

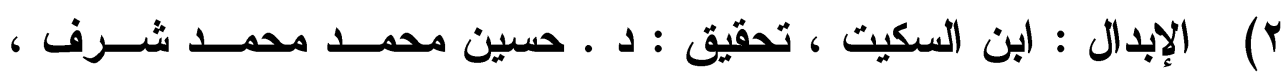
مراجعة : الأستاذ على الجندى ، الهيئة العامة لشئون المطابع الأميرية

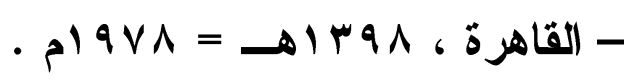

r) أثر الاختلاف في القواعد الأصولية في اختلاف الفقهاء : د ـ مصطفى

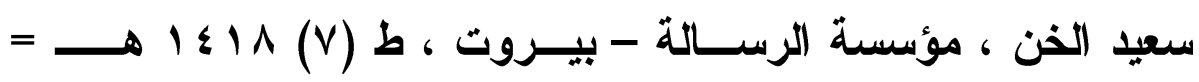
- 1991

أثر اختلاف اللهجات العربية في النحو : د. يحيى على يحيى المباركى

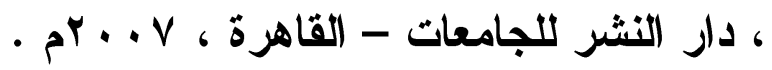

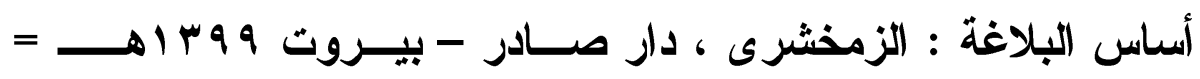
- $19 \vee 9$

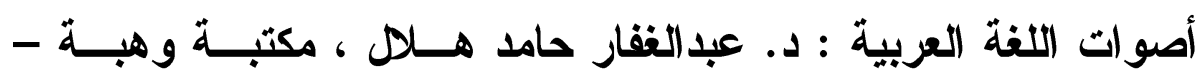

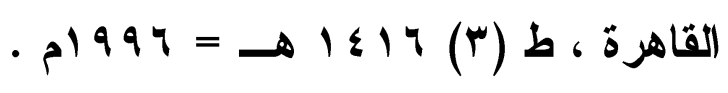

إعراب القرآن : أبو جعفر النحاس ، تحقيق : د. زهير غازى زاهد ،

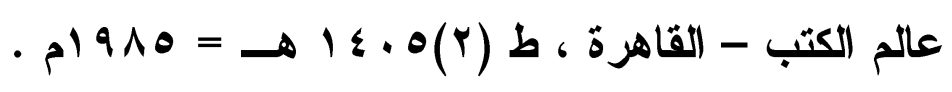

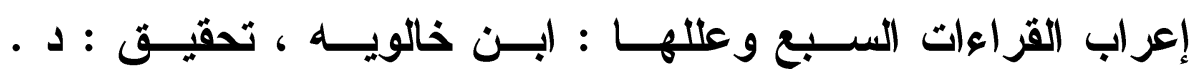

عبدالرحمن بن سليمان العثيمين ، مكتبة الخانجى - القاهرة ، ط (1)

$$
\text { - } 199 r=\rightarrow 1 \leqslant 1 r
$$




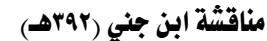

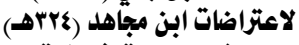

على بعض الروايات في المترتسب فئ

الأفعال : ابن القوطية ، تحقيق : علــى فــودة ، مكتبـــة الخــاتجى -

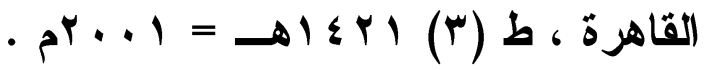

• 1) أمالى (بن الشجرى : تحقيق ودراسة : محمود محمد الطناحى ، مكتبة

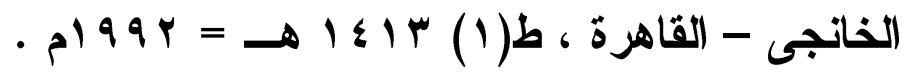

11) أوضح المسالك إلى ألقية (بن مالك : ابن هثام الأصصـارى ، ومعـهـ

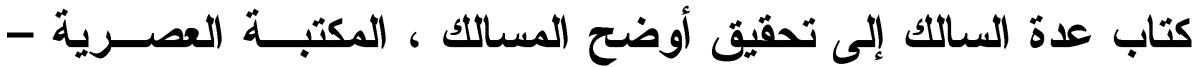

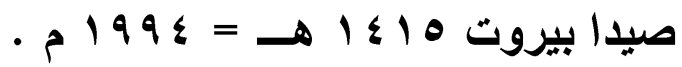

r ا البداية والنهاية : (بن كثير ، مكتبة المعارف - مصر .

rا البيان في غريب إعراب القرآن : ابن الأبلارى ، تحقيق : د . جــودة

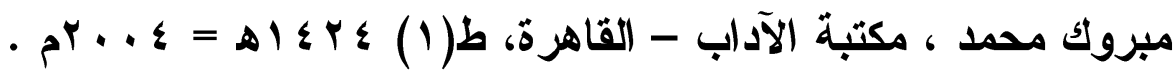

1 1) البحث اللغوى : د. محمود فهمى حجازى ، دار غريــب - القــاهرة ،

$$
\text { - } 199 \mathrm{~V}
$$

1 1) البحر المحيط : أبو حيان الألدلسى ، مطبعة السعادة - بجوار محافظة مصر ، طا(1) (1)

1 1) بداية المريد في فن التجويد : سيل مختار أبوشــادى ، مراجعــة : د. عبدالباسط هاشم ، الثيخ عبدالفتاح بيومى مدكور ، دار أعلام السلف

$$
\text { - القاهرة ط(r) }
$$

( البهجة المرضية في شرح الألفية : الســيوطى ، تحقيـق : د. أحمـــ

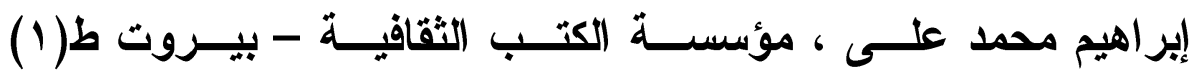

$$
\text { . } r . . .=\rightarrow 1 \leq r 1
$$




\section{الترقيم الدوله \\ ISSN 2356-9050}

11 ا) البرهان في علوم القرآن : الزركشى ، تحقيق : مصطقى عبــدالقادر

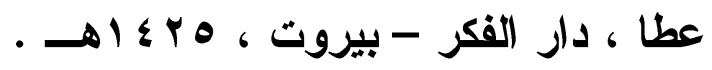

9 1) التمهيد في علم التجويد : ابن الجزرى ، مؤسسة قرطبة - القــاهرة ،

$$
\text { . }
$$

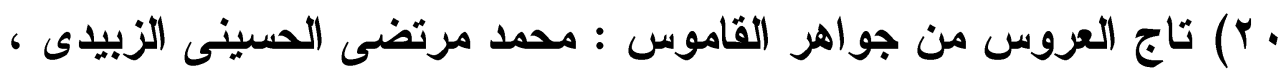

تحقيق : د . نواف الجراح ، مراجعة : د. سمير شمس ، دار صادر -

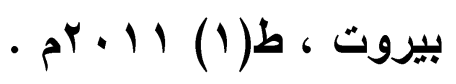

ا Y ) حجة القزاءات : ابن زنجلة ، تحقيق سعيد الأفغانى ، مؤسسة الرسالة

$$
\text { بيروت طان(0) }
$$

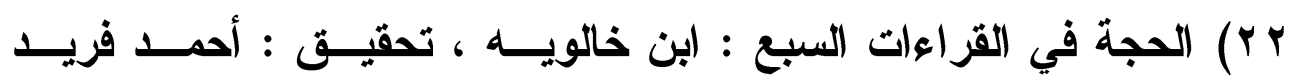

المزيلى ،تقديم : د ـ فتحى حجازى ، منشورات محمد على بيضون -

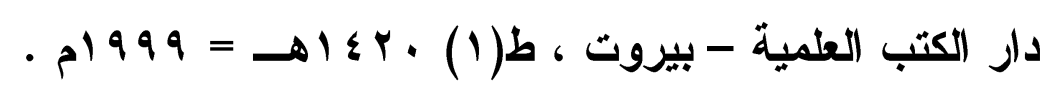

r r الخصائص : ابن جنى ، تحقيق : د . عبدالحميل هنداوى ، منشورات

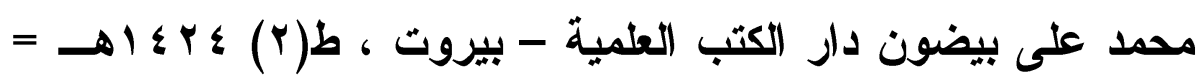

$$
\cdot r \cdot r
$$

ع r) الار المصون في علوم الكتاب المكنون: أحمد بن يوسـف المعـروف بالسمين الحلبي ، تحقيق د. أحمد محمد الخراط ،دار القلم - دمثث.

ه r) الار اسات الصوتية عند العلماء العرب والدرس الصوتى الحــديث : د. حسام البهنساوى ، زهر اء الثرق - القاهرة . 
مناقشة ابن جني (بrarهـ)

צY Y دراسات في علم الأصوات : د. صبرى المتــولى ، أجــازه د.شــوقى

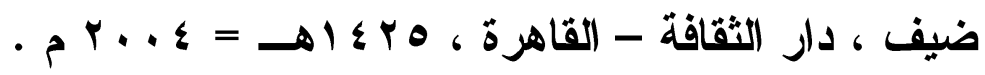

الارر الباهرة في توجيه القراءات العشر المتواترة : د. محمــد ســالم

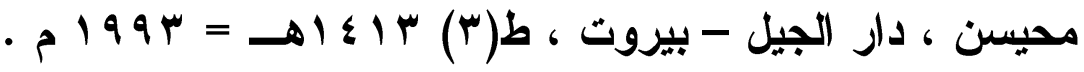

Y ا السبعة في القراعات : (بن مجاهد ، تحقيق : د. شوقى ضـيف ، دار

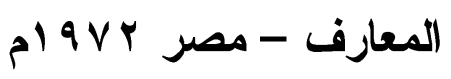

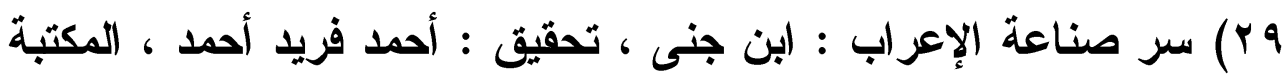

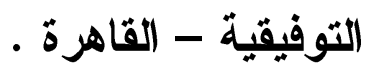

• ش) شذرات الذهب في أخبار من ذهب : (ابن العماد الحنبلى ، دار الفكر -

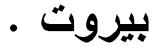

ابr) شرح ابن عقيل : (بن عقيل ، تحقيق : محمد محيى الاين عبدالحميد ،

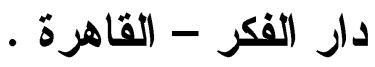

r r شرح التسهيل : ابن مالك ، تحقيق : أحمد السيد أحمد على ، المكتبة

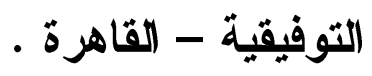

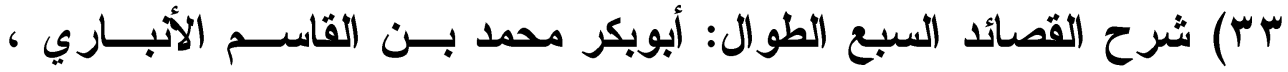

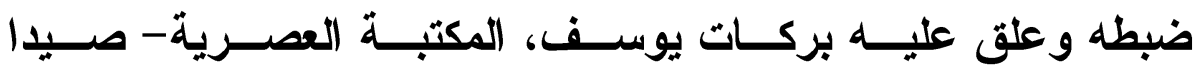

$$
\cdot{ }^{r} \cdot 11=-1 \leqslant r r
$$

ع "r) شرح المفصل : ابن يعيش ، تحقيق : د. إبراهيم محمد عبــدالله ، دار سعد الدين للطباعة والنشر - القاهرة . 


\section{الترقيم الدولم \\ ISSN 2356-9050}

هب) الصاحبى في فقه اللغة العربية : ابن فــارس ، تحقيـق : د ـ ـ عــر الطباع ، مكتبة المعارف - بيروت .

צr) الصحاح : الجوهرى ، دار إحياء التــراث العربـى - بيـروت ط(1) . p) $999=\rightarrow 1 \& 19$

صحيح مسلم بشرح النووى : تحقيق : عصام الصبابطى ، دار الحديث

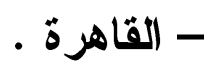

^r) الظواهر الصوتية والصرفية والنحوية في قراعة الجحدى البصرى :

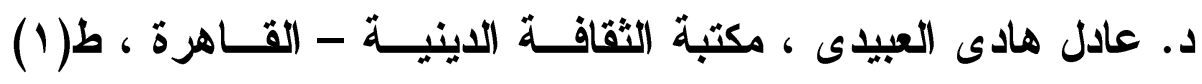

$$
\text { . مr. }
$$

q ب) العربية والوظائف النحويــة : د. دمــدوح الرمــالى ، دار المعرفــة

$$
\text { الجامعية - الإسكندرية ، } 999 \text { المولة }
$$

• ع) علم الأصوات : د. كمال بشر ، دار غريب- القاهرة .

اء) علم الالالة : د ـ أحمد مختار عمر ، عالم الكتب - القــاهرة ، ط(ه) - $) \wedge 9 \wedge$

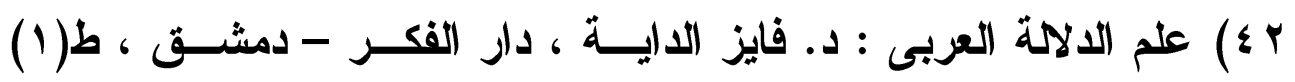

$$
\text { م) } 910=\rightarrow \mid \varepsilon \cdot 0
$$

بـ علم الدلامة والمعجم العربى : د. عبدالقادر أبو شريفة ، دار الفكـر عمان

؟ §) علم اللغةة مقدمة للقارئ العربى : د. محمــود الســعران ، دار الفكـر

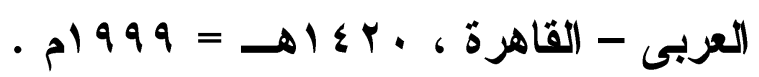


مناقشية ابن جني (عrara)

هـ غريب الحديث : أبو عبيد القاسم بن ســلام ، دار الكتـب العلميــة ـ

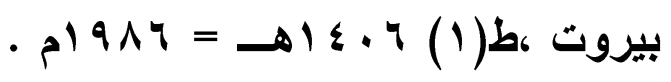

\ §) فقه اللغة وسر العربية : الثعالبى ، تحقيق : املين نسيب ، دار الجيل

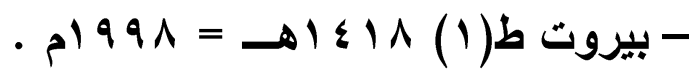

\& V الفهرست : (ابن النديم ، تحقيق : إبراهيم رمضــان ، دار المعرفــة -

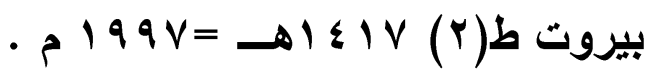

^ ـ) في اللهجات العربية : د ـ إبراهيم أنيس ، مكتبة الأنجلو المصـرية ،

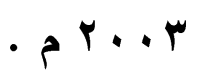

9 ؛) القاموس المحيط : الفيروزآبادى ، دار الكتـبـ (لعلميــة - بيـروت ،

$$
\text { . } 1999=-1 \leqslant 19(1)
$$

• (الكتاب : سيبويه ، تحقيق : عبدالسلام هارون ، مكتبـة الخــاتجى -

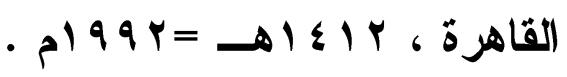

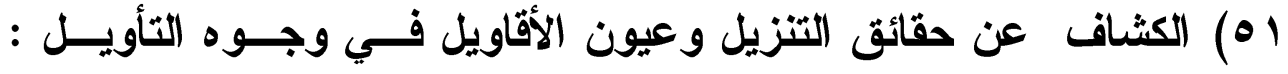

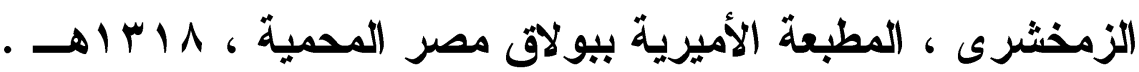

$$
\text { roro لسان العرب : (بن منظور ، دار المعارف - القاهرة . }
$$

به) اللغة بين العقل والمغامرة : د. مصطفى مندور منثــأة المعــارف -

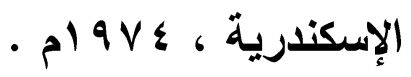

؛ ه) لغة تميم ، دراسة تاريخية وصفية : د. ضاحي عبــدالباقي ، الهيئــة

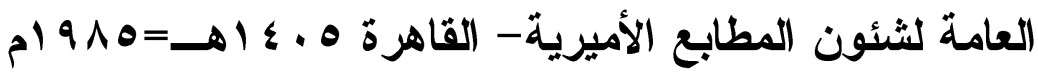




\section{الترقيم الدوله \\ ISSN 2356-9050}

هـ) اللهجات العربية نشأة وتطورا : د. عبدالغفار حامد هلا ، مكتبة وهبة

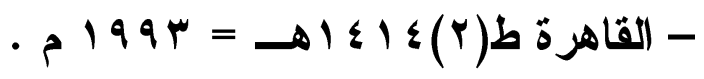

צه) اللهجات العربية في التراث : د. أحمد علم الجندى ، الــــار العربيــة لاكتاب - تونس 9 ام

OV اللهجات في الكتاب لسيبويه ، أصواتا وبنيــة: د. صـالحة راثــــ آل غنيم، رسالة ماجستير بجامعسـة أم القــرى - مكــة المكرمــة، ط(1)

$$
\text { . ) } 9 \wedge 0=\rightarrow 1 \varepsilon .0
$$

Aه) مجالس ثُعلب شرح وتحقيق عبدالسلام محمد هارون ، دار المعارف -

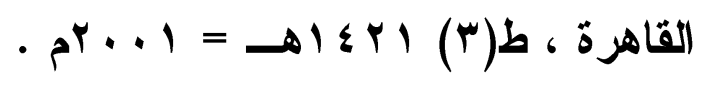

9ه) المحتسب في تبيين وجوه شواذ القراعات والإيضاح عنها : ابن جنى ، تحقيق : محمد عبدالقادر عطا ، منشورات محمد على بيضــون ، دار

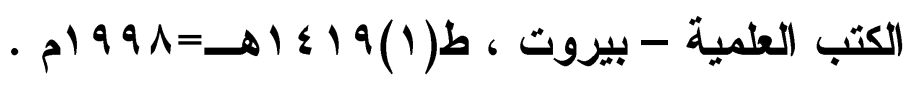

ـ 7) المدخل إلى علم اللغة : د . رمضان عبدالتواب ، الخانجى - القاهرة ،

$$
\text { - } 191 \text {. }
$$

آ) المدخل إلى علم اللغة ومناهج البحث اللغـوى : د. محمـود فهــى

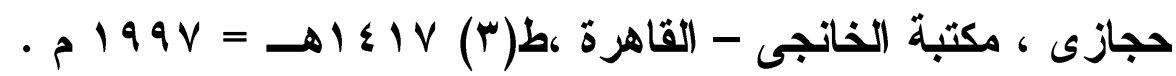

ץ 7) مسند الإمام أحمد : تحقيق : أحمد محمـــ شــاكر ، دار المعــــ -

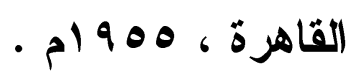

با7) مشكلة الههزة العربية : د. رمضان عبدالتواب ، مكتبــة الخــاتجى -

$$
\text { القاهرة كطا(1) (1) }
$$


مناقشة ابن جني (بrar)

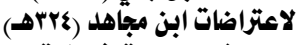

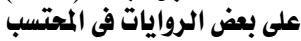

ـ 7) معالم اللهجات العزبية : د. عبدالحميد أبو سكين ، كلية اللغة العربيــة

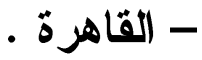

ه 7) معانى القر آن للأخفش ( سعيد بن مسعدة ) : تحقيق : د. عبــدالأمير

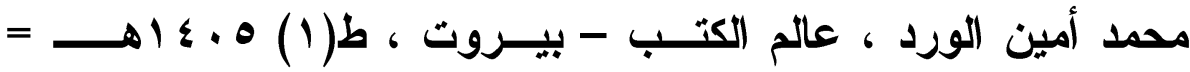

$$
\text { - } 1910
$$

7 7) معانى القراعات : الأزهرى ، تحقيق : أحمد فريد المزيدى ، تقديم : د. فتحى عبدالرحمن حجازى ، منشورات محمد على بيضون -ـار الكتب

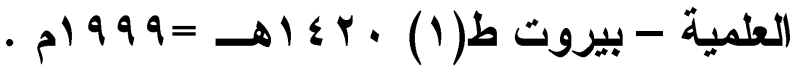

7V) معانى القرآن : القراء ، تحقيق : أ.د صلاح عبــدالعزيز السـيد و د. محمد مصطفى الطيب ، ود. عبدالعزيز محمــد فــاخر ، دار الســلام

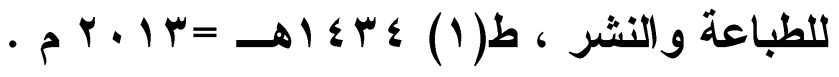

1 1) المغنى في توجيه القراعات العشر المتواترة : د. محمد سالم محيسن ،

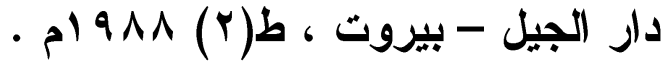

97) مغنى اللبيب عن كتب الأعاريب : تحقيق : ح الفاخورى ، دار الجيل -

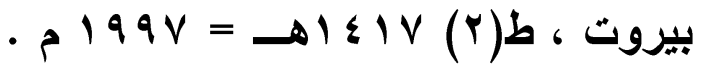

م مفاتيع الغيب : الفخر الرازى ، المطبعة الحسينية المصرية . المفردات في غريب القرآن : الر اغب الأصفهانى ، المطبعة الميمينة ،

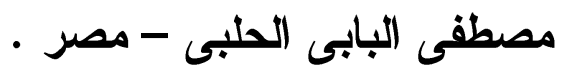

( المنهاج في القواعد والإعراب : محمد الأطظاكى ، تحقيق : سمير إبــراهيم

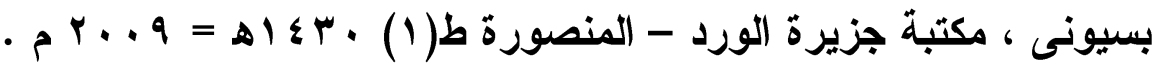

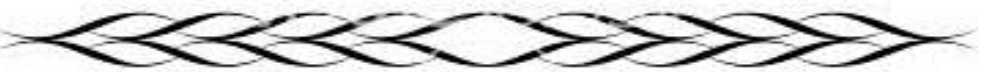




\section{الترقيم الدولم \\ ISSN 2356-9050}

Vr موسيقى الشعر بين الاتباع والابتداع : د. شعبان صلاح ، دار الثقافة

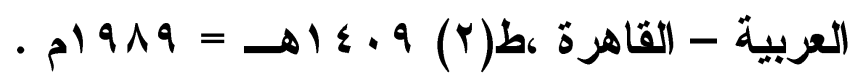

ع النشر في القراعات العشر : ابن الجزرى ، تقديم : على محمد الطباع ، خرج آياته : زكريا عميرات ، منشورات محمد على بيضــون ، دار

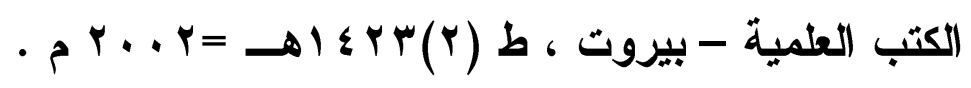

ه V) النهاية في غريب الحديث والأثر : (بن الأثير ، تحقيـق : د. محمــود

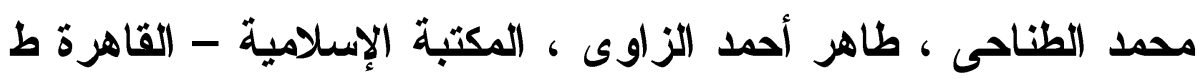

$$
\begin{aligned}
& \text {. } 9 \text { ا } 9 \text { r = } \\
& \text { الرسائل الجامهية }
\end{aligned}
$$

1- البحث اللغوى عند الأصوليين : د. محمد عادل خلف ، رسالة ماجتسيز

$$
\text { آداب المنيا }
$$

r- البحث الالالى عند ابن حزم الألدلسى : د. أحمد إبراهيم محمد علــى ، رسالة دكتور اه - جامعة المنيا ، . . . بم .

\section{المراجع الأجنبية}

- The study of language, an introduction, G.yule , combridge university press, Britain , 1987. 


\begin{tabular}{|c|c|c|}
\hline \multicolumn{2}{|c|}{ 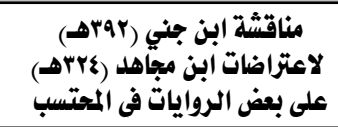 } & 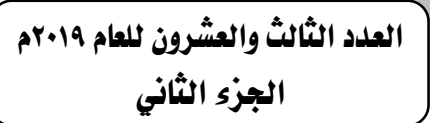 \\
\hline |لصفمة & & \multirow[t]{2}{*}{ الأوضوع } \\
\hline 1111 & & \\
\hline $111 \%$ & \multicolumn{2}{|c|}{$\underline{\text { Research Summary }}$} \\
\hline 1110 & & \\
\hline 1111 & \multicolumn{2}{|c|}{ التمههيد : ابن هجاهد وابن جنى } \\
\hline $11 r r$ & & ث \\
\hline IIr & & تقى \\
\hline 119 & & إي الصرفى \\
\hline 1119 & & وى النصوى \\
\hline 1419 & & 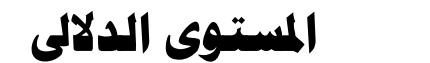 \\
\hline 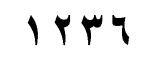 & & \\
\hline Irq & & المسادر والمراجع \\
\hline $1 Y \varepsilon V$ & & الإعضوعات \\
\hline
\end{tabular}

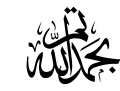

